\title{
E-BOOK AMPLAMENTE
}

EDUCAÇAO NA CONTEMPORANETDADE

Organizadores

Luciano Luan Comes Paiva

Dayana Lúcia Rodrigues de Freitas

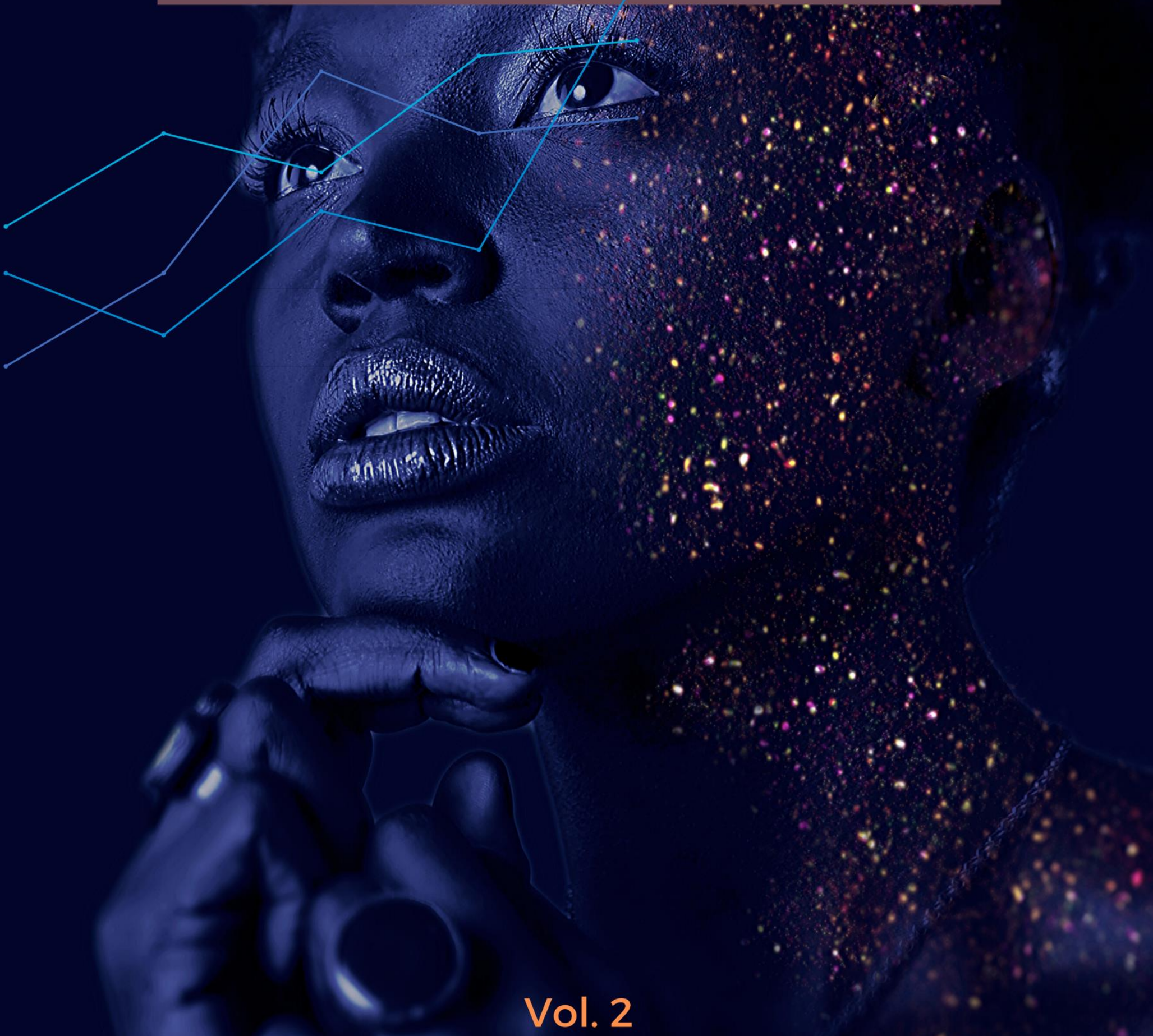


E-BOOK

\title{
AMPLAMENTE: EDUCAÇÃO NA CONTEMPORANEIDADE $1^{a}$ edição. Volume 02.
}

\author{
ORGANIZADORES \\ Luciano Luan Gomes Paiva \\ Dayana Lúcia Rodrigues de Freitas
}

COLABORADORA

Caroline Rodrigues de Freitas Fernandes

\section{AMPLAMENTE CURSOS}

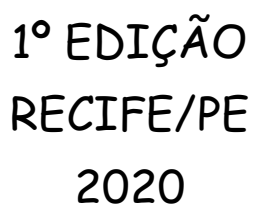

$10.29327 / 514087$

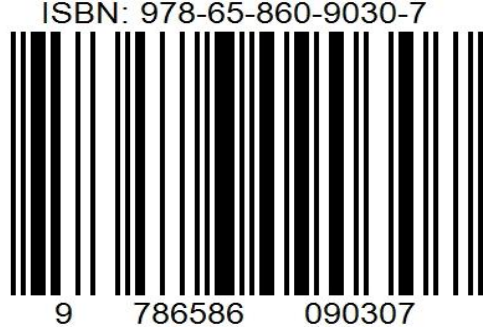


Dados Internacionais de Catalogação na Publicação (CIP) (Even3 Publicações, PE, Brasil)

A526 Amplamente: Educação na Contemporaneidade / Luciano Luan Gomes Paiva e Dayana Lucia Rodrigues de Freitas. - Vol 2 - 1. ed. - Recife: Even3 Publicações, 2020.

1 livro digital ; $289 \mathrm{p}$.

Bibliografia.

ISBN: 978-65-86090-30-7

DOI: $10.29327 / 514087$

1. Educação. 2. Formação de Professores. 3. Pesquisa em Educação.

I. Título 


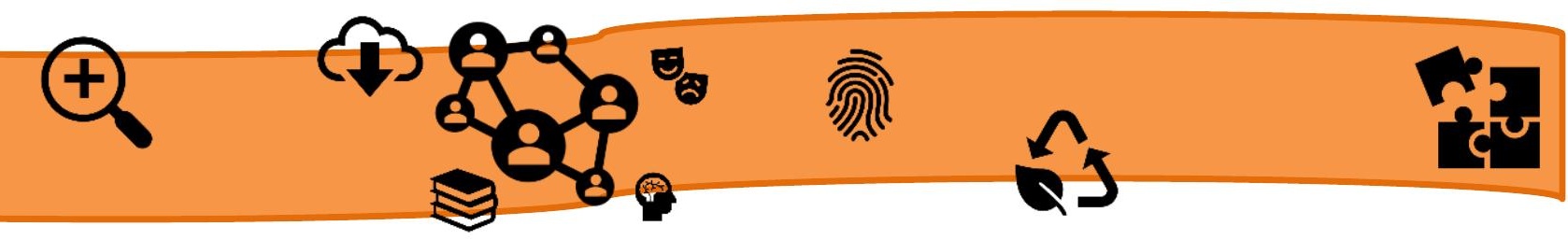

OAmplamente Cursos e Formação Continuada

$1^{a}$ edição. Volume 02. (E-BOOK)

\author{
Capa/Projeto gráfico \\ Luciano Luan Gomes Paiva \\ Dayana Lúcia Rodrigues de Freitas
}

\title{
E-BOOK (online)
}

Este e-book possui textos nacionais e internacionais. Todos os direitos reservados. Partes desta obra podem ser utilizadas ou reproduzidas desde que sejam devidamente citadas e referenciadas. Cada autor é inteiramente responsável por seu(s) respectivo(s) texto(s), isentando a Amplamente Cursos e Formação Continuada de qualquer problema ou erro.

Editado por: Amplamente Cursos e Formação Continuada

ISBN: 978-65-860-9030-7

$10.29327 / 514087$

Amplamente Cursos e Formação Continuada

CNPJ: $35.719 .570 / 0001-10$

Tel.: (84) 99707-2900 



intensa disparidade contextual, convergem para um caminho: pensar a Educação atual para construir um futuro melhor e pensar nas gerações futuras para construir uma Educação na Contemporaneidade.

Assim, em nome da Amplamente Cursos e Formação Continuada, convido a todos para leitura no debate científico da Educação na Contemporaneidade, com propostas, apontamentos, análises, reflexões entre outras questões pertinentes para conter neste material e para 0 campo educacional. Boa leitura! 
$\mathrm{Na}$ era da globalização, em que as informações chegam de forma muito rápida por meio da televisão, do cinema, do rádio, do vídeo, do computador, o trabalho pedagógico do professor enriquecer-se-á se ele utilizar todos esses recursos para a produção de um conhecimento que ajude o aluno a compreender o mundo que vive (PONTUSCHKA et. al., 2009).

A perda de interesse na participação dos alunos no desenvolvimento da disciplina de geografia, também se faz pelo fato de que o professor, segundo a visão dos alunos, ainda têm concepções utilizadas em métodos tradicionais na forma de desenvolver a disciplina, que é sustentada por uma lógica em que o professor é considerado quem tem mais facilidade em entender sobre a disciplina. Ainda tem como postura uma aula fragmentada e com conhecimentos em que os conteúdos na estruturação curricular é rígida e as estratégias, sem novidades, monótona, o que deixam as aulas mais chatas, repetitivas, sem nada que desperte os alunos a entenderem e se interessarem.

Os Parâmetros Curriculares Nacionais - PCNs, documento muito importante no desenvolvimento da aprendizagem, diz que na disciplina de geografia, em seu desenvolvimento, o jeito que uma grande maioria dos professores se prende a muitos livros didáticos, esses mesmos conservam ainda a linha tradicional, descritiva e despolitizada, herdada da Geografia Tradicional. O que se criou uma contradição entre o discurso do professor e o conteúdo dos livros de Geografia, que se convencionou chamar de crítica, por ter sido marcada por um discurso retórico. (BRASIL, 1998).

No entanto, infelizmente, essa falta de vontade de mudar as estratégias por parte dos professores, quem perde sempre são os alunos por conta de não conseguir ter um melhor entendimento. O professor, infelizmente, ainda acreditava que tem que ser do jeito tradicional, sem abertura para questionamentos, alegando que através de métodos mais tradicionais sempre funcionou, que se não for assim não terá sentido, a seriedade do ensino da disciplina de geografia, podendo virar bagunças e mais indisciplina.

Desta forma, uma das justificativas do presente artigo é desenvolver possibilidades de intervenção pedagógica pautada na disciplina de geografia, diante dos desafios que são vivenciados e expressos pelos alunos que têm muitas dificuldades em aprender, têm comportamento agitado e questionador. Dentre tantas situações conflituosas, nesta aprendizagem foi utilizado materiais e métodos, tendo como 


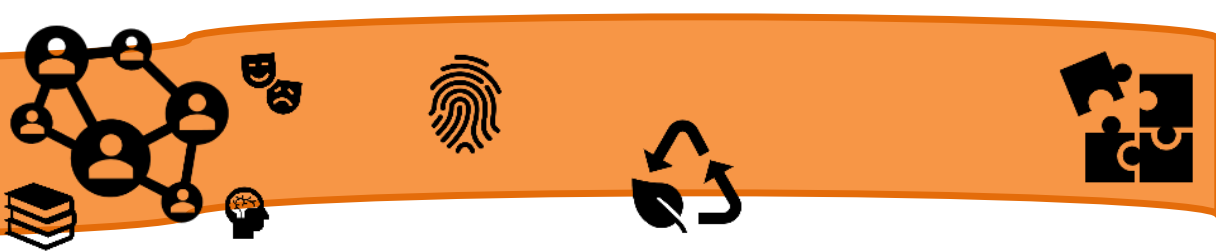

estratégias, pesquisa de caráter bibliográfico, transitando entre ideias de autores contemporâneos específicos da área de geografia.

Segundo Cavalcanti (2011), um ensino que centra suas ações na busca de uma aprendizagem significativa dos alunos deve ter como ponto básico o conhecimento dos próprios alunos, pois, considerando as contribuições dos psicólogos da linha vigotskiana, essa aprendizagem só ocorre num processo de formação inter e intrassubjetivo, no qual o sujeito (aluno) é ativo e possuidor de conhecimentos.

Possuir como intuito a reflexão e revisão dos professores, e com isso compreender a importância do desenvolvimento da disciplina Geografia durante as aulas, é importante que tenham olhares novos, visando oportunidades e possibilidades de rever a realidade, tal situação que configura e agrega as visões do mundo enquanto sociedade.

O uso de toda uma gama de ferramentas dentro do contexto de sala de aula objetiva a um entrar a motivação, tanto de professores quanto de alunos, já que possibilita uma interação diferenciada, mais constante, na medida em que amplia as possibilidades de contato entre educandos e educadores, não mais restrito apenas ao ambiente escolar (TEIXEIRA, 2011).

No Brasil, por exemplo, observado como espaço geográfico encontra-se em constante transformação às propostas curriculares, que também precisam ser modificadas pensando no que ensinar e como ensinar. Para alunos, sendo membros participativos e importantes em nossa sociedade, então, neste contexto, as abordagens, conteúdos, métodos e metodologias do ensino desta ciência/disciplina escolar necessitam de uma constante readequação, que favoreça aos alunos e aos desafios que se apresentam hoje na prática pedagógica, para que sejam elencadas, com uma melhora significativa no conhecimento da disciplina de geografia.

O caminho para construção do conhecimento, no aluno, ao formular seus conceitos, vai fazê-lo, operando com os conceitos do cotidiano e os conceitos científicos. Em geral, todos os temos conceitos formulados a respeito das coisas, e a tarefa da escola é favorecer a reformulação dos conceitos originários do senso comum em conceitos científicos. "[...] A construção dos conceitos ocorre pela prática diária, pela observação, pelas experiências, pelo fazer” (CALLAI, 2009, p. 103). 


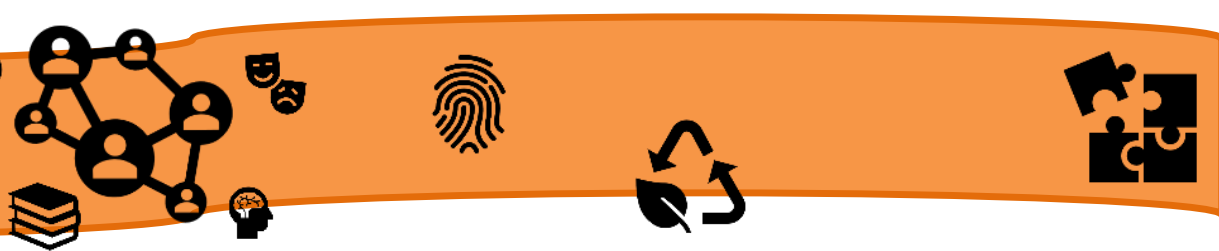

Assim, é apresentada uma breve discussão que convida a todos a refletirem sobre seu exercício e sua ação, tanto na escola quanto na sociedade. Desta maneira serão apresentados, neste artigo, situações que abordam como a Geografia chegou ao ensino brasileiro, quais eram seus objetivos assim como obstáculos, que a disciplina vivenciou para que tivesse seu espaço e agregar no conhecimento dos alunos. Não deixando de mencionar aqui que a disciplina de geografia, a qual sua prática no Brasil, era apenas para alunos considerados da elite.

Será apontado também quais foram os desafios que a disciplina de geografia ainda encontra, em dias atuais, para chamar a atenção dos alunos para a aprendizagem e dos professores que ministram essas aulas, em que muitas vezes se sentem frente a diversos desafios, frustração e desânimo. Finalizo o artigo destacando as possibilidades de novas estratégias possíveis na tarefa de educar e ensinar com sucesso e retorno efetivo de aprendizagem nesta disciplina a geografia.

\section{A ENTRADA DA DISCIPLINA DE GEOGRAFIA NAS ESCOLAS DO BRASIL}

A geografia passou a ser difundida em um contexto mundial como ciência e disciplina escolar a partir do século XVIII, na antiga Grécia, porém sua entrada aqui no Brasil ocorreu em 1837, no Colégio Pedro II. Enquanto disciplina, era voltada para um caráter descritivo e com o objetivo de criar uma identidade nacional, que acabara de ficar independente, tanto que, enquanto componente curricular, o objetivo da disciplina de geografia era ensinar cultura básica, exclusivamente para alunos com alto poder aquisitivo, que tinham condições de conhecer melhor nosso pais. Para tanto, os primeiros professores que podiam ministrar a disciplina de geografia eram pessoas de outras profissões, como advogados, sacerdotes ou autodidatas.

Segundo Cassab (2009), a geografia passa a ganhar uma nova dimensão no Brasil apenas na década de 30, quando foi fundado o Curso Livre de Geografia. Todavia, a disciplina de Geografia no em território brasileiro, foi formalizada como nível superior em anos subsequente se organiza com a fundação da AGB (Associação de Geógrafos Brasileiros) em 1935, e o Conselho Nacional de Geografia em 1937 e o IBGE (Instituto Brasileiro de Geografia e Estatística) em 1939. Nesta época, de 1940 a 1970, que os primeiros livros didáticos da disciplina de Geografia começaram a ser publicados no Brasil. 


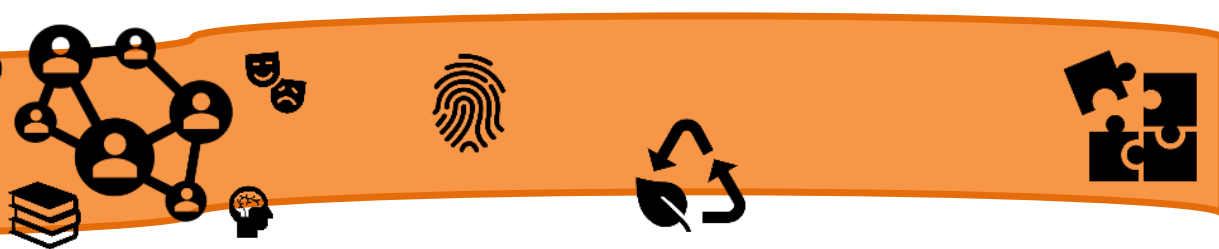

Com a organização e mudança, a disciplina de Geografia, de fato ganhou seu espaço, com estudos mais específicos para que pudesse ser compreendida, mas não durou muito, pois em 1964, houve um golpe político e a disciplina de geografia foi usada como uma técnica ideológica, a qual teve grande interferência para a população civil.

Segundo Cavalcanti (2006), cabe reafirmar e explicitar a importância da Geografia escolar para a formação geral de cidadãos. Na relação cognitiva de crianças, jovens e adultos com o mundo, o raciocínio espacial é necessário, pois as práticas sociais cotidianas têm uma dimensão espacial. Os alunos que estudam essa disciplina já possuem conhecimentos nessa área, oriundos de sua relação direta e cotidiana com o espaço vivido.

Sendo assim, o trabalho de educação geográfica é o de ajudar os alunos a analisarem esses conhecimentos, a desenvolverem modos de pensamento geográfico a internalizarem métodos e procedimentos, de captar a realidade vivida e "apresentada" pela geografia escolar, tendo consciência de sua espacialidade. Esse modo de pensar geográfico é importante para a realização de práticas sociais variadas, já que essas práticas são sempre práticas socioespaciais (CAVALCANTI, 2006).

Na década de 1980, a disciplina de Geografia, sendo mais bem observada no Brasil, conseguiu ampliar o nível e o ensino atingindo em nível superior, teses de mestrado, doutorado em Universidades. No entanto, o foco ainda estava na economia e organização (delimitação) espacial em sociedade, que deu um valor a paisagem do país enquanto território brasileiro.

Cassab (2009) afirma que: na educação escolar, a Geografia se restringia ao estudo das paisagens naturais e humanizadas, além de estratégias didáticas pautadas na memorização dos lugares e de seus elementos. Ao aluno cabia descrever e relacionar os fatos naturais e sociais, fazer analogias entre eles e elaborar suas generalizações ou sínteses. O propósito era ensinar uma Geografia científica, na época sinônimo de neutra (CASSAB, 2009).

Com entrada da Geografia crítica no Brasil, ela afetou muito enquanto disciplina e enquanto ensino, porque a metodologia utilizada era puramente vinculada a correntes, envolvendo teorias qualitativas. Por ser decorativa e que não tinha compreensão dos 


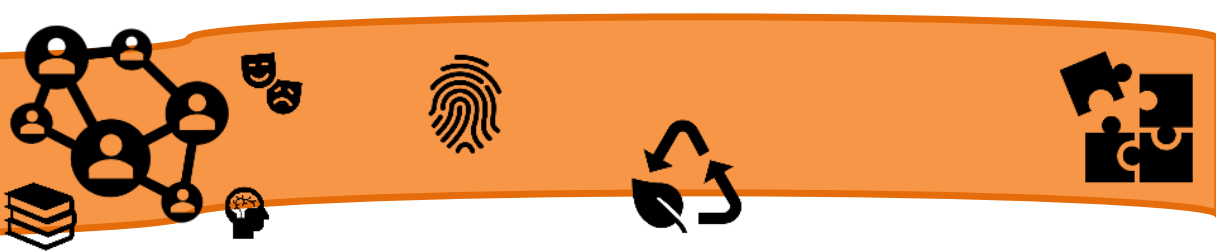

alunos, não que fossem conteúdos ruins, mas a forma como era desenvolvida, deixavam a disciplina e seu ensino com pouco sentido e conhecimento.

Para tanto, que nos anos 80 foi revisada novamente, quanto à compreensão e aprendizagem dos assuntos, que a disciplina disponibiliza com isso a chegada da corrente humanista, por meados de 1990. Esta aprendizagem ganhou maior significado, pois se tinha a preocupação de inserir o aluno ao conhecimento dentro da disciplina de geografia, estudos e aprendizagens que envolviam também o local onde o aluno morava, assim como fatos diários. Santos (2008) afirma que:

[...] algo dinâmico e unitário, onde se reúnem materialidade e ação humana. O espaço seria o conjunto indissociável de sistemas de objetos, naturais ou fabricados, e de sistemas de ações, deliberadas ou não. A cada época, novos objetos e novas ações vêm juntar-se às outras, modificando o todo, tanto formal quanto substancialmente. (SANTOS, 2008, p. 46).

Nos anos 90, com implantação da política neoliberal, a elaboração da Leis de Diretrizes e Bases - LDB, formalizou-se em 1996, proporcionando com objetivos, novas diretrizes na educação nacional, estipulando um Sistema Nacional de Educação, o que não foi apenas uma Organização na Educação nacional, mas a união de sistemas educacionais em documentos, sendo o mesmo de caráter mais investigativo e pesquisado dentro da politica neoliberal, em que propósito da aprendizagem fossem atingidos pelos alunos.

Propósitos esses que, estabelecidos juntamente com órgãos internacionais, como a UNESCO, Banco Mundial, os quais se vincularam também para que a Educação pudesse ser avaliada, também com avaliações da economia mundial.

Mediante esse avanço na organização da educação, a LDB (Lei de Diretrizes e Bases), elaborou em 1996, os PCNs, sendo esse documento com o objetivo de organizar, o ensino aprendizagem da Geografia nas escolas, baseado na realidade do aluno, enquanto seu cotidiano. Para isso, os PCNs, estipulam eixos temáticos, o que proporcionou para os professores desenvolver com os alunos, metodologias e estratégias e interdisciplinares dentro dos conteúdos da disciplina de geografia.

Segundo PCNS (1998), é fundamental que o professor crie e planeje situações de aprendizagem em que os alunos possam conhecer e utilizar os procedimentos de estudos geográficos. A observação, descrição, analogia e síntese são procedimentos importantes 
e podem ser praticados com alunos. Eles podem aprender a explicar, compreender e representar os processos de construção dos diferentes tipos de paisagens, territórios e lugares. Isso não significa que os procedimentos tenham uns fins em si mesmos: observar, descrever e comparar servem para construir noções, especializar os fenômenos, levantar problemas e compreender as soluções propostas. Enfim, para conhecer e começar a operar os conhecimentos que a Geografia, como ciência, produz (PCN, 1998, p. 30).

\section{DIFICULDADES E DESAFIOS DE MINISTRAR GEOGRAFIA}

Dentro da Educação brasileira, as transformações são explícitas, assim como infinitas mudanças, sendo algumas necessárias, outras nem tanto que, comparados aos modelos de anos anteriores, deixa espaço de dúvidas, conflitos e desafios que giram em torno de faltas de estratégias o desenvolvimento das aulas. Por que os alunos perdem o interesse em frequentar as aulas, banalizando a disciplina? Por conta de tantas situações desestimulantes, o professor se sente desmotivado e desvalorizado.

Cavalcanti (1998) afirma que, por décadas, o ensino da Geografia Escolar tinha como objetivo simplesmente a transmissão do conhecimento já elaborado e o consentimento da massa populacional subordinada às formas de organização social impostas. Esta última voltada para o conhecimento, amor e defesa do Estado-nação. O espaço geográfico era visto como homogêneo, não-contraditório e sem crises. No ensino tradicional da geografia, cabia ao aluno apenas a memorização de informações, e os conteúdos eram "veiculados como verdades absolutas, principalmente, através de aulas expositivas, nas quais o professor era o detentor do conhecimento e o aluno o receptor deste" (CARVALHO, 1998, p. 27).

Como na disciplina de Geografia, o método tradicional o qual era seguido com afinco, por parte dos professores, o maior foco em anos anteriores se resumia em decorar as informações e as mesmas serem devolvidas pelo aluno, do jeito em que se encontrava em livros didáticos escolhidos por esses professores, junto com a equipe gestora. Infelizmente, não tinham preocupação em trazer para o cotidiano do aluno essa diversidade de informações, formando uma bola de neve e um desafio difícil de encontrar solução, pois assim era devolutiva dos professores quando questionados sobre 
as estratégias utilizadas na sala de aula. Esse professor atrelava esta falta de interesse dos alunos à indisciplina e falta de atenção dos alunos.

O que ocorreu e perdurou durante anos no ensino aprendizagem dos alunos na disciplina de Geografia, foi à educação bancária citada por Paulo Freire (2005), pois essas informações eram transmitidas para os alunos, os quais não tinham oportunidade de questionamento por já está tudo pronto e os alunos não conseguiam relacionar essas informações com seu cotidiano.

Desta forma, a geografia foi marcada como uma disciplina preocupada em fazer os mapas, decorar os estados, quanto a localização, vegetação dentre outras informações. Para os alunos não serviriam para muita coisa em seu aprendizado, pois as locas apresentadas nesses livros, ora eram com paisagens maravilhosas, em outros casos lugares extremamente, mal conservados.

Segundo Brito e Pessoa (2009):

Em geral, se compreende, até mesmo por falta de um debate mais sistemático sobre o tema geografia praticado nos níveis fundamental e médio é apenas uma mera e simples repetição simplificada na academia. [...] Logo a geografia crítica dá importância à realidade do estudante, as suas experiências, a sua condição de vida, aos seus conflitos e interesses produzidos no tempo e no espaço, se preocupa em formar estudantes-cidadãos, ativos e participativos, desenvolvendo neles criticidade, autonomia e criatividade em face aos problemas encontrados no seu cotidiano e no seu espaço de vivência (BRITO; PESSOA, 2009, p. 6-7).

Logo, a geografia crítica dá importância à realidade do estudante, às suas experiências, à sua condição de vida, aos seus conflitos e interesses produzidos no tempo e no espaço, se preocupa em formar estudantes-cidadãos, ativos e participativos, desenvolvendo conteúdos abordados em geografia. Eram considerados como fora da realidade do aluno, que se tornou outro desafio, que provocou essa situação, entre professor, aluno e disciplina.

Contrariando ao desejo de aprendizagem o qual se almejava, que era a aprendizagem, os alunos foram sendo induzidos para formar cidadãos reprodutores de uma sociedade que não tinham opiniões e sequer chance de conhecer às paisagens bacanas, o que beneficiava apenas a pequena minoria de classes econômicas com maiores poder aquisitivo. 


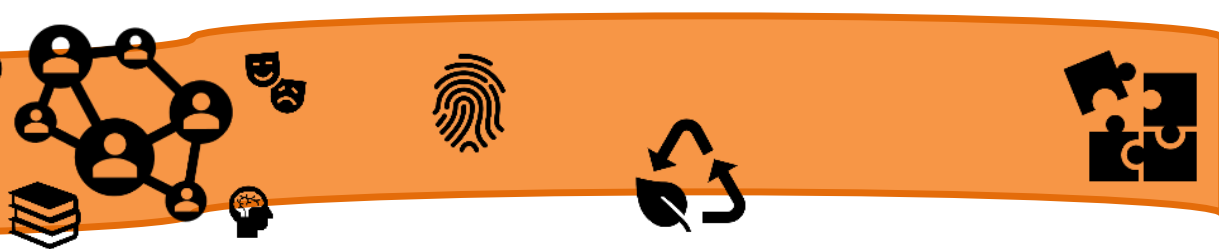

Desta forma a geografia ficou reconhecida como uma disciplina que envolvia quadro, giz, livro de anotações e apreciação das paisagens naturais desenvolvidas em livros didáticos, que na visão dos alunos, era inatingível. Dentro da realidade em que se encontravam, temos claro que manter um aluno, com disciplina em uma aula que estava longe da história social, aumentando o fluxo de alunos desatentos, indisciplinados e com muitas notas baixas foi o resultado mais provável, quando não, o abandono dos estudos não só por esses motivos, mas por reprovação em não entender o porquê aprender uma disciplina a qual não fazia parte de sua realidade.

Contudo, por meados dos séculos XX, início do século XXI, a Geografia teve outras mudanças, as quais foram reformulados de maneira mais peculiar e especial $o$ desenvolvimento das aulas de geografia, o que permitiu uma nova fase, dando mais espaços para que novas estratégias fossem utilizadas no ensino da disciplina de geografia em sala de aula.

A partir dessas propostas de rever as estratégias e métodos utilizados permeou entre os professores vários questionamentos, como chamar a atenção de alunos em sala de aula, sendo que esses alunos não possuíam subsídios plausíveis, a não ser os livros didáticos e mais, muitos professores não tinham sequer habilidades com as tecnologias. Como de um a hora para outra, repensar algo que já tinham planejado e utilizavam durante anos com alunos, e acreditavam estar a contentes?

A globalização foi entendida como algo que tinha seus pontos negativos e positivos em relação à aprendizagem de geografia, a ponto de muitos professores rejeitaram os planos que eram apresentados e que poderia ser uma nova estratégia para conquistar os alunos em sala de sala. Por conta de ser um leque de possibilidades, que poderiam ser usados para melhoria da aprendizagem, este é um dos pontos positivos, porém como negativo, o descarte das explicações dos professores, banalização das aulas e falta de condições por conta de materiais tecnológicos nas instituições, em especial escolas populares. Até o básico como livros didáticos já estavam difíceis de ser distribuídos aos alunos, quem diria oportunizar aos alunos o uso de computadores, assim eram o pensamento desses professores.

O desafio do ensino de geografia foi muito rejeitado, por causa do método tradicional, baseado em livros didáticos, que os professores alegavam ser o mais concreto por conta de ilustrações e exemplos, os quais manipulados os aluno a 
aprendizagem que esses livros eram autorizados a desvendar, a partir do momento em que as tecnologias utilizadas na globalização entram em cena, com exemplos de fatos da atualidade que eram disponibilizados mundialmente, colocavam o aluno em contato com situações conflituosas, quanto a reflexão por soluções para os contratempos. Cavalcanti (2002, p. 101) afirma que:

\begin{abstract}
Deve levar em conta as transformações pelas quais o mundo tem passado, transformações essas que são econômicas, políticas, sociais, espaciais, éticas, que provocaram alterações no que diz respeito ao mundo do trabalho e da formação do geógrafo e que afetam a formação profissional, as escolas, a identidade dos profissionais. Pensar a formação desse profissional implica considerar a sociedade contemporânea, marcada por essas transformações.
\end{abstract}

Ainda com tantos desafios descritos anteriormente na didática escolar na disciplina de Geografia teve sua estafa, que se apresentou e ainda nos dias de hoje é possível ser identificado de diversas formas, desde a organização espacial, para que os alunos tenham salas de aula equipadas, chamativas, assim como materiais disponíveis para que esses alunos possam manusear. Percebendo que vai além de mapa, quadro, giz, caderno folha de papel vegetal, entre outros simples materiais, mas computadores que possam funcionar, para o auxílio dessa aprendizagem, sendo um recurso estratégico para que o professor também tenha satisfação de uma aula interessante e com sucesso.

Segundo Morais (1994), a descrição, a enumeração e classificação dos fatos referentes ao espaço são momentos de sua apreensão, mas a Geografia Tradicional se limitou a eles; como se eles cumprissem toda a tarefa de um trabalho científico. E, desta forma, comprometeu estes próprios procedimentos, ora fazendo relações entre elementos de qualidade distinta, ora ignorando mediações e grandezas entre processos, ora formulando juízos genéricos apressados. E sempre concluindo com a elaboração de tipos formais, a-históricos e, enquanto tais, abstratos.

Esta concepção, presente em todas as definições apresentadas, emperrou a possibilidade de chegar à Geografia um conhecimento mais generalizador, que não fosse à custa do formalismo tipológico. Enfim, de que ele ultrapasse a descrição e classificação dos fenômenos (MORAES, 1994, p. 40)

Dentro da escola atualmente, o que se presencia ainda é uma labuta, por conta da evasão escolar, a preocupação de manter esse aluno matriculado, presente nas 


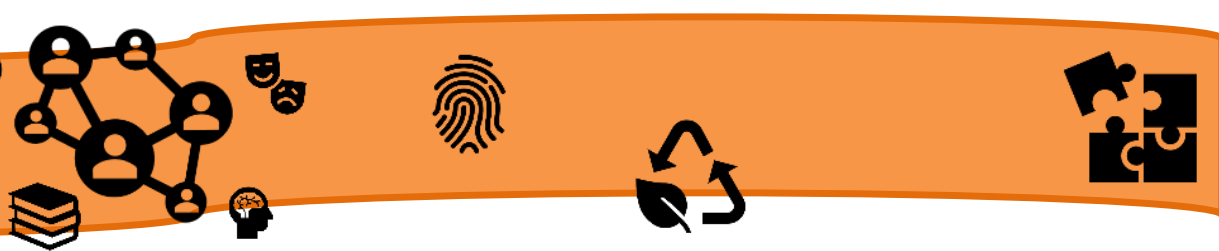

atividades, participativo e interessado, mas e o professor? Por que a cobrança por busca de aulas fantásticas é exigida? Por que não investir na formação contínua deste professor? Em que condições esse professor consegue desenvolver suas aulas, tendo o mesmo que atingir metas, sem a preocupação com reciclagem que auxilia melhores condições de desenvolver uma boa aula e com qualidade?

Cavalcanti (2002) aponta como referências, princípios que devem orientar a reforma curricular da formação profissional do geógrafo. Entre elas estão a Formação contínua e a Autoformação; a Indissociabilidade entre Pesquisa e Ensino; a Integração Teoria e Prática; a Formação e Profissionalização e o Conhecimento Integrado e a abordagem Interdisciplinar.

Para que o atendimento aos alunos em âmbito escolar ocorra com sucesso, também deve ser apontado o desafio de investir na formação dos Professores, pois se torna ponto crucial, para que esse aluno, a partir do fortalecimento ao professor com formações contínuas para que eles possam também expressar suas frustrações e desânimo. Tornar o desafio na possibilidade de reformular a disciplina, melhorando o desenvolvimento das aulas, pois novas estratégias são repensadas em conjunto com ações que podem ser viáveis para que a evasão diminua e a Educação ganhe seu significado verdadeiro que é o conhecimento e melhora na aprendizagem dos alunos, satisfação do professor em estar na sala de aula.

Educador e educando (liderança e massas), co-intencionados à realidade, se encontram numa tarefa em que ambos são sujeitos no ato, não só de revelá-la e, assim, criticamente conhecê-la, mas também no de recriar este conhecimento. (FREIRE, 2005, p. 64).

\section{A TAREFA DE ENSINAR COM NOVAS POSSIBILIDADES NA DISCIPLINA DE GEOGRAFIA}

É grande o conhecimento de que os professores têm como tarefa de ensinar a disciplina de Geografia, sendo essa no sentido da palavra ensino o de ser a possibilidade, utilizar e adquirir conhecimento, com base na valorização das informações disponibilizadas, com reflexão, atenção para que seja compreendida. Desta forma, o aprendizado, sendo principal objetivo, seja verificado com resultados que sejam perceptíveis nas aulas, com compromisso e entendimento de realidades apresentadas nessa disciplina. 


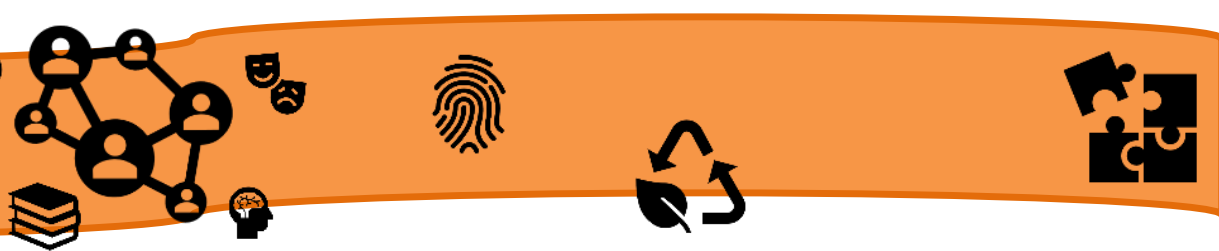

[...] o caminho de ensinar, ocorre como um processo crítico em que o ensinante desafia o educando a apreender o objeto ou conteúdo para apreendê-lo em suas relações com outros objetos, ensinar conteúdos implica o exercício da percepção crítica, de sua ou de suas razões de ser. Implica o aguçamento da curiosidade epistemológica do educando que não pode satisfazer-se com a simples descrição do conceito do objeto. Não devo deixar para um amanhã aleatório algo que faz parte agora, enquanto ensino, de minha tarefa de educador progressista: a leitura crítica do mundo ao lado da leitura crítica da palavra. (FREIRE, 2012, p. 94-95).

Neste caso, como tornar esse desafio em possibilidades é o questionamento que permeia entre professores da disciplina de geografia, sabendo-se que para que novas estratégias sejam agregadas ao desenvolvimento e aprendizagem, requer, um professor mais, flexível, aberto a diálogos, preocupado em acompanhar as mudanças que ocorrem diariamente com os alunos. Como desenvolver temas mais delicados a qual a geografia faz parte também, porque se os alunos ao entenderem a melhor maneira de aprender geografia junto com demais disciplinas, que são atuantes em sala de aula, ainda que esses temas parecem não pertenciam a disciplina, provoca no professor, uma maior investigação de como chamar a atenção e incluir o espaço geográfico com suas condições, podendo ser repensados e incluídas como aprendizagem.

Por exemplo, ao se tratar de meio ambiente, tema muito bem explorado em diversas disciplinas, como a geografia pode ser trabalhada de forma interdisciplinar e dar o seu recado?

De que maneira é possível o aluno entender que o planejamento dentro do ensino de geografia também é possível, para que todos os membros de uma sociedade, possam desfrutar de um ambiente saudável, porque todas as vezes que surgem assuntos como o meio ambiente, economia e assim por diante, espera-se que a disciplina de geografia, exponha sua opinião e que o professor possa refletir junto às demais disciplinas. Como fazer sua intervenção de forma positiva e aproveitar essa possibilidade para que os alunos entendam que na questão de ensino, todas as disciplinas também podem ser discutidas e refletidas, porém em diferentes âmbitos.

há uma complexificação do espaço que se tornou global. O espaço vivenciado hoje é fluido, é formado por redes com limites indefinidos e/ou dinâmicos extrapola o lugar de convívio imediato. É, também, um espaço extremamente segregado, onde cresce a cada dia o número de excluídos, de violentados, de desempregados, de sem terras, de sem tetos (CAVALCANTI, 2002, p. 33). 


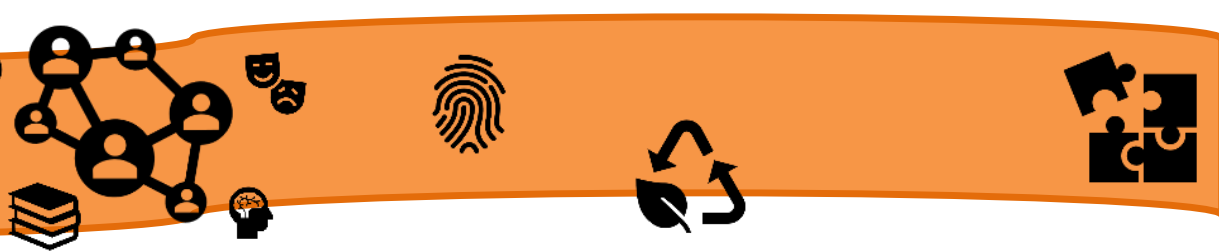

Aproveitar como possibilidades, para desenvolver didáticas possíveis à disciplina de geografia, deve estar além do ciclo de aprendizagem do aluno, seja fundamental II ou ensino médio, pois independente da idade, a oportunidade em fazer pesquisas, mesmo em um mundo em que muitas mudanças e transformações que o ocorreram e o aluno, não presenciou, porém ouviu alguém contar, permite a esse aluno, uma abertura ao entendimento de problemas e situações que ainda permanecem dentro da historia do pais, seja por conta de infraestrutura, economia, meio ambiente entre outros assuntos.

Deve possibilitar que o aluno construa não apenas conceitos e categorias já elaboradas socialmente, mas que (re)signifique tais instrumentais a partir da compreensão do particular, do poder ser diferente nas interpretações e mesmo assim fazer parte do contexto (CASTROGIOVANNI, 2010, p. 85).

Como pontos estratégicos no desenvolvimento de aulas na disciplina de geografia o professor, promove inquietações aos alunos, providas pelas mídias sociais, sobre diversos assuntos como mobilidade urbana, com as qualidades de vida ou não. Dilemas sobre realidades apresentadas na comunidade em que o aluno está inserido, todas situações assim como muitas outras, permitem a possibilidade de desenvolver assuntos com diversas estratégias para que sejam pesquisadas, com a orientação do professor, sendo mediador para que a compreensão e aprendizagem tenham uma conotação avaliativa com grandes resultados.

\begin{abstract}
Assim, professor e aluno estarão envolvidos em situações de aprendizagem que consideram o empírico, o reconhecimento do que existe no lugar, os conhecimentos que o aluno traz consigo a partir de suas vivências, e a busca de teorização destas verdades. Contextualizando-as os alunos fazem as abstrações necessárias, trabalhando com os conceitos científicos e desencadeando a compreensão que permite ir cada vez mais além ao sentido de generalizar experiências particulares e entender a realidade de forma mais ampla. (CALLAI, 2000, p. 103)
\end{abstract}

Ainda que as possibilidades, no desenvolvimento da aprendizagem de geografia se depare com críticas, pela forma de ser ministrada, as estratégias devem ser repensadas sempre pelo professor, para que se ele se atualize e suas aulas sejam mais interessantes e exploradas pelos alunos para que com isso, novas respostas possam ser observadas e registradas pelos alunos. 


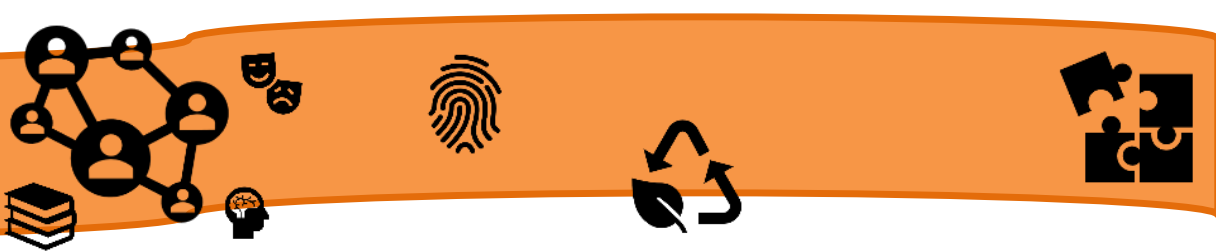

Para ter eficácia, o processo de aprendizagem deve, em primeiro lugar, partir da consciência da época em que vivemos. Isto significa saber o que o mundo é e como ele se define e funciona, de modo a reconhecer o lugar de cada país no conjunto do planeta e o de cada pessoa no conjunto da sociedade humana. É desse modo que se podem formar cidadãos conscientes, capazes de atuar no presente e de ajudar a construir o futuro. (SANTOS, 2008, p. 115).

\section{CONSIDERAÇÕES FINAIS}

Enquanto a aprendizagem da disciplina de geografia é cercada por desafios os quais, não irão desaparecer como um passe de mágica, pois requerem paciência, reflexão, participar de processos de formação para que novas estratégias tenham efeitos significativos no processo de aprendizagem dos alunos.

O público alvo desta aprendizagem são os alunos de hoje, necessitam de estratégias que chamem a atenção para que eles tenham interesse em participar e aprender sobre a disciplina. No caso, na geografia, essa angústia, também é vivenciada por outras disciplinas, mas isso não quer dizer que não tem solução, mas que se deve repensar como atingir esse ensino com resultados positivos em que o aluno realize discussões e questionamentos pertinentes, entendendo que se ele não conseguir entender o que há dentro da disciplina de geografia, não terá como desenvolver esse raciocínio mais crítico e consciente.

Visando isso, ao se deparar com realidades no cotidiano e nas estratégias que vêm sendo disponibilizadas, o professor precisa refletir sobre os fatos do cotidiano e quais são os que mais intrigam esses alunos e utilizar esses assuntos. Ligando ao conteúdo a ser desenvolvido, como possibilidade de que se torne a pesquisa, ainda que utilizando as tecnologias como uma estratégia, conseguindo desta maneira, atingir o conhecimento e aprendizagem dos alunos.

O professor, não precisa deixar de ministrar o conteúdo planejado por ele, mas aproveitar as oportunidades que ocorrem com tantas informações ainda que corriqueiras, mas que mexem com os alunos, juntar ao seu conteúdo e melhorar a visão do aluno quanto a participação da disciplina de geografia no momento em que essas indagações surgiram. Não é a questão, neste artigo, realizar milagres no processo educativo, mas a partir de situações sejam elas trazidas pela mídia ou pela comunidade, 



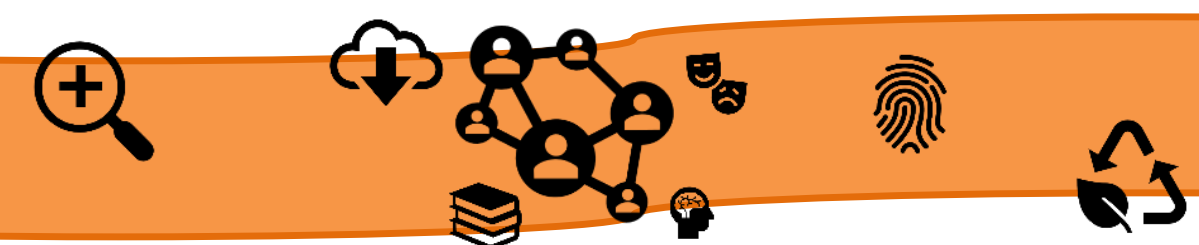

FREIRE, Paulo. Pedagogia do Oprimido. Rio de Janeiro: Paz e Terra, 2005, 42. ${ }^{\mathrm{a}}$ edição.

MORAES A. C. R. (org.). Geografia: pequena história crítica.20. ed. São Paulo: Hucitec, 1994.

SANTOS, Milton. Técnica, Espaço, Tempo: Globalização e meio técnico-científico informacional. São Paulo: Editora da Universidade de São Paulo, 2008.

PONTUSCHKA, Nídia Nacib. Para ensinar e aprender geografia. Nídia Nacib Pontuschka, Tomoko Lyda Paganelli, Núria Hanglei Cacete. - $3^{\mathrm{a} e d .-S P: ~ C o r t e z, ~} 2009$.

TEIXEIRA, A. G. D. Um levantamento de percepções de professores sobre a tecnologia na prática docente. Linguagens e Diálogos, v. 2, n. 1, p. 159-174, 2011. 



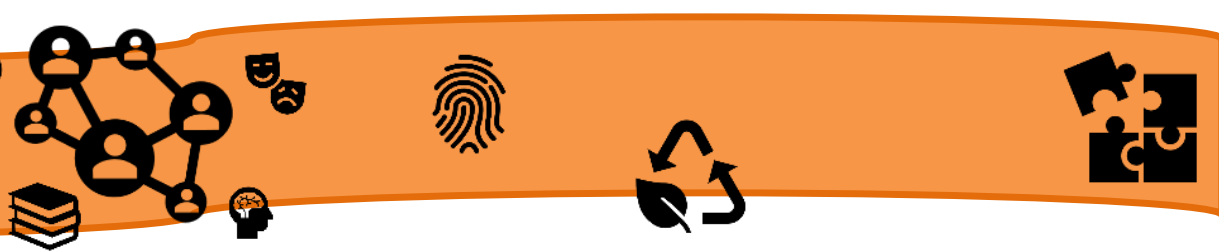

através da LIBRAS. Estão os professores preparados para atender a essa clientela? São essas as questões que serão abordadas neste estudo, utilizando referencias bibliográficas de autores que discutem este tema e constroem resultados positivos. O objeto desse estudo é a formação de professores de Educação Especial para surdos.

\section{A FORMAÇAO DO PROFESSOR: FUNDAMENTAÇAO TEÓRICA}

A Formação de Professores para trabalhar na Educação Inclusiva, embasou-se na teoria de Soares (2003), em que ela cita que, a produção de práticas diversificadas é uma tentativa de responder às questões que são evitadas pela escola. Soares (2003, p. 52), questiona sobre quais "os meios mais eficazes de transmitir aos professores os conhecimentos e as habilidades que a escola exige e que transmitem de forma desigual".

Soares (2003) mostra que atualmente, a inserção de aluno com deficiência no ensino regular tem o significado político diferente, com uma exigência de resposta positiva em relação à permanência desse aluno na escola. Por outro lado, alguns estudiosos citam que a inserção de alunos surdos no ensino regular tem trazido pouco ou nenhum benefício a eles próprios.

Assim, os especialistas têm atuado junto às escolas com objetivo de suprir, tanto aos profissionais da educação comum quanto os profissionais da educação especial, que é o trabalho de apoio pedagógico dado pela escola aos alunos surdos, através da LIBRAS. Soares (2003, p. 10) afirma que:

A proposta curricular para a Educação de surdos e os procedimentos apresentados como estratégias de ensino, não eram diferentes dos utilizados no ensino regular, e que as estratégias que podiam ser consideradas como específicas para o ensino de surdos, são ligadas ao desenvolvimento da fala e da audição.

\section{O PROFESSOR COM ESPECIALIZAÇAO EM LIBRAS}

É indispensável que haja uma melhoria na qualidade da formação dos profissionais da educação, o baixo rendimento escolar na maioria dos alunos com necessidades educacionais especiais, em especial os alunos surdos, inseridos em classes comuns, é um fato notório. A aprendizagem escolar, por parte desses alunos, mostra-se precária e insuficiente, uma consequência das práticas utilizadas pelos professores, os quais não têm formação e conhecimento teórico e pratico para trabalhar com esta clientela especial. 


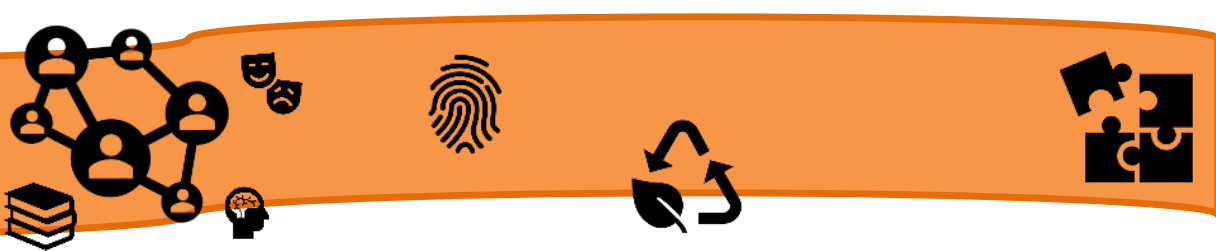

Para mudar este quadro de baixo rendimento, os professores necessitam de passar por uma Especialização, a qual tem como objetivo fundamental capacitá-los para ensinar os conteúdos escolares aos alunos surdos.

É pouco divulgado que desde 2005, se tornou obrigatório a inclusão de disciplina que ensina a Língua Brasileira de Sinais (LIBRAS) em todos os cursos de formação de professores (BRASIL, 2005), com objetivo de desenvolver capacidades e conhecimentos aos professores em trabalhar com qualquer criança que tenha deficiência auditiva, utilizando a LIBRAS para a compreensão de mundo, a comunicação, sua linguagem e o raciocínio.

A importância de o professor estudar LIBRAS em sua formação está relacionada à facilidade que ele terá em receber alunos com necessidades especiais (surdos) em sua turma. Conhecer e dominar LIBRAS proporciona a compreensão e a prática pedagógica desse professor, viabilizando o entendimento e a exploração dos sentidos do aluno surdo, a atenção especial do professor às expressões faciais que o aluno surdo faz em todos os momentos, procurando entender e acompanhar a aula e as tarefas propostas.

A partir da formação em LIBRAS, o professor terá mais facilidade ao planejar atividades que atendam às necessidades dos alunos surdos, dando ênfase no trabalho com repetições para reforçar a mensagem ou a atividade proposta ao aluno. Toda esta prática será possível se o docente buscar estudos que auxilie seu trabalho com esses alunos.

O sucesso no trabalho do professor que atende alunos surdos está relacionado à Especialização em Libras que ele deverá cursar, porque a partir dela, ele estará ciente de um processo global de ensino aprendizagem na escola, onde esses alunos deverão passar boa parte da vida. Portanto, é fundamental que o professor consiga se comunicar e entender a linguagem do aluno surdo, podendo contribuir com a formação escolar e social deles através da inclusão social, ao se comunicar em LIBRAS com a criança. Mesmo que só de forma básica, se o professor demonstrar interesse em incluí-la na turma, faz com que as crianças se sintam parte daquele lugar, e amplia as possibilidades de contato entre eles.

Também através de formação humanizada, em que o professor além de permitir que a criança compreenda a aula, a capacidade de se comunicar em LIBRAS, também permite o oposto: que o professor compreenda o aluno. E ainda o vínculo aluno e 


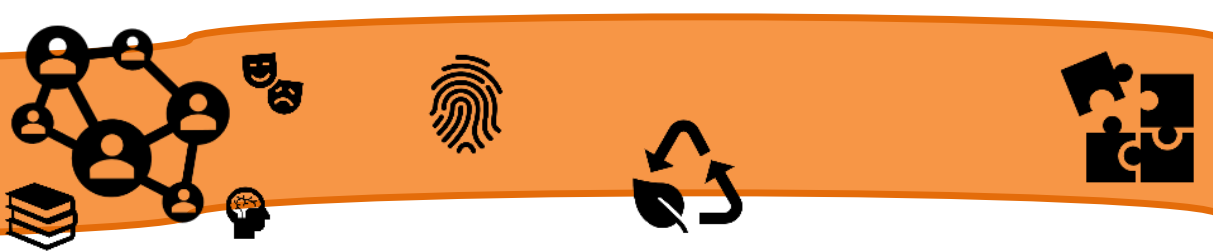

professor quando este docente é uma referência para o aluno, principalmente nos primeiros anos da educação escolar, e construir uma boa relação é de extrema importância para o aprendizado. O vínculo professor e aluno ajuda a criança pequena a estabelecer um ponto de confiança, que fará com que ela busque se espelhar no professor e preste atenção ao que ele ensina.

No campo educacional, o foco à inclusão, parte do princípio de que todas as pessoas podem aprender juntas, independentemente das diferenças que elas possam apresentar. Portanto, as escolas e a sociedade precisam se modificar para responder às necessidades específicas de seus membros. Esta modificação deve partir da formação de professores em LIBRAS.

A inclusão escolar, está garantida nos documentos, tais como: Constituição Federal (1988), Lei de Diretrizes e Bases da Educação Nacional LDB (Lei no 9.394/96), e a Declaração de Salamanca (1994). Esses documentos asseguram: "Atendimento Educacional Especializado, preferencialmente na rede regular de ensino" e deixam claro, que além do acesso, as escolas precisam promover ensino de qualidade, oferecendo: currículo, métodos, técnicas, recursos educativos e organizações específicas, professores do ensino regular, capacitados para atender as peculiaridades dos alunos (LDB inciso I e II, artigo, 59).

É assegurado, também, aos deficientes auditivos, acesso à Língua Brasileira de Sinais (LIBRAS), como meio de comunicação. Portanto, para se cumprir o direito dos alunos surdos, existe a necessidade de um profissional capacitado e habilitado para lidar com a diversidade, com condições de perceber as necessidades e proporcionar respostas, possibilitando o desenvolvimento integral desse educando, afirma Pimenta (2002).

Promover uma educação mais igualitária e inclusiva faz parte dos objetivos ao aprendizado da linguagem de sinais pelos professores, também é um ponto de partida para que não se restrinja aos deficientes auditivos, para que eles possam ter seus círculos sociais ampliados e mais possibilidades de inclusão em atividades comuns para qualquer pessoa, como a Educação formal e o trabalho.

Nesta perspectiva, a linguagem não é apenas uma forma de comunicação, mas é através dela que se constitui o pensamento, logo, o indivíduo. A linguagem para o autor é tudo que envolve significação e está presente no sujeito mesmo quando ele não se comunica (GOLDFELD, 2002). Vygotsky (1988, p. 191) ainda ressalta que: 


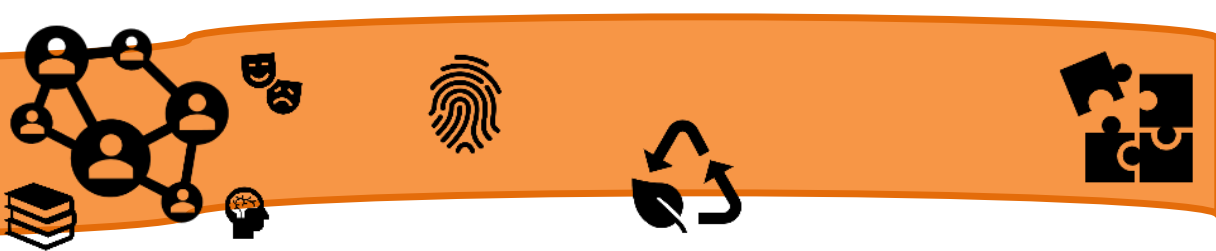

tudo depende de quais exigências fazemos da educação das crianças surdas e quais objetivos que a educação persegue". Também questiona quanto à situação desses alunos, se tem bastado ver os surdos frequentarem os bancos escolares, sem participar das atividades desenvolvidas em sala; olharem a boca do professor sem entender o que ele diz, esperando os movimentos dos colegas para descobrirem o que deverá ser feito, reproduzir o que vai ao quadro, sem compreender o significado.

Tal questionamento deixa claro o quanto a formação dos professores se faz necessária em si, tratando de um trabalho com alunos surdos através do uso de LIBRAS. Desta maneira, chama-se a atenção desses profissionais para que compreendam e transformem sua concepção, a respeito destas pessoas que necessitam de apoio e uma educação especial.

Portanto, a Lei 10.436 de 2002, reconhece a Língua Brasileira de Sinais como a língua oficial da comunidade surda. $\mathrm{O}$ artigo $4^{\mathrm{o}}$ desta lei declara a obrigatoriedade das escolas de formação docente e determina a inserção em suas matrizes a disciplina LIBRAS, com o objetivo de facilitar o processo ensino-aprendizagem e a comunicação entre alunos e professores.

Esta lei é fruto da luta da Comunidade Surda brasileira, garantindo o acesso à escolarização, reconhecendo LIBRAS como meio de comunicação e expressão dos surdos e garantindo a inserção da disciplina Libras como obrigatória nos cursos de licenciatura de nível superior e nos de fonoaudiologia, mas essa realidade está distante das letras dos documentos que foram regidos à luz da lei.

\section{CONCLUSÃO}

$\mathrm{O}$ artigo abordou aspectos referentes à formação profissional de professores em Libras, tomando como ponto de partida a difícil prática em sala de aula e as dificuldades que este professor enfrenta em seu trabalho com alunos surdos que precisam se comunicar através de LIBRAS.

Com uma caminhada longa e árdua, neste processo, o professor tem presenciado como o aluno surdo tem sofrido com o preconceito, ridicularizado e por muitos anos impedidos de exercer seu papel de cidadão. A falta de conhecimento dos professores nesta língua causou uma dicotomia, provocando ainda mais a exclusão por diversos aspectos como: o fato de que as instituições de ensino não estão devidamente adaptadas para receber os alunos surdos em condição especial e em também a falta de 


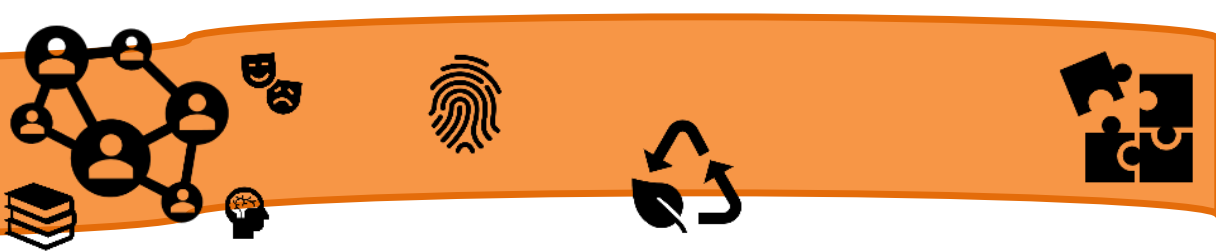

profissionais graduados nesta língua com qualificações para, de fato, haver a transmissão do conteúdo com as devidas assimilações.

As recentes transformações político-educacionais resultam, ainda muito pouco, um novo olhar para esta diversidade, cujo foco está no respeito à identidade e à diferença dos alunos surdos, e na formação profissional de professores em Libras. Neste contexto, busca-se promover a formação de professores afim de proporcionar uma prática pedagógica que viabilize a cidadania para diversas culturas, raças e pessoas com deficiências (no caso a surdez), por meio de leis que garantam sua participação social através da Língua Brasileira de Sinais.

Assim, o indivíduo, ao apropriar-se da linguagem da cultura em que está inserido, altera qualitativamente seu modo de pensar, de perceber o mundo, de memorizá-lo. Por isso, a "linguagem" tem um ponto central na teoria de Vygotsky (1996), uma vez que, sem ela, o desenvolvimento propriamente humano não ocorreria. Contudo, o processo educativo deve provocar revoluções nas pessoas com e sem deficiências e que o professor precisa estar bem preparado.

\section{REFERÊNCIAS}

BRASIL. Decreto Federal n 5.626 de 22 de dezembro de 2005. Regulamenta a Lei no 10.436, de 24 de abril de 2002, que dispõe sobre a Língua Brasileira de Sinais - Libras, e o art. 18 da Lei no 10.098, de 19 de dezembro de 2000. Brasília, 2005.

Lei de Diretrizes e Bases da Educação Nacional. Lei número 9394, 20 de dezembro de 1996.

. MEC. Declaração de Salamanca e linha de ação sobre as necessidades Educativas Especiais. Brasília:

Constituição (1988). Constituição da República Federativa do Brasil. Brasília, DF: Senado Federal: Centro Gráfico, 1988

GOLDFELD, M. A criança surda: linguagem e cognição numa perspectiva sócio interacionista. São Paulo: Plexus, 2002.

PIMENTA, Selma Garrido. Saberes pedagógicos e atividade docente. 3. ed. São Paulo: Cortez, 2002.

SOARES, Maria Aparecida Leite. A Escolarização da Criança Surda e o Professor Especializado. Fórum, Rio de Janeiro, v. 7, p. 11-52. jan./jun. 2003. 
PIMENTA, S. G. Professor reflexivo: construindo uma crítica. In: PIMENTA, S. G.; GHEDIN, E. (Orgs.). Professor reflexivo no Brasil: gênese e crítica de um conceito. São Paulo: Cortez, 2002.

VYGOTSKY, L. S. A formação social da mente. Rio de Janeiro: Martins Fontes, 1996.

Aprendizagem e desenvolvimento intelectual na idade escolar. In:

VIGOTSKY, Lev Semenovich; LURIA, Alexander Romanovich; LEONTIEV, Alexis N. Linguagem, desenvolvimento e aprendizagem. Tradução de Maria da Penha Villalobos. 2. ed. São Paulo: Ícone, 1988. 


\title{
A LUDICIDADE NA EDUCAÇÃO: A RELAÇÃO DO PROCESSO DE ENSINO E APRENDIZAGEM COM O USO DOS JOGOS NA ESCOLA MUNICIPAL PROFESSORA JULIETA MOURA DE SOUZA
}

\author{
AQUINO, Daliene Patrícia Ribeiro $\mathrm{De}^{3}$ \\ RODRIGUES, Wivina Dayane do Nascimento ${ }^{4}$
}

\section{RESUMO:}

O presente trabalho tem por objetivo fazer uma análise e mostrar os resultados alcançados sobre uma pesquisa investigativa em relação ao uso dos jogos na pesquisa, que tenta mostrar os recursos utilizados em sala para trabalhar as atividades lúdicas. A proposta busca saber como as atividades estão sendo desenvolvidas em sala de aula e que metodologias estão sendo utilizadas, especialmente no desenvolvimento de jogos didáticos. Como também, tem o objetivo de apontar o lúdico como proposta pedagógica para ser trabalhado com crianças em sala de aula, aprofundando sobre as dificuldades de aprendizagem e apontando para a necessidade de tornar as aulas mais prazerosas. Tendo em mente que é fundamental compreender a atividade lúdica para usá-la como recurso pedagógico, pois, conquistado esse conhecimento o professor poderá intervir de maneira efetiva no processo de aquisição de conhecimento e na busca de subsídios que atendam as reais necessidades de seus alunos com dificuldades de aprendizagem. Lembrando que a razão do aprofundamento desse tema favorecerá pais, professores, coordenadores e direção, orientando sobre as possíveis relações entre o brincar e o desenvolvimento infantil em seus aspectos cognitivo, social e afetivo.

PALAVRAS-CHAVE: Lúdico. Brincadeiras. Interação.

\section{INTRODUÇÃO}

Sabemos o quão importante é o processo de reflexão sobre a ação do professor, pois é somente por meio dela que o mesmo poderá avaliar seu trabalho em sala de aula e, desta forma modificar sua metodologia, fazendo valer a responsabilidade e o compromisso que lhe foi designada como profissional da Educação. Com base nesse pressuposto, veio a ideia de fazer uma análise investigativa para se ter o conhecimento de como está sendo desenvolvido o trabalho destes em relação aos jogos nas turmas do Ensino Infantil da Escola Municipal Professora Julieta Moura de Souza, na zona rural da cidade de Ipanguaçú - RN.

\footnotetext{
${ }^{3}$ Mestranda do Curso de Ciências da Educação pela Faculdade do Estado do Maranhão (FACEM). Professora da Educação Básica do Município de Guamaré/RN. E-mail: ribeiroaquinodaliene @gmail.com

4 Mestranda do Curso de Ciências da Educação pela Faculdade do Estado do Maranhão (FACEM). Professora da Educação Básica do RN. E-mail: wivinadayane@gmail.com
} 


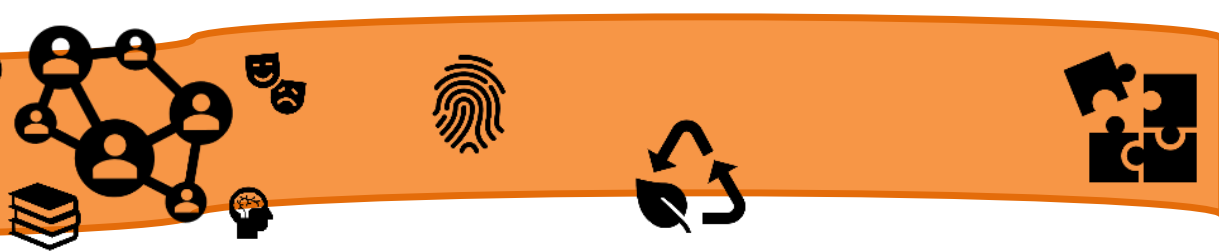

Em virtude do objetivo da pesquisa optou-se por uma pesquisa qualitativa, tendo com foco principal a análise da importância do lúdico no processo de ensinoaprendizagem.

Para Silva e Gonçalves (2010) o brincar e o jogar são momentos cruciais na vida de qualquer indivíduo. Com isso, é por meio dos jogos e das brincadeiras que as crianças ampliam seus conhecimentos sobre o mundo que está ao seu redor, desenvolvem as múltiplas linguagens, manipulam e exploram objetos, organizam seu pensamento, descobrem, seguem e agem com as regras, assumem função de líderes e se socializam com outras crianças, preparando-se para um mundo socializado.

Com base nesse pressuposto, a análise parte do princípio de que uma aula integrada aos jogos lúdicos didáticos possui um dos melhores métodos para que a aprendizagem seja significativa, pois a mesma é uma aula em que está voltada para o interesse dos alunos e que ao mesmo tempo não perde seus objetivos.

Quanto a importância dos jogos para o processo de ensino e aprendizagem, defende Brougere (1995, p. 89):

\footnotetext{
Por envolverem extrema dedicação e entusiasmo, os jogos das crianças são fundamentais para o desenvolvimento de diferentes condutas e também para a aprendizagem de diversos tipos de conhecimento, podendo então, definir, o espaço do jogo como um espaço de experiência e liberdade de criação no qual as crianças expressam suas emoções, sensações e pensamento sobre o mundo e também um espaço de interação consigo mesmo e com os outros.
}

Segundo o pensamento de Brougere, compreende que é pela brincadeira que a criança interage consigo mesmo e com o meio que nos cerca, demonstrando suas emoções, sentimentos e sensações acerca do mundo à sua volta. Essa forma de interação permite o desenvolvimento de várias condutas, e também de diversos tipos de conhecimento, pois no momento da brincadeira a criança dedica total atenção e entusiasmo, fator esse que possibilita uma aprendizagem cada vez mais significativa.

Com isso, cabe ao professor proporcionar momentos para que as crianças possam vivenciar em sala de aula, pois, por serem atraentes, podem ser realizadas facilmente, quantas vezes o desejar, criando e recriando as situações que ajudam a satisfazer alguma necessidade presente em seu interior. O jogo corresponde a um impulso natural da criança, e neste sentido satisfaz a uma necessidade interior, pois todo ser humano apresenta uma tendência lúdica. 


\section{A IMPORTÂNCIA DO LÚDICO NO ENSINO}

O lúdico é de fundamental importância para a Educação, principalmente para a Educação Infantil, pois é prazeroso para o aluno participar de atividades que aparentemente poderia ser uma brincadeira, ele participa e se envolve. O aluno vê sentido no que está sendo apresentado a ele, e, quando menos espera, termos e conceitos já fazem parte do seu cotidiano.

Amaral (2008), em seu trabalho final utilizando a Teoria socioconstrutivista de Vygotsky, afirma que o desenvolvimento humano é realizado em trocas recíprocas, entre o indivíduo e o meio, entendendo que meio não e só o ambiente que vive, mas também as pessoas que nele estão inseridas. O lúdico neste contexto irá permitir trocas entre os alunos e com os seus conhecimentos, tanto os empíricos, quanto com a matéria a ser apreendida.

Etimologicamente, o termo Lúdico, tem sua origem no Latim, cujo significado é illusio, um termo de retórica que equivalia à "ironia". Tratava-se de um artifício do discurso em que o orador debochava de um adversário, fingindo dizer coisa diferente do que ele na realidade estava falando. O termo se forma por in-, dando a sensação de inclusão, mais ludere, de ludus, “jogo, brincadeira”, que deriva do Indo-Europeu leidh-, "brincar".

Diante da importância ao uso da ludicidade em sala de aula, é habitual observar que os docentes e coordenadores estão mais preocupados com a organização comportamental e disciplinar da sala, e, portanto, veem o lúdico como uma brincadeira sem significativo. Eles não sabem que ao fazerem isto estão desconsiderando o potencial desta ferramenta, onde a mesma é capaz de estimular o aluno a pensar, a partir de novos paradigmas, e a criar novas hipóteses e regras, como também explorar suas criatividades e potencialidades se sentido o objeto e alvo essencial dentro do papel da educação.

Os jogos tem sido alvo de inúmeras pesquisas como método de ensino, no entanto, a maioria dessas rodeia em torno dos primeiros anos do ensino fundamental. É com alunos dessas séries que os docentes têm mais dificuldades em ensinar, pois na maioria das vezes são alunos que ainda não tem o domínio da leitura e da escrita, logo, a 


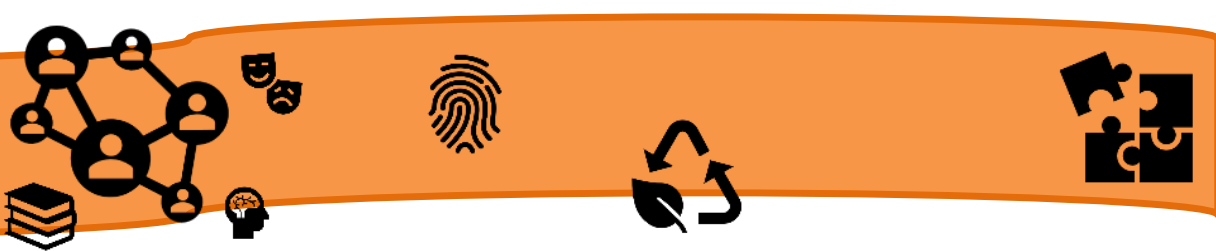

maioria percorre aos brinquedos como ferramenta essencial para facilitar o ensino e a aprendizagem de seus discentes, principalmente nos conteúdos de matemática.

De acordo com o pensamento de Santos (2009, p.14):

[...] os jogos coletivos também exercem um papel primordial no ensino da matemática, pois a participação de alunos em jogos de grupo representa uma conquista cognitiva, emocional, moral e social. Individual ou coletivamente o trabalho com os jogos são significativos e prazerosos, desde que bem direcionados, caso contrário não passará de mais uma atividade sem proveito pedagógico.

Os conteúdos de matemática são considerados pelos alunos como um "bicho de sete cabeças", portanto, é importante que os docentes procurem algo atrativo, prazeroso na aprendizagem desses conteúdos, ou seja, algo que faça com que os alunos quebrem esse preconceito. Nesse sentido, o ensino-aprendizagem da matemática requer o uso de instrumentos mediadores de conhecimento, visto que através de jogos matemáticos as crianças podem desenvolver a autonomia, as relações de respeito e de confiança em si e nos colegas.

\section{OS RECURSOS DOS JOGOS SEGUNDO OS PARÂMETROS CURRICULARES NACIONAIS}

Lecionar no Ensino Fundamental não é nada fácil, todos os dias estamos lidando com crianças que estão começando a sua aprendizagem. Assim, a maior preocupação é considerar de fato o que se sabe a respeito das demandas cognitivas de tarefas como linguagem, leitura, números e os problemas que as crianças enfrentam durante aprendizagem.

Segundo os Parâmetros Curriculares Nacionais (1998) "Os jogos são importantes principalmente para o ensino das crianças pequenas, os mesmos são as ações que elas repetem sistematicamente, mas que possuem um sentido funcional (jogos de exercício), isto é, são fonte de significados e, portanto, possibilitam o entendimento, geram prazer, formam hábitos que se estruturam num sistema”. Essa repetição funcional também deve estar presente na atividade escolar, pois é essencial no sentido de ajudar a criança a perceber regularidades.

Através da ludicidade que podemos desenvolver várias atividades em sala de aula, mas não se pode confundir as aulas com brincadeiras sem objetivos, ou seja, 


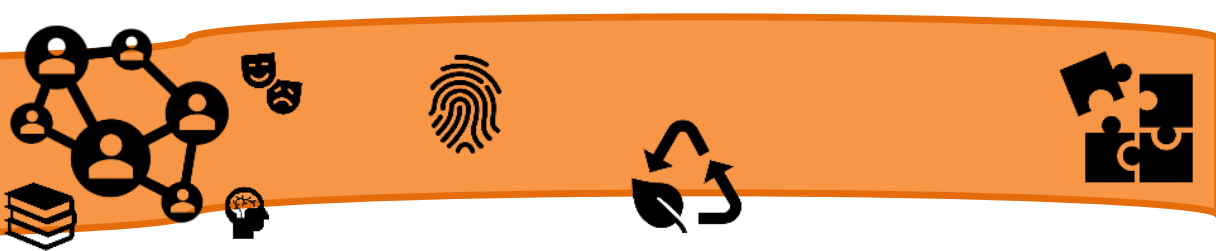

brincar apenas como um "passatempo". Para Teixeira (1995) “[...] o jogo é um fator didático altamente importante, mais do que um passatempo, ele é elemento indispensável para o processo de ensino-aprendizagem”. Educar através de jogos deve, portanto, ser a preocupação básica de todos os professores que têm intenção de motivar seus alunos ao aprendizado, principalmente os do Ensino Infantil e do Ensino Fundamental, já que os mesmo estão em sua fase inicial de aprendizagem.

Os Parâmetros Curriculares Nacionais (1998, p. 35) nos assegura que:

Por meio dos jogos as crianças não apenas vivenciam situações que se repetem, mas aprendem a lidar com símbolos e a pensar por analogia (jogos simbólicos): os significados das coisas passam a ser imaginados por elas. Ao criarem essas analogias, tornam-se produtoras de linguagens, criadoras de convenções, capacitando-se para se submeterem a regras e dar explicações.

Isso é benéfico, principalmente para ensinar os conteúdos de matemática, conteúdos estes que a maioria dos pedagogos tem dificuldades de passar para seus alunos a compreensão e a utilização de convenções e regras que serão empregadas no processo de ensino e aprendizagem. Essa compreensão favorece sua integração num mundo social bastante complexo e proporciona as primeiras aproximações com futuras teorizações.

As crianças ao ingressarem no Ensino Fundamental é que vão aprender lidar com situações mais complexas (jogos com regras) e compreender que as regras podem ser combinações arbitrárias que os jogadores definem; como também perceber que só podem jogar em função da jogada do outro (ou da jogada anterior, se o jogo for solitário). Os jogos com regras têm um aspecto importante, pois neles o fazer e o compreender constituem faces de uma mesma moeda.

De acordo com os Parâmetros Curriculares Nacionais (1998, p. 36):

[...] um aspecto relevante nos jogos é o desafio genuíno que eles provocam no aluno, que gera interesse e prazer. Por isso, é importante que os jogos façam parte da cultura escolar, cabendo ao professor analisar e avaliar a potencialidade educativa dos diferentes jogos e o aspecto curricular que se deseja desenvolver.

Os jogos têm função importante na aprendizagem quando é bem aplicado, e bem orientado, através deles é possível desenvolver competências de raciocínio como organização, atenção e concentração, tão necessárias para o aprendizado, e para a resolução de problemas em geral. Como também os professores podem identificar o 


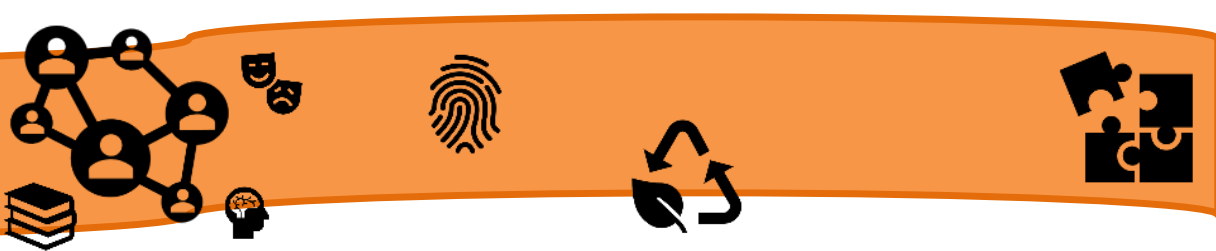

desenvolvimento da linguagem, criatividade e raciocínio dedutivo, exigidos na escolha de uma jogada e na argumentação necessária durante a troca de informações.

Entretanto, para que os jogos sejam inclusos na vida dos alunos é fundamental à motivação no trabalho docente, a mesma contribui para o processo de ensinoaprendizagem, pois, nem sempre recebe a devida atenção do professor no desenvolvimento do seu trabalho. Muitas vezes, ele se ocupa em providenciar material e transmitir o conteúdo e se esquece da motivação, fator chave para o bom desenvolvimento do aluno.

Para Souza (2012), "no contexto escolar a motivação tem sido um fator relevante a ser estudado e compreendido tanto no processo de aprendizagem dos alunos como nas estratégias e conceitos de ensino adotados pelos professores". Na escola o trabalho do aluno é essencialmente cognitivo e envolve concentração, atenção entre outras condições importantes, neste caso a motivação está relacionada às atividades de aprendizagem.

\section{OS JOGOS NA EDUCAÇÃO}

Os Jogos educativos facilitam o processo de ensino-aprendizagem, onde os mesmos podem tornar as atividades prazerosas, interessantes e desafiadoras. Entretanto, o jogo é um ótimo recurso didático ou estratégia de ensino para os docentes, como também pode ser um rico instrumento para a construção do conhecimento.

Para Xavier, Oliveira e Costa (2013) "é importante o desenvolvimento de atividades lúdicas tanto no ambiente da sala de aula como fora dela, pois elas auxiliam no processo ensino-aprendizagem, uma vez que conhecimentos são apreendidos sem serem impostos, mas de forma mais prazerosa". Sendo assim, devemos ter ciência que não é somente na escola que é adquirido o conhecimento, mas em qualquer ambiente, seja brincando com os pais, avós, amigos entre outros, o importante é que esse conhecimento seja significativo e que possa servir para a vida, e que no futuro possamos repassar para outras gerações.

Através de jogos, como dominó, palavras cruzadas, memória entre outros é possível a aprendizagem dos alunos mais interessante e até mesmo divertido. Para que isso aconteça é preciso que eles sejam utilizados ocasionalmente para preencher as lacunas que se produzem na atividade escolar diária, para que a partir daí se possa 
verificar os aspectos que por si só justificam a incorporação do jogo nas aulas. São estes: o caráter lúdico, o desenvolvimento de técnicas intelectuais e a formação de relações sociais.

\section{O caráter lúdico}

Esta abordagem é baseada na exploração da linguagem, dando prazer em lidar com as palavras, imitar sons e descobrir as relações. As rimas, as lengalengas, as travalínguas e as adivinhas são aspectos da tradição cultural portuguesa que podem ser trabalhados na educação, também a poesia como forma literária constitui um meio de descoberta da língua e de sensibilização estética. Todas estas formas de expressão permitem trabalhar ritmos, pelo que se ligam à expressão musical, facilitando a clareza da articulação e podem ainda ser meio de competência metalinguística, ou seja, de compreensão do funcionamento da língua.

\section{Lengalenga}

Mesmo para aqueles que conhecem o termo, não existe um consenso quanto à sua definição. Enquanto que, segundo o dicionário, uma "lengalenga" é uma narração fastidiosa e extensa, para outros, são jogos de palavras com rimas e ritmos surpreendentes, que registram uma espécie de cumplicidade entre adultos e crianças e onde a diversidade do sentido das palavras e das frases fazem, por vezes, de textos divertidos, quebra-cabeças sem saída. Já para o site Webnod uma "lengalenga" é uma cantilena transmitida de geração em geração na qual se repetem determinadas palavras ou expressões.

Através das "lengalengas" o professor poderá explorar com os alunos os conteúdos expostos nas atividades e trabalhar as frases, as palavras e os fonemas, utilizando as várias ferramentas para interagir no ambiente sobre os objetos existentes. A partir daí os alunos poderão, por exemplo, tentar construir novas palavras através das sílabas que resultam da divisão das outras palavras. O objetivo de trabalhar esse tipo de atividade é alcançar melhores resultados, a nível da compreensão dos temas, da interação, da atenção e motivação dos alunos. 


\section{Adivinha}

As adivinhas, também conhecidas como adivinhações ou "o que é, o que é" são perguntas em formato de charadas desafiadoras que fazem as pessoas pensar e se divertir. São criadas pelas pessoas e fazem parte da cultura popular e do folclore brasileiro. São muito comuns entre as crianças, mas também fazem sucesso entre os adultos.

Através das adivinhas os alunos irão ler com desenvoltura diferentes adivinhas, participar de uma discussão sobre o tema demonstrando conhecimentos variados, envolver-se, ativamente, em uma brincadeira de adivinhação e expressar-se, através de desenhos, sobre o tema proposto.

Segundo o site professore solidários "A adivinha é um gênero cujo objetivo é desafiar, brincar, tentar descobrir. Assim, as adivinhas devem ser ditas ou lidas e as respostas buscadas". O professor pode propor que os alunos tentem descobrir as respostas oralmente, coletivamente ou em pequenos grupos, como também pode dar dicas e ajudar. Depois das sugestões, dos palpites das crianças (ou adultos), se ninguém acertar, a professora diz a resposta da adivinha, relendo-a para que a pergunta seja ressignificada.

Quando os alunos souberem todas as respostas, pode-se, então, dar início à atividade de leitura. Evidentemente, outras atividades com as adivinhas, essas e outras, podem ser propostas, de leitura, escrita, de produção de pequenos livros, gravações, de ilustração, enfim, uma série de possibilidades, para isso vai a criatividade do professor e envolvimento da turma.

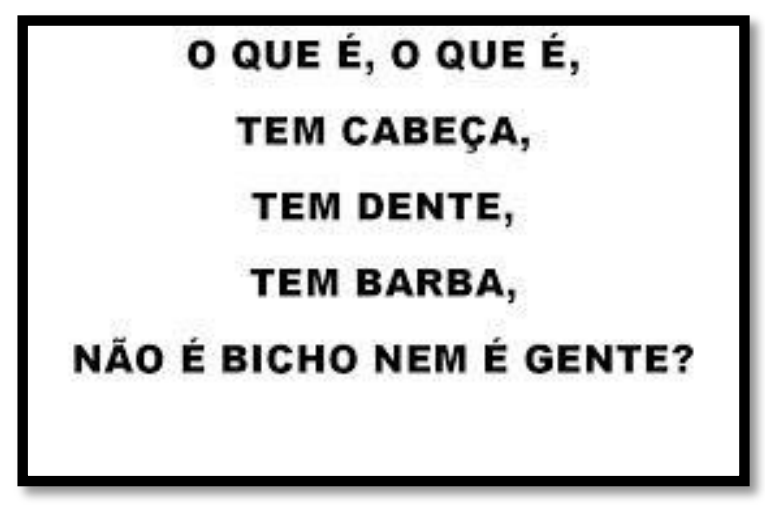

\section{A LUDICIDADE NA ESCOLA MUNICIPAL PROFESSORA JULIETA MOURA DE SOUZA}


Diante da necessidade de averiguar a presença da ludicidade e da brincadeira nas séries iniciais do Ensino fundamental da Escola Municipal Professora Julieta Moura de Souza foram aplicados questionários para os professores da referida instituição. A escola dispõe de 8 professores que atuam nas séries iniciais, no entanto, apenas 5 estavam disponíveis para responder.

Em virtude do objetivo da pesquisa optou-se por uma pesquisa qualitativa, tendo com foco principal a análise da importância do lúdico no processo de ensinoaprendizagem. Os professores foram receptivos à realização dos questionários. Dos que responderam, em sua maioria constituíam-se de mulheres, sendo que somente um dos professores entrevistados é do sexo masculino.

O questionário aplicado aos docentes continha as seguintes questões:

$1^{\circ}$ ) Qual a sua formação acadêmica?

( ) graduação ( ) especialização ( ) mestrado ( ) doutorado

$2^{\circ}$ ) Há quanto tempo leciona?

$3^{\circ}$ ) Você trabalha com o lúdico em sua(s) sala(s) de aula? Se positivo, há quanto tempo?

$4^{\circ}$ ) Que atividades lúdicas você adota em sua sala de aula?

$5^{\circ}$ ) Você verifica alguma(s) contribuição(ões) do lúdico para aprendizagem dos seus alunos? ( )sim ( ) não. Explicite.

$6^{\circ}$ ) Como os alunos reagem às atividades lúdicas?

$\left.7^{\circ}\right)$ Que recursos você utiliza como ferramenta lúdica?

Diante das perguntas elaboradas no questionário, foram obtidas respostas que foram de suma importância para se ter o conhecimento de como os docentes da Escola Municipal Professora Julieta Moura de Souza lidam com as atividades lúdicas.

A pergunta $1^{\circ}$ que fala sobre o grau de escolaridade dos professores, $80 \%$ são graduados e apenas $20 \%$ são especialistas.

A pergunta $2^{\circ}$ que fala do tempo que cada profissional leciona tivemos os seguintes resultados:

$$
\begin{aligned}
& 20 \% \text { - } 0 \text { a } 5 \text { anos } \\
& 40 \% \text { - } 6 \text { a } 10 \text { anos } \\
& 20 \% \text { - } 11 \text { a } 15 \text { anos }
\end{aligned}
$$


$20 \%-16$ a 20 anos

O que mais chamou a atenção foi o único especialista da Escola, ele só tem 3 anos que leciona e já tem Especialização.

Quando perguntado a respeito da presença do lúdico e da brincadeira nas séries iniciais os professores foram unânimes em afirmar que trabalham em suas aulas desde o período que lecionam. Veja os relatos a seguir:

Professor A: sim, desde o período em que leciono, pois ensinar a crianças exige esse método de ensino;

Professor B: Sim, sempre trabalhe com o lúdico na sala de aula;

Professor C: Sim, desde o período em que comecei a lecionar;

Professor D: Sim, desde o período que leciono;

Professor E: Sim, sempre trabalhei com atividades lúdicas, mas confesso que utilizo com mais frequência nos últimos 10 anos, período em que comecei a ter mais acesso aos recursos tecnológicos.

Os relatos a seguir referem-se a que atividades lúdicas os professores adotam em sua sala de aula. Veja a seguir:

Professor A: Dominó, Jogo da velha, caça-palavras e atividades xerocadas;

Professor B: Apenas com as que estão disponíveis na escola;

Professor C: Brincadeiras impressas, cabra-cega entre outros;

Professor D: Jogos, caça-palavras, lengalengas entre outros;

Professor E: Cantigas, jogos de baralhos com números, jogos

Professor E: Cantigas, jogos de baralhos com números, jogos de dados entre outros.

É possível perceber que os professores trabalham as atividades lúdicas em sala de aula de forma diferenciada, buscando inovar os recursos para uma aula diferenciada, exceto a professora B. A mesma chamou atenção no seu relato quando disse que trabalha apenas com as atividades que estão disponíveis na escola e em momento algum 
citou outras, no entanto, pode-se afirmar que ela trabalha com atividades lúdicas, porque a escola dispõe, não se preocupando em inová-las, ou seja, não faz o uso da internet para buscar novas atividades que lá estão disponíveis.

A questão de número 6 tinha a seguinte pergunta: Você verifica alguma(s) contribuição(ões) do lúdico para aprendizagem dos seus alunos? ( ) sim ( ) não. Explicite.

Professor A: Sim, os alunos se sentem motivados ao perceber que realmente sabe dos conteúdos abordados durante as atividades;

Professor B: Sim, motiva e ajuda na aprendizagem, facilitando a compreensão e fixando o conhecimento;

Professor C: Sim, em todas as atividades lúdicas é possível perceber a contribuição em relação a aprendizagem;

Professor D: Sim, as crianças adoram as atividades novas, principalmente aquelas que trago pela primeira vez para a sala de aula;

Professor E: Sim, percebo que os discentes desenvolvem o ensino aprendizagem com mais facilidade.

Deste modo, é possível perceber que todos os professores entrevistados consideram a presença da brincadeira e do lúdico importantes no ensino fundamental. No entanto, é importante que os professores considerem esses dois elementos significativos no processo de aprendizagem dos alunos e utilizem como uma prática constante no ensino.

Quando perguntado que recursos os professores utilizam como ferramenta lúdica, os mesmos responderam da seguinte forma:

Professor A: Internet, fantoches e aparelhos de multimídia;

Professor B: Jogos que estão disponíveis na escola;

Professor C: Aparelhos de multimídia, atividades xerocadas $e$ impressas da internet;

Professor D: Aparelhos de som, DVD, TV e atividades xerocadas; 


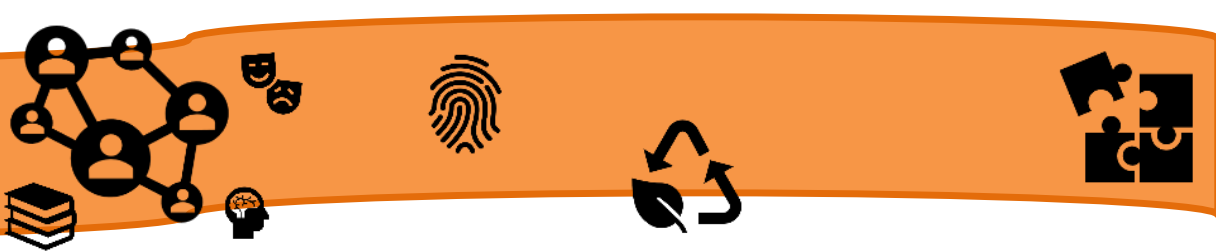

Os professores necessitam passar por um aprendizado para que possam se utilizar dessas novas tecnologias sabendo a melhor forma de utilizá-las com o aluno. Além do professor, a escola deve mudar seus conceitos quando se fala de concepção do conhecimento, ou seja, de como é passado o conhecimento para o aluno.

É importante que as escolas promovam projetos pedagógicos, que contemplem as atividades lúdicas, envolvendo as crianças com atividades planejadas, orientadas e com objetivos significativos à aprendizagem e o desenvolvimento integral das crianças. Sendo também de suma importância a realização de oficinas, onde tenham o objetivo de criar os próprios brinquedos, pois através deste momento de criação, os alunos desenvolvem a imaginação, o valor da construção e do brinquedo criado e inventado por ele, desenvolvendo a concentração, imaginação, raciocínio e promovendo a autoestima e outras habilidades.

Enfim, diante da nossa investigativa, pôde-se ter o conhecimento de como está sendo desenvolvido o trabalho dos docentes na Escola Julieta Moura de Souza em relação aos jogos nas salas de aulas, deixando claro a importância que esta unidade de ensino cobre mais de seus professores, principalmente quando se diz respeito aos recursos tecnológicos que a mesma oferece, tornando obrigatório o uso não só nas atividades lúdicas, mas em todas as aulas por eles ministradas.

\section{REFERÊNCIAS}

BRASIL. Parâmetros Curriculares Nacionais (PCNs). Educação Infantil. Brasília: MEC/SEF, 1998.

BROUGERE, Gilles. Brinquedo e cultura. São Paulo: Cortez, 1995.

MARIA, Cícera. O que é trava língua? Definição e exemplo. 2009. Disponível em: http://www.recantodasletras.com.br/infantil/1694429. Acesso em: 17 de dezembro de 2016.

MORAIS, Rommel Xenofonte Teles de. Software educacional: a importância de sua avaliação e do seu uso nas salas de aula. 2003. Disponível em:

http://www.flf.edu.br/revista-flf/monografias-computacao/monografia-rommelxenofonte.pdf. Acesso em: 20 de dezembro de 2016.

PEREIRA, Márcia de Andrade. Ensino-Aprendizagem em um contexto dinâmico - o caso de planejamento de transporte. São Carlos 2005. Tese (Doutorado): Escola de Engenharia de São Carlos da USP. 
SANTOS, Genilson Ferreira dos. Os jogos como método facilitador no ensino de matemática. 2009 Disponível em:

http://www.cdn.ueg.br/arquivos/jussara/conteudoN/1209/Genilson_PDF_2.pdf. Acesso em 08 de dezembro de 2016.

SILVA, T.A.C.; GONÇALVES, K.G.F. Manual de Lazer e Recreação: O mundo lúdico ao alcance de todos. São Paulo: Phorte Editora, 2010.

SOUZA, Angelita de. Motivação docente: uma pesquisa bibliográfica. Disponível em:http://www.uel.br/ceca/pedagogia/pages/arquivos/ANGELITA\%20DE\%20SOUZA. pdf. Acesso em 10 de dezembro de 2016.

TEIXEIRA, Carlos E. J. A ludicidade. São Paulo: Loyola, 1995. 



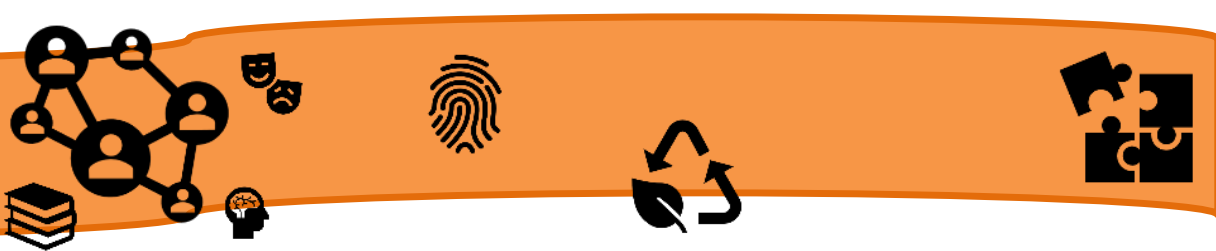

aumento da agressividade dentro das instituições escolares é característico da falta de intervenção pedagógica. "A nova escola" ainda não se deu conta de que está envelhecida. Para uma intervenção pedagógica eficaz, consideramos que as políticas públicas para a educação precisam ser revistas, reformuladas, para que valorizem o enfrentamento de problemas de grande impacto social, como é o caso da violência, geradora de base da agressividade.

O presente objeto de estudo tem a finalidade de abordar as características dessa violência que está cada vez mais presente em escolas públicas. Surgiu da necessidade de constituir neste contexto, conhecimentos pedagógicos para que os profissionais envolvidos no processo educativo, possam desenvolver projetos educacionais no âmbito escolar e fora dele para conduzir a agressividade em favor da aprendizagem, e diminuindo assim, o índice de violência nas escolas e na sociedade.

Nota-se que cada vez mais os alunos demonstram comportamentos e atitudes agressivos, ferindo tanto a integridade física, quanto a psicológica de colegas e professores. Por esse motivo, faz-se necessário uma investigação mais consistente das causas dessa violência, bem como, as possíveis alternativas para compreender e modificar essa situação.

A pesquisa vislumbra discutir os fatores contribuintes para crianças e adolescentes agressivos e/ou violentos no âmbito escolar, visando as questões norteadoras:

- Que atitude a escola deve tomar com relação a aluno de perfil agressivo e/ou violento?

- É dever da escola combater a agressividade?

- Por que crianças e adolescentes apresentam condutas cada vez mais agressivas no âmbito escolar?

- Que fatores influenciam a agressividade dentro do âmbito escolar?

Este trabalho pretende responder as questões a partir da análise de informações da família, escola e por meio de pesquisa bibliográfica sobre a temática.

Objetiva-se neste trabalho, analisar concepções de agressão presentes na Educação Básica nas escolas públicas nos anos iniciais; o papel da escola frente aos problemas de convivência dos alunos no âmbito escolar; e como elas orientam condutas que possam contribuir na condução da agressividade. 


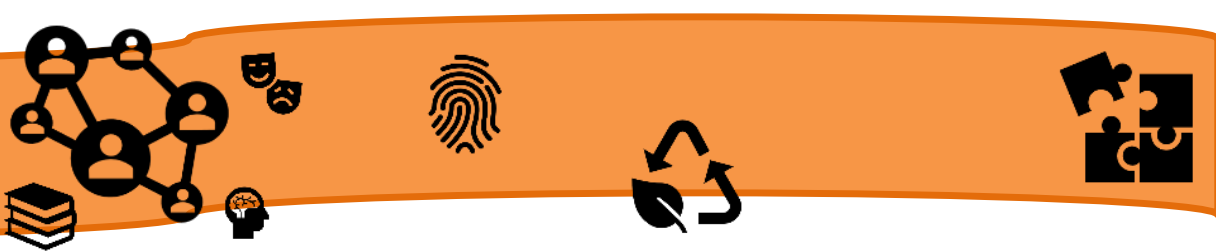

O trabalho está dividido em três seções: a primeira, sobre a agressividade no contexto familiar e escolar. Na segunda, será apresentada a ação docente frente ao aluno agressivo. E na terceira, aponta ações preventivas contra a agressividade. Em seguida, será apresentado o método de estudo com a apresentação do estudo de caso, seguido dos resultados e discussões, finalizando com as considerações finais. Neste trabalho, trataremos do caminho percorrido desde o início do trabalho, suas contribuições para a prática clínica pedagógica, o que se pretende e como vamos utilizar esse conhecimento posteriormente.

\section{AGRESSIVIDADE NO CONTEXTO ESCOLAR E FAMILIAR}

As pesquisas sobre a violência na escola procuram denominações e conceitos que explicam a agressão desmedida, que nos leva a perceber que os alunos estão cada vez mais "violentos" nas escolas, por diversos fatores, dentre eles, na grande maioria, devido à falta de conscientização dos próprios pais.

Assim, entendemos que estes são as maiores influências para os filhos, que os educam, com quem convivem e aprendem, e muitas das vezes acabam repetindo as mesmas frustrações e opressões que sofreram em casa com os colegas em sala de aula, alguns, até com professores.

Os estudos também apontam que é necessário diferenciar violência de agressividade, segundo Marcelos (2011, p. 1):

\footnotetext{
Violência representa agressão física, simbolizada pelo estupro, brigas em família e também a falta de respeito entre as pessoas. [...] A agressividade é o comportamento adaptativo intenso, ou seja, o indivíduo que é vítima de violência constante tem dificuldade de se relacionar com o próximo e de estabelecer limites porque estes às vezes não foram construídos no âmbito familiar. $\mathrm{O}$ sujeito agressivo tem atitudes agressivas para se defender e não é tido como violento entre as pessoas.
}

Portanto, agressividade não é sinônimo de violência, porém, pode gerar violência. No caso de se tornar violento, o faz porque precisa, às vezes para se defender, porém, necessariamente não será um aluno violento que causará danos ao patrimônio e nem dano físico ao próximo que divide o ambiente escolar com ele.

A escola, neste contexto, tenta trabalhar juntamente com os pais na educação dessas crianças e adolescentes, de forma que possam auxiliá-los a mostrar qual caminho 


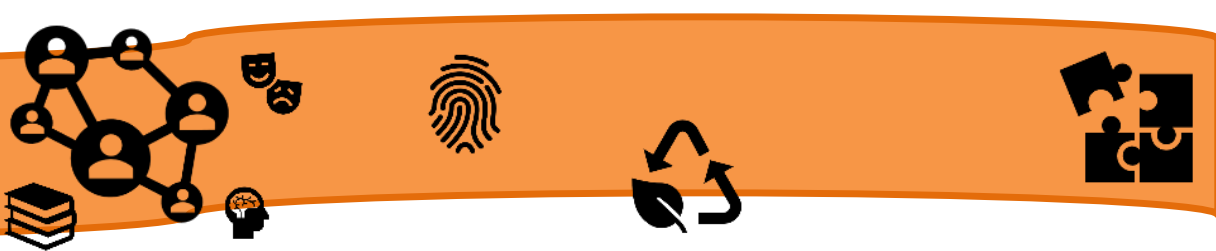

deve ser seguido. Desta forma, pretendemos analisar e refletir sobre as questões da violência e da agressividade, buscando compreender a dimensão de uma e de outra, e anunciar elementos de controle e possíveis soluções para que se evite a manifestação de atos de violência no ambiente escolar.

No campo da Psicologia do Desenvolvimento, o principal foco de investigação dos estudos sobre violência doméstica são as consequências negativas. Desde a década de 1960, os estudos médicos têm contribuído para identificar os casos de violência contra crianças e definir os prejuízos psicológicos associados à conduta agressiva dos pais (HUTZ, 2005).

A agressividade não deve ser respondida com agressividade, mas com outro tipo de resposta mais adaptativa, que reflita o entendimento. É necessário que profissionais estejam cientes desses dados no momento de planificar programas de prevenção e intervenção e, também, sejam tolerantes com essas crianças, considerando características dos contextos nos quais estas se desenvolvem (KOLLER, 2004). No caso do contexto escolar, faz-se necessário estimular a presença do elemento afetivo e da comunicação mais igualitária, nas relações interpessoais (LISBOA e KOLLER, 2001).

Algumas crianças demonstram agressividade desde a iniciação escolar, e isto se dá principalmente pela falta de imposição de limites, que deve ser feita pelos próprios pais. Para Lopes (2011), esse tipo de comportamento se inicia a partir dos quatro anos de idade, tais como mordidas, arranhões, tapas, até mesmo gritos e chutes. Ou seja, é a partir deste momento, que os limites devem ser impostos para que a criança comece a ter consciência a respeito das regras de convivência.

Acontece que, na maioria das vezes, a violência dos alunos dentro e fora das escolas, é um reflexo do que vivem no dia a dia na rua e até mesmo dentro de casa, onde se pode constatar que muitos casos de agressão na escola se originam na violência doméstica, ou seja, violência de pais para com os filhos, e até mesmo entre os próprios pais.

[...] muitos fatores interferem no modo pelo qual a criança lida com a experiência de testemunhar a agressão da mãe, e algumas dessas crianças apresentarão problemas de ajustamento. Essa vulnerabilidade resulta de vários fatores, sendo importante considerar que a resposta da criança pode, em parte, resultar do seu temperamento, de sua capacidade intelectual, ou de outras qualidades intraindividuais que 


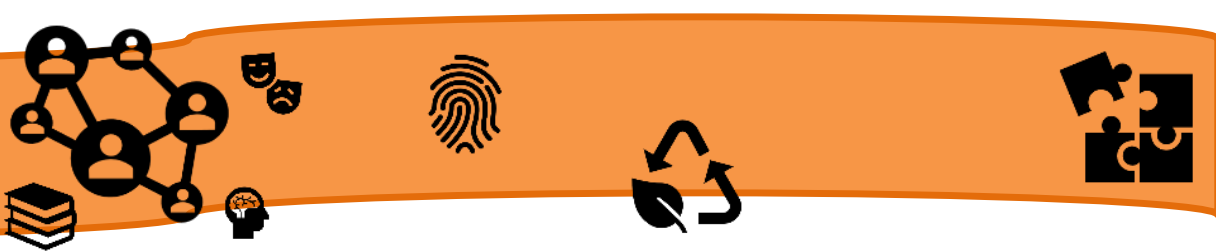

são mediadoras do grau de ajustamento a curto e longo prazos. A violência não ocorre isolada, ela é parte de uma constelação de outros fatores reconhecidos por afetarem o desenvolvimento da criança [...]. (BRANCALHONE, 2004, p. 114).

Assim, as crianças podem apresentar diferentes formas de comportamento, uma vez que estão sujeitas a todos os tipos de violência e agressão, e esse comportamento varia de acordo com o gênero, e tem várias formas de consequências que surgem a partir da violência, doméstica ou não.

\section{CARACTERÍSTICAS DA AGRESSIVIDADE}

Comportamento agressivo é próprio da espécie humana e apresenta múltiplas configurações. Ele pode ser expresso através de movimentos de ataque ou fuga; pela via emocional, com a experimentação de sentimentos de raiva e ódio; pela via somática, como a apresentação de taquicardia, rosto ruborizado, além das demais reações autonômicas; e finalmente, a via verbal, da qual o indivíduo vai utilizar-se do sentido das palavras para expressar controle em relação aos outros (FARIZ; MIAS; MOURA, 2005).

Essa abordagem da agressão refere-se à agressão instrumental, ou seja, aquela que apresenta uma função dentro do ambiente em que está sendo utilizada. Isso significa que o indivíduo tenta obter o controle de seu meio através de comportamentos agressivos, tais como gritar, ameaçar, quebrar ou xingar (FARIZ; MIAS; MOURA, 2005).

A partir dessa definição, pode-se observar que, ao longo do processo de maturação, crianças e adolescentes exibem comportamentos agressivos. Entretanto, se essas condutas se mostram severas e frequentes, elas podem indicar sinais de psicopatologia (KENDALL, 1991).

- Transtorno da Personalidade Passivo-Agressiva;

- Transtorno da Personalidade Negativista.

A característica essencial é um padrão invasivo de atitudes negativistas e resistência passiva às exigências de desempenho adequado em situações sociais e ocupacionais, que começa no início da idade adulta e ocorre em uma variedade de contextos. 


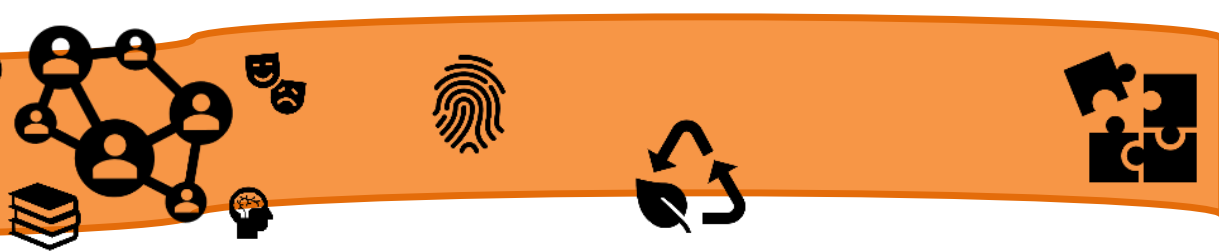

Estes indivíduos habitualmente ressentem, opõem-se e resistem às exigências de que funcionem em um nível esperado pelos outros. Esta oposição ocorre mais frequentemente em situações ocupacionais, mas também pode se manifestar no funcionamento social. A resistência é expressa por procrastinação, esquecimento, teimosia e ineficiência intencional, especialmente em resposta às tarefas designadas por figuras de autoridade. Por exemplo, quando um executivo dá a algum subordinado algum material a ser estudado para uma reunião na manhã seguinte, este pode extraviar o material ou arquivá-lo em local incorreto, ao invés de apontar a insuficiência de tempo para fazer o trabalho. Esses indivíduos sentem-se trapaceados, desconsiderados e incompreendidos. Eles podem ser mal-humorados, irritáveis, impacientes, propensos a discussões, céticos e "do contra".

As figuras que representam autoridade, como por exemplo, um superior no emprego, um professor na escola, um dos pais ou um cônjuge que representa o papel de pai/mãe, frequentemente se tornam o foco da insatisfação. Em vista de seu negativismo e tendência a externalizarem a culpa, esses indivíduos frequentemente criticam e verbalizam hostilidade para com figuras de autoridade, à menor provocação. Eles também sentem inveja e demonstram ressentimento com colegas que tiveram sucesso ou que são vistos de maneira positiva por figuras de autoridade.

Além disso, estes indivíduos frequentemente se queixam acerca de seus infortúnios pessoais. Eles têm uma visão negativa do futuro e podem fazer comentários do tipo: "Fazer o bem não compensa" e "O que é bom dura pouco". Estes indivíduos podem oscilar entre a expressão de um desafio hostil a quem veem como causadores de seus problemas e uma tentativa de apaziguar essas pessoas, pedindo perdão ou prometendo sair-se melhor no futuro.

Comportamento passivo-agressivos são encontrados com frequência na vida cotidiana, particularmente entre os indivíduos em contextos autoritários, como por exemplo, trabalho, serviço militar e prisões, que não toleram outras formas de afirmação. Apenas quando são inflexíveis, mal adaptativos e causam prejuízo funcional clinicamente significativo ou sofrimento subjetivo. Estes traços de personalidade passivo-agressiva constituem um transtorno.

\section{AÇÕES PREVENTIVAS CONTRA A AGRESSIVIDADE}




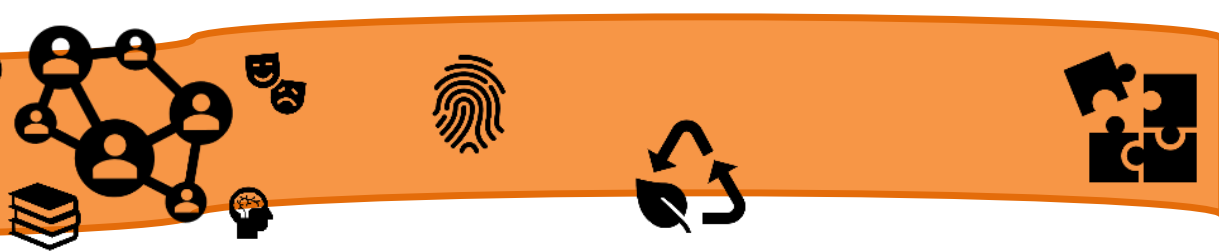

A agressividade representa um dos principais fenômenos que geram dificuldades no contexto escolar. Esse fato vem se agravando de tal forma que, nem a escola e nem a família conseguem solucionar o problema.

Partimos do pressuposto que, se desejamos intervir na realidade educacional, devemos conhecer a forma como os sujeitos que estão envolvidos nessa realidade compreendem os dilemas que vivenciam e às alternativas de modificação desta situação. Piaget (1977, p. 435) define as normas morais "como regras racionais de acordo mútuo". Uma norma é boa quando satisfaz as "leis da reciprocidade" e para reconhecer se uma norma é boa, a criança "terá de colocar-se numa perspectiva que se harmonize com outras perspectivas".

Não é um problema que poderá ser resolvido de forma isolada, somente abrangendo a esfera escolar. Faz-se necessário uma aproximação maior entre a escola, a família e as esferas públicas, como o conselho tutelar, as promotorias de infância e de adolescência, visando um trabalho integrado, não apenas discutindo as dificuldades existentes no contexto escolar, mas com a inserção destes novos olhares possibilitarem uma ressignificação das formas e modelos de intervenção neste contexto para resolver ou amenizar esse problema.

Convém analisarmos que os professores, muitas vezes, não se encontram bem preparados para lidar com os conflitos que possam surgir com os alunos, não dando chances para que as novas relações entre educadores e alunos possam ser estabelecidas de maneira distinta.

Sabemos a importância de uma análise da equipe e de qualificações constantes para melhor desempenhar o papel de educadores. A reciclagem é uma das principais ações que as escolas deveriam ofertar aos seus profissionais. Enfim, a questão dos relacionamentos entre professores e alunos não deixa de ser um tema de Educação Preventiva. Assim, deve estar em constante pauta de trabalho e aperfeiçoamento pelas equipes docentes das entidades de ensino. "lutar pela alegria na escola é uma forma de lutar pela mudança no mundo" (SNYDERS, 1995, p. 10).

\section{ABORDAGEM DOS TEMAS TRANSVERSAIS}

Entre as medidas que deveriam ser adotadas em uma escola para enfrentar os problemas de convivência, sem renunciar aos princípios de compreensão e de escola 


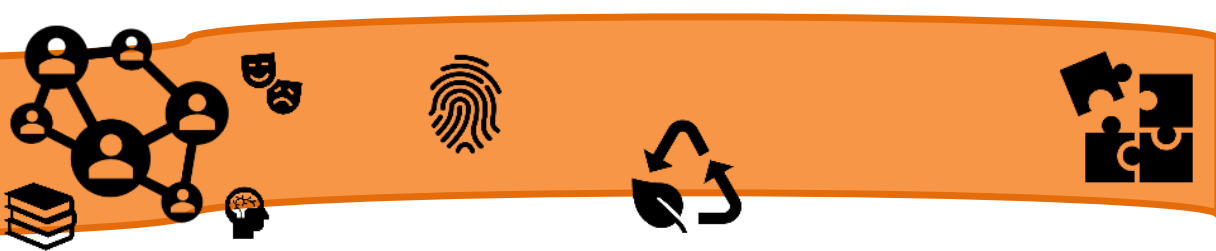

d) Educação democrática: devido a que grande parte da atitude violenta ou indisciplinada de determinados alunos representa uma ponta de iceberg de mal-estar, pela imposição autoritária de normas por parte da instituição escolar. Diante disto, a educação democrática promoverá a participação a partir do estabelecimento das próprias normas de convivência e seu controle, até o planejamento do currículo no contexto de uma negociação que leve em consideração as exigências da sociedade e seus próprios interesses.

e) Educação moral: como transversal de todos os temas, uma vez que promove a reflexão e o julgamento moral em torno de determinadas situações dilemáticas que estão presentes no desenvolvimento de todos os temas. Procura melhorar o conhecimento dos valores-meta e o desenvolvimento de uma ética pessoal para se movimentar em sociedade.

\section{CONSIDERAÇÕES FINAIS}

Este trabalho procura analisar a problemática da agressividade no contexto escolar, avaliando vários aspectos e favorecendo mudanças conceituais. As definições encontradas são várias, entre as quais conta-se a de Abreu (1998), que aponta para a capacidade de provocar malefícios ou prejuízos, materiais ou morais, a outrem ou a si.

Através de uma breve pesquisa bibliográfica, surge uma multiplicidade de conceitos diferentes tentando definir comportamentos agressivos. Também evidencia que as principais fontes de estilos de comportamento agressivo na criança "são as agressões modelada e reforçada pela família" (BANDURA, 2008, p. 99). Ou seja, o comportamento agressivo apresentado pela criança no contexto escolar pode ser considerado reflexos, reprodução ou até mesmo devolução da violência sofrida no ambiente familiar, da qual a criança é a primeira vítima, onde está exposto a fatores de risco e parece não apresentar rede protetora suficiente para minimizar esses efeitos.

As condutas agressivas podem aparecer em vários contextos: na família, entre os amigos, nas escolas. No âmbito escolar, este fenômeno tem vindo assumir preocupações alarmantes, sendo necessária uma reflexão sobre as práticas educativas, o rendimento escolar e o papel da escola na sociedade. Neste sentido faz se necessário, portanto, a reestruturação da família fundamentada em relações entre pai e filho, que possibilite mudança nos comportamentos não só da criança mais em toda a família. 


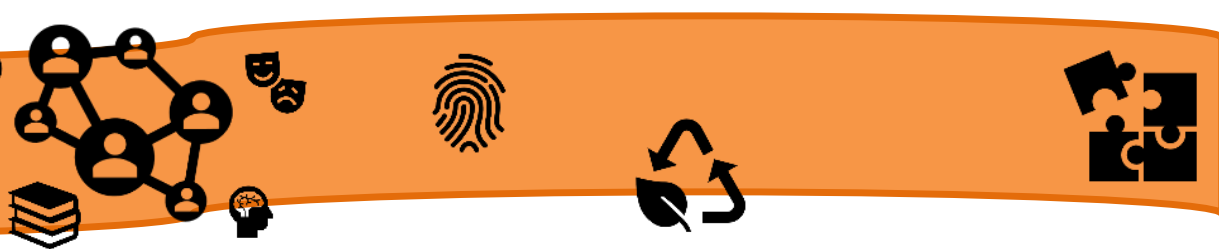

Considerando-se os aspectos acima mencionados, a respeito da importância da família para o desenvolvimento da criança, bem como a questão do ciclo de vida familiar, pode-se dizer que as experiências vivenciadas pela criança, tanto no contexto familiar quanto em outros ambientes nos quais ela está inserida, contribuem diretamente para a sua formação, possibilitando um aprendizado essencial para a sua atuação futura. É importante encontrar formas de avaliar este fenômeno, mesmo os autores inatistas assumem que é possível haver alguma capacidade de controle sobre as pulsões agressivas.

A pesquisa colabora para o aprendizado acerca da prática pedagógica institucional. Portanto, a realização deste trabalho fornece base para atuar de forma preventiva, a fim de compreender os processos de desenvolvimento das aprendizagens humanas, recorrendo a várias estratégias com objetivo de intervir na problemática que esteja atravancando o processo de ensino-aprendizagem do indivíduo.

Diante disso, percebe-se que, a resolução de problemas é um grande desafio para aqueles que estão envolvidos com o processo educativo de crianças, jovens e adolescentes. É preciso que a escola e a família busquem cada vez mais uma relação de parceria, com compromisso, a fim de superar as dificuldades existentes, com relação à agressividade.

Embora os resultados apontem para uma correlação entre o comportamento antissocial da criança e o modelo familiar ao qual ela faz parte, vale ressaltar que esse fator não pode ser considerado isolado, uma vez que outras fontes geradoras de violência podem influenciar diretamente na má conduta desta criança. A precária condição socioeconômica, o contexto escolar, onde muitas vezes o aluno pode usar a agressão como um recurso contra o autoritarismo do professor, o meio social e cultural e o preconceito recebido por elas, são fatores causadores potenciais das agressões em sua vida, onde a desigualdade social, por si só, já é agressiva, e não oferece oportunidades a esta criança.

Este tema foi pesquisado para contribuir com uma aprendizagem de qualidade, partindo do pressuposto de que não existe qualidade em um ambiente com agressividade. Faz-se necessário buscar novos caminhos que levem a família, a equipe pedagógica, os professores e os alunos a assumirem o seu verdadeiro papel neste processo. 


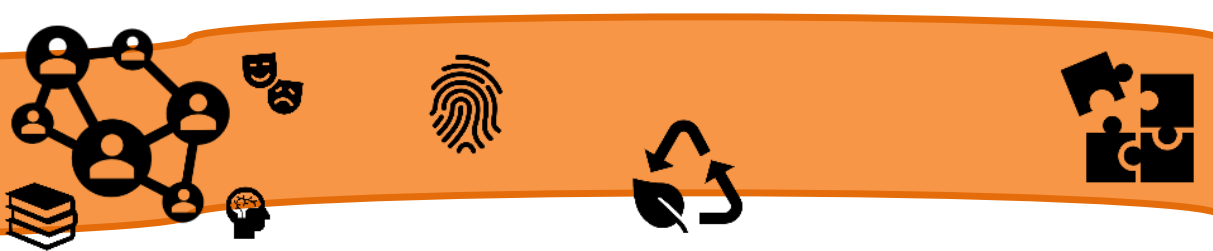

As famílias, por diversos motivos, vêm se excluindo de suas responsabilidades na educação escolar de seus filhos, quanto a valores éticos e sociais, deixando essa responsabilidade à escola.

Nota-se que, assim como a agressividade, a indisciplina passou a ser um dos maiores problemas pedagógicos enfrentados pelos educadores na atualidade, dificultando todo processo educativo dentro da sala de aula. É importante salientar que, no processo ensino-aprendizagem existem metodologias e práticas que devem proporcionar uma atuação eficiente e eficaz do professor.

São inúmeros os fatores que contribuem para o fracasso escolar, a identificação e intervenção são formas de diminuir esses fatores. É importante a identificação correta do problema para melhor decisão do que fazer e de quem intervir. A intervenção deve ser precisa e multidisciplinar, pois existem várias áreas que contribuem na resolução do problema ou pelo menos na diminuição deste.

Ser um bom profissional hoje, no mundo globalizado e competitivo, requer muita dedicação nos estudos e boas Especializações, e a Psicopedagogia, assim como outros cursos de especialização serve para contribuir ainda mais para o crescimento pessoal e profissional.

\section{REFERÊNCIAS}

ABREU, M. V. Cinco ensaios sobre a motivação. Coimbra: Almedina, 1998.

AZEVEDO, M. A.; GUERRA, V. Violência doméstica na infância e na adolescência. São Paulo: Robe, 1995.

BANDURA, Albert. Teoria social cognitiva: conceitos básicos. Porto Alegre: Artmed, 2008.

BRANCALHONE, G. P. (2004). Criança exposta à violência: avaliação do desempenho acadêmica. Psicologia: teoria e pesquisa.

FARIZ, M.; MIAS, C.; MOURA, C. B. Comportamento agressivo e terapia cognitivo-comportamental na infância. São Paulo: Santos Editora, 2005.

HUTZ, C. S. Violência e Risco na Infância e Adolescência: pesquisa e Intervenção. São Paulo: Casa do Psicólogo, 2005.

KENDALL, P. C. Child \& Adolescent Terapy: cognitive-Behavorial Procedures. New York: Guil Ford Press, 1991. 
KOLLER, S. Ecologia do Desenvolvimento Humano. São Paulo: Casa do psicólogo, 2004.

LISBOA, C, S. M; KOLLER, S. H. Construção da Validação de Conteúdo de uma Escala de Percepção por professores dos Comportamentos Agressivos de Crianças na Escola. Psicologia em Estudo de Caso. 2001.

LOPES, Patrícia. Agressividade na escola. Brasil Escola, 2011. Disponível em: http://educador.brasilescola.com/comportamento/agressividade-na-escola.htm>. Acesso em: 13/04/2020.

MARCELOS, Viviane Avelino. A violência na escola. Brasil Escola. 2011.

PIAGET, Jean. O julgamento moral na criança. São Paulo: Editora Mestre Jou, 1977.

PIMENTA, Selma Garrido. (org.) Formação de professores: Identidade e saberes da docência. In. Saberes Pedagógicos e Atividades Docentes. São Paulo: Cortez, 2002.

SILVA, M. E. P. Burnout: por que sofrem os professores? Estudos e Pesquisas em Psicologia, 2006.

SISTO, F. F. Aceitação-rejeição para estudar a agressividade nas escolas. Psicologia e Estudos, 2005, 10(1), 117-125.

SNYDERS, Georges. Feliz na universidade: estudo a partir de algumas biografias. Rio de Janeiro: Editora Paz e Terra, 1995. 


\title{
ALFABETIZAÇÃO E LETRAMENTO: METODOLOGIAS APLICADAS EM
}

\section{ANOS INICIAIS}

\author{
MELO, Igor Alessandro da Silva ${ }^{6}$ \\ MELO, Jakeline Olegário de ${ }^{7}$ \\ TEMOTEO, Marlice Lígia Martins ${ }^{8}$ \\ COSTA, Ivanilson Sousa da ${ }^{9}$
}

\section{RESUMO:}

Em uma sociedade com tantas diferenças culturais, é importante que as crianças sejam incluídas nos processos de alfabetização e letramento, aprendizagens indispensáveis a eles, as quais dependem da língua oral e da escrita contextualizada. Quando o assunto é alfabetização e letramento, encontramos alguns teóricos que explicam bem as práticas de leitura e escrita no processo de alfabetização e letramento. Para elaborar este artigo buscou-se por Magda Soares (2003; 2004; 2008; 2010) e Paulo Freire (1992), ela afirma que a alfabetização deve se desenvolver em um contexto de letramento a partir do início da aprendizagem da escrita, como desenvolvimento de habilidades de uso da leitura da escrita. Destaca ainda que as práticas sociais que envolvem a língua escrita, devem estar presentes na escola de forma contextualizada para que as crianças tenham uma aprendizagem significativa. Este trabalho tem o objetivo de explorar os conceitos de alfabetização e letramento e os métodos mais utilizados e mais eficientes. Conclui se que a qualidade da educação nas turmas de alfabetização é possível, através de metodologias diferenciadas, que proporcionem o desenvolvimento da alfabetização e do letramento de cada aluno.

PALAVRAS-CHAVE: Letramento. Alfabetização. Metodologias. Aprendizagem. Aluno.

\section{INTRODUÇÃO}

A discussão sobre alfabetização vem crescendo nos últimos anos com objetivo de diminuir os resultados de analfabetismo, um problema ainda presente em nosso Brasil.

\footnotetext{
${ }^{6}$ Mestrando em Ciências da educação pelo Centro de Educação Continuada e Aperfeiçoamento Profissional (CECAP). Professor da Educação Básica do município de Guamaré/RN. E-mail: igsmelos@gmail.com

${ }^{7}$ Especialista em Fisiologia do Exercício pelo Instituto de Educação de Pesqueira/PE (IESP). Professora de Educação Básica. E-mail: jakelinecirnemacau @gmail.com

${ }^{8}$ Especialista em Meio Ambiente e Sustentabilidade pela Faculdade do Vale Elvira Dayrell (FAVED). Professora da Rede Privada do município de Macau/RN. E-mail: marliceligia @ hotmail.com

${ }^{9}$ Especialista em Esportes Coletivos na Escola pela Universidade do Estado do Rio Grande do Norte (UERN). Professor de Educação Física do município de Macau/RN. E-mail: ivanilsonsousa_2012@hotmail.com
} 


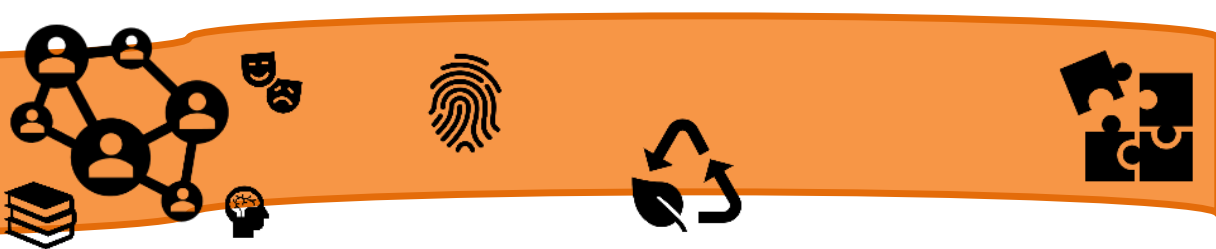

No início da escolarização, a leitura se desenvolveu através de métodos que possibilitassem alcançar resultados satisfatórios, aprendendo a ler e a escrever. Então, surgiram alguns métodos de alfabetização, todos com o mesmo objetivo, a aprendizagem do aluno na leitura e escrita. Porém, estes métodos eram trabalhados dentro de uma metodologia abstrata, fora de contexto para o aluno, dificultando assim, a aprendizagem.

Os métodos eram muito mecânicos, sem contextualização, o método sintético (alfabeto ou soletração, fônico, silábico) e o método analítico (palavração, sentenciação, conto ou texto).

Apesar desses métodos serem diferentes em procedimentos metodológicos, existe entre eles uma ideia de igualdade, nenhum deles valoriza os conhecimentos informais que o aluno possui da escrita. Nenhum dos métodos utiliza a experiência de ideias e hipóteses sobre a escrita, que o aluno construiu antes de entrar na escola e ser alfabetizada. Esses métodos têm a mesma característica de desconsiderar a capacidade que o aluno tem de formular hipóteses, analisar a escrita e usar diferentes estratégias no processo de descoberta; deixando de fora as questões ligadas a funcionalidades da escrita.

Segundo Soares (2004), a questão do método de alfabetização ainda constitui um impasse na área do ensino e da aprendizagem da língua escrita. Acredita - se que nos iludimos, por muito tempo, quando julgamos que muitos estejam se interrogando sobre a importância de um método de alfabetização: talvez a grande maioria daqueles que estão envolvidos na prática cotidiana da alfabetização continuem afirmando a busca de um método, a pergunta que se fazem, que continuam fazendo é, certamente, qual é o método; fônico? Global? Silábico? Qual é o mais eficiente? Embora nenhum deles trabalhe na concepção do letramento. Então como fica a aprendizagem nesse caso?

Atualmente, nenhum processo de alfabetização é tão eficiente se não estiver atrelado ao letramento. Em todas as metodologias aplicadas, o letramento precisa esta presente dando significado à aprendizagem para o aluno.

Hoje acredita-se que a busca pelo método de alfabetização deve partir de um pressuposto que devemos ensinar a leitura e a escrita de maneira que possamos interagir com os alunos de forma dinâmica, que eles possam aprender e compreender. Isso não 
implica dizer qual o melhor método de ensino empregado atualmente, mas mostrar que cada método apresentado desenvolve no aluno determinadas capacidades.

Soares (2008, p. 20) afirma que,

[...] só recentemente passamos a enfrentar essa nova realidade social em que não basta saber ler e escrever, é preciso também fazer uso do ler e do escrever, saber responder as exigências de leitura e de escrita que a sociedade faz continuamente - daí o surgimento do termo letramento.

\section{ALFABETIZAÇÃO E LETRAMENTO: METODOLOGIAS APLICADAS EM ANOS INICIAIS}

Pensar em alfabetização atualmente requer um pensamento sob a ótica social e a partir de normas e regras cultas, as quais devem ser ensinadas na escola, para formar um cidadão com habilidades de compreender o mundo e de comunicar com ele em todas as situações.

Para Magda Soares (2010, p. 93) o processo de leitura e de escrita, de alfabetização tem como definição "a soma de ações, um conjunto de princípios e hipóteses psicológicas, linguísticas, pedagógicas que respondem a objetivos determinados".

Para compreender o letramento, é essencial estudar os fundamentos e pressupostos teóricos de Freire (1992) e Soares (2003), em que as teorias nos auxiliam na compreensão da importância do letramento ligado as vários métodos de alfabetização, o qual não basta o aluno aprender ler e escrever, mas é necessário que ele desenvolva competência e habilidade de interpretar e produzir textos diversos, através de uma contextualização para que seja compreendido o sentido da aprendizagem.

Para que o professor alcance seu objetivo de alfabetização com sucesso, é importante que ele domine os conceitos de alfabetização e letramento e as contribuições de cada uma na aprendizagem dos alunos, então, veremos como esses conceitos estão interligados e são indissociáveis na prática pedagógica.

Enquanto o sujeito alfabetizado sabe codificar e decodificar o sistema de escrita, o sujeito letrado vai além, sendo capaz de dominar a língua no seu cotidiano, nos mais distintos contextos. Para melhor compreender o trabalho de alfabetização e letramento segue um quadro explicativo: 
Alfabetização

Letramento

\begin{tabular}{|l|l|l|}
\hline Conceito & $\begin{array}{l}\text { Alfabetização é o processo de } \\
\text { aprendizado da leitura e da escrita. }\end{array}$ & $\begin{array}{l}\text { Letramento é o desenvolvimento do } \\
\text { uso competente da leitura e escrita } \\
\text { nas práticas sociais. }\end{array}$ \\
\hline Uso & Uso individual da leitura e escrita. & Uso social da leitura e escrita. \\
\hline Individuo & $\begin{array}{l}\text { Alfabetizado é o sujeito que sabe ler e } \\
\text { escrever. }\end{array}$ & $\begin{array}{l}\text { Uma pessoa letrada sabe usar a } \\
\text { leitura e a escrita de acordo com as } \\
\text { demandas sociais. }\end{array}$ \\
\hline $\begin{array}{l}\text { Atividades } \\
\text { envolvidas }\end{array}$ & $\begin{array}{l}\text { Codificar e decodificar a escrita e } \\
\text { os números. }\end{array}$ & $\begin{array}{l}\text { Organizar discursos, interpretação } \\
\text { e compreensão de textos, reflexão. }\end{array}$ \\
\hline Ensino & $\begin{array}{l}\text { Deixa o indivíduo apto a desenvolver } \\
\text { os mais diversos métodos de }\end{array}$ & $\begin{array}{l}\text { Habilita o sujeito a utilizar a escrita e } \\
\text { a leitura nos mais diversos contextos. }\end{array}$ \\
\hline
\end{tabular}

Um indivíduo alfabetizado não significa necessariamente um indivíduo letrado. Do mesmo modo, um sujeito pode ser capaz de realizar determinadas atividades em seu cotidiano que necessitem do letramento, como preencher um recibo sem que ele seja alfabetizado. Todas estas práticas exigem que o aluno tenha sido alfabetizado e letrado.

O crescimento social trouxe uma nova exigência à escola, a produção de novos conhecimentos e de novas tecnologias, e como consequência, novas exigências sociais para aprendizagem dos alunos.

Uma aprendizagem mais crítica e mais democrática que necessita de outro conceito de alfabetização, um conceito mais amplo que proporciona ao aluno a leitura de mundo, em que esse aluno tem habilidades diversas para exercer sua cidadania na sociedade, que ele tem a ousadia de interagir e agir como cidadão de história e conceitos.

Para que o aluno tenha essa nova concepção de aprendizagem o professor precisa ser habilitado e sempre buscar uma formação continuada para que possa estar sempre aprendendo e ensinado, assim a mudança de paradigma da alfabetização é mudada automaticamente, sem prejuízo aos alunos e aos professores. 


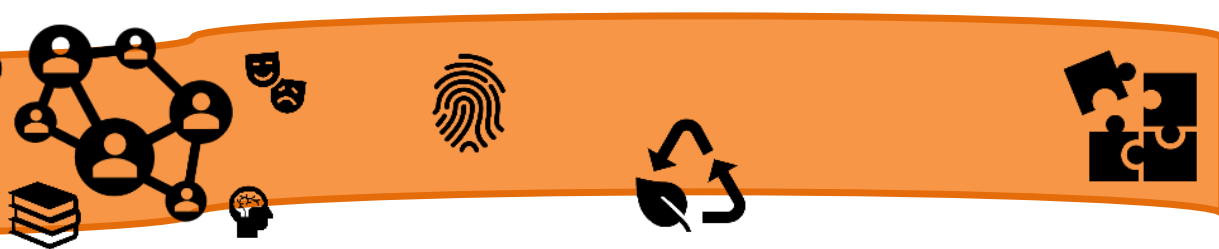

Os fundamentos da alfabetização e letramento ocorrem a partir de um trabalho de sensibilização e de atividades específicas à linguagem, sendo a escrita e sua função social, desta forma, todo aluno alfabetizado precisa compreender textos escritos e/ou sua função, caso contrário torna-se sem sentido. Também devem ter claras intenções, significados, ilusões e fantasias, por esse motivo, utilizou-se o termo Letramento para aprender. Para Soares (2010, p. 18), letramento é:

[...] palavra recém-chegada ao vocabulário da Educação e das Ciências Linguísticas: é na segunda metade dos anos 80 , há cerca de apenas dez anos, portanto, que ela surge no discurso dos especialistas dessas áreas. [...] O que explica o surgimento recente dessa palavra? Novas palavras são criadas (ou a velhas palavras dá-se um novo sentido) quando emergem novos fatos, novas ideias, novas maneiras de compreender os fenômenos. [...] Letramento é, pois, o resultado da ação de ensinar ou de aprender a ler e escrever: o estado ou a condição que adquire um grupo social ou um indivíduo como consequência de ter-se apropriado da escrita. (grifos nossos).

Os Parâmetros Curriculares Nacionais (BRASIL, 1998) defendem a proposta construtivista como método de alfabetização, destacando a valorização do conhecimento que o aluno trás para escola ao iniciar o processo de alfabetização. Nesta perspectiva, o letramento está associado à aprendizagem, quando compreende o contexto do conteúdo, ensinado e como ele pode ser útil no dia a dia.

A escola precisa abrir espaço para o letramento, pois só assim os alunos irão adquirir competências para desempenhar o papel de cidadão no contexto social. Não existe método de alfabetizar melhor ou pior, existe um contexto que precisa fazer parte da vida do aluno.

Concordando, com Magda Soares (2003), em seu artigo Letramento e Alfabetização: as muitas facetas, a ampliação do significado de alfabetização em direção ao conceito de letramento, levou à perda de sua especificidade.

[...] no Brasil a discussão do letramento surge sempre enraizada no conceito de alfabetização, o que tem levado, apesar da diferenciação sempre proposta na produção acadêmica, a uma inadequada e inconveniente fusão dos dois processos, com prevalência do conceito de letramento, $[\ldots]$ o que tem conduzido a um certo apagamento da alfabetização que, talvez com algum exagero, denomino desinvenção da alfabetização [...]. (SOARES, 2003, p. 8 - grifos nossos) 


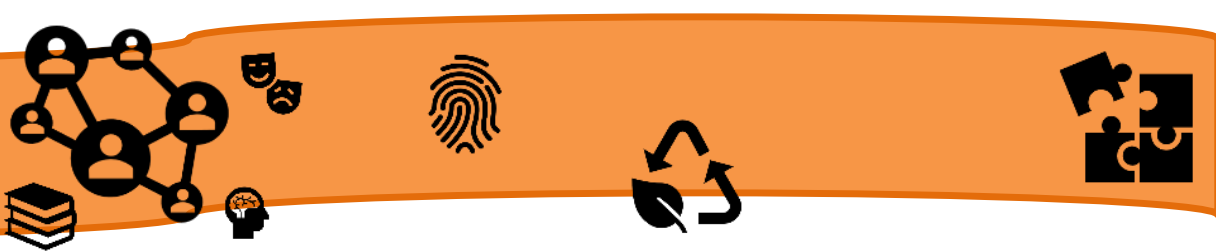

Todavia, é essencial que a prática pedagógica seja planejada a partir dos conhecimentos prévios dos alunos, e que os professores iniciem o trabalho fazendo um diagnóstico do conhecimento para saberem de onde devem partir e planejar suas atividades de alfabetização e letramento.

Sabe-se que o aluno nas suas relações cotidianas entra em contato com uma diversidade de informações que através delas pode criar uma leitura de mundo particularizada. Nesse sentido, a prática pedagógica deve estar voltada à alfabetização em anos iniciais, oportunizando o alcance de níveis qualitativos de aprendizagem e letramento.

\section{CONCLUSÃO}

Diante desta pesquisa, concluiu-se que os processos de alfabetização se modificaram ao longo dos anos a fim de alcançar os interesses sociais de cada época. Desde o método tradicional, ao conceito de alfabetização e letramento, atuais, as letras sempre foram apresentadas cumprindo seu papel social de comunicação oral e escrita na sociedade.

É importante destacar que os alunos não aprendem ao mesmo tempo, o professor não alcança um desenvolvimento linear em sua turma, e nenhum método é tão eficiente quanto o letramento, por isso é necessário que a alfabetização seja iniciada a partir do conhecimento prévio do aluno, o qual deve ser contextualizado dentro da proposta pedagógica.

Outra questão relevante dentro da alfabetização, são os professores alfabetizadores, pois eles precisam estar habilitados, serem competentes, criativos e terem compromisso com a formação dos alunos como cidadãos comprometidos com a transformação social.

Enfim, acredita-se que é possível, alcançar a competência na educação das turmas de alfabetização, com metodologias que proporcionem tanto o desenvolvimento da alfabetização quanto o desenvolvimento do letramento de cada aluno, para que possam ser autores de sua vida e de transformações.

A pesquisa mostrou que, atualmente, a educação está exigindo uma alfabetização com letramento, e que no processo de alfabetizar e letrar é importante que os professores conheçam os dois conceitos, sendo a alfabetização um processo especifico e 
indispensável de domínio da escrita, e assim a conquista dos princípios alfabético e ortográfico favorecem ao aluno o ato de ler e escrever com autonomia.

O letramento é o processo de participação na cultura escrita, processo que se inicia quando a criança começa a conviver com as diferentes situações da escrita na sociedade e aumenta ao longo da vida, com a possibilidade de participar das práticas sociais que envolvem a língua escrita, tornando-o autônomo.

\section{REFERÊNCIAS}

BRASIL. Parâmetros Curriculares nacionais (PCNs). Ensino Fundamental. Anos Iniciais. Brasília: MEC/SEF, 1998.

FREIRE, P. Pedagogia da Esperança: um reencontro com a Pedagogia do Oprimido. Rio de Janeiro: Paz e Terra, 1992.

SOARES, Magda. Letramento e alfabetização: as muitas facetas. Trabalho apresentado na $26^{\circ}$ Reunião Anual da ANPED, Minas Gerais, 2003.

SOARES, Magda. Letramento e escolarização. In: Letramento no Brasil, reflexões a partir do INAF 2001 (org.) Vera Massagão Ribeiro - 2 ${ }^{\mathrm{a}}$ Ed. - São Paulo, Global, 2004.

SOARES, Magda. Alfabetização e Letramento. $5^{\text {a }}$ ed., São Paulo: Contexto, 2008. Editora, 2010.

Letramento: um tema em três gêneros. $4^{\mathrm{a}}$ Ed., Belo Horizonte: Autêntica

https://www.diferenca.com/alfabetizacao-e-letramento. 


\title{
AUTONOMIA NA EDUCAÇÃO INFANTIL: DISCUSSÕES TECIDAS ENTRE OS DOCUMENTOS NACIONAIS E A PEDAGOGIA FREIREANA
}

\author{
SALVI, Luciana Rita Bellincanta ${ }^{10}$ \\ ALVES, Solange Maria ${ }^{11}$
}

\begin{abstract}
RESUMO:
Desde cedo as crianças são incentivadas a optar, fazer escolhas participarem ativamente das decisões acerca de situações que emergem no contexto ao qual estão inseridas. A discussão do tema da autonomia em Freire, com vistas às contribuições na Educação Infantil, apresentada nesse artigo, foi desenvolvida na Universidade Federal da Fronteira Sul (UFFS), no Programa de Pós-Graduação em Educação (PPGE)- Mestrado, na linha de Conhecimento e Desenvolvimento nos Processos Pedagógicos, sendo vinculada ao projeto de pesquisa: A pedagogia crítica freireana e processos educativos. São essas experiências sociais, vivenciadas em contextos formais ou não formais, que possibilitam a construção gradativa e a apropriação da autonomia, uma vez que ela é promotora da participação e do engajamento social, da libertação, do exercício da cidadania e da libertação. O estudo, em tela, propõe uma reflexão crítica sobre a promoção da autonomia do sujeito no âmbito da práxis pedagógica com a infância na perspectiva da Pedagogia Freireana, utilizando o referencial teórico da obra de Paulo Freire como aporte teórico principal do objeto de estudo, que neste trabalho, é cotejado com a Base Nacional Comum Curricular (BNCC), com as DCNEI, e com os Referenciais Curriculares Nacionais para a Educação Infantil (RCNEI), configurando assim num estudo bibliográfico e documental. O movimento de análise realizado, apontam para os avanços históricos alcançados por meio da instituição dos documentos nacionais curriculares, bem como, para a relevância das contribuições de Freire para a Educação Infantil, sendo estas, comprometidas com o desenvolvimento e a promoção da criança autônoma.
\end{abstract}

PALAVRAS-CHAVE: Autonomia na Educação Infantil. Pedagogia Freireana. BNCC. DCNEI. RCNEI.

\section{INTRODUÇÃO}

A Educação Infantil, primeira etapa da Educação Básica, é um período da vida da criança, no qual ocorrem grandes transformações, tendo em vista a promoção de

\footnotetext{
${ }^{10}$ Mestra em Educação pela Universidade Federal da Fronteira Sul (UFFS). Agência de fomento: Programa de Bolsas Universitárias de Santa Catarina (UNIEDU). Orientadora educacional na Escola Básica Municipal Santa Cruz, Concórdia/SC. Atua com formação de professores da Educação Infantil. Email: luciana.salvi@gmail.com.

${ }^{11}$ Doutora em Educação com área de concentração em psicologia e educação pela Faculdade de Educação da Universidade de São Paulo (FEUSP). Docente no Programa de Pós-Graduação em Educação (PPGE) Mestrado na Universidade Federal da Fronteira Sul (UFFS), campus Chapecó/SC. E-mail: solange.alves@uffs.edu.br.
} 


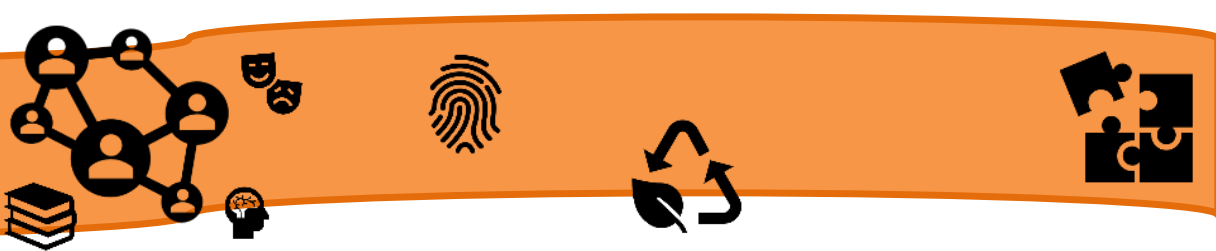

ações educativas que privilegiam o desenvolvimento integral nos aspectos afetivo, social, motor, físico e cognitivo.

As Diretrizes Curriculares Nacionais para a Educação Infantil (DCNEI) orientam um currículo voltado à promoção de práticas educativas que articulem as experiências e saberes que as crianças carregam consigo, "[...] com os conhecimentos que fazem parte do patrimônio cultural, artístico, ambiental, científico e tecnológico". (BRASIL, 2009, art. $3^{\circ}$ ), respeitando a historicidade de cada uma, os direitos e as especificidades desse ciclo de desenvolvimento.

Nesse viés, desde cedo as crianças são incentivadas a optar, fazer escolhas participarem ativamente das decisões acerca de situações que emergem no contexto ao qual estão inseridas. São essas experiências sociais, vivenciadas em contextos formais ou não formais, que possibilitam a construção gradativa e a apropriação da autonomia, uma vez que ela é promotora da participação e do engajamento social, da libertação, do exercício da cidadania e da libertação.

O estudo, em tela, propõe uma reflexão crítica sobre a promoção da autonomia do sujeito no âmbito da práxis pedagógica com a infância na perspectiva da Pedagogia Freireana, utilizando o referencial teórico da obra de Paulo Freire como aporte teórico principal do objeto de estudo, que neste trabalho, é cotejado com a Base Nacional Comum Curricular (BNCC), com as DCNEI, e com os Referenciais Curriculares Nacionais para a Educação Infantil (RCNEI), configurando assim num estudo bibliográfico e documental.

O movimento de análise realizado, aponta para os avanços históricos alcançados por meio da instituição dos documentos nacionais curriculares, bem como, para a relevância das contribuições de Freire para a Educação Infantil, sendo estas, comprometidas com o desenvolvimento e a promoção da criança autônoma. A Pedagogia Freireana, resulta num aporte fundamental para a organização da práxis educativa com crianças, tendo em vista a construção de subjetividades livres, democráticas e solidárias, pautadas pela criticidade, alteridade e justiça social.

\section{REFERENCIAL TEÓRICO}

Nas inúmeras circunstâncias vivenciadas no cotidiano da Educação Infantil, emergem múltiplas possibilidades do educador promover uma prática educativa significativa que se volte à promoção da autonomia da criança. De acordo com o RCNEI (BRASIL, 1998, p. 39), “[...] o exercício da cidadania é um processo que se 


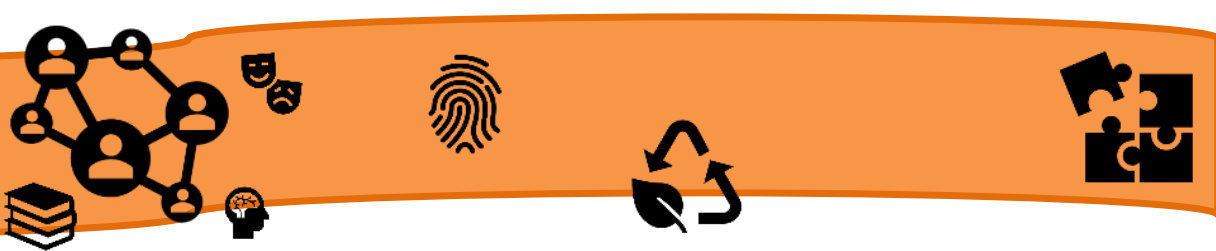

inicia desde a infância, quando se oferecem às crianças oportunidades de escolha e de autogoverno", o que, a nosso ver, coloca a autonomia como um princípio fundamental que sinaliza para a organização da Educação Infantil como espaço-tempo de exercício da cidadania que se constrói por meio da participação, do diálogo, da discussão, da contradição, da aceitação vivenciada nos espaços e nos tempos do cotidiano escolar. A autonomia desenvolve a responsabilidade sobre a tomada de decisão. Ela representa a conquista da independência e relaciona-se não somente aos cuidados físicos e ao bem estar, mas também a autonomia cognitiva do pensar, do experimentar, do descobrir e do aprender.

O documento sistematizado por vias do RCNEI (BRASIL, 1998, p. 39) preconiza ainda, que desde a tenra idade, a criança precisa desenvolver a capacidade para a realização de escolhas, sendo que estas perpassam os caminhos do acesso aos recursos e materiais existentes na sala de aula, até as opções de atividades a serem desenvolvidas, sendo assim "[...] podem-se criar situações em que as crianças fazem suas escolhas entre várias opções, em locais distintos ou no mesmo espaço", fortalecendo as interações sociais com os seus pares ou com crianças de diferentes faixas etárias, consistindo assim, na oferta de "[...] condições para que as crianças, conforme os recursos de que dispõem, dirijam por si mesmas suas ações" (BRASIL, 1998, p. 39), contribuindo assim, de maneira efetiva para o desenvolvimento das noções iniciais de responsabilidade sobre as escolhas e as ações praticadas.

Salientamos que uma proposta educativa que tem como um dos objetivos centrais, o desenvolvimento da criança autônoma, independente, com capacidade de iniciativa, que possua o autogoverno de suas ações coordenando-as com as ações dos outros, não se estrutura numa proposta autoritária, onde o adulto responsável, ou seja, o professor, é a principal voz ativa que centraliza o poder de decidir sobre o que e como fazer, onde fazer e com quem fazer, tampouco, uma prática educativa, alicerçada neste viés autoritário, que desconsidera as especificidades da infância que apregoam para uma prática educativa que respeite um corpo que tem a necessidade premente de se expressar por meio da fala, do movimento, das interações sociais e das brincadeiras e que impõe a este, a disciplina, o silêncio e a imobilidade exacerbadamente. Dessa forma, não há como conceber territórios de aprendizagem promotores do exercício da autonomia infantil. 
É pertinente destacar, que o fato da criança aprender a fazer sozinha determinadas ações, não resultam em garantia do desenvolvimento da autonomia, todavia a construção dela, perpassa pela realização de diversas situações, intencionadas pelo educador, que exerce um papel fundamental no sentido de promover a mediação, portanto compete a ele, a função essencial de ser o sujeito que "[...] organiza, sistematiza, e conduz situações de aprendizagem" (BRASIL, 1998, p. 39), planejando ações que mobilizem o auxílio, a contribuição e a participação da criança em ações de pequeno, médio e grande porte, respeitando as ações que a criança tem condições de fazer por conta própria, portanto, “[...] para favorecer o desenvolvimento da autonomia é necessário que o professor compreenda os modos próprios de as crianças se relacionarem, agirem, sentirem, pensarem e construírem conhecimentos” (Ibid, p. 40).

Corrobora com essa discussão Brasil (2009), ao assinalar que o currículo que estrutura a prática educativa, precisa se pautar em ações articuladoras das vivências e conhecimentos que a criança possui, portanto é vital para a prática educativa a estruturação em ações que posicionem a criança na condição de pivô central do planejamento curricular, ou seja, como um:

[...] sujeito histórico e de direitos que, nas interações, relações e práticas cotidianas que vivencia, constrói sua identidade pessoal e coletiva, brinca, imagina, fantasia, deseja, aprende, observa, narra e constrói sentidos sobre a natureza e a sociedade, produzindo cultura. (BRASIL, 2009, art. $4^{\circ}$ ).

Considerando que, a criança passa a estar no centro do processo de ensino e de aprendizagem e não mais o conteúdo, observamos a imprescindibilidade da construção da autonomia dela, no sentido de vivenciar plenamente as propostas educativas da Educação Infantil mediadas pelos educadores, uma vez que as DCNEI conferem indicativos dos princípios a serem respeitados. Quanto aos princípios éticos, o documento preconiza o desenvolvimento "[...] da autonomia, da responsabilidade, da solidariedade e do respeito ao bem comum, ao meio ambiente e às diferentes culturas, identidades e singularidades". (BRASIL, 2009, art. $6^{\circ}$, inciso I).

As DCNEI, apresentam as principais diretrizes para a efetivação da proposta pedagógica alinhando como eixos norteadores as interações sociais e a brincadeira em experiências que possibilitem, dentre elas, a vivência de “[...] situações de aprendizagem mediadas para a elaboração da autonomia das crianças nas ações de 


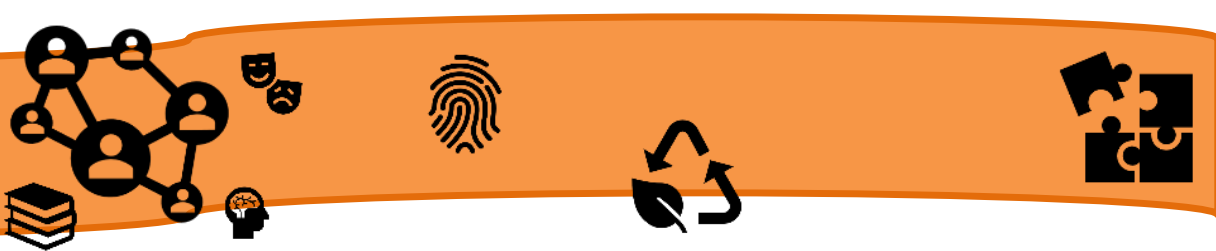

cuidado pessoal, auto-organização, saúde e bem-estar" (BRASIL, 2009, art. 9º inciso VI), todavia, este documento de orientação curricular não confere maiores indicativos de aprofundamento deste tema. Será no documento da BNCC que estas diretrizes são retomadas e acontece o alargamento das discussões curriculares a serem instituídas no âmbito da Educação Infantil.

Paralela à homologação realizada pelo Conselho Nacional de Educação (CNE) das DCNEI no ano de 2009, ocorreu a sexta reedição do material "Critérios para um atendimento em creches que respeite os direitos fundamentais das crianças" que sinaliza o respeito a criança, bem como aos direitos que possui, dentre eles o direito a brincadeira orientando que "[...] os adultos também acatam as brincadeiras propostas pelas crianças" (CAMPOS; ROSEMBERG, 2009, p. 14), ou ainda que, “[...] as salas onde as crianças ficam estão arrumadas de forma a facilitar brincadeiras espontâneas e interativas" (Ibid, p. 14).

Em relação ao direito à higiene e à saúde, observamos outras ações promotoras da autonomia que compreendem o direito a cuidar de si próprias e assumir responsabilidades em relação a sua higiene e saúde (Ibid, p. 19), quanto ao direito a desenvolver sua curiosidade, imaginação e capacidade de expressão, localizamos a importância de que os educadores auxiliem "[...] as crianças em suas tentativas de compreender as coisas e os acontecimentos a sua volta" (Ibid, p. 21).

$\mathrm{O}$ direito a expressar seus sentimentos preconiza às educadoras o compromisso em ajudar "[...] as crianças a desenvolver a sua autonomia" (CAMPOS; ROSEMBERG, 2009, p. 25), colocando em evidência as múltiplas interfaces educativas que são mediadas pelos educadores e que contribuem na promoção de sujeitos que se apropriam da autonomia, fazendo-se necessária a instituição de uma prática permeada pela intencionalidade pedagógica no intuito de assegurar a promoção do desenvolvimento integral da criança.

Ao dirigirmos a análise da construção da autonomia, para a BNCC (BRASIL, 2017), observamos que a autonomia deixa de ser caracterizada como um princípio ético até então categorizada nas DCNEI e passa a ser compreendida como uma competência geral a ser adquirida pelos educandos até o término da Educação Básica. O documento apresenta como definição para o conceito de competência a “[...] mobilização de conhecimentos (conceitos e procedimentos), habilidades (práticas cognitivas e 
socioemocionais), atitudes e valores para resolver demandas complexas da vida cotidiana, do pleno exercício da cidadania e do mundo do trabalho" (BRASIL, 2017, p. 08).

O enquadramento da autonomia como competência, somadas a outras nove competências, tem o intuito de promover a transformação da sociedade, tornando-a mais humana, justa e sustentável, pela ação dos sujeitos históricos formados pelas instituições formais de ensino e aprendizagem. A BNCC apresenta a autonomia como uma competência promotora nos educandos do "[...] agir pessoal e coletivamente com autonomia, responsabilidade, flexibilidade, resiliência e determinação, tomando decisões com base em princípios éticos, democráticos, inclusivos, sustentáveis e solidários”. (BRASIL, 2017, p. 10).

Frente ao exposto na BNCC, Brasil (2017), a etapa da Educação Infantil abarcará a realização de uma prática educativa pautada nas interações, na brincadeira e no desenvolvimento das competências gerais da Educação Básica, propondo assim seis direitos de aprendizagem e de desenvolvimento que contribuem com que a criança desempenhe um papel ativo em ambientes educativos com o intuito vivenciar situações desafiadoras e tentar resolvê-las, sendo: conviver, brincar, participar, explorar, expressar e conhecer-se. Dentre estes direitos, abrangeremos especificamente o direito que estabelece maiores aproximações com a discussão da autonomia, que é o direito de:

[...] participar ativamente, com adultos e outras crianças, tanto do planejamento da gestão da escola e das atividades propostas pelo educador quanto da realização das atividades da vida cotidiana, tais como a escolha das brincadeiras, dos materiais e dos ambientes, desenvolvendo diferentes linguagens e elaborando conhecimentos, decidindo e se posicionando. (BRASIL, 2017, p. 36, grifo do autor).

Neste sentido, é possível estabelecermos conexões com a necessidade de consolidarmos uma intencionalidade educativa para assegurar o desenvolvimento integral da criança, visto que, o processo de desenvolvimento humano não se configura de maneira natural e ou espontânea, mas à guisa de muito conhecimento, planejamento e ação, ou seja, o ato educativo é diretivo e demanda intencionalidade por intermédio da organização e proposição de experiências de aprendizagem e de desenvolvimento humano. Nesta senda, nos valemos da BNCC para afirmar que, "[...] parte do trabalho do educador é refletir, selecionar, organizar, planejar, mediar e monitorar o conjunto das 
práticas e interações, garantindo a pluralidade de situações que promovam o desenvolvimento pleno das crianças" (BRASIL, 2017, p. 37).

Diante dos campos de experiências da Educação Infantil, onde se encontra a relação com a promoção da autonomia? Encontramos uma resposta viável a esta indagação, principalmente ao nos debruçarmos sobre os campos $O$ eu, o outro e o nós e o campo Corpo, gestos e movimento. O primeiro campo de experiência citado, sinaliza para o fato de que na medida que a criança passa a se identificar como ser individual e social, simultaneamente ela passa a participar "[...] de relações sociais e de cuidados pessoais, as crianças constroem a sua autonomia e senso de auto-cuidado, de reciprocidade e de interdependência com o meio" (BRASIL, 2017, p. 38), enquanto que o segundo campo de experiência citado, aponta para o fato que a criança apreende e depreende o mundo por intermédio do seu corpo e das múltiplas linguagens que se utiliza como forma de expressão. Neste contexto, em se tratando de autonomia, é possível destacar que, “[...] na Educação Infantil, o corpo das crianças ganha centralidade, pois ele é o partícipe privilegiado das práticas pedagógicas de cuidado físico, orientadas para a emancipação e a liberdade, não para a submissão". (BRASIL, 2017, p. 39).

Todavia, após a realização do movimento de análise dos campos de experiências e dos objetivos de aprendizagem e desenvolvimento para a Educação Infantil, dentro das faixas etárias dos bebês (zero a 1 ano e 6 meses), das crianças bem pequenas (1 ano e 7 meses a 3 anos e 11 meses) e das crianças pequenas (4 anos a 5 anos e 11 meses), um fator nos chama atenção, visto que, embora a descrição na BNCC do que consiste cada campo, faça a menção direta ou indiretamente a autonomia, ao avaliarmos os direitos de aprendizagem, essa discussão é praticamente ausente na faixa etária dos bebês e das crianças bem pequenas, sendo apresentada de maneira mais efetiva, com as crianças pequenas e no campo de experiência Corpo, gestos e movimento, entretanto, enfatizando as ações de higiene, de cuidado pessoal e de alimentação.

Esta análise, reporta para uma questão muito preocupante, visto que as crianças, independentemente de sua faixa etária, mas levando em consideração as experiências sociais de desenvolvimento humano que estabelecem, conseguem desenvolver pequenas ações, que compreendem desde aprender a tirar e colocar uma chupeta na boca, a segurar a mamadeira, a segurar um copo ou xícara no lugar da mamadeira, até mesmo 


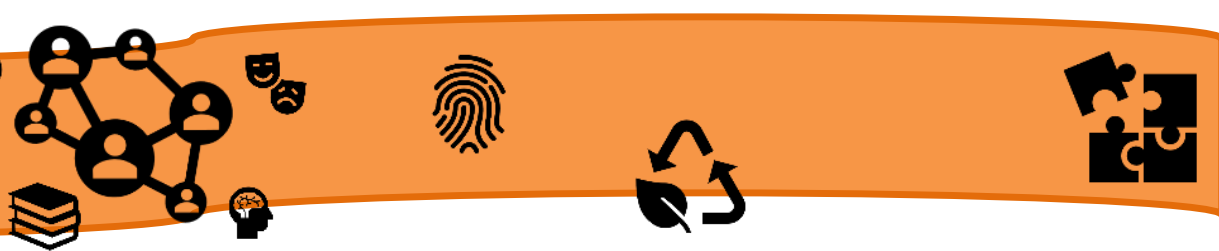

em ações mais complexas que envolvem a seleção do que irão comer, a dosagem das quantidades, o manuseio adequado do alimento e dos utensílios ao se servirem e por conseguinte se alimentarem sozinhas.

Se conseguimos visualizar o desenvolvimento da autonomia em questões que envolvem o autocuidado e a alimentação, como é possível não observarmos nos espaços em são possibilitados às crianças as oportunidades de realizarem as suas escolhas, nos momentos em que elas selecionam um livro para ser contado, numa música que apreciam para ser cantada e interpretada, numa brincadeira a ser realizada, na exploração de uma atividade, na resolução de um problema que abrange a turma? A BNCC da Educação Infantil posiciona a criança no centro do processo de ensino e de aprendizagem, mas a implicação deste posicionamento central precisa perpassar pelo processo de desenvolvimento, construção e apropriação da autonomia da criança em todas as faixas etárias.

Frente às problematizações desencadeadas, partimos então para o aprofundamento da discussão dos princípios da autonomia, que a partir de agora, serão ampliadas com vistas às contribuições de Paulo Freire, procurando estabelecer diálogos entre o autor e este princípio tão caro à infância.

Freire, ao longo de sua obra, assinala recorrentemente que a educação precisa se constituir como espaço de promoção da problematização, possibilitando dessa forma aos sujeitos, o desvelamento da realidade ao qual estão inseridos, por meio da realização da leitura de mundo. A proposta educativa de uma pedagogia problematizadora e libertadora dos sujeitos coloca-se como força de resistência e esperança que luta contra uma concepção bancária de educação, a qual ainda é, uma realidade presente em muitas escolas no mundo, e que infelizmente o Brasil não foge a essa regra. Nesse sentido, Freire (2017), propõe romper com a concepção de educação bancária vigente que é promotora de ações em que ocorrem,

[...] o ato de depositar, de transferir, de transmitir valores e conhecimentos, não se verifica nem pode verificar-se esta superação. Pelo contrário, refletindo a sociedade opressora, sendo dimensão da "cultura do silêncio", a "educação" "bancária" mantém e estimula a contradição. (FREIRE, 2017, p. 82).

A denúncia realizada por Freire (2017), acerca de uma educação bancária, nos possibilita a reflexão de como ela se materializa no cotidiano da Educação Infantil, onde 


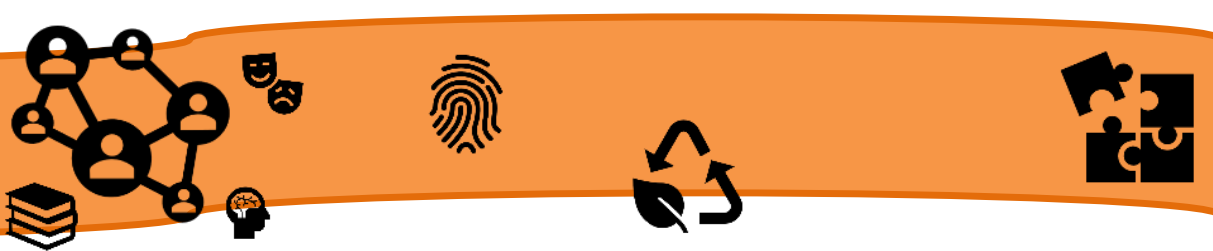

é possível traçarmos este cenário. Nela o educador assume o protagonismo do processo de ensino e de aprendizagem, ele é o sujeito que: educa, sabe, pensa, diz a palavra, disciplina, opta e prescreve sua opção, atua, escolhe o conteúdo programático, nega a liberdade e impõe aos educandos a condição de meros objetos do processo, que são vistos como seres da adaptação, do ajustamento, da acomodação, que são exercitados para armazenarem os depósitos de conteúdos que são realizados.

$\mathrm{Na}$ concepção bancária, as crianças da Educação Infantil tornam-se alvo do adestramento de seus corpos e de suas mentes, sendo-lhes inculcadas a docilidade, a mansidão, a subserviência, a obediência, a disciplina, o silenciamento e a imobilidade dos seus corpos sendo assim, “[...] tanto menos desenvolverão em si a consciência de que resultaria a sua inserção no mundo, como transformadores dele. Como sujeitos [...]" (FREIRE, 2017, p. 83). São negadas as necessidades das crianças de se movimentarem, de brincarem, de se expressarem, de dialogarem, de relatarem as suas considerações sobre aquilo que acontece em seu entorno que lhes provoca alegria, satisfação, segurança, conquista, descoberta ou medo, aflição, tristeza, ansiedade, desesperança, insegurança e incertezas.

Voltamo-nos, portanto, à atuação das educadoras na perspectiva de uma educação bancária, que imobiliza e enclausura as crianças em nome do apregoamento de um ensino propedêutico para o Ensino Fundamental que muitas vezes restringe a vivência plena da infância ao conhecimento do mundo das letras e dos números, descolando assim, o processo de ensino e de aprendizagem dos contextos sociais e culturais aos quais as crianças encontram-se encharcadas pelas experiências que fazem parte de seu cotidiano, impedindo-as de realizarem as suas leituras de mundo com a proposição de práticas pedagógicas, muitas vezes ditadas pelo próprio sistema de ensino, que desconsidera as especificidades e necessidades peculiares desta etapa de desenvolvimento humano.

O objetivo do processo educativo, em inúmeros centros de Educação Infantil, encontra-se restrito à preparação das crianças para o Ensino Fundamental, onde a brincadeira e as interações sociais são sucumbidas pela oferta do ensino de números e cálculos, de letras, famílias silábicas e palavras em atividades desprovidas de sentido e de significado. Sendo assim, por meio da oferta da educação numa perspectiva bancária, os educandos estarão em constante processo preparatório para atuarem numa sociedade 


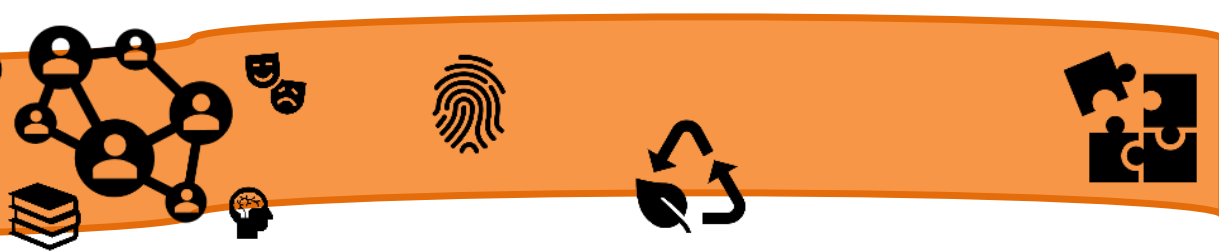

produtiva e consumidora, lançando no mercado produtos que se destacam pelo individualismo, pela polivalência, pela produtividade, pela pró-atividade, pela poliflexibilidade e pela competitividade, moldando-os aos altos padrões de exigência do mercado capitalista que é responsável pela apreensão da subjetividade dos educandos.

Freire (2006), destaca que a educação precisa promover a autonomia dos educandos, visto que, ela consiste num imperativo ético, num princípio educativo central e promotor da participação social, entretanto temendo a forma como a lógica mercadológica, pudesse vir a se apropriar deste princípio, vindo a distorcê-lo em torno de seus interesses próprios, ele constrói a seguinte crítica, “[...] é nesse sentido que reinsisto em que formar é muito mais do que puramente treinar o educando no desempenho de destrezas [...]. Daí a crítica permanentemente presente em mim à malvadeza neoliberal, ao cinismo de sua ideologia fatalista e a sua recusa inflexível ao sonho e à utopia" (FREIRE, 2006, p. 14).

Neste sentido, percebemos que a autonomia não se limita ao desenvolvimento e a aquisição de destrezas para se tornar um sujeito competitivo e que assume a dianteira no jogo da sobrevivência instituído por essa sociedade capitalista e mercadológica. Ao direcionarmos a discussão para os espaços formais educativos, ancoradas em Freire, compreendemos que a autonomia da criança não comporta o desenvolvimento de habilidades cognitivas e sociais utilizada para acelerar a aprendizagem e o desenvolvimento da criança, pois corre o sério risco de deixar de impregnar de sentido a cultura que pelo educador é mediada.

Mas, que autonomia Freire nos convida a discutir então? Ao delimitar, numa das poucas abordagens que realiza de maneira direta, o que é a autonomia, Freire (2006), assinala que ela consiste num processo de construção que é próprio de cada sujeito e se consolida, mediante as relações sociais tecidas com outros sujeitos em espaços e tempos históricos e culturais, partindo da premissa que os sujeitos são históricos e que produzem e são produzidos pela cultura.

Sendo assim, Freire (2006) afirma que,

a autonomia, enquanto amadurecimento do ser para si é processo, é vir a ser. Não ocorre em data marcada. É neste sentido que uma pedagogia da autonomia tem de estar centrada em experiências estimuladoras da decisão e da responsabilidade, vale dizer, em experiências respeitosas da liberdade. (FREIRE, 2006, p. 107). 


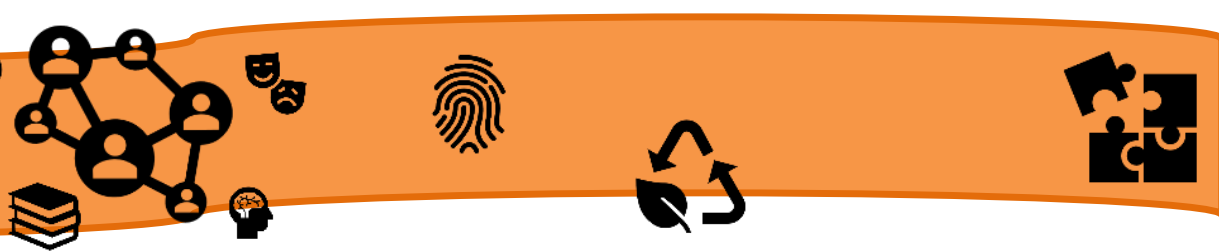

Desta forma, ao vivenciar experiências que estimulem as crianças a decidirem e a assumirem a responsabilidade sobre as decisões, elas começam a experienciar a liberdade que começa a subsidiar as decisões que tomam por si próprias. Portanto, compete aos educadores em situações formais de aprendizagem vivenciadas na escola ou aos familiares, no convívio do lar, promoverem situações onde seja possível ao sujeito construir a sua subjetividade autônoma.

A autonomia se constrói em todas as circunstâncias vivenciadas. Não há ações que podem ser classificadas em mais ou menos importantes, pois esse é um critério singular atribuído pelos sujeitos, mas não há como negar que as grandes decisões se alicerçam em todas as experiências, até mesmo nas mais simples, pois nesse processo tudo importa, tudo conta, não há experiências mais ou menos importantes. Segundo as ideias apresentadas pelo autor,

[...] o que é preciso, fundamentalmente mesmo, é que o filho assuma eticamente, responsavelmente, sua decisão, fundante de sua autonomia. Ninguém é autônomo primeiro para depois decidir. A autonomia vai se constituindo na experiência de várias, inúmeras decisões, que vão sendo tomadas. Por que, por exemplo, não desafiar o filho, ainda criança, no sentido de participar da escolha da melhor hora para fazer seus deveres escolares? Porque o melhor tempo para esta tarefa é sempre o dos pais? Por que perder a oportunidade de ir sublinhando aos filhos o dever e o direito que eles têm, como gente, de ir forjando sua própria autonomia? Ninguém é sujeito da autonomia de ninguém. Por outro lado, ninguém amadurece de repente, aos 25 anos. A gente vai amadurecendo todo dia, ou não. (FREIRE, 2006, p. 107).

Freire nos instiga a reflexão quando assinala na ideia acima supracita que o desenvolvimento da autonomia por parte da criança, possui relação direta com o desenvolvimento da responsabilidade sobre a decisão que ela tomou. Ao direcionarmos o nosso olhar para o espaço de aprendizagem da sala de aula, para uma situação que envolve a brincadeira, percebemos como esta ideia se materializa, pois ao manifestar o desejo de brincar com o brinquedo trazido pelo seu colega, a criança precisa compreender que necessariamente uma troca terá que acontecer, na medida em o seu colega cede e empresta o seu brinquedo, este mesmo movimento também será esperado dela, ou seja, ao pegar emprestado necessariamente terá que emprestar, ocorrendo assim a partilha, a interação, a cedência temporária de objetos aos quais os envolvidos na situação, possuem intenção ligação afetiva e subjetiva.

$\mathrm{Na}$ Educação Infantil geralmente os espaços e tempos destinados à brincadeira, além de consistirem em situações vitais de aprendizagem e de desenvolvimento humano, são permeados de conflitos e disputas, onde em diversas situações, as crianças 
não possuem a autonomia para resolver estes problemas e muitas vezes apelam para o choro, para atitudes agressivas, para a tomada abrupta do objeto de disputa ou com apelos diretos para que os educadores as auxiliem.

Frente ao exposto, faz-se necessária a mediação direta do educador durante estes momentos de conflito, que precisa intervir por meio da problematização e do diálogo até que juntos, possam encontrar a decisão mais justa que buscará fortalecer a criança no amadurecimento para si, no desenvolvimento da autonomia para resolver estas situações. Ao optarem por partilhar o objeto de desejo, neste caso, o brinquedo, terão o bônus de vivenciarem momentos de prazer, de alegria e de aprendizagem, caso não consigam chegar num acordo em comum e não aceitem fazer a troca, terão um ônus que implicará na frustração do não compartilhamento de interação com o objeto do colega, evidenciando assim, a necessidade de assumir a responsabilidade que acompanha a decisão por elas tomada.

Todavia, o educador poderia escolher o caminho menos complexo para resolver este tipo de conflito que acompanha os momentos de brincadeira, ele poderia decidir por conta própria que ninguém emprestaria e cada um iria brincar com o seu objeto trazido de casa, ele poderia tomar os brinquedos das crianças e justificar que como não sabem dividir, então ninguém mais ia brincar, poderia ainda colocar a criança que não queria emprestar o brinquedo sentada "pensando" sobre a sua ação "egoísta", poderia ignorar e ou minimizar o conflito instituído e assim propor uma outra atividade e poderia simplesmente abolir o dia do brinquedo trazido de casa na turma da Educação Infantil para evitar conflitos dessa ordem. Embora sejam soluções rápidas, que parecem eficazes para resolver os problemas e que infelizmente são adotadas por diversos educadores, ao analisarmos o impacto educativo delas nas crianças, é possível afirmar que são altamente negativos, pois negam o direito de aprenderem a decidir com autonomia e responsabilidade, negam a oportunidade de desenvolver a socialização, a cooperação, a reciprocidade, a empatia e a partilha, negam o direito de aprender e fomentam acima de tudo, a heteronomia dos educandos.

Aprofundamos as discussões sobre a prática educativa dos educadores, assinalando que as intervenções realizadas para e com as crianças, precisam respeitar a curiosidade, a inquietude, os gostos, os interesses, as necessidades, o movimento, o contexto histórico e cultural, a linguagem, as múltiplas formas de comunicação e de 
expressão dos educandos, sem desrespeitar as diferenças existentes entre os pontos de vista e concepções do educador e de seu educando, pois respeitar as singularidades de cada sujeito e a autonomia deles, não é uma benesse, mas sim uma discussão necessária de ser promovida, ela é um princípio ético necessário ao exercício da docência. Neste sentido, Freire (2006) contribui ao salientar que,

[...] outro saber necessário à prática educativa, e que se funda na mesma raiz que acabo de discutir - a da inconclusão do ser que se sabe inconcluso -, é o que fala do respeito devido à autonomia do ser educando. Do educando criança, jovem ou adulto. [...] O respeito à autonomia e à dignidade de cada um é um imperativo ético e não um favor que podemos ou não conceder uns aos outros. (FREIRE, 2006, p. 59, grifos do autor).

Freire (2006), adverte aos educadores que eles tem o dever ${ }^{12}$, de respeitar o educando em sua dignidade, que devem respeitar o processo de construção da identidade e da autonomia dos sujeitos, portanto, alerta que a prática educativa precisa atender essa demanda e não acentuar ainda mais os processos de desigualdade e exclusão social. Salienta ainda, que o papel de atuação do educador, na transição da heteronomia para a autonomia é árduo, tendo em vista que,

[...] se trabalho com crianças, devo estar atento à difícil passagem ou caminhada da heteronomia para a autonomia, atento à responsabilidade de minha presença que tanto pode ser auxiliadora como pode virar perturbadora da busca inquieta dos educandos; se trabalho com jovens ou adultos, não menos atento devo estar com relação a que o meu trabalho possa significar como estímulo ou não à ruptura necessária com algo defeituosamente assentado e à espera de superação. (FREIRE, 2006, p. 70, grifos do autor).

Neste viés, o autor afirma ainda, que os educadores precisam praticar a autoridade coerentemente democrática, Freire (2006), que compreende, o não silenciamento de quem sempre foi silenciado, a disciplina construída em relações respeitosas e não pela estagnação dos corpos e das mentes, mas, construída no alvoroço, na inquietude, na indagação, no diálogo, na esperança. Dessa forma, a autonomia vai se construindo enquanto processo que preenche o espaço que até então era ocupado pela

\footnotetext{
12 Expressão cunhada pelo autor no livro "Pedagogia da Autonomia: saberes necessários à prática educativa" (2006).
} 


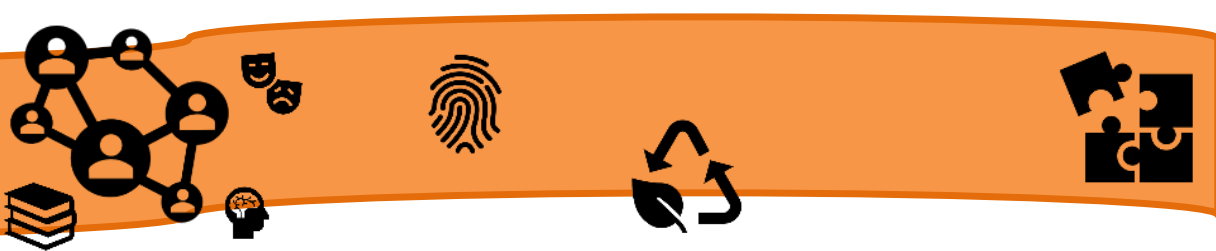

dependência. A autonomia se constrói por meio das responsabilidades que são assumidas pelos sujeitos.

Há que se ter equilíbrio para que a autoridade não assuma dimensões de autoritarismo onde praticamente nada é possível de decidir, de fazer, bem como a liberdade vivenciada pelos educandos, não se transforme em permissividade, em licenciosidade, onde não há regras e ilimitadamente tudo é possível, pois o desequilíbrio de ambos pode ser extremamente nocivo as crianças produzindo sujeitos aprisionados pelo medo ou por suas vontades.

Quanto a prática educativa, Freire (2006) pontua que os educadores precisam se ater ao difícil processo de transição da heteronomia para a autonomia, visto que é um trabalho árduo, pois a presença do educador tanto pode auxiliar, como pode dificultar esse processo de construção e busca inquieta da criança, de acordo com a prática educativa que assumir em sala de aula, poderá vivenciar a tensão existencial entre a autoridade e a liberdade. Por fim, assinala que os educadores precisam "[...] transcender sua tarefa meramente instrutiva e assumir a postura ética de um educador que acredita verdadeiramente na autonomia total, liberdade e desenvolvimento daqueles que ele ou ela educa”. (FREIRE, 2014, p. 116).

\section{RESULTADOS ALCANÇADOS}

Este estudo realizado, sinalizou que os apontamentos relativos ao princípio da autonomia abordados por meio de documentos nacionais $(1998 ; 2009 ; 2017)$ e da bibliografia na obra de Freire $(2017 ; 2014 ; 2011 ; 2006)$ consultada, evidenciaram que os documentos nacionais específicos à Educação Infantil, embora contemplem a discussão sobre a autonomia, abordam superficialmente essa temática, conferindo linhas gerais quanto a construção de uma proposta educativa promotora da autonomia enquanto princípio que deve ser respeitado pela proposta curricular da Educação Infantil, mas as discussões enfatizam as relações de cuidados pessoais, auto-organização e saúde, DCNEI (2009).

Com relação aos RCNEI (1998), as diretrizes contidas nesta proposta curricular voltadas à infância, sinalizam um avanço histórico para a discussão da temática da autonomia, pois dentre um enunciado de temas, realiza especificamente esta discussão, 
resultando num avanço significativo no que tange principalmente a disposição dos objetos e materiais ao alcance e necessidades das crianças.

Quanto a discussão da autonomia num sentido mais amplo, os RCNEI (1998) e as DCNEI (2009) estabelecem diálogos que alargam as ideias para a promoção de espaços de decisão, de autogoverno no cotidiano da Educação Infantil, chamando-nos a atenção que embora as diretrizes, importem muitas abordagens dos referenciais, este aspecto, no que tange a promoção de espaços de decisão, de posicionamento e de organização das atividades que realizam, não foi contemplado neste documento.

No documento da BNCC (2017), a autonomia é categorizada como uma competência a ser apropriada no percurso da Educação Básica. Neste documento encontramos importantes contribuições para a Educação Infantil, no que tange o desenvolvimento integral da criança, apresentando os direitos de aprendizagem, os campos de experiências e os objetivos de aprendizagem, todavia, ao buscarmos depreender as proposições para a construção da autonomia, percebemos que embora a proposição deste documento curricular coloque a criança no centro do processo educativo, este conceito praticamente se perde, sendo abordado de maneira tênue e quando abordado, os objetivos e experiências de aprendizagem e desenvolvimento humano se voltam para as crianças pequenas, compreendendo o atendimento da faixa etária de 4 anos a 5 anos e 11 meses.

Em contrapartida, Paulo Freire $(2017 ; 2014 ; 2011 ; 2006)$, autor de uma pedagogia revolucionária e libertadora, que recebe até os dias atuais, rótulos que o predestinam essencialmente à Educação de Jovens e Adultos (EJA) e aos Movimentos Sociais, o precursor e autor da Pedagogia Freireana, oferece importantes contribuições que possibilitam a discussão dos princípios da autonomia na Educação Infantil, enquanto imperativo ético, enquanto amadurecimento do ser para si nas relações sociais e culturais constituídas por sujeitos históricos, na qual a atuação do educador, na proposição de uma concepção de educação problematizadora e libertadora, numa perspectiva democrática e emancipadora dos sujeitos, possibilita às crianças, decidirem, opinarem, se posicionarem e agirem, interferindo de maneira transformadora no mundo.

Ao sintetizar os principais aspectos abordados nesse estudo, é possível perceber que Freire, embora não tendo uma produção específica destina para a infância, tem muito a contribuir com esta etapa da Educação Básica, principalmente na ampliação do 


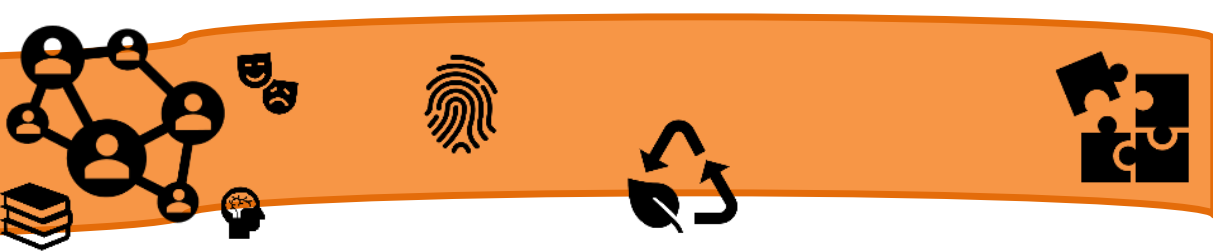

tema da autonomia que muitas vezes é subestimado pela literatura específica da Educação Infantil, tendo em vista que o autor promove a discussão com vistas a promoção da práxis educativa comprometida com o desenvolvimento da criança autônoma, ou seja, na formação de subjetividades livres, participativas, democráticas e solidárias, pautadas pela criticidade a qual origina a leitura do mundo, o respeito a diversidade e a luta pela equidade.

Oxalá consigamos, encontrar outros espaços, outros educadores no Brasil e no mundo dispostos a promoverem diálogos que se contrapõe a uma educação bancária, educadores e educadoras dispostos a promoverem diálogos carregados de amorosidade, de fé, de esperança, de consciência crítica entre Freire e as infâncias.

\section{REFERÊNCIAS}

BRASIL. Parecer CEB n. 22/98. Resolução CEB n.1, 7 de abril de 2009. Diretrizes curriculares nacionais para a educação infantil. Brasília, DF: CNE/CEB, 2009.

BRASIL. Ministério de Educação e do Desporto. Referencial curricular nacional para educação infantil. Brasília, DF: MEC, 1998. (v. 2).

BRASIL. Ministério da Educação e do Desporto. Base nacional comum curricular. Brasília, DF: MEC, SEB, 2017.

CAMPOS, Maria Malta; ROSEMBERG, Fúlvia. Critérios para um atendimento em creches que respeite os direitos fundamentais das crianças. Brasília, DF: MEC, SEB, 2009.

FREIRE, Paulo. Pedagogia do oprimido. Rio de Janeiro/São Paulo: Paz \& Terra, 2017.

FREIRE, Paulo. Pedagogia dos sonhos possíveis. Rio de Janeiro: Paz \& Terra, 2014.

FREIRE, Paulo. Educação como prática da liberdade. Rio de Janeiro: Paz \& Terra, 2011.

FREIRE, Paulo. Pedagogia da autonomia: saberes necessários à prática educativa. São Paulo: Paz \& Terra, 2006. 


\title{
CONCEPÇÕES DE LEITURA EM UM LIVRO DIDÁTICO DE LÍNGUA PORTUGUESA: UMA PROPOSTA DE ANÁLISE
}

\author{
SILVA, Gracielle Angeline Tavares da ${ }^{13}$ \\ BERNARDINO, Maria Lucivania da Silva ${ }^{14}$
}

\section{RESUMO:}

Este trabalho destina-se a uma análise conceitual, diagnóstica e avaliativa, referente ao modo como a concepção de leitura no ensino em língua portuguesa é abordada nos anos finais do ensino fundamental. Para isto, adotaremos como objeto de estudo um livro didático do $9^{\circ}$ (nono) ano, intitulado "Língua Portuguesa", da coleção Universos, aprovado pelo Programa Nacional do Livro Didático 2017 (PNLD), a partir do qual procuraremos investigar as atividades desenvolvidas em relação ao módulo selecionado, tendo por base as definições preconizadas pelos Parâmetros Curriculares Nacionais PCN (BRASIL, 1998), Francelino (2010), Silva (2011), bem como de outros autores consagrados na literatura. A pesquisa revelou que o livro apresentou um conteúdo significativo voltado para a compreensão leitora, à qual é dado um tratamento sistemático quanto à sua proposta pedagógica (organização interna, eixos temáticos e articulação com as demais modalidades da língua - escrita, oralidade, reflexão e análise linguística) por meio de exercícios contextualizados, exigindo dos docentes uma postura mais crítica e reflexiva no que tange ao processo ensino-aprendizagem e ao papel desempenhado pelos discentes, buscando torná-los sujeitos ativos, capazes de processar textos com eficiência nas diversas situações comunicativas interacionais.

PALAVRAS-CHAVE: Concepção de leitura. Ensino Fundamental. Livro didático.

\section{INTRODUÇÃO}

Os Parâmetros Curriculares Nacionais (BRASIL, 1998) recomendam como metodologia de ensino atividades que envolvam o uso da língua, como produção e compreensão de textos orais e escritos, sob a perspectiva de gêneros discursivos/textuais, entremeado de reflexão sobre a língua e a linguagem, objetivando as possibilidades de uso. Portanto, segundo os PCNs (BRASIL, 1998), o ensino da língua deve ter como propósito a produção/recepção de discurso, permitindo ao professor fazer uma análise do que poderá discorrer com os alunos diante do grau de

\footnotetext{
${ }^{13}$ Doutora em Produtos Naturais e Sintéticos Bioativos (UFPB). Atualmente é concluinte do Curso de Licenciatura em Letras Língua Portuguesa pela Universidade Federal da Paraíba (UFPB). E-mail: graccietavares@gmail.com

${ }^{14}$ Graduada em Ciências Contábeis pela Universidade Federal da Paraíba (UFPB). Graduada em Letras Língua Portuguesa pela Universidade Federal da Paraíba (UFPB). Atualmente exerce a função de contadora na PB. E-mail: lucivania-y@hotmail.com
} 


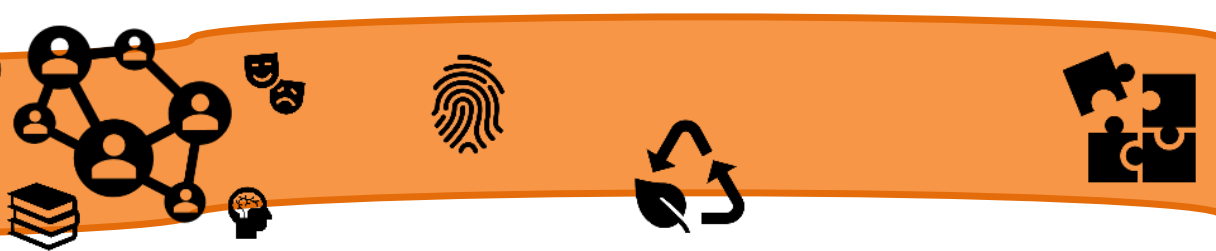

conhecimento ou dificuldades que apresentam.

A leitura é uma competência linguística de importância primordial, pois através dela é possível alcançar um objetivo básico, o de formar cidadãos críticos na sociedade em que se vive. A escola é a instituição detentora do papel de cativar no aluno o gosto e a satisfação pela leitura, oferecendo, assim, situações a fim de que ela se desenvolva de forma qualitativa. Com a mediação do professor e do livro didático, os estudantes têm a oportunidade de conhecer e analisar diferentes textos, e através de atuações intermediadas, passam a inter-relacionar-se com o outro e produzir conhecimento, estando aptos para expressar tanto na escrita quanto verbalmente suas ideias, experiências próprias e conhecimento geral de mundo (ALVES, 2012).

O leitor precisa considerar a escola como o lugar que promove essa busca inicial pela leitura, com o intuito do desenvolvimento do saber. Partindo de tal premissa, temos aí um espaço socializador do conhecimento, com a incumbência de propiciar aos alunos o aprendizado da leitura, possibilitando-lhes também o acesso a uma grande variedade de textos com conteúdo significativos, favorecendo a formação de leitores competentes e autônomos (GONÇALVES, 2012).

Deste modo, é de extrema importância a seleção de bons textos para leitura ou escuta, pois, possibilita ao aluno aperfeiçoar-se cada vez mais acerca do uso da linguagem, desempenhando, ainda, habilidade na produção de textos e na análise e reflexão linguística (MARTINS, 2010; 2011).

No que concerne à prática de leitura é importante destacar que um mesmo gênero poderá ser apresentado para sujeitos em séries distintas, porém, com um grau de exigência diferenciado, pois, determinados temas demandam um conhecimento de mundo, que podem não estar presentes em alunos nas séries iniciais. Desse modo, contempla-se a prática da leitura como um meio de descoberta e de atribuição de sentidos, viabilizando essa interação tão necessária entre leitor-mundo (BRASIL, 2016).

\section{OBJETIVOS}

Os objetivos que nortearam este trabalho visaram avaliar as práticas de leitura em um livro didático de Língua Portuguesa, aplicado ao Ensino Fundamental II, observando-se sua legitimidade conceitual, seu papel reflexivo e crítico frente à 


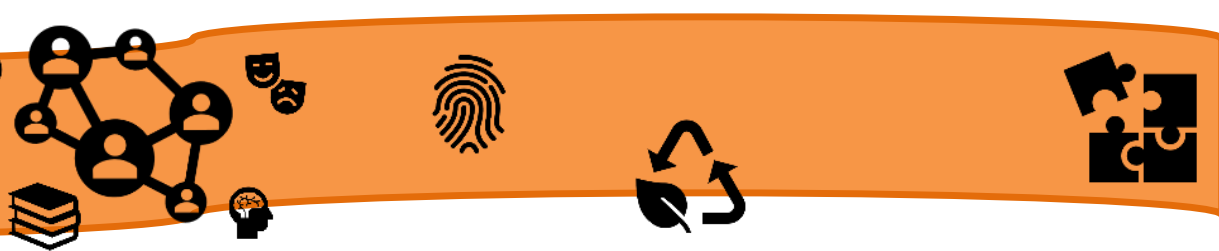

formação de leitores competentes via texto-autor-leitor, sugerindo novos questionamentos e ideias para os conteúdos sugeridos.

\section{METODOLOGIA}

A abordagem metodológica da pesquisa fundamentou-se no exame qualitativo descritivo-analítico, do tipo documental, tendo como corpus de análise o volume 9 do livro didático "Língua Portuguesa", da coleção Universos, destinada a alunos do nono ano do Ensino Fundamental, de Pereira (2015).

Os critérios adotados para a triagem do material didático pautaram-se, inicialmente, na escolha do nível de ensino, delimitando-se o fundamental II, entre o sexto e o nono ano, optando-se por elencar este último, por acreditarmos que os conhecimentos nos anos finais do ensino fundamental estarem mais consolidados pelos aprendentes, além de ser um período de transição para o Ensino Médio, exigindo, hipoteticamente, maior aprofundamento teórico, prático, reflexivo pelo material didático. Este, por sua vez, teve sua eleição efetuada consoante sua aprovação ou não pelo Programa Nacional do Livro Didático 2017, instigando-nos a selecionar uma obra validada pelo PNLD por, teoricamente, atender à proposta trazida pelos PCN. Deste modo, buscaremos comprovar ou refutar sua adequabilidade frente a este raciocínio.

O livro didático adotado está organizado em quatro unidades temáticas específicas, possuindo caráter variado quanto aos conteúdos trabalhados, estando subdivididas em três capítulos, dispostos em cinco seções, a saber: Antes da leitura, Durante a leitura, Texto, Depois da leitura e Oficina de textos. Ao final de cada unidade existe uma seção especial denominada "Projetos", a qual propõe o desenvolvimento e aperfeiçoamento de atividades relativas ao assunto da unidade.

Em seguida, dentre o universo dos diferentes módulos de ensino da Língua Portuguesa - leitura, oralidade, escrita, análise e reflexão linguística, adotou-se a modalidade leitura como parâmetro prospectivo de competência linguística, ou seja, a capacidade de agir eficazmente em um tipo de situação específica, a partir da mobilização de recursos cognitivos diversos (saberes, capacidades, informações, reflexão, análise, hipótese, comparação, relação, inferência, dentre outros) sem, contudo, limitar-se a eles, mas, pelo contrário, utilizá-los no desenvolvimento e resolução de questões cotidianas. 


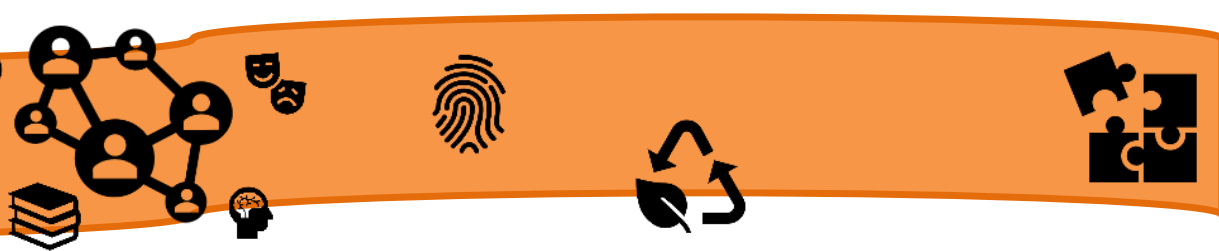

De acordo com Francelino (2010), a competência possibilitaria ao aprendente o desenvolvimento de sua capacidade linguística de compreensão e produção dos textos orais e escritos, adequando-se aos mais variados cenários sociocomunicativos, posicionando-se criticamente frente ao conteúdo que recebe, lê ou ouve (sujeito ativo), formulando hipóteses e respostas significativas para intervir como leitor, como coparticipante proficiente de sua língua materna de origem.

\section{FUNDAMENTAÇÃO TEÓRICA}

Durante muito tempo a leitura esteve associada à visão restrita de um processo educativo pautado essencialmente na alfabetização dos indivíduos. Em virtude disso, tornou-se um objeto histórico imprescindível ao desenvolvimento da aprendizagem e ensino em Língua Portuguesa. O eixo leitura engloba competências diversas, desde o domínio alfabético decodificativo de escrita até a compreensão e interpretação de textos multimodais, além da identificação dos gêneros discursivos, sendo uma prática que exige motivação contínua. Conforme reitera Martins (1994, p. 30) “[...] o ato de ler se refere tanto a algo escrito quanto a outros tipos de expressão do fazer humano, caracterizando-se também como acontecimento histórico e estabelecendo uma relação igualmente histórica entre leitor e o que é lido".

Assim, a leitura é, sobretudo, um ato social que transcende a simples decodificação da linguagem escrita, exigindo a participação ativa do leitor no processo de significação e construção do texto, a partir de seu conhecimento linguístico, textual e prévio de mundo adquirido ao longo da vida (KLEIMAN, 2011), proporcionando a aquisição constante de conhecimentos e contribuindo para a formação de um pensamento crítico, principalmente no ensino fundamental, nível de educação formal no qual surgem as primeiras dificuldades de compreensão leitora.

O ensino da Língua Portuguesa na educação fundamental $\left(6^{\circ}\right.$ ao $9^{\circ}$ ano) demanda ações educativas que contemplem não apenas o ambiente escolar dos sujeitos, mas também e, sobretudo, os diversos letramentos pertencentes ao universo cultural, social e econômico dos discentes, imprescindíveis às reflexões teórico-pedagógicas no ensino da língua e ao diálogo com a variedade dos gêneros discursivos emergentes do cotidiano dos indivíduos. 


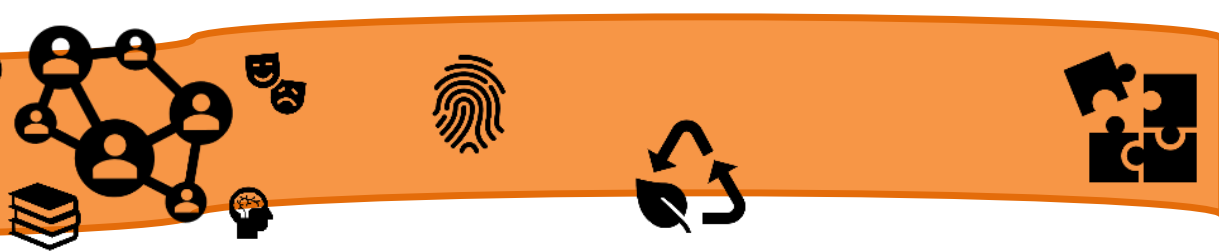

Entretanto, o que se observa na realidade, é uma distonia entre teoria e prática. É frequente nos livros didáticos a leitura de textos previamente formulados para a resolução de questões interpretativas, sem finalidade pré-definida e com pouca relação com o contexto de vida dos alunos, levando a uma leitura limitada, artificial e mecânica, não despertando nestes o interesse por aquilo que está sendo lido (GERALDI, 2003).

Nesse sentido, vários trabalhos vêm sendo desenvolvidos no intuito de analisar a forma pela qual o ensino da leitura no ensino fundamental (I e II) é estruturado, buscando apontar possíveis falhas e sugerir novos rumos à criação de uma prática leitora proficiente, apresentando aos discentes a leitura como algo prazeroso e essencial ao seu crescimento social e educacional. O professor desempenha um importante papel como mediador na formação de leitores, devendo "proporcionar atividades inovadoras, procurando conhecer os gostos de seus alunos e a partir daí escolher um livro ou uma história que vá ao encontro das necessidades da criança, adaptando o seu vocabulário, despertando esse educando para o gosto, deixando-o se expressar" (SOUZA, 2004, p. 223).

\section{ANÁLISE DO LIVRO DIDÁTICO (RESULTADOS E DISCUSSÕES)}

Após uma análise geral do livro selecionado para a concepção teórica desta pesquisa - competência leitora - foi possível constatar a predominância do tratamento reflexivo sobre a língua na série Universos, aprovada pelo PNLD 2017.

Embasada na visão de leitura preconizada pelos Parâmetros Curriculares Nacionais de Língua Portuguesa (BRASIL, 1998), segundo os quais a leitura “[...] é o processo no qual o leitor realiza um trabalho ativo de compreensão e interpretação do texto, a partir de seus objetivos, de seu conhecimento sobre o assunto, sobre o autor, de tudo o que sabe sobre a linguagem, etc.”, a coleção traz uma proposta que extrapola a definição de leitura enquanto processo meramente decodificativo (no qual ao leitor caberia a habilidade de identificação e reconhecimento dos sinais gráficos do texto, extraindo-lhe o sentido meramente linguístico, passando, assim, o aprendente, a atuar como um sujeito passivo da atividade pedagógica e, a leitura a ser reduzida a um exercício de caráter mecânico), indo além, engajando-se numa perspectiva cognitivista e, sobretudo, discursiva e sociointeracionista, cuja produção de sentidos se dá essencialmente na relação dialógica, construtivamente ativa, entre o sujeito e o texto. 


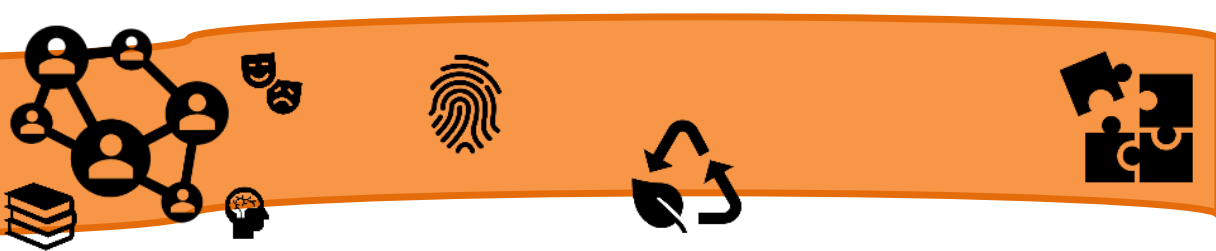

A leitura torna-se, assim, um mecanismo dinâmico, contextualizado e praticado por sujeitos sociais, históricos e produtores de sentidos. O sentido do texto só passa a ter sentido quando o sujeito atua e interage com o material escrito. Desta forma, as atividades do livro em questão demonstraram-se eficientes no estabelecimento do elo que perfaz texto-autor-leitor (o aluno).

A teoria descrita no parágrafo anterior pode ser reforçada pelas estratégias de leitura contidas no livro, didaticamente sequenciadas em três etapas: antes da leitura (predominando o foco no leitor, na sua percepção cognitiva individual do tema trazido em cada texto, sob o viés psicolinguístico), durante a leitura (também voltada para o leitor, desta vez com a proposta da leitura compartilhada, na qual o objetivo de leitura é definido, bem como as instruções para sua execução, suscitando a elaboração de hipóteses pelos alunos através do contexto, a partir de sua interação com o texto proposto, predominando, portanto, o enfoque interacionista) e, por fim, a etapa depois da leitura (contemplando a concepção sociocultural, em que os alunos na condição de sujeitos ativos são convidados a reconstruírem os sentidos do texto, por meio da ativação de conhecimentos extralinguísticos, focando o texto como prática social construída na relação autor-texto-leitor-contexto, despertando neles o senso crítico de leitura).

Segundo as definições preconizadas pelos PCN as relações de ensinoaprendizagem deverão efetuar-se a partir da tríade que envolve aluno-objeto de conhecimento-professor. Essa lógica visa à transformação dos alunos em cidadãos autônomos e participativos, sendo, portanto, imprescindível ao professor uma reflexão pedagógica sobre as práticas de ensino. O professor adquire a função de mediador do conhecimento, deixando de lado o papel de figura autoritária, detentor do saber, concepção esta consagrada por séculos, passando a introduzir o aluno no processo de construção do conhecimento. O discente adquire, assim, a posição de sujeito ativo, capaz de agir socialmente, ser reflexivo e responsável pelo seu aprendizado (SILVA, 2011).

É na prática reflexiva sobre a língua e a linguagem que se desenvolve a competência discursiva dos sujeitos nas diversas situações comunicativas de interação social e histórica. Uma vez que a finalidade do ensino linguístico se articula no processo de produção/recepção dos discursos, a prática pedagógica não poderá jamais ser 


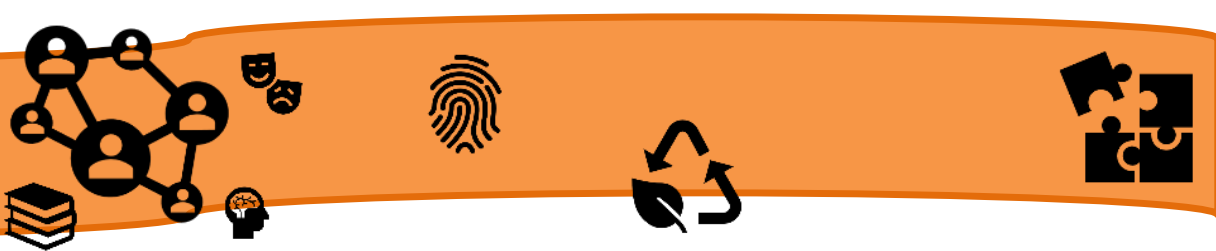

fragmentada, descontextualizada e dissociada do emprego efetivo e reflexivo da língua (eixos articuladores), os quais perfazem sua totalidade de sentido, seus aspectos sociais e discursivos (SILVA, 2011).

Os PCNs apontam um movimento metodológico que garanta o ensino da língua portuguesa através de técnicas, englobando seu uso (escuta/leitura de textos, produção/compreensão textual oral e escrita) em diferentes gêneros textuais (discursivos), seguidas de atividades de reflexão sobre a língua e a linguagem (análise linguística), aprimorando suas possibilidades de realização.

Desta forma, a série da coleção Universos estrutura seu procedimento técnico de ensino por intermédio da indução, da reflexão, da observação, da análise, da investigação dos aspectos linguísticos, ao invés de expor conceituações préestabelecidas, procurando tornar o aluno um leitor competente, estimulado a conhecer as situações de uso da língua portuguesa e os tratamentos linguísticos dados frente aos diferentes contextos. Como consequência, o discente encontra um universo de ensino mais produtivo ao desenvolvimento da habilidade leitora.

Outro ponto interessante notado no nosso corpus de estudo é o trabalho da leitura através dos gêneros textuais/discursivos, articulados com o uso da língua, possibilitando o aperfeiçoamento da capacidade sociocomunicativa dos aprendentes. Sob esse aspecto, a definição contida nos PCN revela que o discurso pode ser definido como uma espécie de prática comunicativa que se realiza numa determinada situação, abrangendo tanto o conjunto de enunciados que lhe deu origem quanto as condições nas quais foi produzida. Quando concretizado manifesta-se linguisticamente por meio de textos.

O texto, por sua vez, compreende o produto da atividade discursiva oral e escrita que forma uma unidade significativa global, independente de sua extensão. É uma sequência verbal constituída por um conjunto de relações estabelecidas a partir da coesão e coerência (a textualidade). Só é texto quando tais requisitos estão nele presentes, caso contrário não passaria de um amontoado aleatório de enunciados, sem sentido.

Todo texto se organiza dentro de um gênero específico. Os gêneros, por sua vez, são formas relativamente estáveis de enunciados, determinados historicamente e 


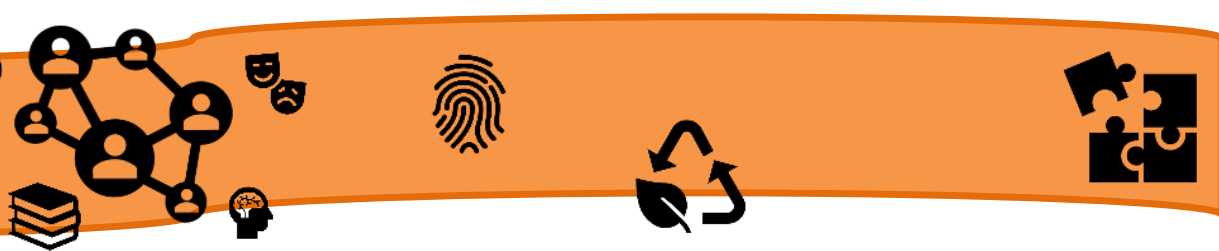

disponíveis na cultura, caracterizando-se por três elementos: conteúdo temático, estilo e construção composicional.

Em relação ao módulo "leitura", o livro didático analisado apresenta ampla heterogeneidade de gêneros, autores, contextos sociais e culturais de uso, textos de natureza multimodal, reiterando seu caráter experimental significativo. Ademais é baseado na visão interacionista, figurando além das estratégias cognitivas convencionais requeridas numa atividade de leitura decodificativa.

Conforme descrito no item "Metodologia" deste artigo, o volume nove da coletânea Universos (Língua Portuguesa) apresenta-se organizado em quatro unidades, dispostas em três capítulos. As unidades compreendem: "Eu (não) saio do padrão", "O movimento do olhar", "E vai rolar a festa!" e "Fazendo escola". É possível observar ainda, ao final de algumas unidades, a presença de uma seção intitulada "Atividades Integradas" e, outra, denominada "Projetos", destinadas ambas ao aperfeiçoamento de questões interdisciplinares integradas aos conteúdos, temas, gêneros desenvolvidos em cada unidade, nesse caso, voltados para as diferentes estratégias de leitura.

Os capítulos são compostos de seções e subseções, estruturadas de modo a privilegiar a competência leitora em detrimento das demais modalidades da língua, de modo a tornar o aluno um leitor proficiente em Língua Portuguesa, articulado com os demais eixos linguísticos do conhecimento (análise e reflexão linguística, produção textual oral e escrita).

As seções e subseções de leitura incluem as seguintes atividades: "Antes da leitura", "Durante a leitura", "Depois da leitura" ("A reconstrução dos sentidos do texto" e "A gramática na reconstrução dos sentidos do texto").

Os PCNs elencam, para a efetiva sequenciação dos conteúdos de língua portuguesa, alguns critérios fundamentais, articulados em torno de três fatores: a necessidade do aluno, sua possibilidade de aprendizagem e o grau de complexidade do objeto e das exigências das tarefas. Seguindo tais fundamentos, percebemos que existe na disposição categórica do livro estudado uma pertinência na sequenciação dos conteúdos ao nível de ensino proposto (nono ano), estando os mesmos adequados aos anos finais do ensino fundamental (II).

Os doze capítulos elencados na obra ("Todo mundo odeia falsas promessas", "A poesia na boca do povo", "Um exercício de cidadania”, "Um olhar para a eternidade", 


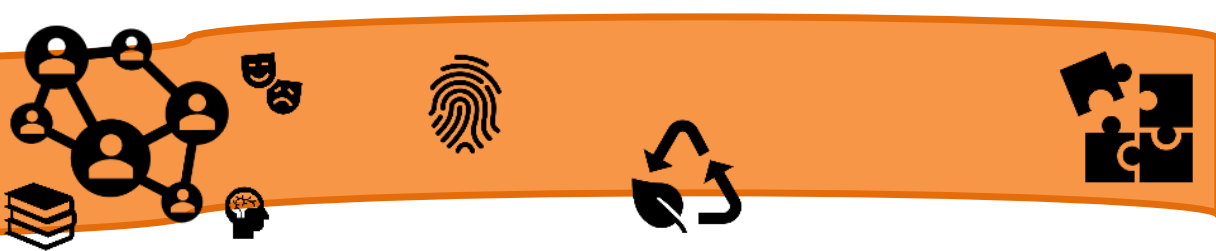

“O vernáculo sob espreita", "Universo ao meu redor", "Valeu, boi!", "Para dizer até breve”, "Tem raça de toda fé", "Senta que lá vem a história!", "E agora, José?” e "A opinião que vem da aldeia") abrangem gêneros como o discurso político-estudantil, a canção, o manifesto, a crônica, o poema, a reportagem, o discurso de formatura, o texto enciclopédico, o conto, a reportagem e o artigo de opinião, arranjados de maneira gradativa no que tange à sua complexidade, respeitando a capacidade cognitiva e intelectual do aluno, promovendo uma melhor compreensão dos assuntos mostrados e introduzindo os aprendentes aos autores, músicos, artistas consagrados (Paul Grice, João Gilberto, Antônio Carlos Jobim, Caetano Veloso, Chico Buarque, Renato Russo, Tarsila do Amaral, Oswald de Andrade, Lobão, Tom Zé, Rita Lee, Goya, Clarice Lispector, Carlos Drummond de Andrade, João Guimarães Rosa, Charles Baudelaire, dentre outros) e temas representativos do cenário literário brasileiro e da literatura estrangeira (Segunda Guerra Mundial, Bossa Nova, Jovem Guarda, Tropicalismo, Antropofagia modernista, movimento punk, rock dos anos 80, tribalismo, mitologia, infância, amor, fidelidade, o sentimento de solidão em meio à multidão, relações entre indivíduo e sociedade, cultura popular, amizade, relações afetivas, Educação de Jovens e Adultos, festas religiosas, religião africana etc).

Conforme pudemos ver na descrição do parágrafo precedente, no livro didático em questão há compromisso na busca de um ensino transversal. A transversalidade da LP pode ser empreendida a partir do entendimento de que a língua é dinâmica e funciona como um instrumento de expressão, representação e transformação apropriados pelos sujeitos para possíveis intervenções em seu meio social, cultural e histórico. Os temas transversais, por assim dizer, possibilitam ao sujeito discernir, refletir e expressar-se autenticamente sobre questões efetivas, pautando-se sobre diversos pontos de vista (concepção de valores) e suas diferentes formas de enunciação argumentativas, bem como apreender os domínios lexicais a partir da articulação com as diversas áreas temáticas envolvidas. Portanto, a integração de questões sociais no ensino da língua portuguesa possibilita ao professor o desenvolvimento de um trabalho amplo, inserido em realidades temáticas distintas e voltado, sobretudo, para a produção intelectual do aluno.

\section{CONSIDERAÇÕES FINAIS}


GONÇALVES, Ana Cecília Teixeira; PINTON, Francieli Matzenbacher. O ensino da produção textual em diferentes perspectivas teóricas. XII Seminário Internacional em Letras. Língua e Literatura na (pós-) modernidade, 2012.

KLEIMAN, Ângela. Texto e Leitor: aspectos cognitivos da leitura. 14. ed. São Paulo: Pontes, 2011.

MARTINS, Maria Helena. O que é leitura. 19. ed. São Paulo: Brasiliense, 1994.

MARTINS, Iara F. de Melo; SILVA, Camilo Rosa. A gramática na sala de aula: análise e reflexão linguística. In Regina Celi Mendes Pereira (org.) Ações de linguagem: da formação continuada à sala de aula. João Pessoa: EDUFPB, 2010. p. 148-170.

MARTINS, Iara F. de Melo. Análise linguística na formação continuada: discussão sobre mecanismos relacionais. In Regina Celi Mendes Pereira (org.) Entre teorias e práticas: o que e como ensinar nas aulas de português. João Pessoa: EDUFPB, 2011. p. $167-184$

PEREIRA, Camila Sequetto. Universos: língua portuguesa, $9^{\circ}$ ano: anos finais: ensino fundamental. São Paulo: Edições SM, 2015.

SILVA, Camilo Rosa. Crenças e concepções sobre gramática: os discursos desvelando as práticas. In Regina Celi Mendes Pereira (org.) Entre teorias e práticas: o que e como ensinar nas aulas de português. João Pessoa: EDUFPB, 2011. p. 185-203.

SOUZA, Renata Junqueira de. Leitura do professor, leitura do aluno: processos de formação continuada. UNESP - Presidente Prudente. 2004. 



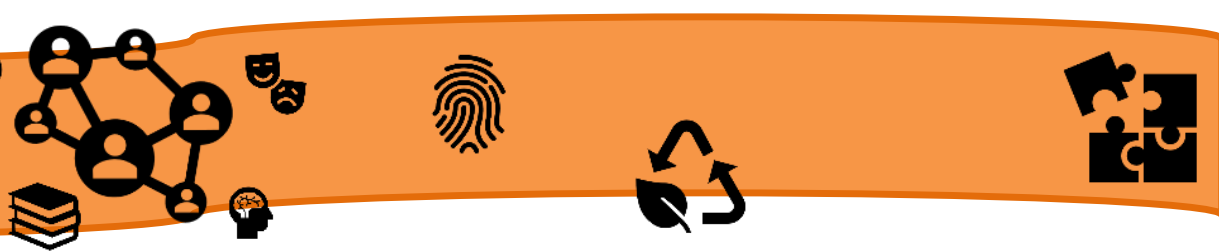

Este trabalho tem como objetivos proporcionar a partir da dança, a integração das crianças, dando-lhes oportunidades de expressar sensações, sentimentos e emoções, ampliando assim, seus repertórios de movimentos e aquisição de conhecimento da linguagem oral e escrita.

Sabemos que a criança nasce, se desenvolve e cresce, conhecendo o mundo e vivenciando experiências através do seu próprio corpo. Este é um dos meios de ação que ela utiliza para explorar e interagir no espaço em que vive. Em todas as fases do seu desenvolvimento observa-se a importância do corpo como uma forma de expressar suas emoções. Nanni (1995) confirma essa prática ao explicar que o movimento corporal é de vital importância para o desenvolvimento da criança pois pelas suas habilidades motoras ela expandi seus conhecimentos.

Assim, a Dança, em seu caráter educativo informativo, pode oferecer o despertar para a construção da disciplina e responsabilidade, através de esforços de autocontrole e de comportamentos socialmente aceitáveis. Aliado a isso, de forma orientada e corresponde a maturidade de cada fase. As atividades com dança proporcionam o desenvolvimento de atividades lúdicas, simbólicas e criativas, e segundo Papalia e Olds (2000), são de extrema relevância para o desenvolvimento total da criança.

A dança aliada ao brincar imaginário sócio-político tem como fim o aprimoramento biopsicossocial da criança. Portanto, cabem às escolas a conscientização e a valorização por parte dos profissionais quanto à realização de trabalhos pedagógicos voltados para a Arte, incluindo a Dança no currículo, como componente importante para o desenvolvimento das crianças na fase pré-escolar.

Em 1996, com a nova lei de diretrizes e bases da educação nacional (BRASIL, 1996), foi instituído o ensino obrigatório de Artes no território nacional e finalmente em 1997 foram publicados os Parâmetros Curriculares Nacionais (PCN) que inclui, pela primeira vez na história do país, a Dança como componente curricular.

É preciso que estejamos em consonância com a perspectiva da diversidade e da multiplicidade de propostas e ações que caracterizam o mundo contemporâneo, sendo necessário lançarmos um olhar mais crítico sobre a dança na escola com final a transmissão do conhecimento hoje, como sabemos, não se restringe mais aos quatro saberes da escola que são definidos como: aprender a conhecer, aprender a fazer, aprender a viver com os outros, aprender a ser. 


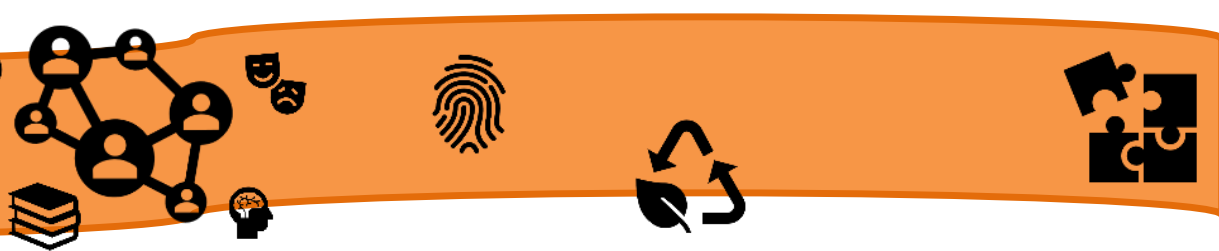

Ao contrário, muitas vezes nossas escolas estão correndo atrás de migalhas para favorecer ao aluno oportunidades diversas de conhecimento, que por sinal é necessário estarmos atentos ao fato de que a escola deve dialogar com a sociedade em transformação, pois ela é o lugar privilegiado para que o ensino de Dança se processe com qualidade, compromisso e responsabilidade por si, mas acima de tudo, pode garantir continuidade, aprofundamento e relação com outras áreas do currículo.

O desenvolvimento desta proposta de trabalho surgiu diante de observações feitas em que percebíamos alguns alunos mostrando em sala de aula a coreografia de determinadas músicas do seu cotidiano, surgindo assim uma inquietação: será que podemos desenvolver um trabalho pedagógico nesta turma como estímulo à expressão?

Verderi (2000, p. 54) Declara que: “a dança na escola deve proporcionar oportunidades para que o aluno desenvolva todos os seus domínios do comportamento humano e por meio de diversificações e complexidades o professor contribua para a formação de estruturas corporais mais complexas". Em consonância com este pensamento a dança deve e precisa existir em nossos currículos escolares, dando ênfase a criatividade e a expressividade corporal das crianças por sinal.

Essa proposta objetiva a busca de uma prática pedagógica mais coerente com a finalidade escolar em que os alunos possam expressar-se através de movimentos espontâneos e coordenados de acordo com sua possibilidade individual e cultural.

Desenvolvemos o trabalho com a clareza de que a dança na escola não pode ser tida como a arte do espetáculo, mas como a educação por meio da arte. Essa percepção foi de suma importância para o desenvolvimento do aspecto físico, afetivo e social dos alunos envolvidos. Nesta perspectiva, compreendemos que a dança permite ao indivíduo não só uma busca de sua personalidade, mas ensina-o a viver em sociedade, a se relacionar com o seu eu e com próximo, de forma prazerosa e não como uma obrigação. Segundo Freinet (1990, p. 49):

A criança tem necessidade de andar e saltar dois pontos não a podemos condenar a ficar em imóvel, porque certamente falharíamos e a prejudicaríamos (...) porque a criança tem necessidade de agir, Criar e trabalhar, Isto é, empregar a sua atividade numa tarefa individual ou socialmente útil.

Diante do que o autor disse, dançar é tão importante para criança quanto falar, cantar ou aprender geografia. É essencial para a criança que nasce "dançando", não 


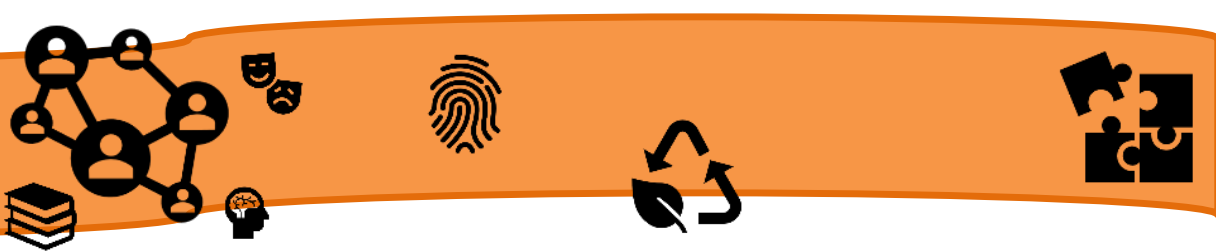

desaprender essa linguagem pela influência de uma educação repressiva e frustrante. Por isso, a educação deve unificar corpo e mente, ensinando a pensar em termos de movimento para dominá-los, e não apenas se preocupar com o domínio da escrita, do raciocínio lógico abstrato e da linguagem.

Enfim, considerando que a dança deve estimular na criança a criatividade na conquista da sua autonomia as experiências com o corpo dançante, devem fazer parte da prática pedagógica. É importante reafirmar que combinar interesses e desafios corporais no ambiente integrativo entre a criança, emoções, pessoas e o mundo da dança, é referencial para o aprendizado.

O trabalho teve como metodologia o desenvolvimento de uma sequência didática onde utilizamos música, dança, videoclipes, coreografia criada pelos alunos e relatos dos trabalhos através de desenhos.

A sequência didática se desenvolveu através de atividades desenvolvidas com música, movimentos corporais apresentados pelos alunos de antes da Melodia ouvida, que a partir desse ponto foi possível criar estratégias de ensino, englobando o videoclipe das músicas trabalhadas e criar atividades de leitura e escrita para o registro escrito do que foi feito.

O texto está organizado da seguinte forma: desenvolvimento, em que apresentamos o detalhamento das atividades desenvolvidas, os materiais utilizados, os objetos e a avaliação; e as considerações finais, que são as contribuições do projeto, bem como pontos negativos e positivos.

\section{DESENVOLVIMENTO}

Iniciamos o projeto fazendo um levantamento dos conhecimentos prévios dos alunos com questões como:

Você gosta de música? quais?

Quando você dança, o que sente?

Fizemos várias questões aos alunos e tudo foi registrado. Diante do que foi exposto fizemos a seguinte pergunta: Será que nós poderíamos desenvolver em sala de aula atividades com músicas e dança? 


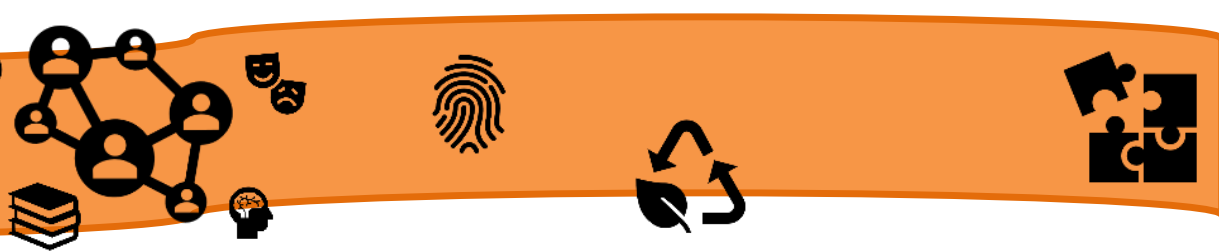

As respostas foram muito positivas, alguns alunos disseram que queriam dançar "Ai Se Eu Te Pego" (Michel Teló), entre outras, mas pedimos que eles tivessem calma que iríamos organizar um cronograma com danças de vários ritmos.

A partir dos conhecimentos prévios dos alunos e vemos uma conversa relativa à compreensão deles diante do assunto e fizemos um paralelo entre as danças que eles costumavam ver e dançar, com as e juntos iriamos trabalhar em sala de aula.

Diante de uma conversa informal, apresentamos a proposta de trabalho para realização do nosso projeto e explicamos que todas as atividades desenvolvidas iriam fazer parte de um trabalho final do curso de pós-graduação em Educação Infantil. Observamos que todos ficaram contentes e cheios de expectativas.

Convidamos os alunos a irem a sala de vídeo para assistir a um DVD com danças infantis (Xuxa Só Para Baixinhos 1 e 2), onde no qual eles dançaram livremente. Alguns dançavam com mais expressividade, apresentando movimentos aeróbicos, e outros mais tímidos ficavam só mexendo o corpo de um lado para o outro sem tirar os pés do lugar, outros pulavam sem parar, alguns que ficaram só observando

No final, voltamos para a sala de aula e observamos sobre o que tínhamos realizado na sala de vídeo, distribuímos papel e lápis de cor para que cada aluno desenhasse a dança que eles mais gostaram. Foram reproduzidos vários desenhos sobre o tema acima citado, observamos que as cenas que mais chamaram a atenção foram as danças juninas apresentadas no DVD. Apesar do nosso projeto ter como foco a movimentação corporal através de dança, achamos importante desenvolver a leitura e escrita, possibilitando aos alunos expressarem também suas emoções e sentimentos obtidos durante a dança, colocando-os no papel.

Para Verderi (2000) a Dança na escola é um meio de estimular os movimentos corporais, possibilitando que aprender cantando e dançando, estimulando o corpo e o cérebro com atividades prazerosas e promovendo o bem-estar da criança. Laban (1978) ressalta a importância da expressão corporal, como ponte para a socialização, em que podemos perceber progressos de inclusão de alguns alunos inibidos e que sempre rejeitavam participar de atividades coletivas.

Organizamos alguns materiais como: aparelho de som, CDs, papéis, lápis de cor, giz de cera e vídeo de máquina fotográfica para registro de imagens. Utilizamos várias músicas para a realização do projeto como: cabeça, ombro, joelho e pé (Xuxa), 
desengonçada (Bia Bedran); Pintinho Amarelinho (Gugu); alfabeto da Xuxa (Xuxa) e indiozinho (Eliana).

Todas as músicas trabalhadas foram dançadas livremente com espontaneidade, mas algumas crianças criaram sua própria coreografia. Diante disso, mostramos para elas os benefícios o que a dança representa em nossas vidas. No final, colocamos a música cabeça, ombro, joelho e pé (Xuxa), para trabalharmos movimentos corporais, como: coordenação motora, espaço, equilíbrio, as partes do corpo, concentração e deixamos eles à vontade na forma de dançar. As atividades de movimento despertam a criatividade da criança diante a letra da música.

É muito importante que durante a aula aconteçam movimentos e questionamentos, pois as crianças sentem a necessidade do movimento e da ação. Para Freinet (1990) é preciso que haja em sala de aula oportunidades em que a criança possa se entregar à atividade, seja individualmente ou em grupo. Um dos focos principais que aparecem durante a realização do projeto foi que a dança estimulou a socialização das crianças e também o prazer de estar no ambiente escolar, onde tinham a possibilidade de criar movimentos diferentes, sempre na forma de brincadeira ou numa construção interação com colegas.

Dando sequência na sala de aula, fomos assistir um dvd produzido por nós professoras a partir de vários vídeos baixados do You Tube, apresentando vários tipos de danças do nosso país como: funk, hip hop, axé, carnavalescas, forró, arrocha, pop, sertaneja e rap. Realizamos uma conversa informal diante do que tínhamos assistido e pedimos que eles falassem da dança que mais lhe chamou atenção. Foi possível observar que a cena que mais chamou a atenção das crianças foi a do carnaval. Diante disso, sugerimos uma atividade para casa, em que eles juntamente com os pais iriam criar sua própria fantasia.

No dia posterior, os alunos apresentaram suas fantasias e por meio de uma roda de conversa, demos a oportunidade de eles relatarem sobre a fantasia, estimulando-os pelas seguintes perguntas: quem fez? Onde compraram? Qual o tema? Foi usada pela primeira vez? Tiveram alguns alunos que não trouxeram fantasia, mesmo assim participaram da aula, interagindo com os demais alunos e a aula terminou numa grande festa fantasia. 


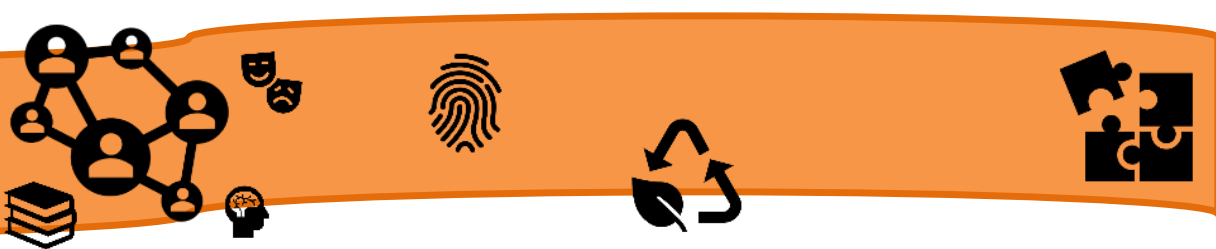

A utilização dos videoclipes: cabeça, ombro, joelho e pé (Xuxa), Desengonçada (Bia Bedran); Indiozinho (Eliana) tiveram como principal ponto, despertar a visão das crianças diante da música que elas já conheciam, despertando um novo olhar, ou seja, a mesma música pode ser dançada de diversas formas. Como esperávamos, eles não conseguiram ficar só assistindo, deste modo, interagiram com o que iam vendo no vídeo, tentando fazer os mesmos movimentos corporais apresentados na projeção.

Ao término da projeção, fomos para sala de aula, onde desenvolvemos questionamentos sobre o que foi assistido: semelhanças e diferença do videoclipe das músicas e a maneira como a qual eles dançaram em sala de aula?

A participação das crianças foi bastante satisfatória, assim fizemos com as demais músicas, íamos questionando-os, respondendo e registrando no quadro as respostas das crianças.

Para Bertazzo (2004), o estímulo da coordenação motora nunca deveria cessar, assim como não deveria cessar a evolução intelectual. Quando se estimula e se aprofunda a experiência motora é uma importante ligação, surge entre as movimentações pessoais e o mundo.

Todas as atividades tiveram como objetivo a integração e socialização das crianças, diante o ensino-aprendizado, com avaliações contínuas, proporcionando nas crianças o prazer, favorecendo a autoestima e aprimoramento dos aspectos sociais e emocional, no meio escolar e também no ambiente na qual estavam inseridas, tornando real a possibilidade de criticar e movimentar-se no espaço.

\section{CONSIDERAÇÕES FINAIS}

A Dança não tem seu fascínio só como arte, mas também em sua ação pedagógica, podendo trazer grandes contribuições para o desenvolvimento infantil, principalmente na fase pré-escolar, em que as habilidades mais importantes estão sendo formadas.

Os resultados desta pesquisa foram gratificantes, pois foi possível observar que as crianças sentem prazer em movimentar o seu corpo e tocá-lo, e também as possibilita conhecer seus limites diante a dança, o espaço e as direções. As crianças percebem que há diferentes possibilidades de se mover ao som de uma música: podem estar agachadas, sentados e até mesmo deitado no chão. 


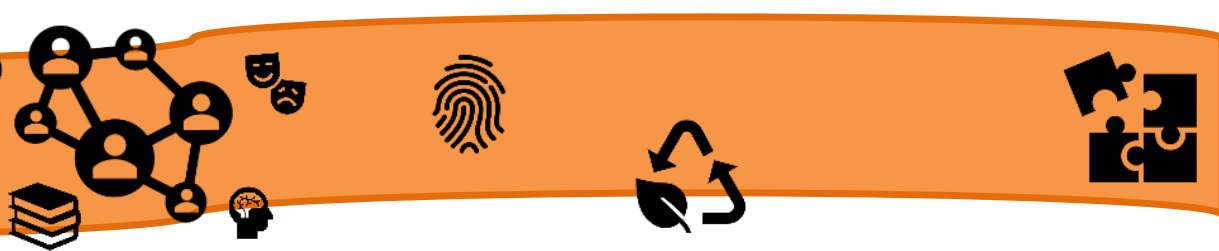

A realização desta experiência foi bastante gratificante, mesmo diante de algumas dificuldades em relação às mídias que estavam em falta em nossa escola e alguns equipamentos quebrados como o aparelho de dvd e o aparelho de som; mas isso não impediu a sua efetivação. Como pontos positivos, o crescimento dos alunos no âmbito social, emocional, físico, desenvolvimento do senso estético e cultural à medida que reforçam as ações e as transformações práticas que os movimentos corporais proporcionam ao aluno nessa fase de aquisição de conhecimento.

Uma das observações que devem ser destacadas neste projeto se refere aos fatores culturais das crianças dentro do meio em que se inserem, pois elas têm o contato com músicas em casa, que gostariam de desenvolver as coreografias, exemplo dessas músicas: músicas da banda Grafith (famosa banda no RN, atingindo das camadas mais populares às mais elitizadas).

Percebemos que a maioria desenvolvia movimentos com seu corpo em canções adultas, como a citada anteriormente. Foi muito importante o trabalho com movimentos corporais, mas é preciso que nossas escolas contribuam para que essa prática esteja cada vez mais presente nos currículos escolares, mas que infelizmente muitos dois profissionais se prendem a livros didáticos e paradidáticos, tornando o ambiente escolar visto pelas crianças como desconfortável e não prazeroso.

Assim, concluímos que a Dança pode e deve fazer parte do currículo escolar e iremos desenvolver sempre atividades envolvendo danças, movimentos e coreografias, pois somos conscientes de que a dança é uma maneira de expressar ideias e emoções. Isso não pode ficar de fora quando se quer formar crianças, que descubram o prazer do movimento, mesmo que nossas instituições não tenham materiais necessários para este tipo de trabalho, temos que buscar subsídios e objetos que favoreçam o desenvolvimento de projetos educacionais com responsabilidade e clareza e que enriqueçam o contexto cultural, social e emocional dos alunos.

\section{REFERÊECIAS:}

BERTAZZO, I. Espaço e corpo: guia de Reeducação do movimento. Editora SESC: São Paulo, 2004.

BRASIL. Lei De Diretrizes E Bases Da Educação Nacional. - 2. ed. - Brasília : Senado Federal, Coordenação de Edições Técnicas, 1996. 
Parâmetros Curriculares Nacionais / Ministério da Educação e do Desporto, Secretaria de Educação Fundamental. — Brasília: MEC/SEF, 1997.

FREINET, M.L.M N. Uma revolução na sala de aula. In textos básicos de educação pré-escolar. Editora Ática: São Paulo, 1990.

LABAN, R. Domínio do movimento. Editora Summus: São Paulo, 1978.

NANNI, Dionísia. Dança educação - Pré-escola à universidade. Editora Sprint: Rio de Janeiro, 1995.

PAPALIA, D. OLDS, S. (2000). Desenvolvimento Humano. (D. Bueno, trad.) Porto Alegre: Artmed (trabalho original publicado em 1998).

VERDERI, E.B. Dança na escola. $2^{\text {a }}$ edição. Editora Sprint: Rio de Janeiro, 2000. 
CPPS: DEMOCRATIZAÇÃO DE ACESSO AO IFFAR- CAMPUS SÃO BORJA

\author{
MACHADO, Alexander da Silva ${ }^{16}$ \\ KAEFER, Maria Teresinha Verle ${ }^{17}$
}

\title{
RESUMO:
}

O projeto de extensão do Instituto Federal Farroupilha - Campus São Borja, CPPS Curso Preparatório para o Processo Seletivo, tem como propósito oportunizar aos alunos concluintes do ensino fundamental, oriundos das escolas públicas da cidade, que almejam ingressar no IFFar- campus São Borja, um suporte nos estudos, contribuir para minimizar as diferenças com os estudantes que buscam cursos particulares e facilite $o$ acesso ao Instituto. Os alunos do ensino médio integrado e os das licenciaturas em física e matemática da Instituição são os próprios ministrantes. As vagas disponibilizadas para o CPPS são sessenta, as aulas acontecem aos sábados no turno da manhã. O Curso Preparatório evidencia a troca de conhecimentos nas diversas áreas que envolve o processo seletivo. Igualmente promove um ambiente de acolhida e de empatia entre os participantes e ministrantes. Além de viabilizar o conhecimento do futuro espaço escolar. O projeto proposto está em seu sétimo ano de execução (2018), com números considerados positivos no percentual de aprovação no Processo seletivo do IFFar campus São Borja, corroborando com os objetivos propostos. Na edição de 2017 - sexta edição, tivemos sessenta e cinco concluintes e, destes, quarenta e quatro foram aprovados na primeira e segunda chamada, totalizando $67 \%$ de aprovados.

PALAVRAS-CHAVE: Educação Popular. Acesso. Democratização

\section{INTRODUÇÃO: CONSTRUINDO SONHOS}

O Curso Preparatório para o Processo Seletivo - CPPS é um curso de extensão que teve o seu início em 2012, criado para auxiliar os alunos da rede pública da cidade de São Borja a ingressarem no IFFar. Encontra-se em seu sétimo ano e as aulas são ministradas no período que compreende em torno de onze sábados antecedentes ao dia do Processo Seletivo, garantindo assim acesso a todas e todos, pois não interfere nas atividades letivas regulares.

São realizadas atividades de raciocínio lógico e interpretação, que contemplam as disciplinas básicas do ensino fundamental, auxiliando na compreensão dos conhecimentos aprendidos. São oferecidas setenta vagas a alunos que estão finalizando

\footnotetext{
${ }^{16}$ Mestre em Integração Latino-Americana- UFSM. Professor do Instituto Federal Farroupilha - Campus São Borja, docente de História, E-mail: alexander.machado@iffarroupilha.edu.br.

${ }^{17}$ Mestre em Educação-UFRGS. Professor do Instituto Federal Farroupilha - Campus São Borja, Docente de Pedagogia, Líder do Grupo de Pesquisa Emancipação sem Fronteiras: Formação Inicial e Continuada de Professores-IFFar. E-mail: maria.kaefer@iffarroupilha.edu.br
} 
o nono ano do ensino fundamental. $\mathrm{O}$ curso cumpre uma importante função social ao atender alunos de escola pública, ao ajudar na divulgação do Instituto e na consolidação da identidade de uma jovem instituição, enquanto espaço de educação pública e de pertencimento as classes populares. O CPPS é ministrado unicamente por nossos alunos do ensino médio integrado e das licenciaturas em Física e Matemática, que atuam como monitores e são responsáveis por dar as aulas e fazer a acolhida. Aos professores da instituição compete o papel de orientar os monitores, além de acompanhar a elaboração, a organização e a execução das aulas.

\section{OBJETIVOS: O QUE QUEREMOS CONSTRUIR}

O projeto de extensão do Instituto Federal Farroupilha - Campus São Borja, Curso Preparatório para o Processo Seletivo, também conhecido como CPPS, tem por objetivo geral:

- Possibilitar aos alunos de escolas públicas da cidade, que desejam ingressar na Instituição, um apoio nos estudos, de forma que possam reduzir as diferenças com os estudantes que buscam cursos particulares e facilite o acesso ao Instituto, intervindo como instrumento para minimizar a ação dicotômica que o sistema de ensino apresenta.

Podemos elencar como objetivos específicos:

- Integrar a comunidade com a Instituição, divulgando os cursos que temos e propiciando

- que mais pessoas tenham acesso ao Instituto Federal Farroupilha que tem um ensino público, de qualidade;

- Promover o conhecimento através da troca de informações pelas diferentes áreas em que o Processo Seletivo abrange, além de oferecer um espaço interativo entre os ministrantes e participantes.

- Verticalizar o ensino, ao estimular os alunos de ensino médio a continuar os estudos no IFFar, podendo inclusive cursar as licenciaturas oferecidas no campus (matemática e física), como cursos de tecnologia e bacharelado de acordo com os eixos de verticalização;

- Propiciar que os alunos do ensino médio e das licenciaturas sejam os atores 


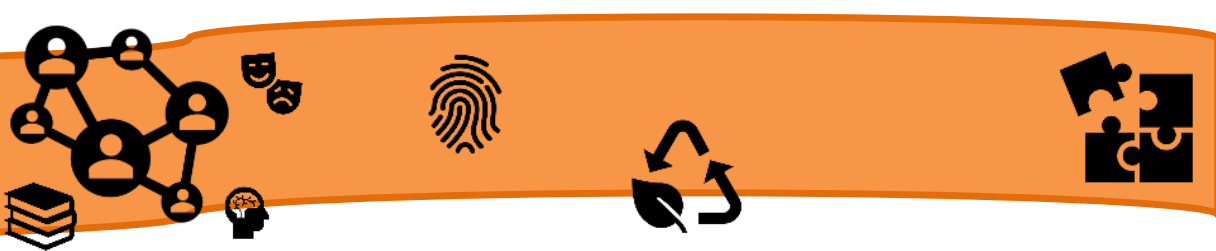

principais desse processo de ensino e aprendizagem, estimulando-os assim a perceberem as desigualdades sociais e educacionais da região e a compreenderem a atuação deles pode alterar um pouco essa realidade. Estimulando um sentimento de pertencimento dos sujeitos à esta Instituição Pública.

\title{
REFERENCIAL TEÓRICO: O CAMINHO PERCORRIDO DE MÃOS DADAS COM A EDUCAÇÃO POPULAR
}

Diante da complexa realidade do ensino público no país, da dualidade educacional, e da negação de oportunidades iguais, especialmente aos filhos dos trabalhadores, temos claro a importância do Curso Preparatório para o Processo Seletivo do IFFar - campus São Borja no ingresso das classes populares ao espaço de educação pública e de qualidade, espaço pensado para democratizar as oportunidades de acesso e permanência de todos os cidadãos. Cumprindo assim, seu papel de ser fonte de informação, empoderamento, reflexão e, na extensão desses preceitos, um espaço de aprendizado dos conhecimentos históricos, culturais e políticos. Nascimento (2002) nos aponta essas questões quando discute sobre os movimentos dos cursos pré-vestibulares populares:

\begin{abstract}
A democratização das relações sociais no Brasil é um processo historicamente relacionado à capacidade de luta e de organização da sociedade. Diante da diversidade de problemas e das questões que se apresentam como desafios para a construção de uma sociedade mais justa, e diante da negação de direitos e oportunidades para parcelas significativas da população brasileira (o que acontece desde a colonização e atinge preferencialmente alguns grupos sociais, como os negros e índios), organizaram-se e continuam organizando-se vários movimentos sociais (NASCIMENTO, 2002, p. 1).
\end{abstract}

O Curso de extensão proposto tem como finalidade incentivar e auxiliar os alunos das escolas públicas uma maior preparação de estudo ao Processo Seletivo para o ingresso nos cursos integrados do IFFar - campus São Borja, processo concorrido, inclusive por uma grande maioria de alunos advindos das escolas particulares. Esta ação de extensão nasceu para auxiliar no rompimento com posições pré-estabelecidas e desiguais para alunos das escolas públicas, que para Brandão: 


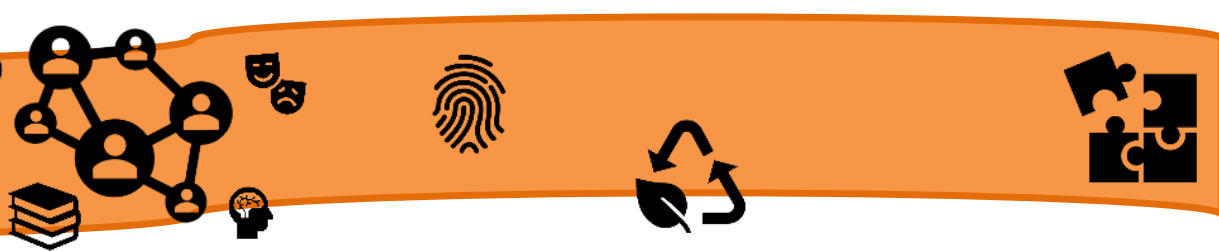

Um simples andar pela cidade revela aquilo que a fala oficial justifica: a educação do povo é deficiente e desvela aquilo que ela oculta: a deficiência aparentemente acidental sustenta a necessidade de que a educação seja desigual. Afirmando possuir as condições do jogo, onde todos de início são dados como iguais e partem das mesmas condições, sobre as quais a diferença da qualidade individual estabeleça a diversidade dos resultados, ela se realiza como um rito, onde as posições estão desmarcadas de modo antecedente e desigual, e os resultados, portanto, são conhecidos antes de serem cumpridos pelos atores da escola (BRANDÃO, 2006, p. 26).

$\mathrm{Na}$ intenção de romper essa lógica antecedente e desigual, que o CPPS oportuniza aulas extras, ministradas pelos estudantes do ensino médio integrado, com auxílio dos acadêmicos das licenciaturas oferecidas na instituição e orientação de docentes, atividades de raciocínio lógico, interpretação, compreensão entre outros conceitos presentes nas diferentes disciplinas estudadas durante o ensino fundamental. Vale lembrar que partimos do pressuposto teórico de Freire (1996, p. 47) de que "ensinar não é transmitir conhecimento, mas criar as possibilidades para a sua própria produção ou sua construção", por isso valorizar a dialogicidade no processo de ensino e aprendizagem é fundamental, sendo uma constante neste projeto.

Todo o curso é permeado pela intencionalidade do desvelamento da realidade local, acontecendo atividades que envolvem desde os conteúdos do ensino fundamental, passando por questões ligadas ao empoderamento dos sujeitos quanto ao seu lugar de fala e de ação, bem como de pertencimento da comunidade local a este espaço público de educação. Nesta perspectiva, trazemos para a pauta Paulo Freire (2005, p. 20), em Pedagogia do Oprimido, quando diz que : "Educador e educandos (liderança e massas), co-intencionados à realidade, se encontram numa tarefa em que ambos são sujeitos no ato, não só de desvelá-la e, assim, criticamente conhecê-la, mas também no de recriar este conhecimento".

Esperançoso de poder contribuir com as classes menos favorecidas, que o CPPS nasceu, tornando-se uma referência de equidade "[..] uma parcela da população que é colocada em situação de desvantagem pela situação de pobreza que lhe é imposta (NASCIMENTO, 2002, p. 1).

\section{METODOLOGIA: O CAMINHO ESCOLHIDO}




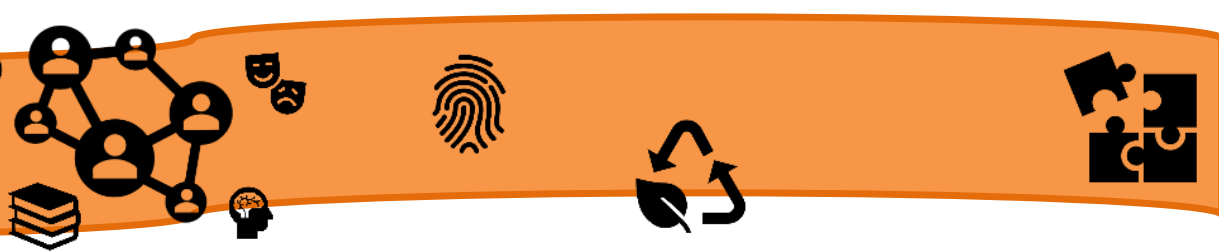

Nos primeiros anos, as aulas aconteciam pelo período da manhã e tarde, de sábados antecedentes à prova, em que cada aula era finalizado os conteúdos de uma disciplina, porém, buscando um melhor rendimento dos alunos e ministrantes, o projeto começou a ser realizado apenas aos sábados pela manhã para que os jovens pudessem ter a tarde livre para suas atividades.

Assim, as disciplinas de história, matemática, português e geografia são concluídas em dois sábados consecutivos e as disciplinas de física, química e biologia são ministradas em um sábado para cada uma delas. O curso propõe atividades dinâmicas, através do uso de recursos como vídeos, slides, debates, rodas de conversa, utilizando-se de estratégias para tornar mais atrativos estes momentos de retomada dos conhecimentos adquiridos.

No último sábado de aula os inscritos recebem um treinamento para o processo seletivo, um simulado, tal qual a prova que enfrentarão para acessar o campus São Borja. As atividades do simulado são feitas pelos docentes que contribuem no projeto como orientadores e a montagem da prova, no padrão do Processo Seletivo, é realizada pelos bolsistas, desde o processo de diagramação ao processo de impressão.

A última atividade realizada pelo CPPS é o aulão. Na véspera da aplicação da prova do processo seletivo, os monitores de todas as disciplinas ministram uma aula no campus, aberta a toda a comunidade, inclusive quem não está inscrito no curso, para tirar algumas dúvidas recorrentes dos alunos e para tentar dar as últimas dicas que ajudarão no dia da realização da prova.

As inscrições para o curso CPPS ocorriam, até o ano de 2016, na extensão do IFFar-SB, por ordem de chegada e preenchimento uma ficha. Em 2017 foram realizadas pelo sistema SIGAA, que é o Sistema Acadêmico da Instituição, sem deixar de oferecer as presenciais para os que não tem acesso à internet. Para o ano de 2018 será implementada a seleção por meio de sorteio público, pois entendemos que esta forma de seleção parte do mesmo pressuposto de equidade para todos, evitando que os que tenham mais acesso à informação ou as tecnologias tenham vantagem sobre os demais.

A divulgação começa aproximadamente com um mês de antecedência por redes sociais, visita às escolas e avisos nas rádios disponíveis na cidade. Além desses meios de divulgação, o projeto conta com uma página no Facebook na qual os alunos têm acesso às notícias, calendário das aulas, material para estudo, entre outros. 


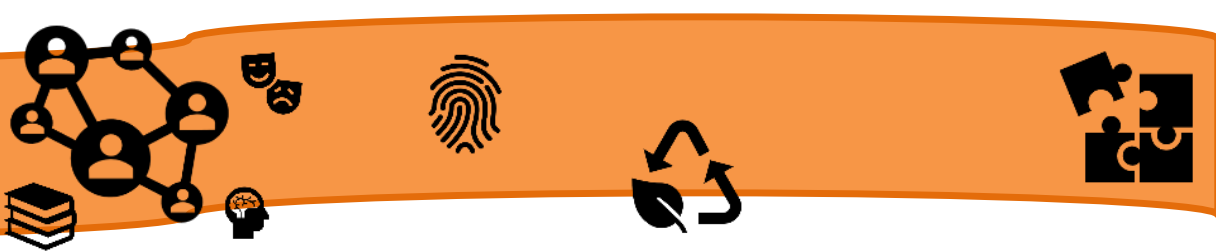

As aulas têm um período de aproximadamente três meses e meio. De 2012 a 2015 as aulas aconteciam em período integral do sábado. A partir de 2016 acontecem no turno da manhã dos sábados com 15 minutos de intervalo.

A distribuição das disciplinas e dos conteúdos a serem abordados segue a seguinte organização: a cada sábado é abordado uma matéria, Português, Matemática, História e Geografia tem dois finais de semana para ser trabalhados pela grande proporção de conteúdo e ciências engloba Biologia, Química e Física têm apenas um sábado, pois o processo seletivo química e física têm somente 2 questões e 4 de biologia.

\section{ANÁLISE E DISCUSSÃO: ALGUNS RESULTADOS NA CAMINHADA}

O projeto tem seis anos de execução dentro do campus São Borja e sempre obteve boas médias de aprovação no processo seletivo, tendo em vista que o objetivo estabelecido pela coordenação é de que mais de $50 \%$ dos participantes possam ser aprovados. Neste contexto, para termos uma ideia do alcance do projeto, no ano de 2017 foram aprovados $68 \%$ dos alunos, contando a primeira e a segunda chamada para ambos os cursos, Técnico em Eventos e Técnico em Informática. Outro resultado importante a ser mensurado é o envolvimento de ex-alunos do CPPS nos projetos do campus, pois passam a conhecer todas as possibilidades que a instituição proporciona, mas especialmente pelo empenho em se tornarem monitores para auxiliar na execução do projeto.

Existe ainda um diálogo importante dos dois cursos de licenciatura, em Matemática e Física, sendo que os acadêmicos desses cursos também ministram aulas como monitores, orientam nossos alunos do ensino médio e estimulam que os monitores possam ingressar nas licenciaturas como forma de verticalização do ensino.

Desde o ano de 2012, com a criação do curso, até a edição de 2017, tivemos aproximadamente 365 candidatos atendidos e, destes, mais de duzentos ingressaram como alunos no Instituto Federal Farroupilha - campus São Borja, com o auxílio das aulas ministradas pelos monitores, ou seja, por outros alunos. Nesses cinco anos, foram mais de cem alunos envolvidos na execução do projeto, sejam como monitores ou colaboradores na organização. 
O gráfico abaixo demonstra a efetividade do projeto, desdobrado em quantitativo, ano a ano, o número de candidatos que fizeram o curso e o número e a porcentagem de aprovados:

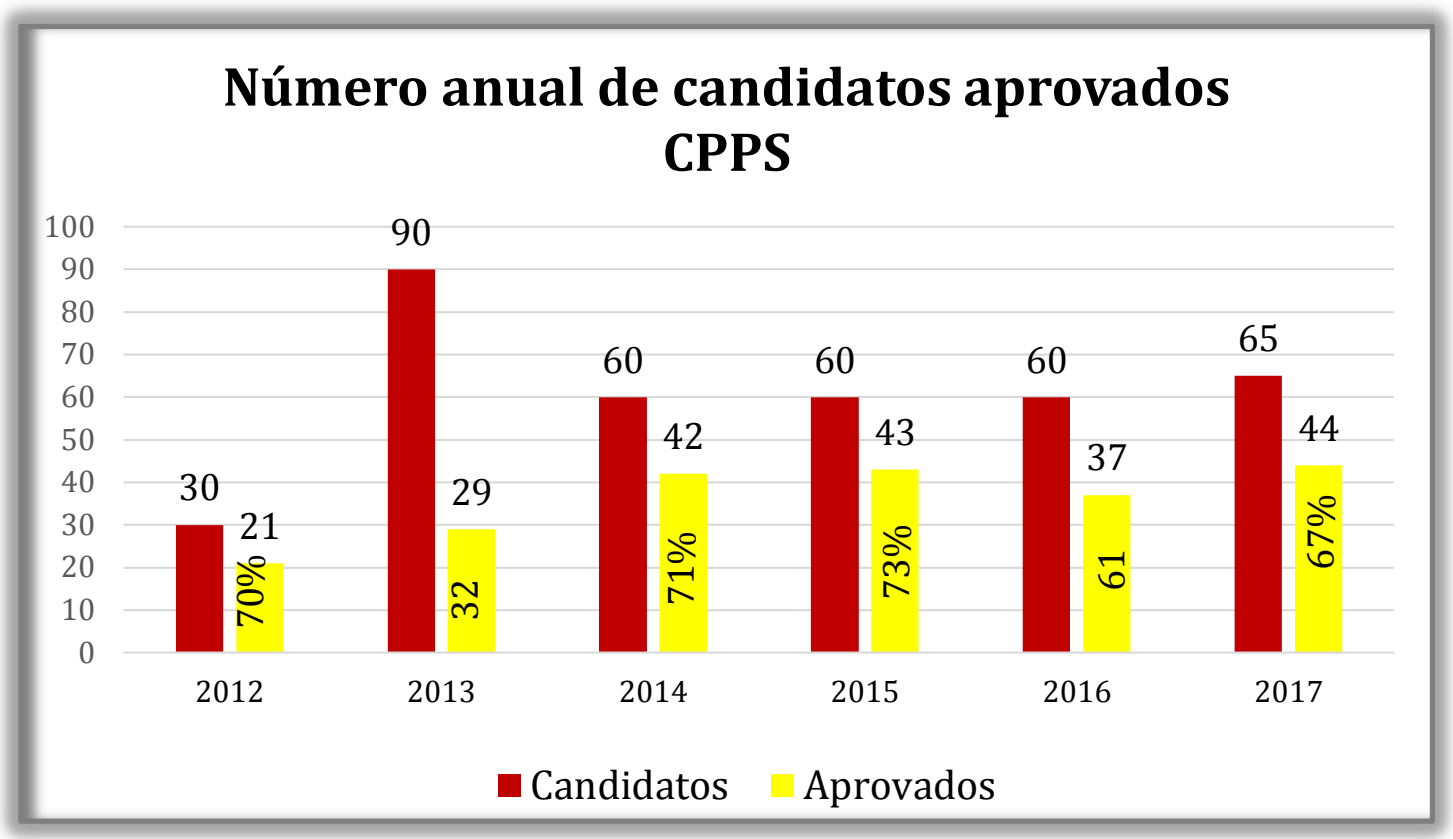

Ao longo desses seis anos, é visível o crescimento e desenvolvimento do projeto, pois o gráfico exibe exatamente essa manutenção de altos índices de aprovação, garantindo assim, a democratização do acesso para alunos de escolas públicas ao Instituto Federal Farroupilha - campus São Borja. Os dados coletados, como podem observar no gráfico, evidenciam que em 2012, dos 30 candidatos que fizeram o curso, 21 foram aprovados(70\%); em 2013 foi ampliado para 90 alunos, em 3 turmas e, desses, 29 foram aprovados(32\%); em 2014, dos 60 candidatos, 42 foram aprovados(71\%); em 2015, dos 60 alunos que fizeram parte do CPPS, 43 foram aprovados(73\%); no ano de 2016, dos 60 candidatos, 37 obtiveram a aprovação(61\%). A partir do ano de 2017 contabilizamos como o total de candidatos apenas os que frequentaram no mínimo $50 \%$ nas aulas, o que altera o percentual de aprovados e, em nosso entendimento, mensura de forma mais fidedigna o impacto do curso para a aprovação dos candidatos. Por isso, em 2017, dos 70 inscritos, apenas 65 finalizaram o curso e destes 44 foram aprovados, totalizando $67 \%$ de aprovação.

Esses dados refletem os altos índices de aprovação e também a importância do CPPS, pois normalmente um terço das 120 vagas ofertadas é preenchido por candidatos que frequentaram o curso. 


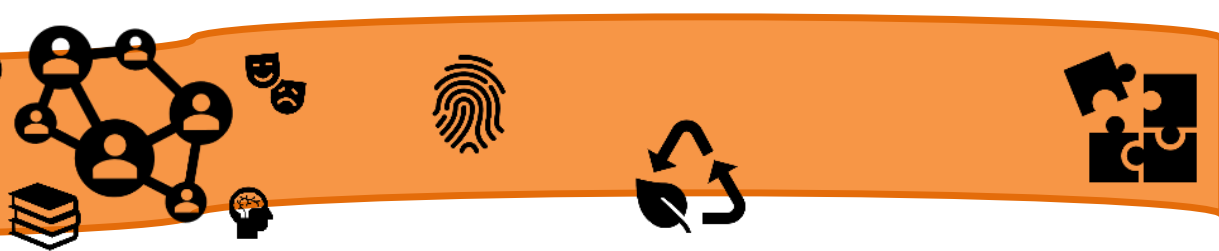

O CPPS cumpre seu papel de extensão no IFFar, pois traz a comunidade para o espaço de educação pública e de qualidade, abre as portas para o público externo à instituição, especialmente os das classes populares, no intuito de contribuir na mudança do seu entorno. Ainda, trabalha com a intenção de auxiliar na obtenção de maiores possibilidades de aprovação na prova do processo seletivo por meio dos conhecimentos que são reforçados no decorrer das aulas que acontecem aos sábados. Tudo isso com base nos componentes curriculares das séries de ensino fundamental, focando nos conteúdos de seu último ano e nos assuntos exigidos pelo processo seletivo.

Considerando os índices de aprovação dos participantes ao longo dos anos e o sentimento de pertencimento ao IFFar que os alunos do CPPS têm após aprovação no processo seletivo, é notório o entendimento de sucesso deste curso durante todos os seis anos de execução. O que corrobora essa afirmativa é que os alunos que entraram no Instituto com auxílio do curso normalmente são voluntários para ministrar aulas no CPPS e ainda, alguns alunos que foram monitores, acabam seguindo a carreira do magistério.

Outro aspecto de extrema relevância diz respeito ao protagonismo do projeto, que é praticamente todo realizado pelos alunos do campus, cabendo aos professores o papel de orientadores e da coordenação do projeto o gerenciamento das atividades. Este movimento desperta lideranças, encoraja a autonomia nos estudantes e favorece um contato com a realidade da comunidade a qual eles pertencem, reforçando a possibilidade e a necessidade de transformação das nossas realidades.

\section{REFERÊNCIAS}

BRANDÃO, Carlos Rodrigues. O que é educação popular. São Paulo: Brasiliense, 2006.

FREIRE, Paulo. Pedagogia da autonomia: saberes necessários à prática educativa. São Paulo: Paz e Terra, 1996.

Pedagogia do Oprimido. Rio de Janeiro: Paz e Terra, 2005, 42. ${ }^{a}$ Edição. NASCIMENTO, Alexandre do. Universidade e Cidadania: O movimento dos Cursos Pré-Vestibulares Populares. Revista Lugar Comum: Estudos de Mídia, Cultura e Democracia, ${ }^{\circ}$ 17, Rio de Janeiro, 2002. 

nos mapas a seguir.
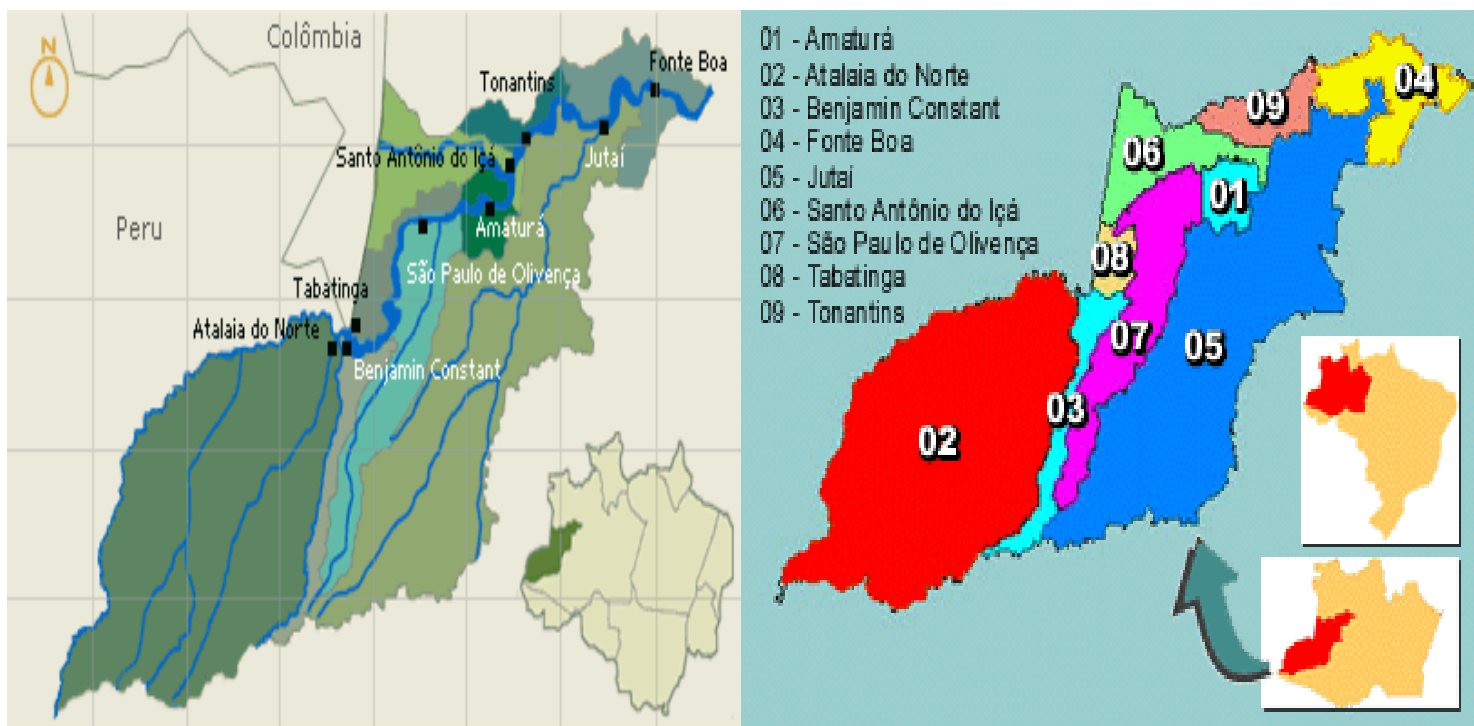

Imagem 1, 2: Mapa dos municípios da mesorregião do Alto Solimões

Fonte: Disponível em <ttps://www.google.com/search?q=Mapa, 2019>. Acesso em 20 de março de 2019.

O Censo do IBGE - 2010, sinaliza que a Região Norte, historicamente, vem mantendo a maior concentração indígenas, cerca de 48,6\% aproximadamente. O Estado do Amazonas possui a maior população autodeclarada indígena do País, com 168,7 mil. Todavia Coelho (1970) diz que os diversos grupos étnicos deram origem a tão numerosas e complexas combinações, sendo impossível chegar a uma classificação étnica dos brasileiros visto os 168,7 mil indígenas.

É de suma importância ressaltar que a dimensão das Terras Indígenas constitui elemento central nas formas de sobrevivência física e cultural das diversas etnias e grupos indígenas que aqui habitam na linha de fronteira.

Censo IBGE, (2010) aponta que:

O conjunto dos 10 municípios com maior população indígena reúne 126,6 mil indígenas, correspondendo a 15,5\% do total de indígenas do País, e metade possui população superior a 10 mil indígenas. Os cinco municípios mais populosos desse conjunto são os seguintes: São Gabriel da Cachoeira (Amazonas); São Paulo de Olivença (Amazonas); Tabatinga (Amazonas); São Paulo (São Paulo); e Santa Isabel do Rio Negro (Amazonas).

Dois desses municípios com maior população indígenas encontram-se na microrregião do Alto Solimões, a saber: São Paulo de Olivença e Tabatinga. Havendo, 


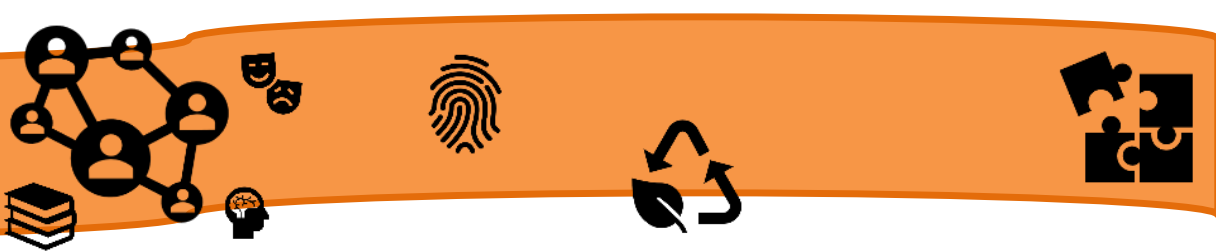

A pesquisa da Andifes aponta que na região Norte em cada 10 (dez) estudantes 7 (sete) são de baixa renda. O Plano Nacional de Assistência Estudantil (Pnaes) ${ }^{22}$, tem seu programa de política voltada para apoiar alunos de graduação em situação de vulnerabilidade socioeconômica, Marcos foi um dos comtemplados.

No entanto, apesar dos avanços da política em assistência estudantil, não se pode negligenciar as possibilidades de investimento na educação superior. Mais investimentos são necessários para se garantir o direito à permanência na universidade. Infelizmente a conjuntura política atual ameaça o incentivo a esses tipos de assistência ao estudante na perspectiva de conclusão da garantia do direito ao ensino superior.

Segundo a pesquisa da Andifes ${ }^{23}$ (2019),

O Perfil Socioeconômico e Cultural dos Estudantes de Graduação das Universidades Federais mostrou também que boa parte dos alunos da instituição veio do ensino público que é o caso de alunos com uma renda de menos de um salário mínimo (em torno de $\mathrm{R} \$ 884,24$ ). Em todo o Brasil, o levantamento feito com aproximadamente $35,34 \%$ dos estudantes revelou que $64,7 \%$ deles estudaram integralmente em escolas públicas de ensino médio, enquanto $35,3 \%$ vieram do ensino particular

No Amazonas a vulnerabilidade socioeconômica atinge as famílias, em sua maioria Indígena, uma vez que nesta região, as oportunidades de empregos são raros, não tem grandes industrias, fábricas para ofertar empregos, grande parte da população sobrevive do cultivo da roça, pesca, caça, do extrativismo e piscicultura.

Com isso, os $80 \%$ dos alunos mencionados na pesquisa é o reflexo da falta de oportunidade ao emprego. A renda per capta familiar é de até um salário mínimo, esse dinheiro fica inviável para assegurar a permanência de alunos como a de Marcos na universidade, pois precisa-se do dinheiro para arcar com as despesas, como por exemplo, aluguel, água, luz como também a compra de materiais didáticos.

Marcos, ao se pronunciar sobre as mudanças em sua vida ao ser contemplado pelo Pnaes, expressou que "o auxílio financeiro veio realmente assegurar minha

\footnotetext{
${ }^{22}$ O Plano Nacional de Assistência Estudantil (Pnaes) apoia a permanência de estudantes de baixa renda matriculados em cursos de graduação presencial das instituições federais de ensino superior (Ifes). Portaria normativa $\mathrm{n}^{\mathrm{o}}$ 39, de 12 de dezembro de 2007. Decreto $\mathrm{n}^{\mathrm{o}} 7.234$, de 19 de julho de $2010-$ portal.mec.gov.br/pnaes.

${ }^{23}$ Associação Nacional dos Dirigentes das Instituições Federais de Ensino Superior (Andifes). Entidade de fomento à pesquisa e levantamento Universitária.
} 


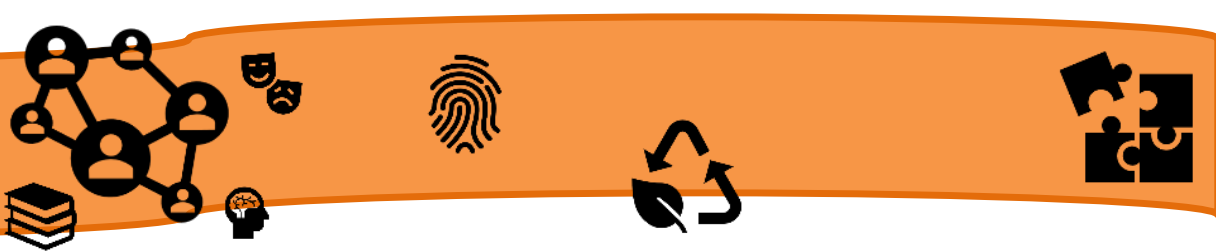

permanência, uma vez que se dependesse apenas da ajuda financeira dos meus pais não teria condições de continuar os estudos" (Caderno de Campo, 2018).

A maioria dos pais dos alunos Indígenas são analfabetos em sua língua materna e segunda língua a portuguesa. Marcos da etnia Tikuna, tem enfrentado ao longo de sua vida acadêmica dificuldades com a escrita tanto na língua Tikuna quanto na língua portuguesa. A questão da escrita padrão exigida pela academia tem sido um dos maiores problemas e desafios não só para os indígenas, mas também para as universidades.

O Instituto de Natureza e Cultura - INC na tríplice fronteira, ainda não se sente preparada para lidar com a imensa diversidade étnica sociocultural do Alto Solimões. É extremante necessário uma metodologia do ensino superior que consiga não só incluir os alunos indígenas, mas ir além e contribuir socialmente com o processo de construção da escrita das diferentes línguas indígenas na perspectiva da formação profissional dos alunos indígenas e da valorização das tradições culturais.

\section{DIÁLOGO INTERCULTURAL UNIVERSITÁRIO: REALIZAÇÃO E RESULTADOS}

O primeiro Diálogo Intercultural Universitários foi um movimento estudantil sediado no Instituto de Natureza e Cultura - INC, pólo da Universidade Federal do Amazonas - UFAM no Alto Solimões, sediado em Benjamin Constant-AM. O referido município fica a uma distância de $1.119 .91 \mathrm{~km}$ aproximadamente em linha reta da capital Manaus.

O evento contou com a participação direta de mais de trezentos e setenta (trezentos e setenta) alunos indígenas, contanto também com a participação de alunos não indígenas dos 6 (seis) cursos de graduação, a saber: Pedagogia, Letras, Biologia e Química, Antropologia, Ciências Agrárias, Administração.

Nos cursos do INC temos alunos matriculados das etnias, a saber: Tikuna, Kokama, Witoto, Mayoruna, Marubo, Kanamari e Kambéba. Essas etnias encontram-se ao largo da região do Alto Solimões, nas margens do rio Solimões e do rio do Vale do Javari, algumas com suas tradições culturais preservadas e praticadas, como os Ticunas, Marubo, Kanamari e, outras em processo de resgate de sua cultura perdida, resultado da colonização européia, como por exemplo, os Kokamas. 


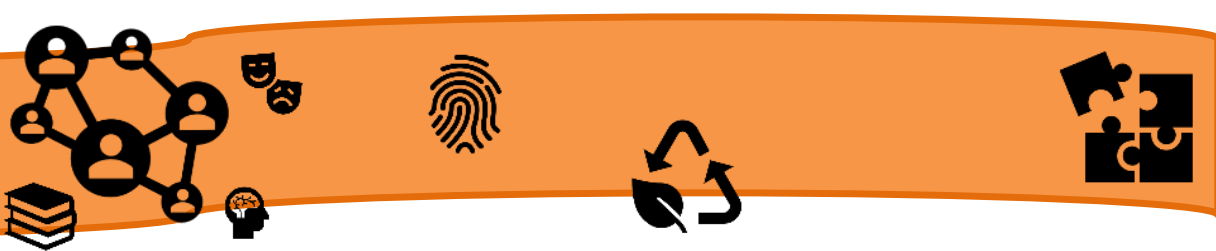

O tema diálogo intercultural na academia proposto pelos acadêmicos indígenas, perpassou pela ideia de uma ação, movimento social dos indígenas de etnias diferentes que pudessem oportunizar uma reflexão mais aprofundada sobre as experiências como alunos indígenas na academia, suas trajetórias, dificuldades e perspectivas de desenvolvimento de suas autonomias intelectuais

Os movimentos sociais de natureza educacional para Fleuri (2003, p. 16 - 35):

[...] propõem uma convivência, no sentido de construir referenciais epistemológicos pertinentes, e dessa forma o trabalho intercultural pretende contribuir para superar tanto a atitude de medo quanto a de indiferente tolerância ante o "outro", construindo uma disponibilidade para a leitura positiva da pluralidade social e cultural. Trata-se, na realidade, de um ponto de vista baseado no respeito à diferença, que se concretiza no reconhecimento da paridade de direitos.

Para o autor a convivência é de suma relevância no processo da construção de um pensamento social de respeito às diferenças, principalmente em se tratando de realidades socioculturais tão diversas.

O Evento foi realizado em 11 (onze) de maio de 2018 no Instituto de Natureza e Cultura. De 1.338 alunos matriculados cerca de 448 eram alunos autodeclarados indígenas, um quantitativo significativo que permitiu a mobilização inicialmente de lideranças discentes indígenas e posteriormente demais alunos.

A organização e preparação do evento possibilitou a experiência de diálogos com outras instituições da sociedade civil e organizada. A parceria interinstitucional foi um dos conceitos trabalhados teoricamente e praticamente pelos discentes e todos os envolvidos no evento.

Assim o evento se concretizou pelas parcerias firmadas com entidades governamentais e não governamentais da região. Entre as instituições parceiras se fizeram presentes a coordenação da Fundação Nacional do Índio - FUNAI do Alto Solimões, Secretaria Especial de Saúde Indígena - SESAI, Rádio - FM local, Prefeitura Municipal, Secretaria de Cultura, Participação de alunos indígenas egressos, Associações, Grupos de danças Indígenas, Cantores Indígenas da Região.

Ressalta-se que todas as instituições foram imprescindíveis para a realização do Diálogo Intercultural Universitário. O encontro promoveu articulações diretas dos acadêmicos com representantes institucionais, fortalecendo os vínculos e as relações sociais que permitiram realização de convênios para realização de estágios 
supervisionados obrigados, como também a possibilidade de apoio aos acadêmicos indígenas em pesquisas e mesmo com o mercado de trabalho.

O Diálogo Intercultural apresentou como resultados a ampla discussão sobre a situação de alunos indígenas que se vieram de suas comunidades para a cidade de Benjamin Constant - AM, distante de seus municípios de origem. Nesse espectro pautou-se a reflexão sobre as mudanças das identidades culturais dos alunos indígenas, vejamos as palavras de Júlio (24 anos, caderno de campo, 2018):

Não é porque saímos de nossas aldeias e passamos a viver na cidade que deixamos de ser índio Ticuna. Não é porque a gente fala português, ou tem um celular que deixamos nossa cultura como muitos brancos pensam. A língua portuguesa é nossa segunda língua, a primeira língua é a materna. A universidade promove mudanças bem como possibilita a gente a crescer, a entender mais as coisas do mundo do branco, e o que aprendemos aqui vai nos ajudar a fortalecer a nossa cultura e nos ajuda em nossas escolhas, sejam elas boas ou ruins.

O evento do I Diálogo contou com atividades que vieram socializar, valorizar e fortalecer os saberes tradicionais indígenas. Para isto, utilizou-se de exibição de Filmes sobre a Campanha de Mobilização Nacional Indígena 2018, apoiados pelo Cine Club Itinerante, projeto de cinema e Educação do INC. Tivemos exposição de artesanatos indígenas das artesãs da comunidade Indígena Porto Cordeirinho em Benjamin Constant $-\mathrm{AM}$.

Tivemos palestras acerca da temática das artes indígenas, como Pinturas e Grafismos indígenas; gravuras em madeira; pintura corporal; socialização das línguas Indígenas existente na fronteira; participação de músicos indígenas e não indígenas com danças típicas, movimentos corporais; Chá Cultural/Danças e músicas culturais.

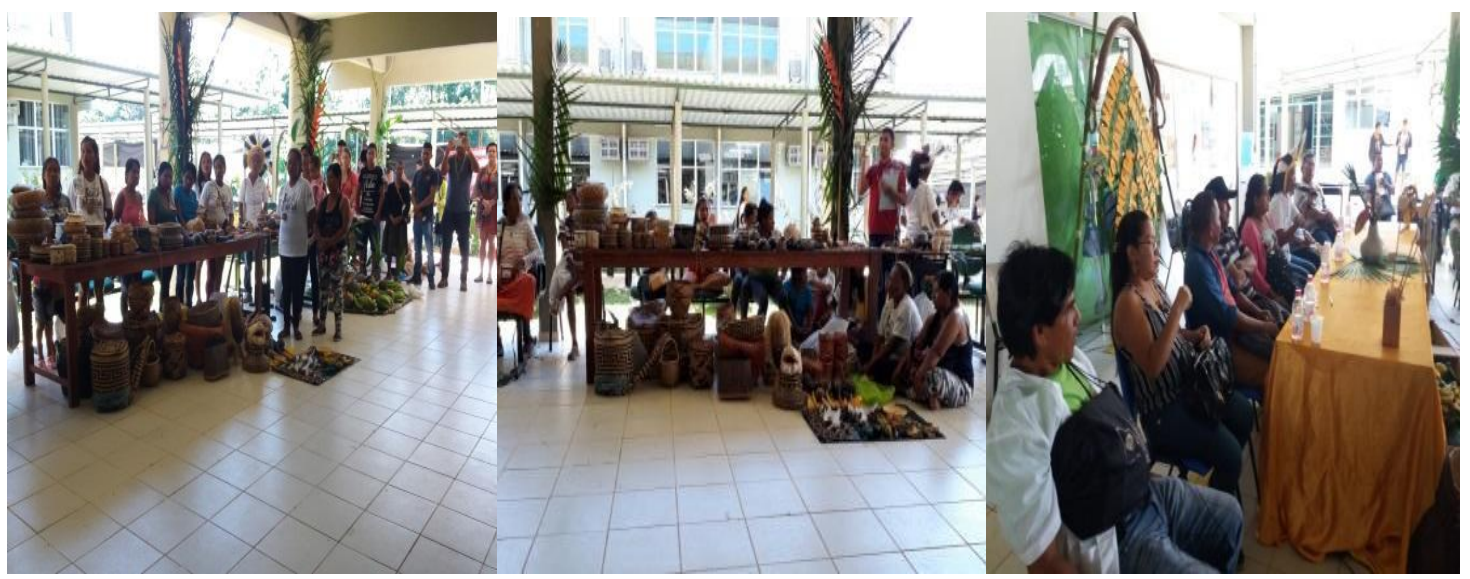

Imagens 3, 4 e 5: imagens 3 e 4 artesãs indígenas e 5 lideranças indígenas do Alto Solimões/AM Fonte: GOMES, Kaio Anderson Fernandes, 2018. 


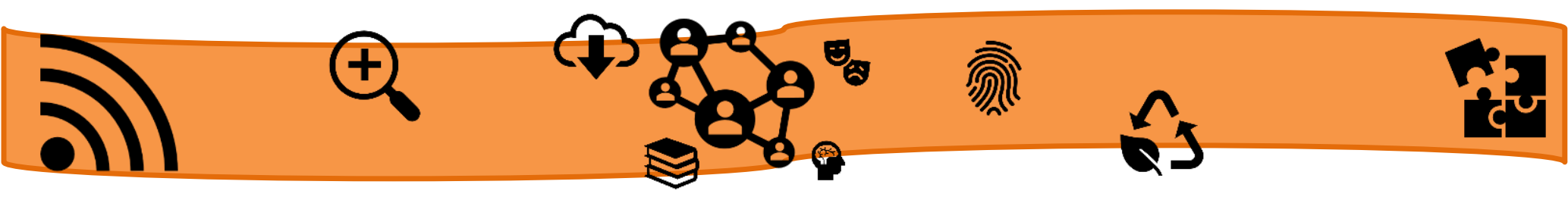

Outra metodologia utilizada foram as Mesas Redondas, envolvendo Lideranças Indígenas como conferencistas, os quais abordaram suas histórias de lutas, resistências e o protagonismo no contexto do Alto Solimões.

As mesas redondas promoveram ainda, a participação de egressos indígenas do INC, os quais abordaram suas experiências na academia, incentivando alunos Indígenas a serem protagonistas no ensino, pesquisa e extensão.

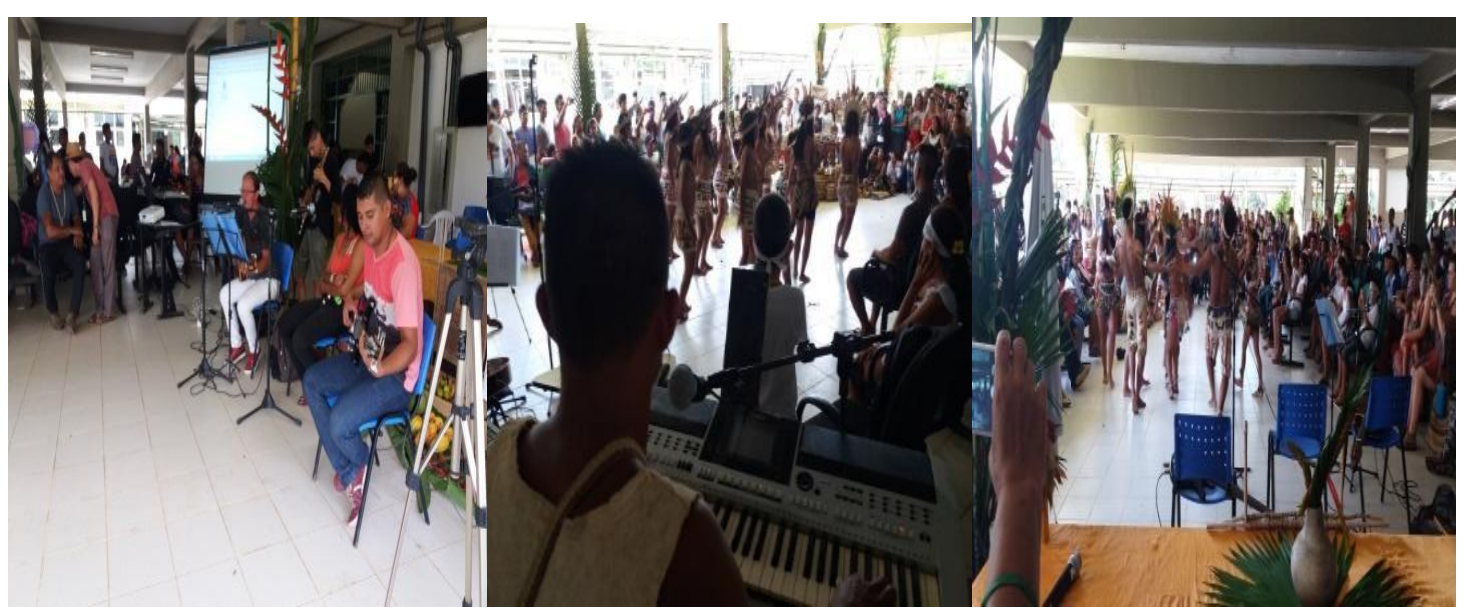

Imagens6, 7 e 8: 6 músicos não indígenas, 7 músico indígena e 8 grupos de danças indígenas Fonte: GOMES, Kaio Anderson Fernandes, 2018.

Discutiu-se sobre os saberes Milenares Indígenas, como por exemplo remédios, culinárias e artesanato promovendo a relevância e articulação entre os conhecimentos científicos e tradicionais.

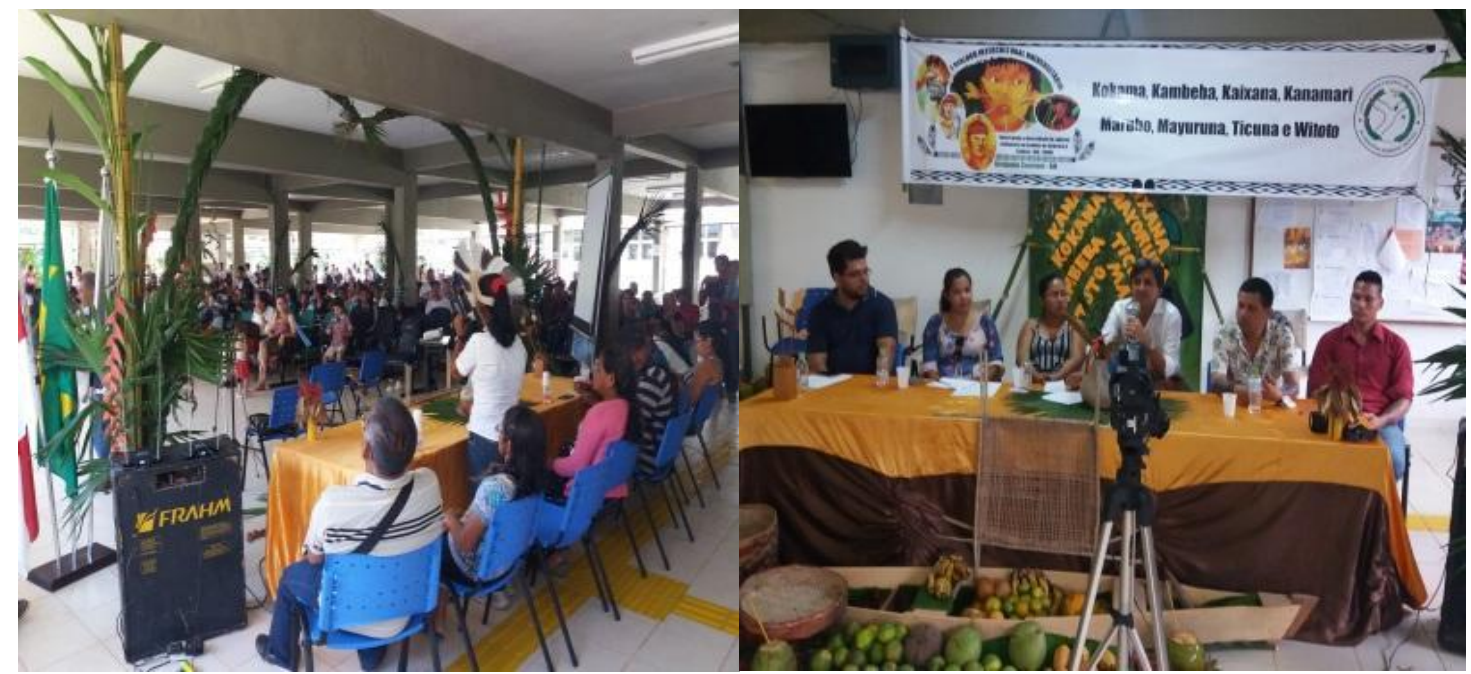

Imagens 9 e 10: 9 mesa redonda - saberes empíricos comunitários de líderes indígenas e 10 discussão dos saberes científico por meio de professore e alunos egressos.

Fonte: GOMES, Kaio Anderson Fernandes, 2018. 


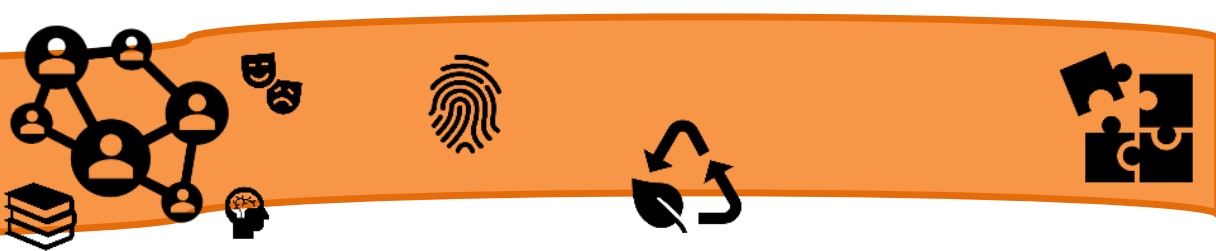

A Proposta de Políticas Públicas Indígenas para o INC/UFAM foi muito discutida, uma vez que as lideranças indígenas e lideranças universitária definiram proposituras para melhor atender os alunos, culminando em um documento final a ser enviado aos órgãos governamentais.

O Diálogo Intercultural permitiu a construção de uma ideia de defesa de uma educação que tenha como pautada no diálogo, respeito às diferenças e não como ressalta Keim (2009) quando na dimensão das diferenças todos estão inseridos e incluídos. Para Silva (2013, p. 41),

cada cultura tem suas próprias e distintivas formas de classificar o mundo e classificar significa estabelecer uma metodologia com critérios e parâmetros em torno dos quais, cada elemento, pode ser incluído em determinado contexto e circunstância.

Portanto, o diálogo tem sido um dos grandes elementos articuladores em todo processo democrático, visto atender a tolerância, o respeito nas várias maneiras e formas do pensar, como também no externar os vários posicionamentos divergentes entre nações, povos e crenças que em sua grande maioria tem sido resultante na concretização do bem comum.

Nesse contexto, a universidade na fronteira: Brasil, Peru e Colômbia tem o desafio de formar a nível superior acadêmicos indígenas e não indígenas, preparando-os para participação nas questões que dizem respeito aos seus modos de vida na região e no mundo, enfatizando e articulando suas experiências teóricas e práticas.

Hedegaard, (2002, p. 199-228) argumenta que:

O conhecimento empírico tem a ver com diferenças e semelhanças entre os fenômenos, estes que, surgem por meio da observação e comparação ordenada hierarquicamente com base em características formais; e a palavra ou um termo limitado é o meio pelo qual ele é comunicado.

Discutir a formação dos discentes indígenas sem abandonar o rigor metodológico e o instrumental teórico científico, construindo com as políticas públicas por meio do conhecimento em diálogo e, com os modelos cognitivos desses povos indígenas e não indígenas, foram os objetivos do evento. Visto as diversidades socioculturais na região do Alto Solimões - AM: 


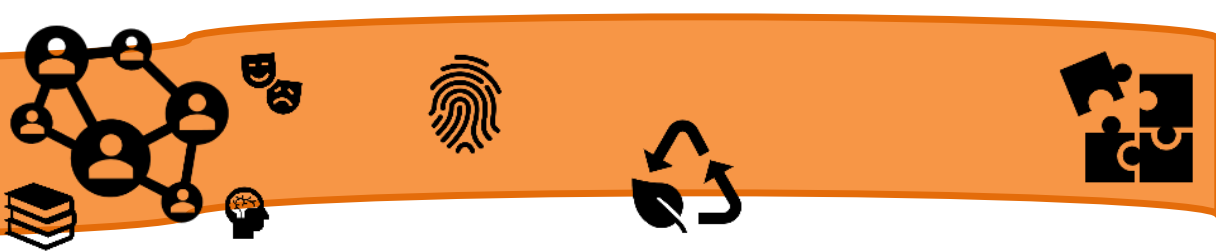

A sociedade se comporta como processo ecodesorganitivo organizativo pelo fato de ser impossível estabelecer pontos de partida ou de chegada pois são incontáveis as interações e intervenções que ocorrem a todo o tempo no contexto das relações humanas e sociais (KEIM, 2008, p. 45).

A troca de conhecimentos científicos e empíricos, promovida pelo diálogo intercultural promoveu espaços de valorização das diferenças, respeito aos saberes, às formas de expressar pensamentos por meio da língua materna. Permitiu, formas peculiares de fortalecer a identidade dos grupos étnicos, reconhecer as diferenças entre eles, as relações dialógicas como condição para a promoção de um crescimento intelectual.

\section{CONSIDERAÇÕES FINAIS}

O evento permitiu pela primeira vez no Alto Solimões um encontro entre diferentes lideranças indígenas da região em conjunto com órgãos governamentais e não governamentais construindo-se um panorama da vida dos diferentes grupos sociais étnicos.

O Diálogo Intercultural Universitário trouxe contribuições significativas para o universo acadêmico indígena, mas também para a sociedade na Tríplice fronteira, principalmente no campo da reflexão e discussão para a promoção de políticas públicas específicas na garantia dos direitos às diferenças dos indígenas.

A discussão sobre o papel social da universidade no Alto Solimões foi um dos resultados importantes para se contribuir cientificamente com a promoção das culturas indígenas e seus saberes tradicionais de diferentes aspectos, seja do social, cultural e econômico. A proximidade das pessoas à universidade e a universidade das pessoas tem fomentado políticas de cooperação seja por meio do ensino, pesquisa ou extensão.

Portanto, apesar dos avanços a instituição superior precisa de novas políticas públicas para atender com mais ênfase as dificuldades enfrentadas, principalmente por alunos indígenas no campus Universitário de Benjamin Constant. Muitos alunos Indígenas têm evadido, uma vez que não conseguem acompanhar os estudos e conteúdos ministrados na graduação, na grande maioria a dificuldade está em assimilar e interpretar o que é ministrado pelos professores. 


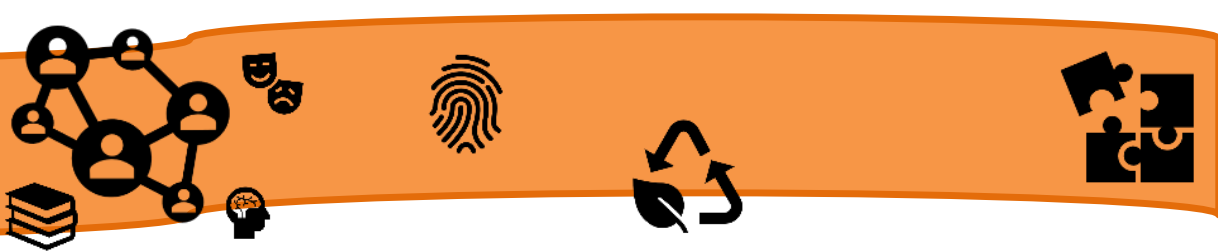

KEIM, Ernesto Jacob. Educação Ambiental e Sustentabilidade. Blumenau, FURB texto presente nos materiais do curso a distância "Educação Ambiental e Sustentabilidade, ainda não disponível para consulta pelos não inscritos no curso. 2009.

Portal Acrítica. Pesquisa aponta mais de 80 dos alunos da ufam em vulnerabilidade socioeconômica. Disponível em: https://www.acritica.com/channels/manaus/news/pesquisa-aponta-mais-de-80-dosalunos-da-ufam-em-vulnerabilidade-socioeconomica. Consultado em 10 de dezembro de 2018.

Portal Google. Lei Do PENAES. Disponível em: https://www.google.com/search?q=LEI+DO+PENAES\&oq=LEI+DO+PENAES\&aqs= chrome..69i57.8176j1j7\&sourceid=chrome\&ie=UTF-8. Consultado em 10 de dezembro de 2018.

Portal Google. Lista de mesorregiões e microrregiões do Amazonas. Disponível em: ttps://www.google.com/search?q=Mapa+dos+municípios+da+mesorregião+do+Alto+S olimões+sudoeste+do+Amazonas\&tbm $=$ isch\&source $=i u \& i c t x=1 \&$ fir $=$ ZVWcsjx YIIDkP M\%. Consultado em 10 de dezembro de 2018.

Portal Wikipedia. Caça ao Tesouro - Estado do Amazonas. Disponível em: https://pt.wikipedia.org/wiki/Lista_de_munic\%C3\%ADpios_do_Amazonas_por_popula \%C3\%A7\%C3\%A3o. Consultado em 10 de dezembro de 2018.

SILVA, Marilene Corrêa. Metamorfose da Amazônia. 2. ed. Manaus: Universidade Federal do Amazonas, 2013. 


\title{
DOCUMENTO CURRICULAR DO RN - ENSINO FUNDAMENTAL: A EXPERIÊNCIA DOS REDATORES DE MATEMÁTICA
}

\author{
OLIVEIRA, José Damião Souza de $\mathrm{de}^{24}$ \\ SOUZA, Josenildo Gomes de Oliveira ${ }^{25}$ \\ ANDRADE, Luciana Vieira ${ }^{26}$
}

\section{RESUMO:}

Este resumo apresenta elementos de um relato de experiência dos professores de Matemática que atuaram como redatores do Documento Curricular do Estado do Rio Grande do Norte (RN) para o Ensino Fundamental (EF). Tendo em vista a homologação da Base Nacional Comum Curricular (BNCC) do EF, em dezembro de 2017, e posterior lançamento do Guia de Implementação da BNCC, pelo Consed e Undime, ações referentes à organização das secretarias estaduais e municipais de educação, via MEC, foram sendo delineadas para se efetivar a aplicação da Base nas escolas. Dentre estas ações, destaca-se o trabalho desenvolvido a partir do Programa de Apoio à Implementação da BNCC (ProBNCC). Embora a BNCC traga as aprendizagens essenciais esperadas dos componentes curriculares em cada ano de escolaridade, ela não define quais metodologias os docentes devem aplicar. Nesse sentido, o referido Programa estabelece como uma de suas principais frentes, a (re)elaboração dos currículos estaduais, a partir do que está posto no documento nacional. No decorrer do ano 2018, a produção do currículo aconteceu por meio de um grupo de especialistas das diversas áreas de ensino, coordenado por profissionais da Educação que representaram o Consed e a Undime, garantindo um trabalho realizado em regime de colaboração entre as redes estaduais e municipais do RN. Para articular esta elaboração e fundamentar os profissionais que se responsabilizariam por esta escrita, algumas formações foram desenvolvidas pelo MEC. Nestes momentos, redatores e coordenadores de todos os Estados da Federação tiveram a possibilidade de trocar experiências e de socializar informações sobre o andamento de seus trabalhos. Paralelo à tais formações, os documentos curriculares estaduais iam sendo elaborados. No RN, com uma versão preliminar do documento já produzida, aconteceram seminários de mobilização, direcionados aos coordenadores pedagógicos das escolas estaduais e gestores municipais, a fim de orientá-los quanto à consulta pública que aconteceria em seguida, de modo que estes atuariam como multiplicadores em suas escolas e/ou municípios, orientando, posteriormente, os professores a contribuírem com esse trabalho. A partir daí, durante um mês, foi disponibilizada uma plataforma digital em que todos da sociedade puderam ter acesso à versão preliminar para apreciação e inserção de contribuições em todos os componentes curriculares. Finalizada a consulta pública, houve um período dedicado à categorização das contribuições e, então, a consolidação do documento curricular. Uma nova etapa de seminários aconteceu, com o intuito de

\footnotetext{
24 Mestre em Ensino de Ciências Naturais e Matemática, IFESP/ SEEC-RN. E-mail: damiaomatematica@ifesp.edu.br

${ }^{25}$ Especialista em Ensino da Matemática, SEEC-RN. E-mail: jnildogomes@gmail.com

${ }^{26}$ Mestra em Ensino de Ciências Naturais e Matemática, SEEC-RN. E-mail: luvieira13@gmail.com
} 
considerados relevantes para o desenvolvimento de habilidades e competências (SEEC-RN, 2018, p. 15).

Com o currículo como evento social e que, portanto, reflete escolhas sociais conscientes, como afirma Sacristán (2000), a sua efetivação na vivência escolar requer que alunos, professores, gestores, coordenadores, enfim todos que compõem a comunidade escolar, realizem um trabalho que dialogue com esta perspectiva. Isso implica a necessidade de um currículo dinâmico, contextualizado e que expresse o “momento sociocultural e a prática educativa nele inserida", como afirma D' Ambrosio (2012, p. 81).

Ao pensar em práticas educativas, a Matemática vem como produção humana e, portanto, "possibilita à sociedade apoderar-se das ideias matemáticas construídas nos diferentes momentos e em diferentes contextos sócio-culturais" (MENDES, 2009, p. 6). Assim, propomos uma Matemática para Educação Básica do RN com um papel social e cultural na formação do estudante, como elemento da sociedade contemporânea, ideia esta presente no Documento Curricular estadual, a ser materializado nas salas de aula.

Nessa perspectiva, as mudanças sociais e o rápido desenvolvimento tecnológico nos apontam a necessidade de uma verdadeira (re)significação do ensino da Matemática e, então, o ensino por competências e habilidades vêm como perspectiva pedagógica promissora, conforme fala Moretto (2002, p. 18) "os rumos da educação para o momento social atual se voltam para novo foco: o desenvolvimento de competências em vários campos do saber".

Neste sentido, entendemos competências como defendido por Perrenoud (1999, p. 7), "Capacidade de agir eficazmente em um determinado tipo de situação, apoiada em conhecimentos, mas sem limitar-se a eles" ou a forma eficaz de enfrentar situações análogas, de modo a articular a consciência e recursos cognitivos com saberes, capacidades, atitudes, informações e valores, tudo isso de maneira rápida, criativa e conexa. Dessa forma, é a articulação entre conhecimentos, valores e atitudes que irá favorecer o desenvolvimento das competências, que não são inatas em um indivíduo e sim podem ser construídas e desenvolvidas, como dizem Silva e Felicetti (2014, p. 19).

É sabido, que na área da educação, ao tratarmos do ensino por competências, estas devem ser desenvolvidas a partir de habilidades construídas, isto é, uma competência se adquire quando o individuo constrói um conjunto de habilidades. A 


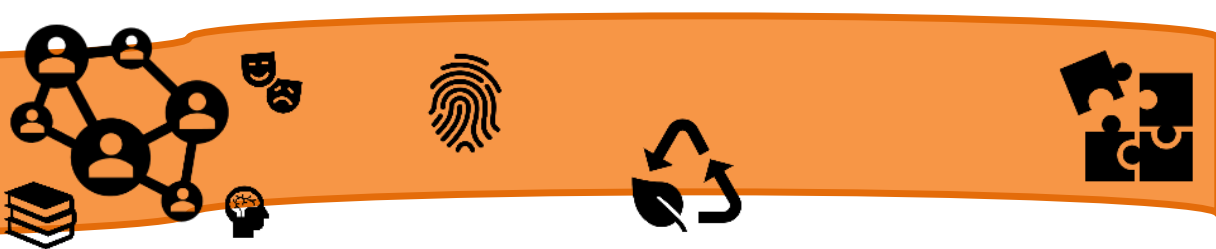

respeito disso o Documento Curricular do $\mathrm{RN}$ propõe para os alunos da Educação Básica: '[...] o desenvolvimento de habilidades e competências que são acionadas por eles na tomada de decisões, na resolução de problemas presentes na vida cotidiana, no mundo do trabalho e no exercício pleno da cidadania" (SEEC-RN, 2018, p. 15).

A BNCC também sugere o ensino por meio de competências e habilidades e apresenta as definições:

[...] competência é definida como a mobilização de conhecimentos (conceitos e procedimentos), habilidades (práticas, cognitivas e socioemocionais), atitudes e valores para resolver demandas complexas da vida cotidiana, do pleno exercício da cidadania e do mundo do trabalho. (BRASIL, 2017, p. 8)

Com relação às habilidades, o documento nacional entende que "[...] expressam as aprendizagens essenciais que devem ser asseguradas aos alunos nos diferentes contextos escolares.” (BRASIL, 2017, p. 29), refere-se às aprendizagens fundamentais esperadas para cada componente curricular e ano.

Sobre isso, Moretto (2002, p. 21) diz que:

[...] de maneira geral associaremos o termo habilidade ao 'saber fazer' algo específico. Isto significa que eles estarão sempre associados a uma ação, física ou mental, indicadora de uma capacidade adquirida. Assim, identificar, relacionar, correlacionar, aplicar, analisar, avaliar, manipular com destreza são verbos que podem indicar habilidade do sujeito em campos específicos.

Esta citação nos remete ao pensamento de que habilidade não é necessariamente algo inerente ao ser humano, mas que pode ser desenvolvido, aprimorado, para assim alcançar competências.

De acordo com Silva e Felicetti (2014), o trabalho por competências e habilidades, na Educação Básica, resulta em importantes aspectos para a vida em sociedade. Estas autoras também apontam que os sistemas nacionais de avaliação como, por exemplo, o SAEB, vislumbram o desenvolvimento de habilidades e competências.

A partir dessa ideia de contribuir com aspectos relativos à vida em sociedade, a Matemática, por possibilitar aplicações nos variados campos do conhecimento, confirma nosso entendimento de que a área é resultante da produção humana, ou seja, como ciência que não está pronta e acabada nem é composta por verdades absolutas, mas está em constante transformação. 


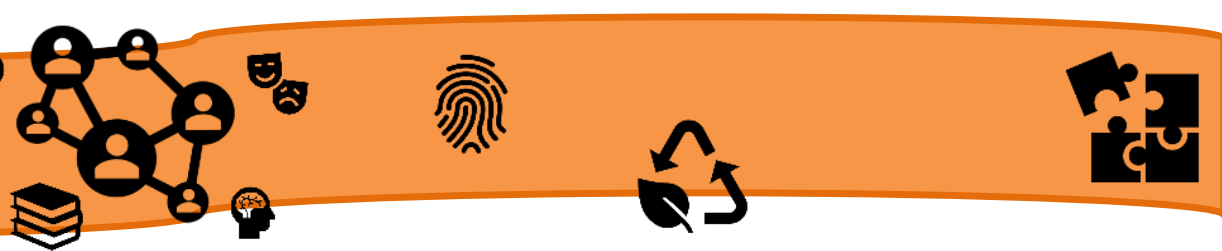

Assim, a escola deve se encarregar de propiciar aos estudantes vivências às quais seja possível o desenvolvimento de habilidades relativas ao uso e entendimento da Matemática na escola, na vida pessoal e, entre outras coisas, na vida profissional, por meio do raciocínio empenhado que se efetiva pelo exercício criativo da intuição e da imaginação. Sobre a Matemática, D’Ambrósio (2012, p. 8) diz que é "uma estratégia desenvolvida pela espécie humana, ao longo da sua história, para explicar, entender e manejar o imaginário e a realidade sensível e perceptível, bem como conviver com eles, evidentemente dentro de um contexto natural e cultural".

Para D’Ambrosio (2012, p. 8), educação é “estratégia de estímulo ao desenvolvimento individual e coletivo gerada pelos grupos culturais, com a finalidade de se manterem como tais, respeitando suas raízes culturais, e de avançarem na satisfação de necessidades de sobrevivência e de transcendência" e ainda "uma estratégia da sociedade para facilitar que cada indivíduo atinja o seu potencial e para estimular cada indivíduo a colaborar com outros em ações comuns na busca do bem comum" (D’AMBROSIO, 2012, p. 63). Nesta direção, incluir as variáveis históricas e sociais no trabalho educacional, possibilita-nos enxergar o ensino da Matemática como importante elemento para uma formação global do indivíduo e, portanto, é conveniente se falar em educação para a cidadania como uma forte premissa.

Isto posto, destacamos que a proposta do Documento Curricular do RN é que, desde os anos iniciais, os estudantes se deparem com atividades de "observar, analisar, estabelecer relações, perceber regularidades e buscar explicações, conjecturar, criar soluções e inventar estratégias próprias que envolvam noções, conceitos e métodos matemáticos" (SEEC-RN, 2018, p. 734).

Para a BNCC, o trabalho a ser desenvolvido na Educação Básica, deve-se pautar na articulação entre os diversos campos da Matemática, entendidos como unidades temáticas: Números, Álgebra, Geometria, Grandezas e Medidas, Probabilidade e Estatística. A nós, cabe informar que

[...] essa divisão em unidades temáticas serve tão somente para facilitar a compreensão dos conjuntos de habilidades e de como eles se inter-relacionam. Na elaboração dos currículos e das propostas pedagógicas, devem ser enfatizadas as articulações das habilidades com as de outras áreas do conhecimento, entre as unidades temáticas e no interior de cada uma delas. (BRASIL, 2017, p. 273). 



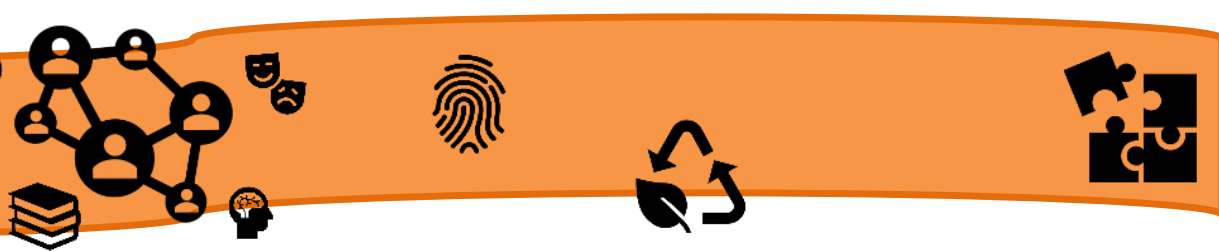

Implementação da BNCC, o Programa de Apoio à Implementação da Base Nacional Comum Curricular (ProBNCC) foi a política pública que propiciou este trabalho. Detalhadamente, a equipe responsável pela elaboração curricular, foi composta por:

- coordenadores estaduais de currículo (um da secretaria estadual, representando o Consed, um da Undime-RN);

- articulador de regime de colaboração representando a Undime-RN;

- um analista de gestão indicado pelo MEC;

- três coordenadores curriculares de etapa de ensino, sendo um para Educação Infantil, um para Anos Iniciais do EF e um para Anos Finais do EF;

- vinte e dois redatores de currículo sendo todos estes professores das redes estadual e municipais do RN.

Para a seleção dos redatores, alguns critérios foram pré-estabelecidos pelo MEC da qual destacamos a obrigatoriedade de estarem em efetivo exercício de suas funções em escolas das redes públicas e que fossem especialistas em suas respectivas áreas. Em se tratando de Matemática, trabalhamos em trio. Os três, atuantes como professores da rede estadual do RN com comprovada experiência na área e formação em nível de pósgraduação, sendo um especialista em Ensino de Matemática e dois mestres em Ensino de Ciências Naturais e Matemática.

No decorrer do citado ano, o MEC propiciou momentos de formações no intuito de articular a elaboração e fundamentar os profissionais envolvidos nesta escrita. Foram ocasiões ricas quanto à troca de experiências entre os profissionais de todos os estados da Federação e que oportunizaram também socializações em relação ao trabalho que estava sendo desenvolvido.

Entre 26 e 28 de março, houve o encontro inicial, em Brasília-DF. As diversas equipes ProBNCC articularam-se em relação à (re)elaboração dos currículos, à luz da BNCC. Foi uma reunião efetivada sob à responsabilidade do MEC em parceria com Consed e Undime e com o apoio da Universidade de Brasília (UnB) em que todas as equipes técnicas e de gestão do Estados brasileiros estiveram presentes.

Após este encontro, efetivamente, os redatores foram delineando a escrita da proposta do Documento Curricular. Para tanto, foram necessários estudos coletivos realizados pelos profissionais das áreas, reuniões entre os participantes do grupo 


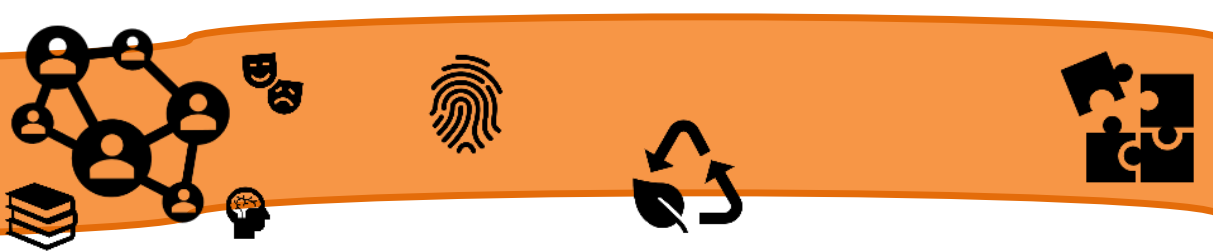

ProBNCC bem como leituras e estudos individuais com reflexões posteriores para alinhamento das ações.

Ao sexto mês de 2018, a SEEC-RN oportunizou encontros de formação para a escrita do currículo, ocasião em que foram discutidas as diretrizes deste trabalho e realizadas socializações do que já havia sido produzido quanto à proposta curricular do $\mathrm{RN}$, para propiciar reflexões e discussões acerca deste. Este evento aconteceu na Escola do Governo e estavam presentes, além dos membros da ProBNCC-RN, representantes da educação do estado e outros professores da rede pública. Aconteceram, na ocasião, palestras e oficinas.

A essa altura, diversas reuniões para discussões já haviam acontecido entre os redatores das áreas, entre estes e os coordenadores de etapa e entre toda a equipe ProBNCC. No caso da Matemática, já havíamos disponibilizado, por meio de um servidor on-line, uma pasta compartilhada entre nós e alimentada a partir das produções que íamos realizando. Tal recurso digital facilitou e agilizou nossa comunicação, pois possibilitou que cada um dos integrantes do grupo tivesse rápido e fácil acesso às escritas dos demais, permitindo, assim, o acompanhamento e a revisão do que todos produziam. De fato, esta possibilidade favoreceu o desenrolar de nosso trabalho em relação à disponibilidade de tempo para encontros presenciais já que continuávamos desenvolvendo nossas atividades regulares de sala de aula.

Por todo o Brasil, paralelo às citadas formações em 2018, os documentos curriculares iam criando corpo. Para o RN, vivíamos um momento histórico, sobretudo porque o que estava sendo produzido era a primeira versão de um documento curricular nesta magnitude que representaria o nosso estado. Até então, o que havia eram portarias que estabeleciam orientações curriculares para algumas modalidades e/ou etapas de ensino. Contudo, alguns municípios já disponibilizavam seus organizadores curriculares.

Para a escrita do capítulo de Matemática, tivemos o cuidado de estudar e entender a proposta da BNCC, com o intuito de compreender os princípios norteadores deste documento normativo e estabelecer diretrizes e concepções que seriam assumidas pelos envolvidos na escrita do Documento Curricular. Assim buscamos produzir um documento que, de fato, representasse nosso estado. Além dos estudos mencionados, foi necessário fortalecer os conhecimentos sobre os procedimentos de avaliação, tendo em 
vista que estaríamos propondo situações para os nove anos do EF, então, realizamos discussões e reflexões sobre processos de avaliação, bem como metodologias, habilidades e exemplos de propostas de trabalho interdisciplinar para podermos introduzir situações e contemplar as diversidades regionais, assim, estabelecemos um modelo para estrutura do documento curricular que se construía.

De posse da versão preliminar do documento, a SEEC-RN realizou seminários de mobilização, direcionados aos coordenadores pedagógicos das escolas estaduais e gestores municipais. Estes aconteceram em julho de 2018 e tinham o objetivo de orientar tais profissionais com relação à consulta pública que aconteceria em seguida. Nestes encontros, apresentamos a plataforma destinada à consulta e orientamos quanto a sua utilização para que coordenadores e gestores atuassem como multiplicadores em suas escolas e/ou municípios, orientando os professores a contribuírem com este trabalho.

Nesse mesmo período, os redatores realizaram versões destes seminários nas escolas onde atuavam a fim de alcançar o maior número possível de educadores e a sociedade civil, pois sabemos que a educação é dever de todos e consideramos que contribuir com a escrita do Documento Curricular do RN seria um interesse coletivo. Com a meta de atingir todo o RN, os seminários foram realizados na capital (Natal), em Mossoró e em Caicó, municípios onde há polos da SEEC-RN. Nestes momentos, atingimos cerca de quatro mil participantes, o que mostra um efetivo interesse dos envolvidos no regime de colaboração.

Para a consulta pública que aconteceu entre 03 e 31 de agosto, foi disponibilizada, após os seminários de mobilização, uma plataforma digital cujo acesso à versão preliminar do Documento estava aberto a todos para apreciação e inserção de contribuições nos diferentes componentes curriculares.

Para análise e divulgação, a versão inicial foi depositada em plataforma on-line e subdivida em seções. A ideia era não ser necessário que os participantes analisassem o Documento na íntegra, assim, um(a) professor(a) do segundo ano do EF, por exemplo, que desejasse analisar e colaborar com apenas este ano de ensino poderia acessar o conteúdo específico e realizar suas contribuições, dedicando-se apenas ao ano de escolaridade de seu interesse. 


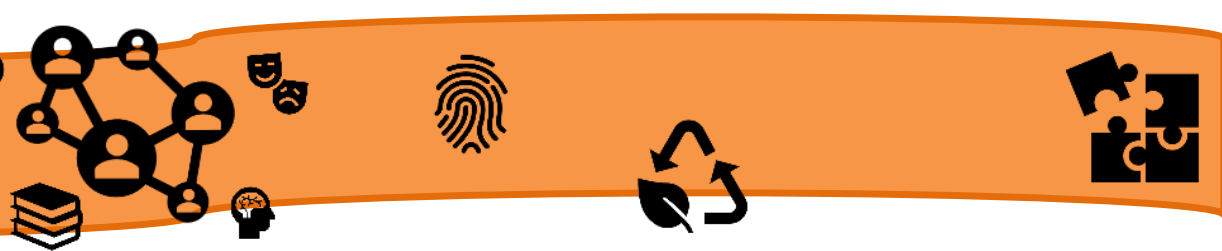

Junto à escrita do Documento que continuava acontecendo, ocorriam reuniões entre os membros da equipe ProBNCC no intuito de discutir e estabelecer os critérios de análise das contribuições oriundas da consulta pública.

Ao final da consulta, a consolidação do Documento Curricular dependia ainda de ações que diziam respeito à categorização das contribuições, a partir dos critérios estabelecidos anteriormente. As contribuições foram analisadas e classificadas quanto ao aceite ou não aceite pelos redatores de cada área. Este trabalho foi realizado em salas da própria SEEC-RN, sob a orientação das coordenadoras de etapa e da analista de gestão.

Destacamos que, no caso específico da Matemática, algumas contribuições foram aceitas integralmente e outras aceitas parcialmente. Estes aceites enriqueceram consideravelmente o Documento visto que tivemos colaborações muito bem pensadas e fundamentadas e que condiziam com nossos pressupostos e com as concepções que defendemos. Além disso, contribuições que traziam características regionais foram percebidas. Feitas as devidas alterações, chegamos a uma nova versão do Documento Curricular, a qual seria enviada para apreciação do Conselho Estadual de Educação (CEE).

Em outubro de 2018, novamente nos mobilizamos para a realização de uma etapa de seminários. Desta vez, para apresentar uma devolutiva sobre a consulta pública. Nestas ocasiões, os profissionais que efetivamente contribuíram foram convidados a participarem de modo que, a eles, foram apresentados resultados da consulta. Abordamos os critérios de análise, os municípios que mais opinaram por componente, a quantidade de participações, entre outros tópicos.

Em nossa área, foram momentos importantes, pois tivemos a oportunidade de discutirmos e refletirmos com nossos pares sobre as concepções de área que assumimos, as concepções de currículo e de ensino em que nos fundamentamos.

Desta vez, os encontros foram realizados em Natal, Caicó e Pau dos Ferros, município este que também sedia um dos polos da SEEC-RN.

Para finalizarmos esse ciclo de atividades o Documento Curricular do RN Ensino Fundamental foi encaminhado ao CEE que, após análise, o aprovou. Esta aprovação possibilitou a publicação e apresentação do Documento à sociedade. 



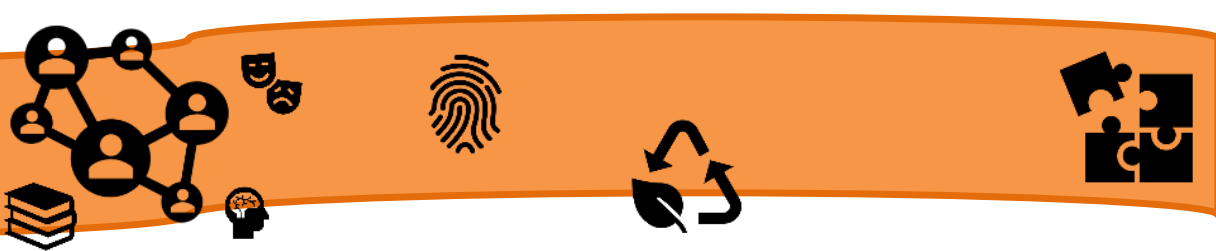

que foram produzidos e ainda para retomar a ideia de que a elaboração da Base aconteceu por meio de um longo processo, com participação de muitos profissionais especialistas em Educação e também da comunidade civil, através de consulta pública.

Nessas etapas das discussões, relacionamos este percurso com o que foi seguido para a elaboração do nosso Documento Estadual. Também falamos sobre as formações que participamos em Brasília/DF, realizadas pelo MEC, retomamos a estrutura da BNCC, e alguns de seus fundamentos pedagógicos como a progressão e as unidades temáticas. Após o relato histórico da construção do Documento Curricular do RN, elencando os tópicos: instituição da equipe ProBNCC, as formações, o processo de escrita, a versão preliminar, a consulta pública, a versão pós contribuições, a homologação do mesmo pelo Conselho Estadual de Educação e o lançamento. Apresentamos a estrutura do quadro organizador curricular e algumas abordagens/concepções do componente Matemática, com ênfase ao ensino da Matemática a partir do desenvolvimento de competências e habilidades e estratégias de aprendizado. Para tanto, refletimos sobre a perspectiva da investigação, resolução de problemas e propomos algumas atividades práticas.

Nossas participações nas escolas, a partir do que apresenta Sacristán (2000, p. 9) quando diz que "as fases ou processos fundamentais por meio dos quais o currículo se conforma como prática realizada num contexto", visaram instaurar as etapas iniciais de formações dos professores quanto à aplicação do currículo em sua prática. Contudo, um plano de formação continuada, de maneira mais ampla, para os docentes das redes estadual e municipal está sendo alinhado pelas equipes responsáveis do MEC e da SEEC-RN a partir das quais estão previstas uma série de ações a acontecerem no decorrer do ano 2019.

\section{CONSIDERAÇÕES FINAIS}

Consideramos neste relato a importância de divulgar, à comunidade da Educação Matemática, os meios e/ou caminhos trilhados pelos redatores do Documento Curricular do RN para o EF, na área da Matemática. A ideia foi esclarecer sobre qual o sujeito que se quer formar, quais os elementos que relacionam o Documento Curricular do RN com a BNCC, de que forma o componente Matemática pode contribuir para a formação dos 



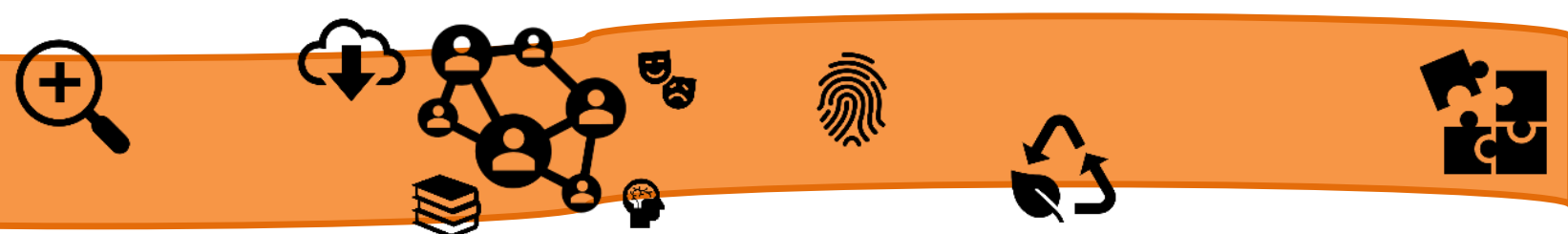

SILVA, G. B.; FELICETTI, V. L.. Habilidades e competências na prática docente: perspectivas a partir de situações-problema. Educação Por Escrito, Porto Alegre, v. 5, n. 1, p. 17-29, jan.-jun. 2014. 

acontece quando a pessoa percebe que algo precisa ser repensado a partir de uma tomada de consciência.

A Educação precisa repensar, diariamente, em sua prática pedagógica, em sua missão social e em sua organização, tudo com objetivo de oferecer uma educação especial de qualidade e inclusiva.

A escola precisa acompanhar as mudanças ocorridas na sociedade moderna e assim, se tornar realmente uma escola para todos, deixando de ser excludente e ultrapassada.

No contexto da sociedade moderna e democrática, é necessário construir uma educação que proporcione oportunidades de aprendizagens, onde os alunos com necessidades especiais construam sua aprendizagem alicerçada no respeito e estímulo. É indispensável que o professor repense e avalie seu trabalho, mesmo ciente das várias dificuldades, das inseguranças e da falta de recursos. Ele deve adotar um trabalho com princípios inclusivos para alcançar uma educação de qualidade a todos os alunos com ou sem necessidades educacionais especiais.

Falar das especificidades da educação especial na prática pedagógica, significa que, os alunos com deficiência estão sendo ensinados no mesmo contexto curricular que os demais colegas de sala de aula, destacando os materiais curriculares adequados para satisfazer as necessidades de aprendizagem de qualquer aluno.

É necessário que as escolas com educação especializada contem com materiais, tecnologia, equipamentos e professores especializados, para melhor desenvolver sua prática pedagógica para com os alunos.

A formação de práticas pedagógicas para alunos com necessidades educacionais especiais da educação Especial e Inclusiva está garantida na Declaração de Salamanca (BRASIL, 1994), na nova Constituição Federal (1988), no Estatuto da Criança e do Adolescente (1990), na atual Lei de Diretrizes e Bases da Educação (BRASIL, 1996), mas ainda assim, muita coisa precisa ser melhorada.

Posto isto, este trabalho abordará questões que possam dialogar com a temática, objetivando caminhos para a concretização do fazer pedagógico, em atendimento à inclusão, sobretudo aos alunos com necessidades educacionais especiais. 


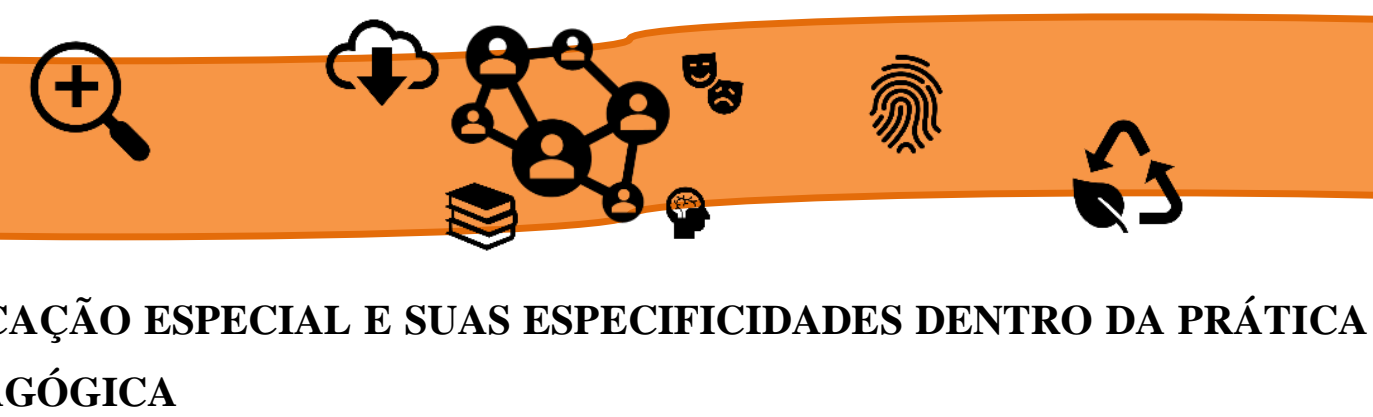

$\mathrm{Na}$ área da educação especial, o trabalho com identidade, diferença e diversidade é central para a construção de metodologias, materiais e processo de comunicação que deem conta de atender o que é comum e o que é específico entre os alunos. Neste sentido, as práticas pedagógicas devem ser voltadas para a inclusão, levando em conta todas as especificidades do aluno e sua necessidade de aprender.

Como afirma Mantoan (2004, p. 7-8): “há diferenças e há igualdades, e nem tudo deve ser igual nem tudo deve ser diferente, [...] é preciso que tenhamos o direito de ser diferente quando a igualdade nos descaracteriza e o direito de ser iguais quando a diferença nos inferioriza."

O trabalho pedagógico em sala de aula deve ter o objetivo da inclusão escolar, que requer uma reestruturação da educação, uma mudança na estrutura do ensino regular, com principal foco na escola inclusiva, se tornar um espaço democrático e competente para trabalhar com todos os alunos, sem distinção, baseando-se no princípio de que a diversidade deve não só ser aceita, como desejada. (BRASIL, 2001, p. 40).

A escola precisa ser um ambiente de busca de aprendizagem tanto para o aluno, quanto para o professor, e os professores devem estar sempre buscando aprimorar suas práticas para melhor aprendizagem dos alunos na educação especial. Este ato de busca para melhorar a prática pedagógica está centrada na diferença curricular para educação inclusiva, que procura por diferentes metodologias para atender a diversidade dos alunos com necessidades especiais.

A Escola deve sair da visão tradicional, que exclui e dificulta a aprendizagem dos alunos com necessidades educacionais especiais, tirar o foco e atenção do ensino de alunos com deficiência como limitações e dificuldades e avançar para as possibilidades de aprendizagens, através das adaptações curriculares que promova a participação de todos os alunos.

Almeida e Martins (2009, p. 17) aludem que:

Acreditamos que as boas práticas pedagógicas sejam apropriadas a todos os alunos, inclusive àqueles com necessidades educacionais especiais. (...) em alguns momentos e contextos, esses alunos podem precisar de flexibilizações mais significativas ou de atendimentos mais específicos. Um currículo, que tenha como princípio a diferença deverá considerar todas essas situações e vivências. 
Com essa flexibilização da pratica pedagógica, é possível ensinar, propor ao aluno a fazer descobertas através de uma metodologia adaptada, todo aprendizado a partir do que ele é capaz de ser, de fazer, de enfrentar, de assumir como pessoa, as possibilidades sempre à frente de qualquer dificuldade, de qualquer barreira. Assim, a Educação especial avança ainda mais para inclusão, pois independente da necessidade, o aluno tem a oportunidade de participar e aprender.

A educação especial está presente em todos os níveis, etapas e modalidades, realiza o atendimento educacional especializado, oferece os recursos e atendimentos, orienta quanto a sua utilização no processo de ensino e aprendizagem nas turmas comuns do ensino regular, mas para isso, é necessário práticas pedagógicas coerentes com a dificuldade dos alunos, fazendo com que eles sintam-se capazes de exercer sua cidadania pela aprendizagem.

Deste modo, a proposta inclusiva da Declaração de Salamanca (1994) adquiriu respaldo na $\operatorname{LDB} \mathrm{n}^{\circ}$ 9.394/96, que determina como dever do Estado: o atendimento educacional especializado aos alunos com deficiências, dando direção as práticas educacionais à inclusão dos especiais no ensino regular. E de acordo com as Diretrizes para a Educação Especial (2010), não basta o ingresso dos alunos especiais nas classes comuns do ensino regular, tem de haver outros direitos garantidos.

Uma das especificidades da educação especial é a interação do aluno com necessidade, o qual precisa interagir com o meio, não pode viver isolado, em qualquer modalidade de ensino, pois o isolamento só prejudica o avanço na aprendizagem e traz prejuízos em todas as áreas. Diante disso, é importante destacar que, a convivência com os demais alunos e professores favorece de forma significativa o desenvolvimento cognitivo, social, afetivo dos alunos, isso porque a troca de experiências e de aprendizagem ocorrem na convivência, além de ampliar sua visão de mundo, fazendo o sentir parte do contexto social.

O professor deve oferecer atividades que contribuam para a aprendizagem de conceitos, além de propor situações vivenciais que possibilitem esse aluno organizar seu pensamento. O trabalho do professor de educação especial é ajudar o aluno com deficiência(s) a atuar no ambiente escolar e também fora dele, considerando as suas 



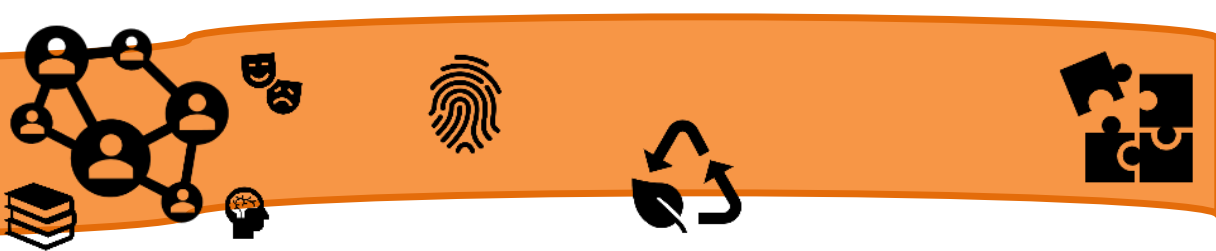

aprender. Os alunos aprendem nos seus limites e se o ensino for, de fato, de boa qualidade, o professor levará em conta esse limite e explorará convenientemente as possibilidades de cada um. Não se trata de uma aceitação passiva do desempenho escolar, mas de agirmos com realismo e coerência e admitirmos que as escolas existem para formar as novas gerações e não apenas os seus futuros membros, os mais capacitados e privilegiados (MANTOAN, 2015, p. 69).

Neste processo transformador da educação especial, a reorganização e efetivação da proposta requer a construção de novas dinâmicas educativas, uma reestruturação pedagógica para se ensinar todos os alunos, uma reconstrução além de apoios e de práticas pedagógicas específicas. Ou seja, a complexidade do processo reforça, a importância de se refletir sobre como as práticas pedagógicas contemplam as questões da diversidade e da inclusão dos alunos com necessidades educacionais especiais, e de se pensar e explicitar o funcionamento e a articulação das atividades regulares da escola com a sala de recursos multifuncionais do Atendimento Educacional Especializado.

\section{CONCLUSÃO}

Através da realização deste trabalho, foi percebido que a Educação Especial precisa passar por um período reflexão e reavaliar sobre as práticas pedagógicas utilizadas pelos professores nas escolas regulares.

Hoje, temos leis que lhe asseguram o direito de viver, estudar e participar do convívio com outras pessoas, a diferença não pode e não deve colocar a pessoa à margem da vida, sem direito de exercer sua cidadania.

Observa-se que os estudantes com deficiência são ensinados no mesmo contexto curricular que seus colegas de sala de aula, embora se saiba que, para uma efetiva aprendizagem e inclusão é necessário o uso de materiais curriculares adequados, ao nível necessário para suprir as necessidades de aprendizagem de quaisquer estudantes. Conforme os autores citados neste artigo, todo conhecimento se constrói e se transforma conforme o indivíduo vai tendo oportunidades, portanto, as práticas pedagógicas precisam ser coerentes às dificuldades apresentadas pelos alunos. 


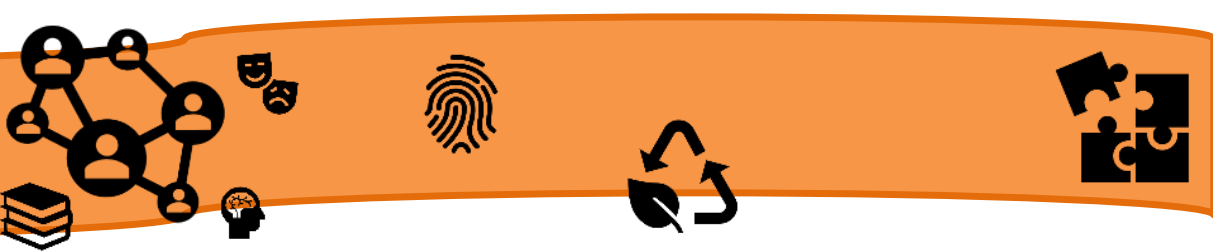

Assim, vale ressaltar que os alunos são capazes de aprender quando lhe é oferecido a melhor condição, a melhor oportunidade, para que se desenvolva em um ambiente estimulador de suas potencialidades.

De acordo com a argumentação feita até o momento sobre educação especial e inclusiva, ela é um processo que respeita e valoriza as diferenças, comprometida com ações de aprendizagem, através de estratégias metodológicas e contribui para a formação dos estudantes que, aprendem pela qualidade da educação oferecida. Enfim, a responsabilidade da escola é de planejar estratégias para atender todas as demandas, proporcionando ao aluno especial uma garantia de aprendizagem significativa.

\section{REFERÊNCIAS:}

ALMEIDA, Mariangela lima de; MARTINS, Ines de Oliveira Ramos. Prática pedagógica inclusiva: a diferença como possibilidade. Vitória, ES: GM, 2009. p. 17.

BRASIL. Congresso Nacional. Constituição de 1988: República Federativa do Brasil. Brasília: Centro Gráfico, 1988.

Congresso Nacional. Lei de Diretrizes e Bases da Educação Nacional (Lei 9.394) Brasília: Centro Gráfico, 1996.

Declaração de Salamanca e linha de ação sobre necessidades educativas especiais. Brasília: CORDE, 1994.

Diretrizes operacionais da educação especial para o atendimento educacional especial na educação básica. Ministério da Educação. Conselho Nacional de Educação. Câmara de Educação Básica. Resolução n. 4 de 13 de julho de 2010. Institui Diretrizes Curriculares Nacionais Gerais para a Educação Básica. Brasília, 2010.

Estatuto da criança e do adolescente: Lei federal $n^{\circ} 8069$, de 13 de julho de 1990. Rio de Janeiro: Imprensa Oficial, 2002. 



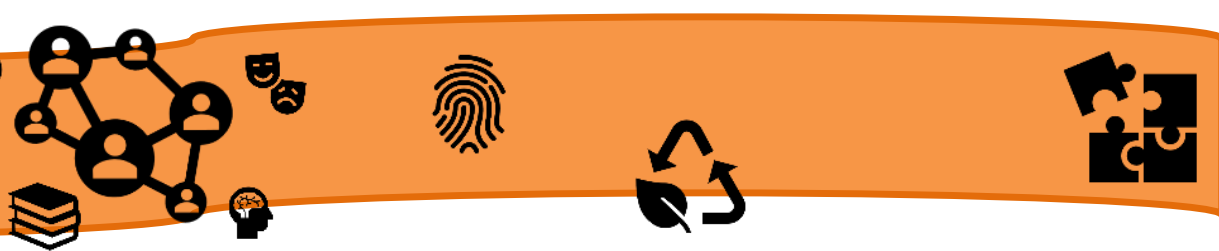

também representa para muitos estudantes o embate com muitos desafios e situações promotoras do estresse. Conforme Padovani et al (2014, p. 2), estudos "evidenciam a vulnerabilidade dos estudantes universitários e apontam para a necessidade de ampliar a discussão em torno da saúde mental dos universitários e de desenvolver programas de prevenção e intervenção".

A presente pesquisa teve por objetivo analisar os principais desafios enfrentados pelos acadêmicos do Campus da Unitins, município de Dianópolis, as consequências desses, e se houve danos à saúde.

$\mathrm{O}$ aspecto mais relevante desse estudo consiste no fato de analisar o contexto pesquisado de modo a subsidiar a implementação de ações capazes de ampliar a taxa de conclusão dos cursos, reduzir a infrequência e contribuir para o aumento da qualidade de vida do estudante universitário.

\section{REFERENCIAL TEÓRICO}

$\mathrm{O}$ acesso ao ensino superior ainda se constitui como objetivo de vida para muitos estudantes brasileiros, sobretudo para os sujeitos oriundos de famílias das classes baixa e média, as quais consideram o estudo como uma oportunidade de ascensão.

Conforme a Lei de Diretrizes e Bases da Educação Nacional, LDB 9.394/96, Art. 43, II, uma das finalidades da educação superior consiste em "formar diplomados nas diferentes áreas de conhecimento, aptos para a inserção em setores profissionais e para a participação no desenvolvimento da sociedade brasileira, e colaborar na sua formação contínua". Essa intenção estabelecida por lei, entretanto, tem sido limitada por vários fatores inerentes às práticas vivenciadas na educação superior, seja no que se refere ao acesso aos cursos, à permanência dos estudantes, à conclusão e também ao ingresso no mercado de trabalho e participação na vida nacional.

Dessa forma, orienta-se uma formação ampla na educação superior, capaz de proporcionar aos acadêmicos conhecimentos necessários à atuação nas várias dimensões da vida. As Diretrizes Curriculares Gerais para os Cursos de Graduação, corroborando com essa determinação, estabelecem como um dos princípios para os cursos de graduação:

Incentivar uma sólida formação geral, necessária para que o futuro graduado possa vir a superar os desafios de renovadas condições de exercício profissional e de produção do conhecimento, permitindo 

outras enfermidades e o ingresso em um curso de nível superior, dentre os quais Silva e Heleno (2012), Domingues et al (2008), Crepaldiet al(2016), Moretti e Hübner (2017).

Destarte, a investigação e análise no contexto pesquisado poderão indicar possíveis ações capazes de tornar o ingresso em um curso superior, o processo de adaptação à nova realidade pelos acadêmicos, a permanência na instituição e a conclusão dessa formação um processo vivenciado de forma mais equilibrada, colaborando assim para o alcance dos resultados institucionais e pessoais almejados.

\section{MATERIAIS E MÉTODOS}

O Campus da Universidade Estadual do Tocantins - UNITINS da cidade de Dianópolis começou a funcionar em agosto de $2014^{35}$ e oferece os cursos de Administração, Ciências Contábeis e Direito. Nessa Instituição pública de Ensino Superior uma das formas de acesso é o exame vestibular anual para ingresso no primeiro semestre letivo, sendo disponibilizadas o total de quarenta (40) vagas em cada um dos três cursos oferecidos.

Desde o início do seu funcionamento, o Campus vem se consolidando na oferta de Ensino Superior presencial, e atende estudantes de Dianópolis e demais municípios da região sudeste do Tocantins, e também de outros estados brasileiros.

O quadro 1 mostra a evolução do número de acadêmicos dos cursos de Administração e Ciências Contábeis:

Quadro 1 - Quantidade de Acadêmicos por período de 2014.2 a 2019.1

\begin{tabular}{|c|c|c|c|}
\hline \multicolumn{3}{|c|}{ Quantitativo de Acadêmicos } \\
\hline \multirow{2}{*}{ Ano } & \multirow{2}{*}{ Semestre } & \multicolumn{2}{c|}{ Curso } \\
\cline { 3 - 4 } & & Administração & Ciências Contábeis \\
\hline 2014 & 2014.2 & 20 & 35 \\
\hline \multirow{2}{*}{2015} & 2015.1 & 50 & 56 \\
\cline { 2 - 4 } & 2015.2 & 48 & 48 \\
\hline
\end{tabular}

\footnotetext{
${ }^{35}$ Localizado na região Sudeste do Tocantins, a $320 \mathrm{~km}$ de Palmas, o município de Dianópolis possui cerca de 19 mil habitantes. O Campus da Unitins no município teve início das atividades em agosto de 2014 com o processo de transferência voluntária dos acadêmicos da extinta Faculdade para o Desenvolvimento do Sudeste Tocantinense (FADES). Disponível em: https://www.unitins.br/nportal/campus-dianopolis Acesso em: 20 abr. 2019.
} 


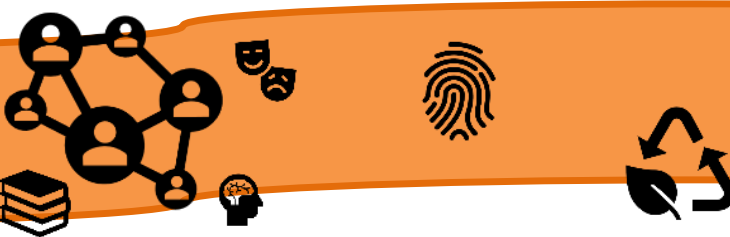

\begin{tabular}{|l|l|c|c|}
\hline \multirow{2}{*}{2016} & 2016.1 & 74 & 58 \\
\cline { 2 - 4 } & 2016.2 & 70 & 52 \\
\hline \multirow{2}{*}{2017} & 2017.1 & 96 & 63 \\
\cline { 2 - 4 } & 2017.2 & 91 & 96 \\
\hline \multirow{2}{*}{2018} & 2018.1 & 121 & 94 \\
\cline { 2 - 4 } & 2018.2 & 115 & 117 \\
\hline 2019 & 2019.1 & 114 & \\
\hline
\end{tabular}

Fonte: Secretaria Acadêmica, Campus Dianópolis (2019), elaborado pelas autoras.

Deve-se considerar que a cada ano há acadêmicos que concluem o curso, assim como acontecem também transferências internas (como a universidade possui, além da sede na capital Palmas, os Campus Araguatins, Augustinópolis e Dianópolis há transferências internas) e externas. Dessa forma, verifica-se que há uma tendência de crescimento em relação ao número de estudantes, especialmente com a consolidação dos cursos, aprovação dos egressos em exames relativos às classes profissionais e inserção no mercado de trabalho.

Esta pesquisa foi realizada com acadêmicos do terceiro período dos cursos de Administração e Ciências Contábeis do Campus Dianópolis-TO, devendo-se a opção pelos cursos pelo fato de duas das autoras já terem integrado o corpo docente dos referidos cursos.

A coleta dos dados foi realizada por meio da utilização de questionário online no Google drive, composto por onze itens, disponibilizado aos respondentes no mês de abril de 2019, o qual foi enviado a todos os acadêmicos das duas turmas, e respondido por $37 \%$ em relação ao total de estudantes (67 acadêmicos) dos dois cursos Administração e Ciências Contábeis,considerado o semestre de ingresso 2018.1.

Optou-se pelos estudantes desse período pelo fato de em 2019 já estarem cursando o terceiro período, bem como porque há uma diversidade (faixa etária, local de residência, opção pelo curso entre outros aspectos) interessante entre o universo desses estudantes, o que é demonstrado pelas respostas.

Para a análise dos resultados buscou-se tanto a análise teórica, considerando os artigos resultantes de pesquisas já realizadas em torno do tema, como a "interpretação 


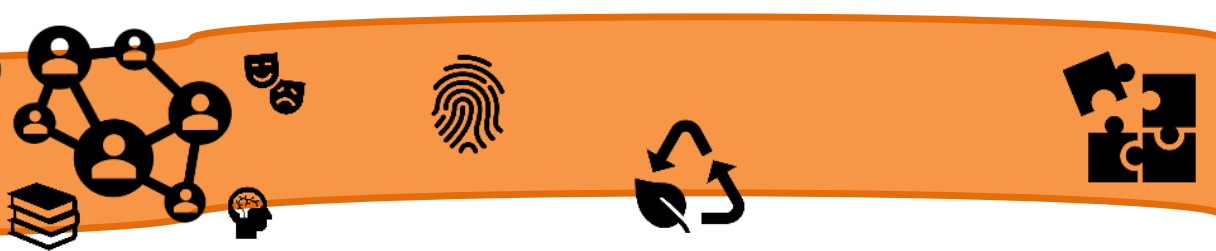

em contexto" (LUDKE, 1986, p. 18), fundamentada pela observação dos estudantes no decorrer da experiência docente.

\section{RESULTADOS}

De modo distinto ao mencionado pelos dados do INEP (2010), a faixa etária dos acadêmicos participantes da pesquisa do Campus Dianópolis se revelou jovem, sendo que do total de respondentes, $66,7 \%$ possui idade situada na faixa etária dos 18 aos 24 anos de idade. Somente 5,5\% dos acadêmicos está na faixa etária dos 39 anos de idade ou mais. Esse fato fica expresso principalmente nas turmas de primeiro período, compostas por estudantes egressos do Ensino Médio, o que possibilita o planejamento e execução de atividades inovadoras, a realização de projetos de extensão em vários campos de interesse, de modo a utilizar a criatividade e dinamismo dos estudantes mais jovens, com a capacidade de análise dos acadêmicos mais experientes.

Dentre os estudantes que responderam o instrumento, 66,7\% cursam Administração, e esse mesmo percentual reside no município Dianópolis. Os demais estudantes moram em Almas ou Porto Alegre do Tocantins, realizando o deslocamento diário de seu município até Dianópolis e retornando às 22h15, após as aulas.

Os desafios expressos pelos estudantes, além de residirem em um outro município está no fato de trabalharem, uma realidade para $83,4 \%$ dos respondentes. Desse percentual, 27,8\% já atuam na área do seu curso. Em relação aos acadêmicos que somente estudam, esses perfazem um total de $16,7 \%$.

Em relação à identificação com o curso, a metade dos respondentes afirma que o curso constituiu sua opção; $22,2 \%$ afirmaram a matrícula no curso por falta de opção e $16,7 \%$ o escolheram porque já atuam na área. Os demais estudantes conseguiram o acesso à universidade pela pontuação obtida no Exame Nacional do Ensino Médio ENEM ou resolveram concorrer a uma vaga por acreditar que o curso tem pouca concorrência.

Quando questionados sobre a principal mudança ocasionada pelo ingresso no ensino superior, $44,4 \%$ dos estudantes afirmaram a necessidade de conciliar trabalho e estudo, vindo a seguir a rotina de estudo, para $27,8 \%$ dos estudantes. Houve necessidade de mudança de cidade para $16,7 \%$ dos estudantes. 


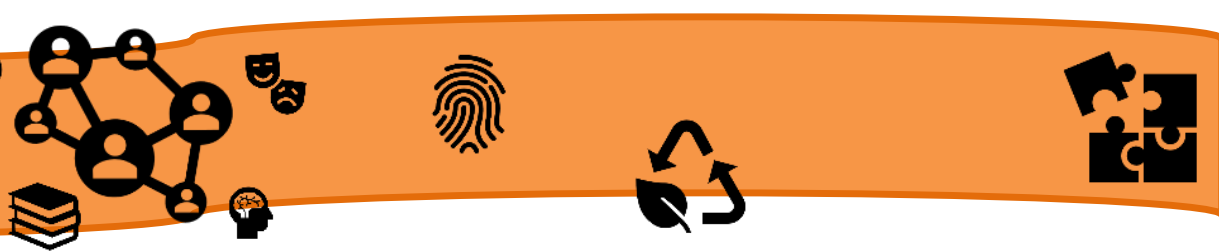

Para 66,7\% dos acadêmicos, assim como constitui a mudança mais acentuada, o maior desafio do iniciante do Ensino Superior consiste em conciliar trabalho e estudo, opção seguida pelo desemprego, que para $27,8 \%$ dificultaria a sua vida na universidade.

Quanto à satisfação com o curso, 83,3\% dos acadêmicos se consideram satisfeitos, afirmando que o curso corresponde ao que esperavam. Segundo 11,1\% estão insatisfeitos, porém, irão concluir o curso. Considerando esses dados faz-se necessário que a instituição tenha clareza quanto à expectativa dos acadêmicos, de modo a realizar práticas efetivas no sentido de cumprir a função social da educação, além do objetivo específico de qualificar mão de obra para o mercado de trabalho (CATANI, 2001). A satisfação pessoal ultrapassa esse âmbito, e a formação humana, que engloba a ética e a convivência interpessoal também devem estar inseridas nesse contexto.

O maior ganho apontado pelos estudantes com o ingresso na universidade está na atualização dos conhecimentos, conforme 55,6\%. Outro aspecto percebido como positivo é a desenvoltura na apresentação dos trabalhos, segundo 33,3\%, e a oportunidade de ter acesso a um estágio remunerado, conforme $11,1 \%$.

No que se refere a consequências negativas ocasionadas pelo ingresso na universidade, o mesmo percentual, 33,3\% aponta dois aspectos: ansiedade e nervosismo nos momentos de apresentação, e redução do tempo de descanso, em função do deslocamento diário do município onde residem até à faculdade. Em relação a questões de ansiedade e estresse, pesquisa realizada por Moretti e Hübner "revela que boa parte dos alunos participantes da pesquisa considera que a rotina universitária tem uma grande influência negativa nos níveis pessoais de estresse” (2017, p. 262).

Outra consequência apontada por $16,7 \%$ é a diminuição do convívio familiar, pelo fato de trabalhar durante o dia e estudar à noite, o que também é sentido por $11,1 \%$ cujo ingresso na universidade exigiu a mudança de cidade. Outras pesquisas também identificam a questão da redução do convívio familiar como causador de mal-estar, entre outros fatores "como a dificuldade de adaptação ao contexto universitário, relação professor aluno, distanciamento da família, sentimento de desamparo diante do desconhecido [...]" (LAMBERT; MOREIRA; CASTRO; 2018, p. 30).

Ao serem questionados sobre como solucionar a consequência negativa do ingresso na universidade, 55,6\% dos acadêmicos responderam que depende exclusivamente do estudante; $27,8 \%$ afirmam que a universidade precisa discutir essa 


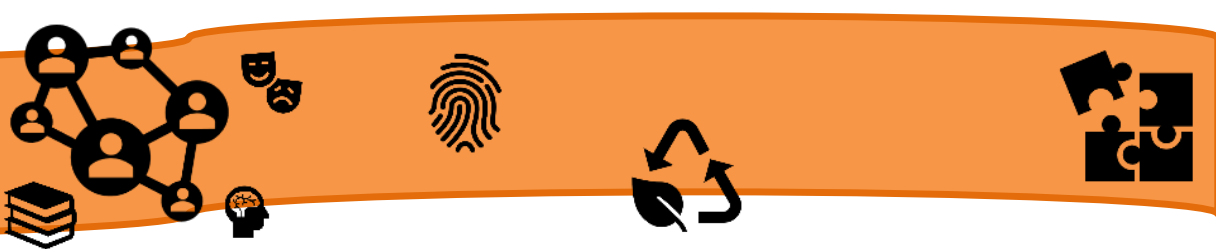

questão e contribuir para a solução; segundo $11,1 \%$ essa situação requer a intervenção do poder público.

Nesse sentido, conforme os resultados da pesquisa realizada por Moretti e Hübner, faz-se necessário intervir de fato nessa situação, uma vez que o ser humano acadêmico precisa ser atendido além da dimensão cognitiva:

\begin{abstract}
Sugere-seque os alunos sejam acompanhados ao longo do curso, tendo em vista que a Universidade não se resume apenas ao curso almejado contendo conhecimentos fragmentados por disciplinas, a Universidade deve perceber os alunos como um todo e desenvolver capacidades de busca do conhecimento com foco em qualidades e preferências, promovendo a composição de habilidades que atendam às demandas do mercado, constituindo o desenvolvimento de valores éticos e de compromisso social, incitando opiniões críticas e formando cidadãos engajados em suas sociedades (2017, p. 265).
\end{abstract}

Com o ingresso na universidade, segundo $44,4 \%$ dos estudantes houve o desenvolvimento de alguns sintomas socioemocionais dentre os quais foram citados dores de cabeça, ombros, pescoço, cansaço físico. De acordo com 16,7\% dos estudantes pesquisados houve o desenvolvimento de ansiedade, e 27,8\% dos acadêmicos responderam que nenhum sintoma foi desenvolvido.

Ao serem questionados sobre ausência das atividades acadêmicas em função desses problemas de saúde, 66,7\% responderam negativamente. Verifica-se assim que mesmo apresentando algum sintoma o estudante não costuma se ausentar das atividades acadêmicas, o que deve ocorrer, pode-se deduzir, no caso específico do Campus, em decorrência do número de faltas diárias (quatro) que teria em uma mesma disciplina, considerando que cada dia da semana é reservado às aulas de um componente da estrutura curricular.

Outro aspecto questionado foi o espaço físico, o qual, para $25 \%$ dos estudantes, considerando as salas de aula especificamente, prejudicam o desempenho acadêmico, seguidos por $12,5 \%$ que apontam o laboratório e a biblioteca como espaços prejudiciais ao desempenho acadêmico.

É importante considerar nessas respostas a ocorrência de situações como o deslocamento durante o período da aula de um espaço para outro (sala de aula para o laboratório de informática, por exemplo), uma vez que o laboratório de informática e a biblioteca do Campus, bem como o setor administrativo não funcionam no prédio 


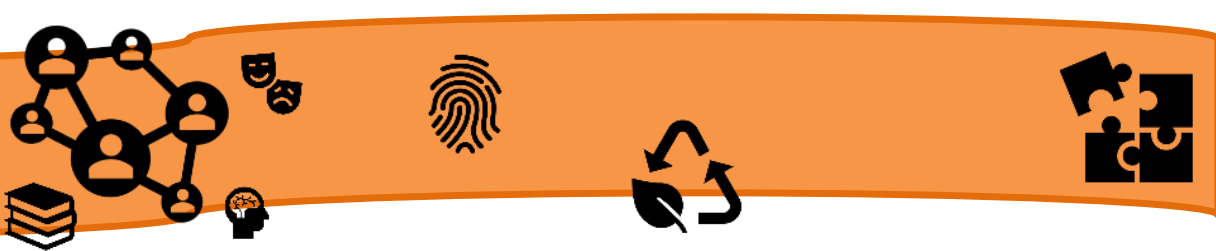

alugado onde são realizadas as aulas. Além disso, em muitas ocasiões os estudantes relatam não serem atendidos em suas necessidades de, por exemplo, realizar uma pesquisa no laboratório de informática no período noturno - por ausência de servidor e ou de conexão com a internet - ou de não ter acesso à biblioteca pelo fato de esse espaço funcionar em alguns períodos somente durante o dia.

Tais situações evidenciam a necessidade de um planejamento do funcionamento do Campus que considere o acadêmico como o foco do trabalho e da razão de ser dessa instituição de ensino, e que preze sobretudo pela qualificação dos serviços educacionais oferecidos.

\section{CONSIDERAÇÕES FINAIS}

A pesquisa demonstrou que os acadêmicos dos cursos de Administração e Ciências Contábeis do Campus Dianópolis são em sua maioria jovens e estão fazendo essa formação inicial por se identificarem com a área.

É importante essa constatação considerando que muitas vezes os profissionais afirmam estar em uma área de formação por diversos motivos distintos de sua identificação com a mesma. Nesse fato reside um aspecto muito positivo para a instituição, a qual pode contar com a colaboração desses acadêmicos em seus projetos e ações.

Um dos desafios dos estudantes reside na gestão do tempo, a fim de conciliar trabalho e estudo, sobretudo para o acadêmico iniciante, seja o egresso do Ensino Médio, ou o estudante afastado do meio acadêmico por vários anos, em função de fatores pessoais e ou profissionais e que busca a universidade com o objetivo de obter uma formação profissional capaz desqualificá-lo profissionalmente.

É importante que o Campus planeje ações, sobretudo voltadas aos acadêmicos do primeiro período, que contribuam com o estudante no sentido de promover uma organização do seu tempo, pois precisam aprender a conciliar os estudos com as demais áreas de sua vida, e o curso é composto a cada período letivo com seis disciplinas. Portanto é necessário aprender a utilizar o tempo de maneira produtiva. Nesse sentido, podem ser trabalhadas técnicas de leitura, elaboração de mapas semânticos, entre outras atividades favoráveis à compreensão dos conteúdos estudados, de modo a fazer o melhor uso do tempo disponível. 


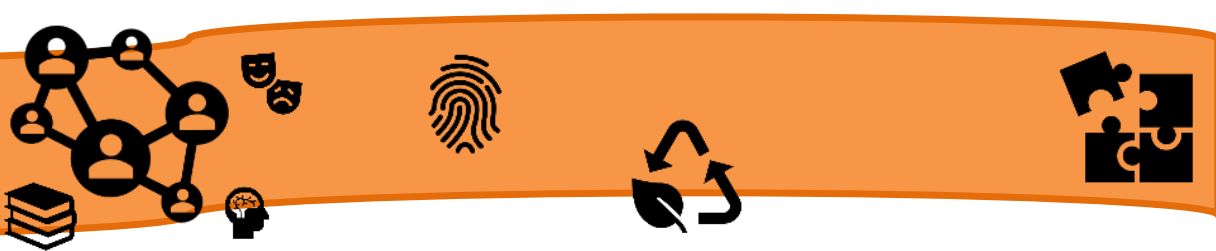

Em relação à ansiedade provocada pelos trabalhos de apresentação oral, privilegiados no contexto de avaliação da universidade, é importante que os estudantes compreendam a sua importância tanto para a academia quanto nos demais âmbitos da vida. A disponibilidade de serviço de apoio psicológico, uma vez que a instituição já conta com docente nessa disciplina seria uma alternativa para o apoio aos estudantes de um modo geral, e, especificamente àqueles que demonstrassem mais dificuldade, pois há contextos nos quais o acadêmico ainda não havia tido a experiência de se expressar oralmente em público, ocasionando situações de estresse e até bloqueio com repercussão negativa para a saúde física e mental do sujeito.

Outro aspecto que dificulta os estudos é em função de as aulas e demais atividades acontecerem em um prédio alugado, uma escola de Educação Básica, pelo fato de o Campus ainda não contar com espaço próprio. Além disso, as salas de aula funcionam em prédio diferente do setor administrativo, laboratório de informática e biblioteca.

De acordo com os acadêmicos, pelo menos até o ano 2018, a biblioteca e o laboratório de informática, não funcionavam integralmente no período noturno, no qual acontecem as aulas. Dessa forma, os estudantes ficavam sem acesso a esses recursos didáticos, uma vez não têm acesso aos mesmos no prédio alugado para realização das aulas.

Portanto, o Campus é uma instituição importante para a região, e para que o seu trabalho tenha êxito, faz-se necessário o planejamento e a execução de ações no sentido de favorecer a vida acadêmica, sobretudo para os estudantes em sua etapa inicial, a fim de que tanto os aspectos socioemocionais - por meio da como a disponibilidade de serviço de apoio e adaptação à vida universitária, o fomento ao ingresso dos estudantes em oportunidade de estágio remunerado, que possibilitaria a prática dos conhecimentos trabalhados em sala de aula e o apoio financeiro, e que ainda é um percentual pequeno conforme apontou a pesquisa -, como relativos ao espaço físico da instituição - com ações possíveis como a organização do acesso aos espaços biblioteca e laboratório de informática no período noturno - sejam aprimorados, o que certamente contribuirá tanto para a permanência, como para o bem-estar e elevação da taxa de conclusão dos cursos na instituição. 


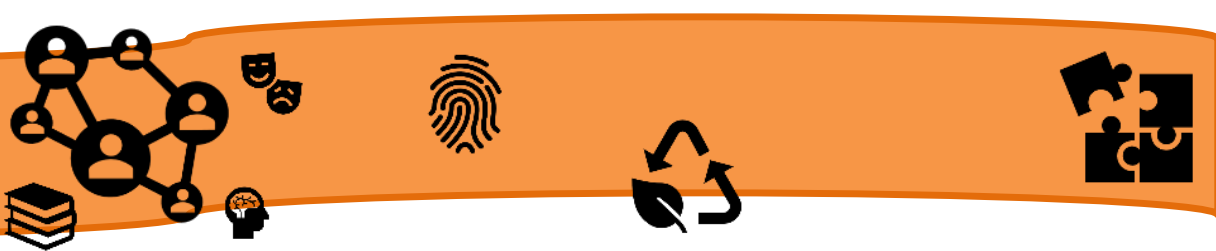

Nesse sentido, desenvolver políticas de assistência aos estudantes, visando sua integração e promoção no ambiente educativo, tais como Grupo de Apoio ao Estudante, composto por especialistas, Projetos de Pesquisa que envolvam os acadêmicos com fomento à prática de pesquisa, organização de espaços e momentos para socialização dos resultados das pesquisas e troca de experiências intra e intercampus da Universidade Estadual do Tocantins e com outras instituições de Ensino Superior, tais como seminários e ou fóruns são iniciativas imprescindíveis discussões, tanto para promoção de intercâmbio da instituição, considerando também os aspectos locais, quanto discussão das questões inerentes à vida universitária, visando à construção de uma universidade pública de qualidade, que primando pelo desenvolvimento pleno dos acadêmicos, bem como para o desenvolvimento da região.

\section{REFERÊNCIAS}

BARROS, Aparecida da Silva Xavier. Expansão Da Educação Superior No Brasil: Limites E Possibilidades. Educ. Soc., Campinas, v. 36, nº 131, p. 361390, abr.-jun., 2015.

BRASIL. Lei no 9.394/96: Lei de Diretrizes e Bases da Educação Nacional. Brasília: MEC, 1996.

CATANI, Afrânio Mendes; OLIVEIRA João Ferreira de; DOURADO, Luiz Fernandes, Educação \& Sociedade, ano XXII, n o 75, Agosto/2001.

CREPALDI, Barbara Virginia Caixeta et al. Elevada prevalência de fatores de risco para doenças crônicas entre universitários. Ciência \& Saúde, 2016; pp.135-143.

DOMINGUES, Renata de Marco. O Núcleo de Apoio ao estudante da Universidade Federal de Santa Maria como espaço de inclusão no Ensino Superior. Ponto de Vista, Florianópolis, n. 10, p. 65-78, 2008.

FRAUCHES, Celso da Costa (org.) Diretrizes Curriculares para os Cursos de Graduação. - Brasília: ABMES Editora, 2008, 702p.

LAMBERT, Aline dos Santos; MOREIRA, Larici Keli; CASTRO, Regina Celi Alvarenga de Moura. Estado da Arte sobre adoecimento do estudante universitário brasileiro. REBES - ISSN 2358-2391 - (Pombal - PB, Brasil), v.8, n.2, p.31-36, abrjun, 2018.

LUDKE, Menga; ANDRÉ, Marli E.D.A. Pesquisa em Educação: abordagens qualitativas. São Paulo: EPU, 1986. 
MORETTI, Felipe Azevedo; HÜBNER, Maria Martha Costa. O Estresse e a Máquina de moer Alunos do Ensino Superior: Vamos Repensar Nossa Política Educacional? Rev. Psicopedagogia, 2017; 258-67.

PADOVANI, Ricardo da Costa et al. Vulnerabilidade e bem-estar psicológicos do estudante universitário. Revista Brasileira de Terapias Cognitivas.2014, pp.2-10. Disponível em: http://dx.doi.org/10.5935/1808-5687.20140002. Acesso em: 20 maio 2019.

SILVA, Érika Correia; HELENO, Maria Geralda Viana. Qualidade de Vida e BemEstar Subjetivo de Estudantes Universitários. Revista Psicologia e Saúde, v. 4, n. 1, jan. - jun. 2012, pp. 69-76.

TOCANTINS. Governo do Estado do Tocantins. Perfil Socioeconômico dos Municípios. Secretaria do Planejamento e Orçamento. Diretoria de Pesquisa e Informações Econômicas Palmas - TO (2017). SEPLAN-TO, Março/2017. 



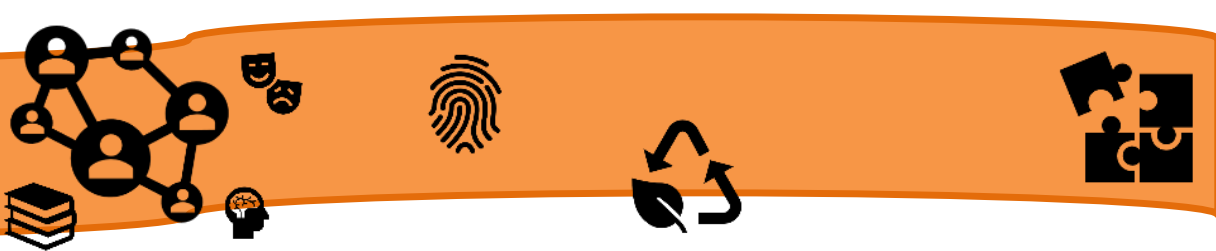

de saberes com qualquer que sejam eles, científico, popular ou empírico. Tivemos como objetivo relatar a atividade de roda de conversa ao qual proporcionou aos acadêmicos a experiência em novos movimentos de diálogo e aprendizagem, na perspectiva de troca de informações, compartilhamento de cuidados em saúde e a promoção do bem-estar.

\section{REFERENCIAL TEÓRICO}

Educar para a saúde é uma competência que profissionais da área devem adquirir ao longo de sua formação, portanto é um campo a ser trabalhado do ponto de vista da produção do conhecimento e das práticas sociais, entre todas as profissões da área da saúde (FEUERWERKER, 2007). As vivências de diferentes experiências têm revelado a necessidade de um alargamento teórico-conceitual para pensar e construir essas mudanças.

Dentre elas, as rodas de conversas que é uma estratégia política libertadora, que favorece a emancipação humana, política e social de coletivos historicamente excluídos. Por ser um método de reflexão coletiva que consiste na criação de espaços de diálogo, em que as pessoas possam se expressar e, sobretudo, escutar os outros e a si mesmos (SAMPAIO, 2014). Dialogar não é reduzir a opinião do outro e prevalecer sobre ela, não é falar para o outro, mas falar com ele (FREIRE, 1989).

Logo, a partir do nosso trabalho desejamos mostrar o quanto está equivocado tal ser, quando valoriza certo conhecimento em detrimento de outro. Para Bezerra (2013), diálogo não significa simplesmente palavras soltas ao vento, mas pronúncias que juntas fazem parte da conscientização dos homens e mulheres para a luta pela libertação. A ação promove a cidadania dos presentes, a humanização do cuidado e a singularidade do indivíduo.

Portanto, este trabalho trata-se de um relato de experiência da atividade de educação em saúde, uma roda de conversa com as adolescentes, seis acadêmicas, duas professoras e uma enfermeira.

\section{ANÁLISE}

Primeiramente foi necessária a desconstrução de um olhar de "pré-conceito" a respeito das situações de vulnerabilidade em que resultou na medida socioeducativas das meninas. A partir disso foi possível se abrir e experienciar, ficou mais fácil ouvi-las 


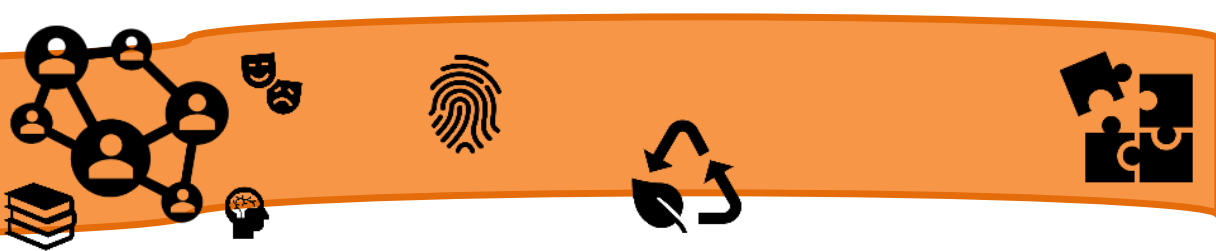

e vê-las como sujeito da troca de conhecimentos sobre o cuidado em saúde. No momento compartilhado entre todas as presentes, na identificação a partir dos relatos e na rede construída por todas, podemos observar que a valorização do indivíduo, enquanto singularidade, vai de encontro a um cuidado em saúde humanizado.

\section{RESULTADOS}

As rodas de conversa são métodos de aproximação para as trocas de saberes, cenário propício para o processo de saúde. Apesar das condições de vida das adolescentes, naquele momento, não serem as mais favoráveis, se tornaram pela vivência atual de questionamentos sobre suas ações de vida, cuidado e consequentemente saúde. A maneira a qual as meninas compreendem sobre "cuidar da saúde" é para além do processo patológico da doença como foi relatada: a prevenção de infecções sexualmente transmissíveis, todavia relacionado com os hábitos de vida, rede de apoio, saúde da mente, entre outras.

Apesar de realidades de vida tão complicadas, em comum a todas, percebemos que trouxeram para o mesmo espaço-tempo saberes diversos e singulares que, naquele momento, pelo objetivo da atividade, necessitavam ser socializados e direcionados ao cuidado em saúde.

Sendo assim, com base no objetivo inicial da ação foi possível estreitar os laços entre universidade e comunidade, saber científico e saber popular, proporcionando novos modos de aprendizagem os quais não sejam tão estratificados no interior dos currículos de formação de recursos humanos para a saúde. Não se transforma a situação de saúde do indivíduo ou da coletividade sem considerar que a construção dos sujeitos é diversa, e se dá a partir das relações intra e interpessoais, dos meios físicos, sociais e culturais.

\section{REFERÊNCIAS}

BEZERRA, A. R. R.. Contribuições da pedagogia freireana à roda de conversa sobre textos literários. In: VIII Colóquio Internacional Paulo Freire - Educação como prática da liberdade: saberes, vivências e (re) leituras em Paulo Freire, 2013, Recife. Resumos do VIII Colóquio Internacional Paulo Freire. Recife: Centro Paulo Freire Estudos e Pesquisas, 2013. 
FEUERWERKER, Laura C. M.. Educação na saúde: educação dos profissionais de saúde - um campo de saber e de práticas sociais em construção. Rev. bras. educ. med., Rio de Janeiro, v. 31, n. 1, p. 3-4, Apr. 2007.

FREIRE, P. A importância do ato de ler: em três artigos que se completam, São Paulo: Autores Associados: Cortez, 1989.

SAMPAIO, Juliana et al. Limites e potencialidades das rodas de conversa no cuidado em saúde: uma experiência com jovens no sertão pernambucano. Interface Comunicação, Saúde, Educação, [s.1.], v. 18, n. 2, p.1299-1311, dez. 2014. FapUNIFESP (SciELO). http://dx.doi.org/10.1590/1807-57622013.0264. 



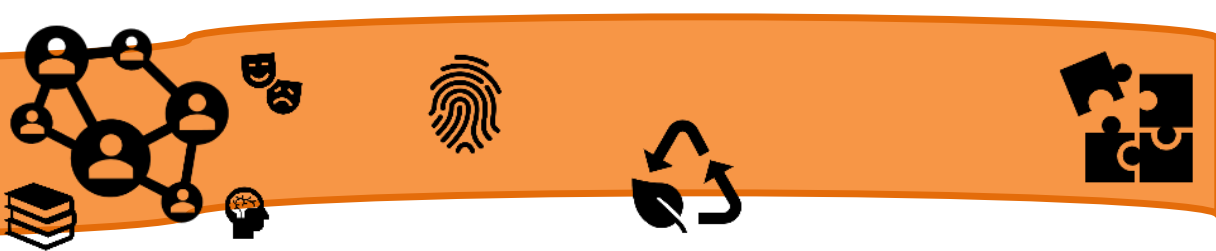

de lutas em prol de uma qualidade melhor de ensino, com resultados relevantes para a comunidade (BRASIL, 2002).

No entanto, lembramos que, mesmo com a existência da Lei, o pensamento e valores das pessoas não mudam repentinamente. E muitas vezes a inclusão não acontece como o esperado, fazendo com que a criança surda apenas preencha um espaço em sala de aula, sem ser atendido nas suas necessidades linguísticas.

Segundo Bortoleto e Rodrigues (2003), a criança com surdez tem direito garantido no ensino regular, mas, é necessário manter a sua permanência, garantindo a inclusão de forma igualitária e oportunidade de ensino de qualidade.

Dorziat (2004) considera que só há inclusão de pessoas surdas, quando a escola procura se reorganizar levando em consideração três pontos principais: a interação do uso de língua de sinais, a valorização de conteúdos escolares de libras e a formação de professores em cursos de libras. Quando o educador não tem conhecimentos de libras, dificulta o acesso ao aluno por meio da escrita, no entanto, fica impossibilitado o feedback da mesma língua entre educador e aluno.

Nesta perspectiva, surgiu o interesse pelo tema. E partimos como objetivo central de analisar como se dá o processo de integração do aluno surdo no ensino regular. Nossa problemática busca respostas para o seguinte questionamento: Será que os professores se encontram capacitados para se realizar a inclusão dessas crianças surdas em um ambiente escolar?

Destacamos como objetivos específicos: a) Analisar como se dá a inclusão dos alunos surdos em ambiente de ensino aprendizagem; b) Averiguar se professores encontram-se capacitados para trabalhar com crianças surdas em sala de aula e c) Identificar quais são as práticas e estratégias pedagógicas utilizadas pelos professores para atenderem às necessidades educacionais desses alunos.

Quanto à abordagem metodológica, tratou-se de uma pesquisa qualitativa e quantitativa, com aplicação de um questionário com professores em três unidades escolares da rede pública do Ensino Fundamental do município de Guamaré/RN.

\section{A INCLUSÃO DE SURDOS AO LONGO DA HISTÓRIA DA EDUCAÇÃO}

Antigamente famílias que tinham alguma criança com uma necessidade especial, sentiam-se envergonhadas, e na maioria das vezes essas crianças eram mantidas 
excluídas do convívio social. Atualmente esta realidade vem mudando, pessoas com alguma necessidade especial vêm ganhando seu espaço nas escolas, no mercado de trabalho e na sociedade em geral, possibilitando uma vida confortável e feliz.

Durante a década de 60 surgiram as unidades de ensino especializadas e o movimento de integração das pessoas com deficiência no meio social de forma geral (SASSAKI, 1999). Já na década de 90 a Constituição Federal Brasileira estabelece de acordo com artigo 206 e 208, a igualdade e o acesso às escolas, tornando gratuito o ensino fundamental para todos, incluindo um atendimento educacional especializado às pessoas com deficiência, preferencialmente na rede regular de ensino (BRASIL, 1996).

A foi fortalecida em 1988 quando o governo resolve modificar novamente na Constituição Federal, e cria uma lei com maior sociedade política, baseada em fundamentos de cidadania e a dignidade do ser humano; objetivando a igualdade a todos sem preconceitos e restrições de raça, sexo, cor, idade e quaisquer outras formas de discriminação (CARVALHO, 2000).

Somente a partir do século XVIII a Educação Especial passa a ganhar forças, em especial os surdos, pois, surge a criação de escolas especificamente para surdos, onde por meio de língua de sinais eles poderiam aprender e desenvolver diversos assuntos em diversas áreas. No ano de 1850, americanos passam a direcionar a Língua de Sinais, nas escolas públicas dos EUA, integrando-a a língua nata, mas sem substituições (PERLIN; STROBEL, 2006).

No Brasil, cinco anos depois e por intermédio de D. Pedro II, chega ao Brasil o professor surdo francês HernestHuet, e em 26 de Setembro de 1857, cria-se o Instituto Nacional de Surdos-Mudos, hoje, conhecido como Instituto Nacional de Educação dos Surdos-INES, fazendo uso da língua de surdos, (PERLIN; STROBEL, 2006).

Em 24 de Abril de 2002, a língua de sinais LIBRAS foi regulamentada nacionalmente pela lei 10.436 . Fica reconhecido o direito a linguagem de sinais em escola de ensino regular. Ao mesmo tempo a lei deixa clara a não substituição da mesma pela língua nata "Portuguesa". A mesma enfatiza a necessidade de se trabalhar de forma bilíngue fortalecendo aprendizagem do aluno surdo. Já que, em dezembro de 2005 por meio de um decreto, a Lei 10.436 é ratificada e torna-se obrigatório a inclusão de LIBRAS como componente curricular. 


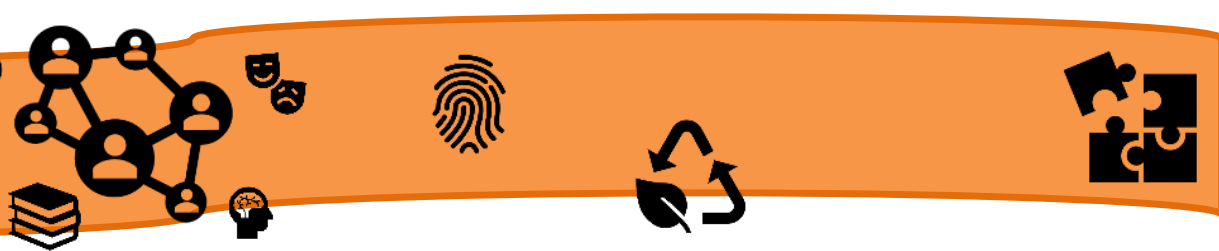

\section{PROFESSORES e feedback com a educação de ALUNOS SURDOS.}

Em meio à importância de incluir crianças com necessidades especiais nas escolas, ainda encontramos aquele educador que, gostaria que seus alunos aprendessem a partir de um único ponto, como também, de turmas homogêneas, mesmo sabendo que pessoas são diferentes uma das outras. Para Parolin (2010):

É de consenso inquestionável, que somos diferentes em nossa constituição orgânica, socioafetiva, cultural e econômica. Já sabemos que a geografia e a história de um povo, e suas interrelações, interferem no modo de viver dessas pessoas. Contudo, num paradoxo inexplicável, tentamos reunir todas essas diferenças e diferentes numa sala de aula planejada para iguais. Ainda temos a expectativa que determinada prova, ou exercício, avalie, de forma adequada, toda essa diversidade (PAROLIN, 2010, p. 21).

De acordo com a autora, turmas homogêneas não existem, pois cada ser humano tem suas particularidades, no entanto é necessário que se trabalhe essas diferenças em sala de aula, além de aceitá-las e respeitá-las, colaborando para o desenvolvimento do educando sem excluí-lo. De acordo com Libâneo (2012) é necessário que professores passem a adquirir conhecimentos acadêmicos para melhoria de suas práticas e metodologias inclusivas, segundo o autor é preciso pensar nos conteúdos que integre o todo.

\footnotetext{
A inclusão escolar caminha nas bordas tênues das relações humanas. Transita entre o sentimento profundo e verdadeiro de aceitação e de promoção de justiça social; e a tolerância, que muitas vezes esconde um sentimento de arrogância, de superioridade, ou ainda, a ilusão de que se está sendo bonzinho... Não podemos nos calar fingir que não é conosco. (PAROLIN, 2010, p. 87)
}

A autora finaliza afirmando a necessidade de adequação da escola à realidade do aluno e não o contrário como muitos ainda afirmam. Enfatiza em seu livro a necessidade de manter uma educação inclusiva na escola, fazendo com que ela realmente aconteça sem desistência. A mesma autora afirma ainda, "toda existência é digna e rara" (PAROLIN, 2010, p. 87).

\section{RESULTADOS E DISCUSSÃO}

De acordo com o que foi respondido pelos professores, ao perguntamos sobre a inclusão de alunos surdos em escola regular e as dificuldades de comunicação com os 


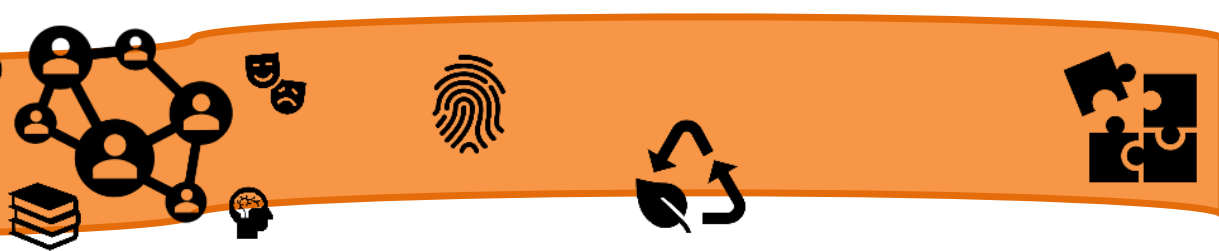

mesmo, 57\% dos professores das três instituições responderam ser a favor da inclusão dos surdos nas classes normais.

No entanto, 95\% dos entrevistados ressaltou a importância de se trabalhar a linguagem de sinais em sala de aula no intuito de facilitar a comunicação entre ambos; mas declaram a falta de recursos e despreparo das escolas e professores em receber esses alunos, que vai desde inadequação física das escolas; superlotação em salas de aula e a falta de programa de formação continuada para capacitar as equipes escolares, dificultando assim a inclusão. As falas dos educadores vão de encontro ao pensamento de Silva (2007), que afirma a falta de preparação em trabalhar com alunos com deficiência, e que são inúmeros os enfrentamentos que as mudanças provocaram (SILVA, 2007).

Em vista disso, $25 \%$ destes são totalmente a favor da presença de um intérprete na sala de aula. Já que consideram quando amparados linguisticamente os surdos podem desenvolver competências e habilidades intelectuais, no entanto, 35\% divergem dos demais colegas, afirmando que, as inclusões dos surdos se desenvolvem melhor em classes especiais devido ao uso exclusivo da língua de sinais. Já 40\% dos entrevistados embora admitam a importância das LIBRAS, não desejam de forma alguma aprendê-la.

Finalizamos nossas análises referente às respostas dadas pelos professores, observando a existência de contradições acerca do uso da língua de sinais nas classes regulares. É uma novidade que chega a intimidar educadores, mesmo sendo importantíssima na educação dos surdos em todos seus aspectos. No entanto, docentes querendo ou não, devem se adaptar à tal realidade, já que, a lei 10.436/2002 (lei da Libras) regulamentada pelo decreto 5626/2005 estabelece o uso da Libras em classes regulares, bem como a formação de profissionais para que possam garantir uma educação inclusiva em conformidade (STAIMBCK; STAIMBCK 1999).

\section{CONSIDERAÇÕES FINIS}

No decorrer deste estudo abordamos um breve relato sobre a inclusão e as leis sancionadas que deram direito à obrigatoriedade da inclusão de crianças surdas no ensino regular. Foram conhecimentos fundamentais para dar sustentabilidade às nossas análises, diante os objetivos propostos, foi possível perceber que a língua de sinais é de grande importância para o desenvolvimento cognitivo e para o processo de 


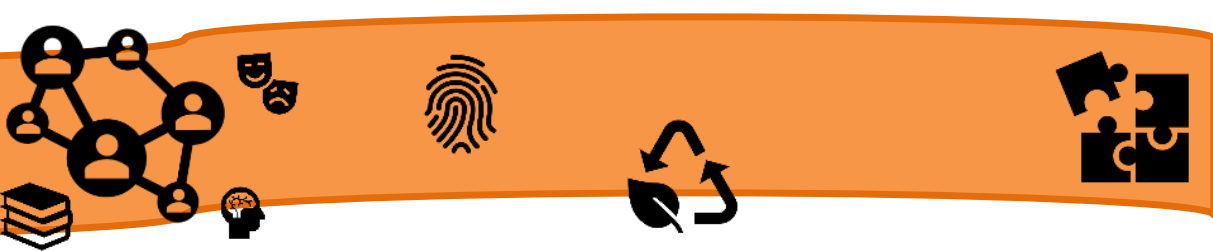

aprendizagem do sujeito surdo. No intuito de minimizar as distâncias comunicativas entre pessoas surdas e não surdas, e consequentemente, ampliaria as chances de sua inclusão no ensino regular.

No entanto, esta realidade está bem distante de acontecer em nossas escolas. Crianças são matriculadas, e profissionais totalmente despreparados na sua maioria para recepcioná-las. Na medida em que professores acham importante a inclusão de crianças surdas na escola regular e uso da linguagem de sinais nas aulas. Impõe-se em sua maioria a adequar-se a tal realidade, mostrando desinteresse em participar de cursos de capacitação em LIBRAS.

Esperamos que, futuramente, as pessoas surdas sejam realmente reconhecidas e o que está sendo ofertado a ele de acordo com a lei, seja colocado em prática de forma global e irrestrita, e não fique somente nas legislações, evitando o que chamamos de inclusão excludente.

\section{REFERÊNCIAS}

BRASIL. Lei de Diretrizes e Bases da Educação (Lei no 9394/96) http://www.planalto.gov.br. Acessado em 06/05/2018.

\section{Decreto Federal 3.298/99. 1999.}

Lei Federal 10.436 de 24 de abril de 2002. Dispõe sobre a Língua Brasileira de Sinais - Libras e dá outras providências.

Decreto 5.626 de 22 de dezembro de 2005. Regulamenta a Lei n o 10.436, de 24 de abril de 2002, que dispõe sobre a Língua Brasileira de Sinais - Libras, e o art. 18 da Lei no 10.098, de 19 de dezembro de 2000.

BORTOLETO, R. H.; RODRIGUES, O. M. P. R. A inclusão escolar enquanto prática na vida acadêmica de portadores de deficiência auditiva. Revista Espaço. Rio de Janeiro, v. 18/19, p. 45-50, 2003.

CARVALHO, Rosita Elder. A nova LDB e a Educação Especial. Rio de Janeiro: 2000.

DORZIAT, A. Educação de surdos no ensino regular: inclusão ou segregação? Revista do Centro de Educação, v. 24, p. 1-7, 2004.

PAROLIN, Isabel / Nossas crianças não podem mais esperar! (A inclusão escolar em foco). Isabel Parolin - (organizadora). São José dos Campos: Pulso Editorial, 2010. 
PERLIN, Gladis; STROBEL, Karin. Fundamentos da educação de surdos.

Florianópolis, 2006.

SASSAKI, Romeu Kazumi. Inclusão - Construindo uma sociedade para todos. Rio de Janeiro: WVA, 1999.

SILVA, Joiran M. Trajetória da Educação Especial no RN: da integração à inclusão. In: Ensaios pedagógicos: Programa Educação Inclusiva: direito à diversidade. Brasília: MEC, 2007.

STAIMBACK S.; STAIMBACK W. Inclusão: Um guia para Educadores. Porto Alegre, Artmed, 1999. 


\title{
LOS ÁRBOLES Y SUS DUEÑOS. APORTES PARA LA COMPRENSIÓN DE LOS SERVICIOS ECOSISTÉMICOS CULTURALES DE LA SELVA AMAZÓNICA COLOMBIANA. CASO DE ESTUDIO LOS SALADOS.
}

\author{
MONSALVE-CUARTAS, Ana María ${ }^{43}$
}

\section{RESUMEN:}

Para las etnias Tikuna y Uitoto, la Selva con sus lugares naturales sagrados hacen parte de la base para el pensamiento tradicional y la identidad como pueblos indígenas. La concepción y manejo de la Selva especialmente sus espacios naturales sagrados, con sus árboles y animales, vinculan al individuo y a la sociedad con el espacio, el paisaje, el cosmos, como un todo complejo, en donde es posible la coexistencia de todos de forma interdependiente en armonía. Esta percepción y forma de conocimiento ayuda al manejo y la conservación de más de 102 especies de árboles y palmas identificadas en los salados, espacios dentro de la Selva claves para la permanencia y desarrollo de numerosas especies de fauna, considerados lugares naturales sagrados para ambas etnias, y de gran importancia desde la ecología del paisaje, porque son clave en el funcionamiento del ecosistema forestal, como indicadores de su estado y dinámica natural. Se identificaron los valores culturales y espirituales de las especies de árboles más frecuentes en visitas a 11 Salados en el resguardo TICOYA sector de San Martin de Amacayacu etnia Tikuna y resguardo RITU sector los Kilómetros etnia Uitoto, en el Trapecio Amazónico Colombiano. La información necesaria se obtuvo a través de inventarios realizados al componente arbóreo y por conversaciones informales con guías y conocedores locales en los años 2016, 2017, 2018, 2019. Se concluye que ambas comunidades en estos resguardos, aún conservan principios y normas culturales que rigen sus relaciones con la naturaleza especialmente con los Salados y su flora asociada. Los Salados y muchas especies de sus árboles y palmas aún son considerados sagrados con valores culturales y espirituales. Estos valores ayudan a la conservación de especies de flora y de animales indicadoras de la salud del ecosistema forestal amazónico. Este conocimiento aporta información a los servicios ecosistemicos de tipo cultural y espiritual de la selva Amazonica Colombiana.

PALABRAS-CLAVE: Arboles sagrados, Servicios ecosistemicos culturales, Salados, etnias Tikuna y Uitoto, Trapecio amazónico colombiano.

\section{INTRODUCCION}

El Conocimiento tradicional en el manejo de los ecosistemas forestales Amazónicos por parte de sus comunidades indígenas es de gran utilidad y valor para la comprensión y conservación del Paisaje Amazónico, como instrumento de gestión de la biodiversidad, propicia el equilibrio entre el saber, el conocer, el usar y el proteger

\footnotetext{
${ }^{43}$ Ingeniera Forestal, MSc en Arquitectura del Paisaje PhD (c) Programa SUSFOR. Universidad de Lisboa- Instituto Superior de Agronomía (ISA). E-mail: Laoma468@gmail.comb
} 
(DAVIS, 2011; VON HILDEBRAND, 2012; ORTIZ FRANCISCO et all. 2015). La

Selva del Amazonas tiene una concepción diferente para sus pueblos indígenas igualmente valida a la del conocimiento científico occidental. Es una concepción sagrada donde la vivencia y las transformaciones que se ejercen sobre ella no están desligadas (objetivamente) de los procesos y vivencias internos (subjetivos) de sus comunidades indígenas. (DAVIS, 2016; ELIADE, citada por ECHEVERRY, 1998)

Según la UICN (2008); Verschuuren, B (2010) y Mallarach, J.M (2012); Una de las formas más destacadas de conservación basada en la cultura ha sido la identificación y protección de sitios naturales sagrados (SNS), que con frecuencia albergan una valiosa biodiversidad, además de proteger ecosistemas clave y paisajes patrimoniales. Las culturas indígenas, locales y tradicionales, con sus respectivas cosmovisiones, crearon áreas protegidas mucho antes del advenimiento del Parque Nacional de Yellowstone, que en la mayoría del mundo se usó como modelo para la actual legislación, política y prácticas de áreas protegidas. Los SNS son por lo tanto las áreas protegidas más antiguas del planeta.

Los SNS son aquellas áreas de agua o tierra de especial significado espiritual para los pueblos y comunidades. Para muchos pueblos indígenas, los SNS son áreas en donde la naturaleza se conecta directamente con el universo, con el cosmos, y la memoria colectiva o individual se une en estos lugares en formas significativas. Son la morada de deidades, espíritus naturales y ancestros. En el contexto amazónico se identifican en Salados, Cananguchales, Morichales, Varillales, cerros, lagos, ríos, cascadas, montañas entre otros (ver figura 1). Todos ellos son importantes referentes para la identidad cultural de un clan, una tribu o una comunidad. (ZAPATA, 2007; VON HILDREBAN ,2013; RODRIGUES, 2013; ACAIPI, 2015; SUAREZ 2018).

Los Salados para la cultura occidental, son biotopos ubicados dentro del bosque o la selva, que se caracterizan por presentar suelos con altos contenidos de minerales, en forma de sales, que son aprovechados directamente por los animales. Según fuentes secundarias se reportan más de 42 especies de animales que los visitan para suplir sus necesidades de alimentación. Los factores que influyen con mayor fuerza en la formación de los salados son el relieve, como agente acondicionador y el material parental asociado con un tipo de vegetación particular, como factor que aporta las 
características químicas y espaciales; estos sitios pueden tener entre $30 \mathrm{mt}^{2}$ y una hectárea (CABRERA, 2012; LOZANO, 2004; MOLINA et al 2018).

Son pocos los estudios que realicen una aproximación al significado cultural y espiritual de los salados y sus especies arbóreas. El objetivo de este estudio fue identificar algunos valores culturales y espirituales de las especies de árboles identificadas en 11 salados en dos resguardos de las comunidades indígenas Tikuna y Uitoto, en el Trapecio Amazónico Colombiano.

\section{METODOLOGÍA}

Se realizó una identificación y análisis a través de narrativas, mitos, textos escritos, videos y conversaciones sobre el valor cultural - espiritual de lugares naturales sagrados en la Selva Amazónica con énfasis en los Salados y sus especies arbóreas en las comunidades Tikuna y Uitoto.

La información primaria se recolecto mediante conversaciones informales, visita a los salados y reconocimiento de su flora asociada. Fue facilitada por los mayores sabedores de las comunidades Uitoto en el kilómetro 11 (resguardo RITU) y en San Martin de Amacayacu (resguardo TICOYA). Ver tabla 1

Tabla 1. Abuelos y conocedores, colaboradores en el trabajo de campo y visitas a los salados.

\begin{tabular}{|l|l|l|}
\hline \multicolumn{1}{|c|}{ Nombre } & \multicolumn{1}{|c|}{ Lugar } & \multicolumn{1}{c|}{ Ocupación } \\
\hline $\begin{array}{l}\text { Humberto Gregorio - Clan } \\
\text { Cascabel }\end{array}$ & $\begin{array}{l}\text { San Martin de } \\
\text { Amacayacu }\end{array}$ & $\begin{array}{l}\text { Cazador, conocedor de flora y fauna, guía local, } \\
\text { abuelo del concejo de sabedores de la comunidad } \\
\text { Tikuna }\end{array}$ \\
\hline $\begin{array}{l}\text { Robinson Gregorio - Clan } \\
\text { Cascabel }\end{array}$ & $\begin{array}{l}\text { San Martin de } \\
\text { Amacayacu }\end{array}$ & $\begin{array}{l}\text { Guía y conocedor de flora y fauna, pescador y guía } \\
\text { local. traductor Tikuna }\end{array}$ \\
\hline $\begin{array}{l}\text { José Gregorio - Clan } \\
\text { Cascabel }\end{array}$ & $\begin{array}{l}\text { San Martin de } \\
\text { Amacayacu }\end{array}$ & $\begin{array}{l}\text { Conocedor de flora, pescador y líder comunitario } \\
\text { Tikuna }\end{array}$ \\
\hline $\begin{array}{l}\text { Mamerto Antonio Gregorio - } \\
\text { Clan Cascabel }\end{array}$ & $\begin{array}{l}\text { San Martin de } \\
\text { Amacayacu }\end{array}$ & Curaca, líder, traductor e investigador local Tikuna \\
\hline Antonio Cayetano Sánchez. & Los Kilómetros & Malokero, abuelo conocedor Uitoto \\
\hline Nicanor Morales & Los Kilometros. & $\begin{array}{l}\text { Conocedor de flora y fauna, guía local, abuelo del } \\
\text { concejo de sabedores de la comunidad Uitoto }\end{array}$ \\
\hline Walter Torres Fariratofe & Los kilómetros & $\begin{array}{l}\text { Cazador, conocedor de flora y fauna, guía local } \\
\text { comunidad Uitoto }\end{array}$ \\
\hline Jesús Vargas & Los kilómetros & Cazador, conocedor de flora y fauna, guía local \\
\hline
\end{tabular}




\begin{tabular}{|l|l|l|}
\hline & comunidad Uitoto \\
\hline Jesus Negedeka & Los Kilómetros & $\begin{array}{l}\text { Cazador, conocedor de flora y fauna, guía local } \\
\text { comunidad Muinane }\end{array}$ \\
\hline Celimo Negedeka & Los Kilómetros & $\begin{array}{l}\text { Cazador, conocedor de flora y fauna, guía local } \\
\text { comunidad Muinane }\end{array}$ \\
\hline Ignacio Sanchez & Los kilómetros & $\begin{array}{l}\text { Estudiante de Ingeniería Forestal, Universidad } \\
\text { Distrital Francisco Jose de Caldas, investigador } \\
\text { indígena Uitoto. }\end{array}$ \\
\hline
\end{tabular}

Los Salados visitados se presentan en la Tabla 2 y Tabla 3

Tabla 2. Información base arbórea, salados resguardo TICOYA.

\begin{tabular}{|c|c|c|c|}
\hline Salados (TICOYA) & Área de muestreo en $\mathrm{mt}^{2}$ & $\begin{array}{c}\text { Numero } \\
\text { transectos } \\
(4 \times 50 \mathrm{mt})\end{array}$ & Tipo de salado \\
\hline Patura & 1000 & 5 & De talud \\
\hline Venado & 1000 & 5 & Inundable \\
\hline Huito & 600 & 3 & De talud \\
\hline Maloka & 800 & 4 & Inundable \\
\hline Piedra & 800 & 3 & De talud \\
\hline Aramacia & 600 & & 4 \\
\hline
\end{tabular}

Tabla 3. Información base arbórea, salados resguardo RITU

\begin{tabular}{|c|c|c|c|}
\hline Salado (RITU) & área de muestreo en $\mathrm{mt}^{2}$ & $\begin{array}{c}\text { Numero transectos } \\
(4 \times 50 \mathrm{mt})\end{array}$ & Tipo de salado \\
\hline Caimo & 1600 & 8 & Inundable \\
\hline Pequeño & 600 & 3 & De talud \\
\hline Kayetano & 2000 & 10 & Inundable \\
\hline Jonhy & 600 & 3 & De talud \\
\hline Patoha (casilla) & 800 & 4 & De tud \\
\hline
\end{tabular}

Se realizó un análisis estadístico descriptivo para evidenciar si existe relación entre valores tangibles e intangibles para las especies forestales identificadas en los salados visitados.

\section{El trapecio Amazónico Colombiano y los Resguardos}




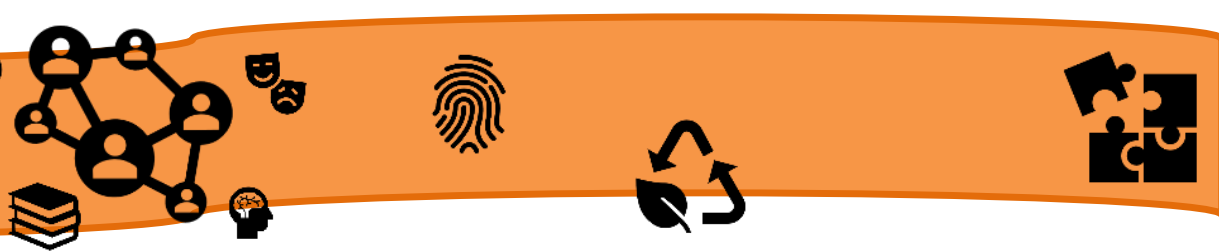

El Trapecio Amazónico ubicado en el departamento colombiano del Amazonas, se encuentra delimitado al norte por el río Putumayo, al sur por el río Amazonas, al oriente por la línea fronteriza con el Brasil desde Tarapacá hasta Leticia, y al occidente por la línea fronteriza con el Perú, desde las bocas del río Yaguas en el Putumayo hasta las bocas del río Atacuarí en el departamento del Amazonas. En la zona se destacan el río Putumayo con su principal afluente, el Cotuhé, y el río Amazonas con sus tributarios: Uassú, Atacuarí, Loretoyacu y Amacayacu. El trapecio amazónico comprende los municipios de Leticia y Puerto Nariño. Allí se localizan las comunidades indígenas Tikuna, Cocama, Yagua, Uitoto, Muinane y Tanimuca en varios resguardos (MALDONADO, 2012; JIMÉNEZ,_2013)

Los Tikuna, habitan desde la desembocadura del río Atacuari entre Colombia y Perú hasta el río Jutaí en el Brasil. En Colombia, ocupan todo el Trapecio Amazónico con más de 8000 personas. Comparten una lengua, con tres dialectos y habitan fundamentalmente la ribera del río Amazonas, donde practican la horticultura de tumba y quema, así como la pesca y la caza. Sus resguardos son: Arara, San Antonio de los Lagos, San Sebastián, El Vergel, Macedonia, Mocagua, San Martín de Amacayacu y Cothué-Putumayo, en el departamento del Amazonas (MINISTERIO DE CULTURA, 2009; LOPEZ, 2005). La comunidad de San Martin de Amacayacu está conformada en su mayoría por indígenas Tikuna (600 personas para el 2019 según el Curaca Mamerto Gregorio Velásquez)

La comunidad Uitoto (Hijos del tabaco, la coca y la yuca dulce), habita en la Amazonia colombo-peruana. Los principales asentamientos se ubican en los ríos Igaraparaná, Caraparaná, en el curso medio del río Caquetá, y en algunas localidades peruanas. En la actualidad suman unas 6000 personas en Colombia. (DANE 2005; Urbina 2010). En el trapecio amazónico los Uitotos se localizan principalmente en el resguardo RITU (Kilometro 6 y Kilometro 11 carretera Leticia -Tarapaca) resguardos Arara, San Antonio de los Lagos y San Sebastian. (AZCAITA, 2008).

\section{RESULTADOS}

\section{El valor cultural de la Selva y de sus árboles}


salados, ya que son las puertas para las fiestas de los hombres de abajo, donde los animales transformados en hombres toman masato y bailan, este lugar es una Maloka donde se reúnen todos los animales porque es donde están sus dioses, es su hogar.

En la siguientes tablas se informa sobre algunas características de los 11 salados inventariados (6 resguardo TICOYA, 5 resguardo RITU) (comunicación personal con las familias Gregorio, Morales y Negedeka, 2016, 2017, 2018). Su ubicación aproximada se muestra en la Figura 1 el perfil aproximado para 2 de ellos en la Figura 3 y Figura 4

Tabla 4. Información base arbórea salados resguardo TICOYA, sector de San Martin de Amacayacu.

\begin{tabular}{|c|c|c|c|}
\hline $\begin{array}{c}\text { Nombre del } \\
\text { salado }\end{array}$ & $\begin{array}{c}\text { Número } \\
\text { de } \\
\text { árboles }\end{array}$ & $\begin{array}{c}\text { Número de } \\
\text { especies }\end{array}$ & $\begin{array}{c}\text { Número de } \\
\text { familias }\end{array}$ \\
\hline Patura & 63 & 31 & 18 \\
\hline Venado & 75 & 37 & 21 \\
\hline Huito & 41 & 22 & 17 \\
\hline Maloka & 57 & 29 & 16 \\
\hline Piedra & 46 & 28 & 16 \\
\hline Aramacia & 54 & 26 & 17 \\
\hline
\end{tabular}

Tabla 5. Información base arbórea, Salados resguardo RITU, sector los Kilometros.

\begin{tabular}{|c|c|c|c|}
\hline $\begin{array}{c}\text { Nombre del } \\
\text { Salado }\end{array}$ & $\begin{array}{c}\text { Número de } \\
\text { árboles }\end{array}$ & $\begin{array}{c}\text { Número } \\
\text { de } \\
\text { especies }\end{array}$ & $\begin{array}{c}\text { Número } \\
\text { de } \\
\text { familias }\end{array}$ \\
\hline Kaimo & 120 & 40 & 23 \\
\hline Pequeño & 52 & 21 & 12 \\
\hline Kayetano & 176 & 68 & 28 \\
\hline Jonhy & 29 & 18 & 11 \\
\hline Patoha & 37 & 18 & 12 \\
\hline
\end{tabular}

Se identificaron más de 102 especies de árboles y palmas, con algunas especies como la chambira- Astrocaryum chambira, la pona barrigona- Iriartea deltoidea-, la ponilla- Socratea exorrhiza, Aguaje o Moriche -Mauritia flexuosa-, y arboles como 
Yanchama o Oje-Ficus maxima sp y Renaco Ficus schultesii, con valor cultural espiritual para ambas etnias.
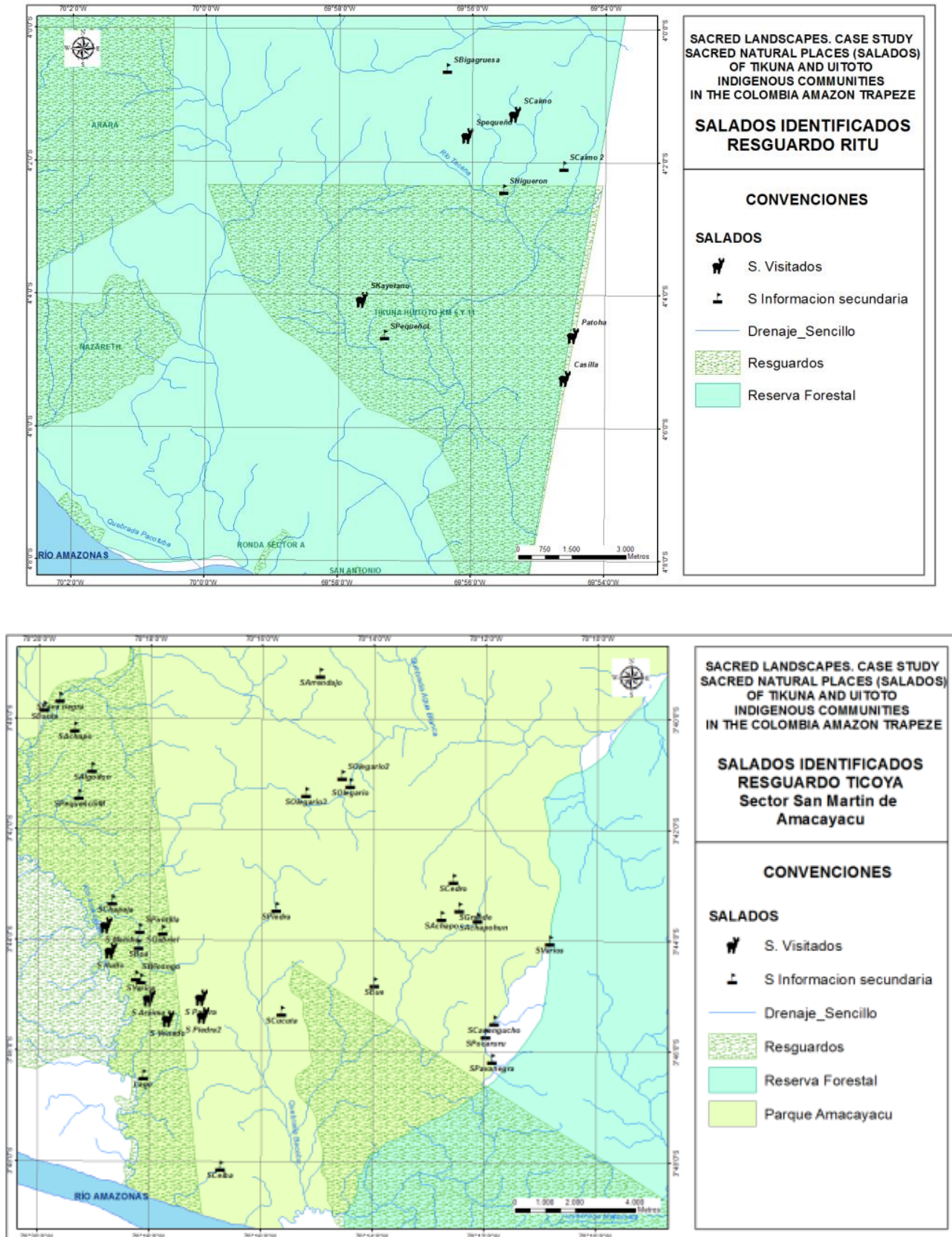

Figura 1. Superior. Ubicación de algunos Salados en RITU inferior. Ubicación de algunos Salados en San Martin de Amacayacu (TICOYA). 

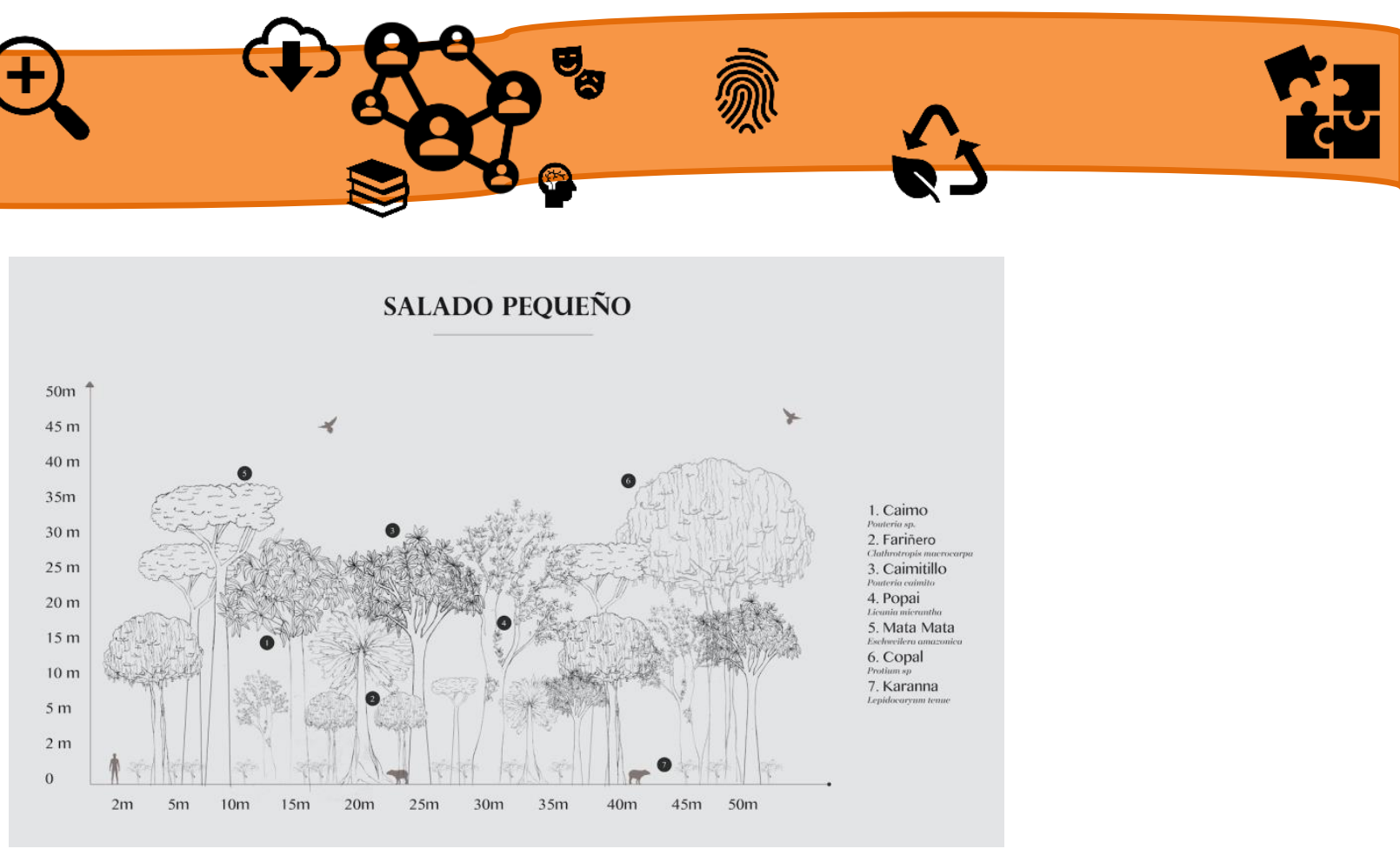

Figura 2. Composición arbórea en un transecto del salado Pequeño en la comunidad Uitoto sector los Kilometros.

\section{SALADO MALOKA}

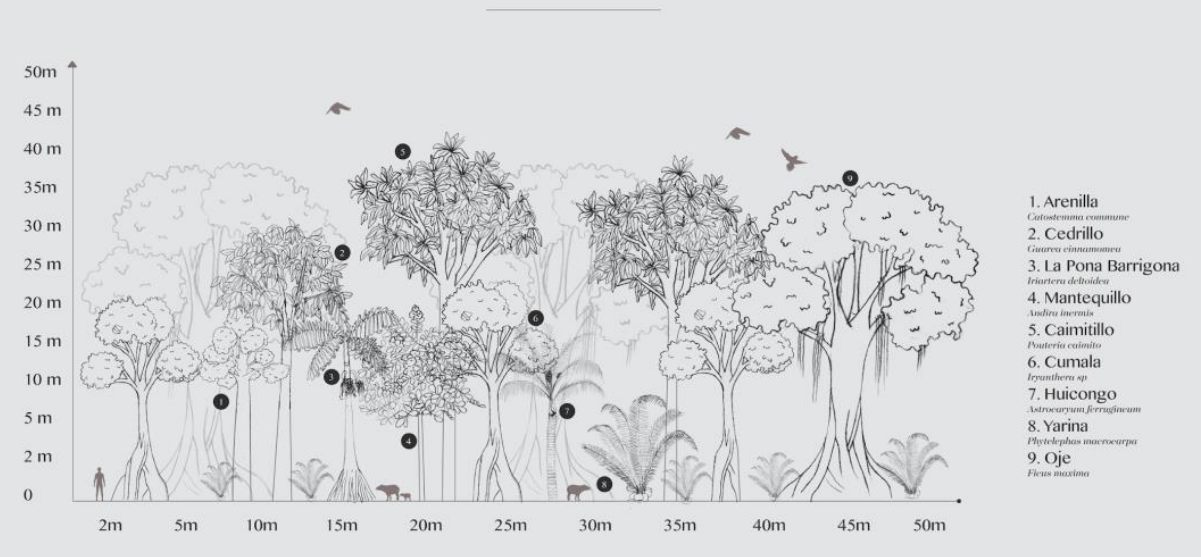

Figura 4. Composición arbórea en un transecto del salado Maloka en la comunidad Tikuna Sector San Martin de Amacayacu.

\section{Arboles sagrados}

Para los Tikunas y Uitotos, en la selva existen árboles que poseen un valor tangible ya sea por su valiosa madera, medicina, alimento y/o un valor intangible por tener poderes que ayudan a los chamanes en su labor y por ser referentes ancestrales.

En los inventarios realizados en los salados, se identificaron un total de 102 especies de árboles y de palmas, reunidas en 90 géneros y 35 familias. El 90\% de estas especies tiene un valor cultural y/o espiritual.

Con el uso del programa de estadística SPSS se realizó un análisis para reconocer si hay relación entre los valores asociados a los usos (Usos: hojas; artesanías (tambores, utensilios); medicina; madera (leña, construcción); frutos y semillas; corteza 
y fibras; resinas y cauchos, colorantes y tintas; con dueños espirituales) identificados en ambas comunidades. Se usaron 102 unidades taxonómicas a nivel de género y especie cuando se identificó plenamente al árbol.

Se usó la herramienta de conglomerados jerárquicos con matriz de distancias, para analizar si las variables tienen relaciones significativas entre ellas por medio del método de vinculación inter grupos - Jaccard (Grafica 1). Como se puede evidenciar, los usos otorgados a las especies identificadas en el conjunto de datos se pueden agrupar en 3 grupos con relaciones significativas entre sí.

El primer grupo según la Grafica 1 son los usos por madera para la construcción y leña, asociada con uso por frutos, semillas y artesanías (tambores, juguetes, utensilios para la cocina). Las familias más representativas en este grupo por mayor número de especies son: Fabaceae, Meliaceae, Myristicaceae, Apocynaceae Aracaceae, Caryocaraceae. Las especies y géneros asociados en la tabla 6.

Grafica 1. Dendrograma resultado del análisis entre variables tipo uso.

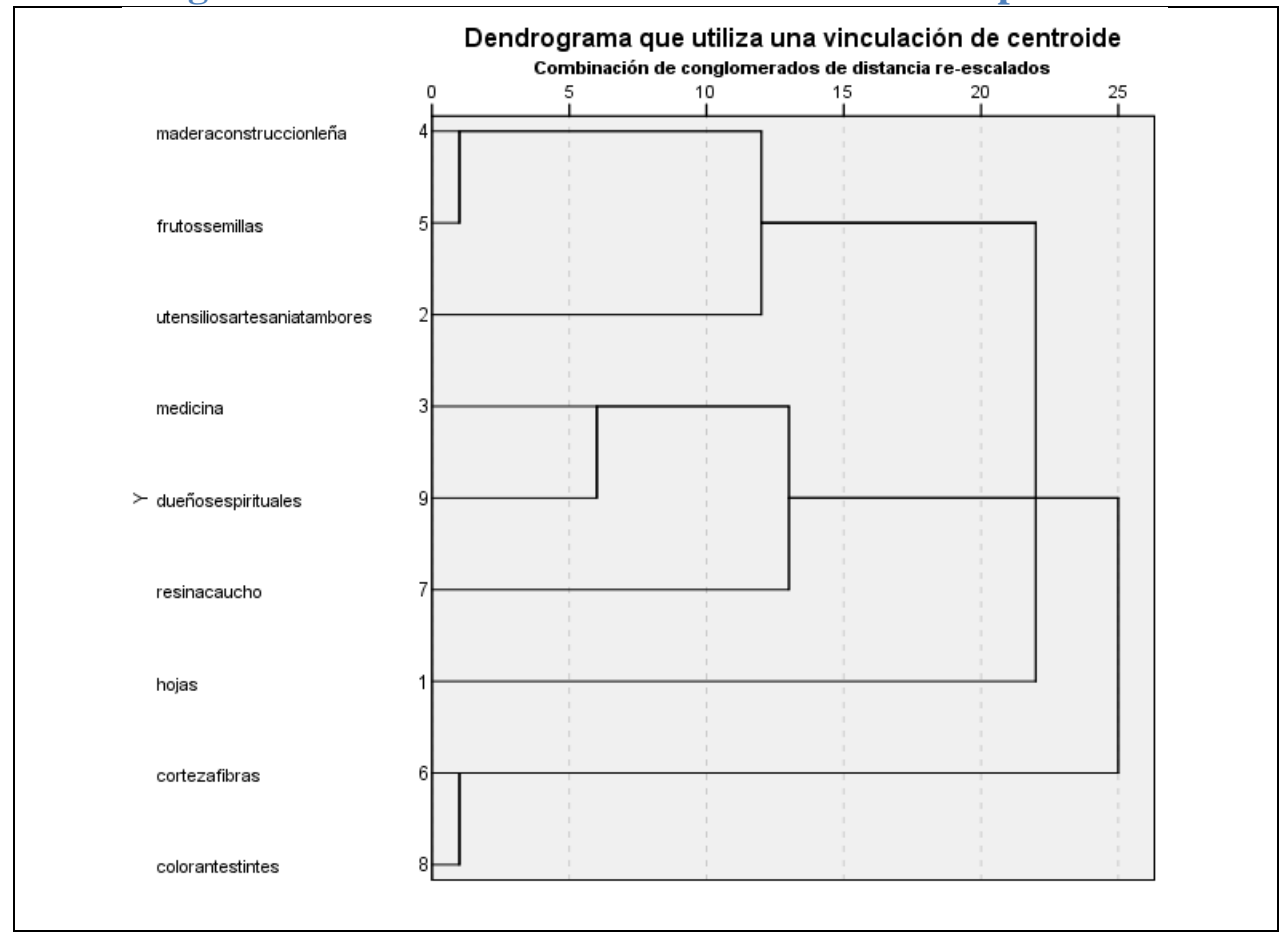

Tabla 6. Familias y especies asociadas con mayor uso por madera, frutos, semillas y artesanías.

\begin{tabular}{|l|l|}
\hline Familia & $\begin{array}{l}\text { Nombre } \\
\text { científico/genero }\end{array}$ \\
\hline
\end{tabular}




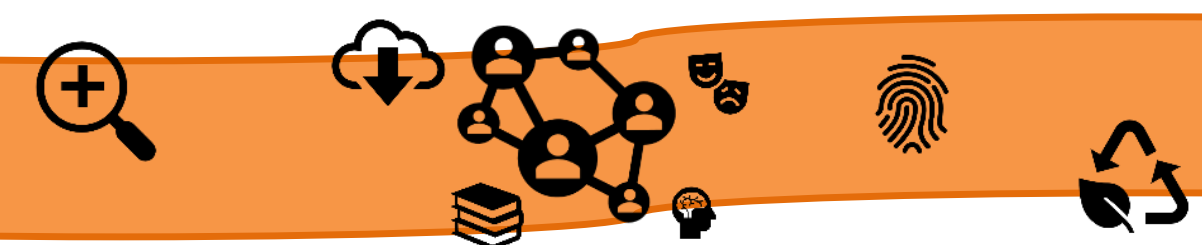

\begin{tabular}{|c|c|}
\hline Anacardiaceae & Anacardium excelsum \\
\hline Apocynaceae & Couma macrocarpa \\
\hline Apocynaceae & Lacmellea arborescens \\
\hline Aracaceae & Euterpe precatoria \\
\hline Aracaceae & Socratea exorrhiza \\
\hline Caryocaraceae & Caryocar glabrum \\
\hline Caryocaraceae & Caryocar glacile \\
\hline Combretaceae & Terminalia dichotoma \\
\hline Euphorbiaceae & Caryodendron $s p$ \\
\hline Fabaceae & Hymeneae sp \\
\hline Fabaceae & Parkia $s p$ \\
\hline Fabaceae & Parkia igneiflora \\
\hline Lecythidaceae & Cariniana decandra \\
\hline Meliaceae & Guarea cinnamomea \\
\hline Meliaceae & Carapa guianensis \\
\hline Moraceae & Naucleopsis ulei \\
\hline Myristicaceae & Virola $s p$ \\
\hline Myristicaceae & Iryanthera $s p$ \\
\hline Olacaceae & Minquartia guianensis \\
\hline Rubiaceae & Posoqueria $s p$ \\
\hline Sapotaceae & Manilkara bidentata \\
\hline Sapotaceae & Simarouba amara \\
\hline
\end{tabular}

El segundo grupo son los usos por medicina, resinas y cauchos asociados a las especies con dueños espirituales. Las familias más representativas en este grupo son Euphorbiaceae, Apocynaceae y Fabaceae. Las especies y géneros frecuentes se presentan en la siguiente Tabla 7.

Tabla 7. Familias y especies asociadas con mayor uso por medicina, resina, cauchos y con dueños espirituales.

\begin{tabular}{|l|l|}
\hline Familia & Nombre científico/ Genero \\
\hline Apocynaceae & Aspidosperma \\
\hline
\end{tabular}


60 años un acopio de conocimiento filosófico, ecológico y espiritual que permite manejar y conservar los sistemas de flora asociados a los salados.

Es prioritario garantizar que este conocimiento sea transmitido en las generaciones más jóvenes, para perpetuar y mejorar el estado de los salados como lugares clave para el funcionamiento del ecosistema forestal amazónico.

La estructura de la Selva en los salados identificados, conserva una riqueza y composición gracias a la gestión espiritual en el manejo y uso que le dan las comunidades Tikuna y Uitoto a estos espacios. Cerca del 90\% de las especies arbóreas y de palmas allí identificadas tienen un valor cultural y espiritual. Las familias más representativas son Fabaceae, Arecaceae, Lecythidaceae. Los géneros con mayor número de usos reportados son (tabla 9):

Tabla 9. Familias y géneros asociados con mayor número de usos.

\begin{tabular}{|l|l|l|}
\hline familia & Nombre científico & Nombre local \\
\hline Meliaceae & Carapa guianensis & Andiroba \\
\hline Lecythidaceae & Cariniana decandra & Abarco \\
\hline Apocynaceae & Couma macrocarpa & Surba, juan soco \\
\hline Fabaceae & Hymeneae sp & Poru, macuri, mari mari \\
\hline Fabaceae & Alexa sp & Alcanfor \\
\hline Apocynaceae & $\begin{array}{l}\text { Aspidosperma } \\
\text { myristicifolium }\end{array}$ & Remocaspi, costillo macho \\
\hline Lecythidaceae & Eschweilera $s p$ & Mata mata (blanco, amarillo, rojo, negro) \\
\hline
\end{tabular}

Los salados, conforman un tejido de puntos en el territorio dentro y fuera de los resguardos con valor cultural y ecológico que funciona como un tejido social para las comunidades Tikuna y Huitoto.

Esta red ayuda a conservar la biodiversidad y debe ser identificada y visibilizada en los planes de manejo forestal, planes de ordenamiento territorial y planes de desarrollo local en la región amazonica.

Los servicios ecosistémicos de tipo cultural- espiritual de especies de árboles y sitios naturales sagrados según el conocimiento indígena, indican nuevos caminos para el manejo de los ecosistemas amazónicos. La protección de estos sitios naturales sagrados requiere además de las actuaciones de las comunidades indígenas para la 


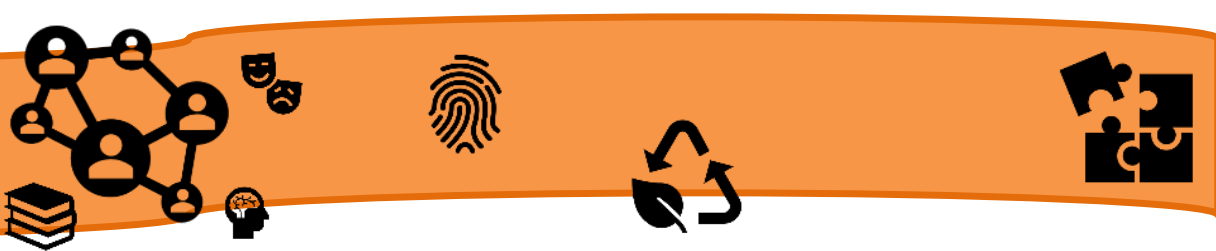

conservación y el mantenimiento de los ecosistemas asociados, una legislación que los visibilice y blinde de intereses comerciales, mineros y turísticos, del desarrollo de conflictos sociales y de las acciones económicas y extractivistas del actual modelo de desarrollo occidental que merodean en estas regiones.

Se requiere elaborar una cartografía actualizada y precisa de los sistemas de Sitios Naturales Sagrados, como herramienta de manejo del Paisaje y defensa de los derechos territoriales y culturales, así como salvaguarda del patrimonio biocultural (tangible e intangible) de la Selva Amazonica.

\section{OTRAS INFORMACIONES}

This work is funded by FEDER funds through the Operational Programme for Competitiveness Factors - COMPETE and by National Funds through FCT Foundation for Science and Technology under the PD/BD/128264/2016 and POCI-010145-FEDER-006821"

Ignacio Sánchez, estudiante de Ingeniería Forestal, Universidad Distrital Francisco Jose de Caldas, investigador indígena Uitoto. Comunidad los kilometros resguardos RITU Amazonas - Colombia. sancheznach@gmail.com.

Antonio Gregorio, investigador indígena Tikuna. Comunidad San Martin de Amacayacu resguardos TICOYA Amazonas-Colombia.

\section{BIBLIOGRAFIA}

ACITAM. Plan de Vida de la Asociación de Cabildos Indígenas del Trapecio Amazónico. Puerto Nariño- Amazonas. 2008.

\section{ACAIPI. (2015). El Territorio de los Jaguares del Yurupari Hee Yaia Godo}

\section{Bakary.}

Bogota:GAIA.

https://www.gaiaamazonas.org/uploads/uploads/books/pdf/El_Territorio_de_los_Jagua res_de_Yurupar\%C3\%AD_Gaia_Amazonas_ACAIPI_2012_.pdf.

ACAIPI. Los conocimientos tradicionales de los chamanes jaguares de... (Colombia) Lista representativa - 2011. fuente http://www.unesco.org/culture/ich/es/RL/los-conocimientos-tradicionales-de-loschamanes-jaguares-de-yurupari-00574. https://www.youtube.com/watch?v=Gq4dgKmSms\&index $=16 \&$ list=PLltItL--5Gu5gmuy3Px4hcxw0-WkN39bB. Consultado febrero 2020 
ALVAREZ, Esteban. Cuánto Vale la Naturaleza, (Bosques, biodiversidad y servicios eco sistémicos) Revista Propiedad Publica (apropiación social del conocimiento) 21 pag. 2013

ARANGO \& SANCHEZ. Los pueblos indígenas de Colombia en el umbral del nuevo milenio: población, cultura y territorio: bases para el fortalecimiento social y económico de los pueblos indígenas. Departamento Nacional de Planeación. Dirección de desarrollo sostenible. Bogotá. Colombia. 2004

ACOSTA, L. E., \& Mendoza, D. El conocimiento tradicional: Clave en la construcción del desarrollo sostenible en la Amazonía Colombiana. Colombia Amazónica, 101-118 2006.

ASOAINTAM. Plan de Vida de los Cabildos Uitoto, Tikuna, Bora, Cocama e Inga de la Asociación de Autoridades Tradicionales de Tarapaca- Amazonas. TarapacaAmazonas. 2007

ATICOYA. Actualización del Plan de vida de los Pueblos Tikuna Cocama Yagua. Puerto Nariño. Amazonas.

AZCAITA. Plan de vida de los pueblos Tikuna, Uitoto, Cocama y Yagua. 2008.

CABRERA, Juan. "Natural licks and people: towards an understanding of the ecological and social dimensions of licks in the Colombian Amazon". Tesis Doctoral, School of Antrhopology and Conservation. Canterbury, University of Kent. 2012

DAVIS, Wade. Los guardianes de la sabiduría ancestral (su importancia en el mundo moderno). Silaba edit. Medellín, 220pag. 2016

DANE. Departamento Administrativo Nacional de Estadística. Colombia: una Nación multicultural. Su diversidad étnica. Bogotá: DANE. Dirección de Censos y Demografía 2007. Fuente

http://www.dane.gov.co/files/censo2005/etnia/sys/colombia_nacion.pdf consultado diciembre 2018

ECHEVERRY, J. Alvaro. Territorio como cuerpo y territorio como naturaleza: Dialogo intercultural?.En Surralles, A.y Garcia Hierro, P. (dir), Tierra adentro, Territorio indígena y percepción el entorno (p. 259-275) Copenhague: Grupo internacional de Trabajo sobre Asuntos Indigenas. ISBN 87-90730-80-1. 2004. Fuente http://www.ecominga.uqam.ca/PDF/BIBLIOGRAPHIE/GUIDE_LECTURE_6/5/1.Alv aro_Echeverri.pdf consultado abril 2019

ECHEVERRY,J. Alvaro \& Jitdutjaaño Oscar Roman. la sal de monte: un ensayo de halofitogenografía" Uitoto .1998.Fuente http://www.bdigital.unal.edu.co/3740/2882/lasaldemonte.pdf. Consultado enero 2019

FRANKY Calvo Carlos Eduardo. Territorio y Territorialidad Indígena. Un estudio de caso entre los Tanimuca y el bajo Apaporis (Amazonia Colombiana). tesis Magister 
en Estudio Amazonicos. Línea de investigación en Estudios Regionales, Universidad Nacional de Colombia, sede Leticia. Leticia.2004

GREGORIO Vasquez Jose \& Verschoor Gerard. In defense of ourselves. Towards the perfection in the relationships between the Tikuna world and the western world. Tropembos Fundation. 2011.

GOULARD. Tikuna en Guía etnográfica de la Alta Amazonia. Fernando Santos y Frederica Barclay Editores. 311-383 pag. 1994. Fuente http://www.flacsoandes.edu.ec/libros/digital/50071.pdf. Consultado 04 abril 2019

HANS ter Steege et al. Hyperdominance in the Amazonian Tree Flora. Sciencie Vol 342 no. 6156 DOI. 2013

http://www.sciencemag.org/content/342/6156/1243092.abstract consultado enero 2018

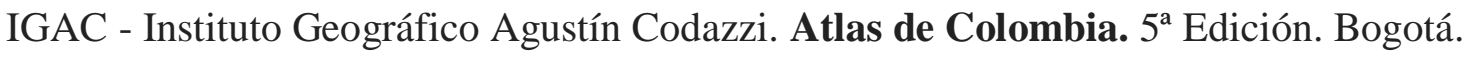
2002

IZQUIERDO, Jacobo Elí (Comp.) Pueblos indígenas de Colombia. 2010. Fuente http://www.scribd.com/doc/26664597/Pueblos-indigenas-de-Colombia. Consultado Marzo de 2018

JIMENEZ Rojas, Eliana Maria. Carbon allocation in north-western Amazon forests (Colombia). Tesis Doctoral, E.T.S.I. Montes (UPM). 2013

KUYOTECA Angel Jifikomui, “GA+RIYAROK+". Mitología Uitota, contada por un Aron+ , "gente de avispa". Medellin , Editorial Lealon. 1997

LOZANO Barrero Carolina Maria. Efectos de la Acción Humana sobre la frecuencia de uso de los Salados por las Dantas (Tapirus terrestres) en el sureste del Trapecio Amazonico Colombiano. Universidad Nacional de Colombia sede Leticia. 2004

LOPEZ Garces Claudia . Tikunas brasileros, colombianos y peruanos Etnicidad y nacionalidad en la región de fronteras del alto Amazonas /Solimoes. Tesis de Doctorado ante Centro de Pesquisa e Pos-graduacao sobre America Latina y Caribe CEPPAC de la Universidad de Brasilia. 2005. Fuente

http://www.scielo.org.co/pdf/rcan/v38/v38a04.pdf . Consultado Julio 2018

MALDONADO Angela Maria. "Hunting by Tikunas in the Southern Colombian Amazon. Assessing the impact of subsistence hunting by Tikunas on game species in Amacayacu National Park, Colombian Amazon ”. Tesis doctorado LAP Lambert Academic Publishing GmbH \& Co. KG. Saarbrücken, Germany.2012

MALLARACH Josep Maria. El Patrimonio inmaterial: valores culturales y espirituales. Manual para su incorporación en las áreas protegidas. Europarc -España. Madrid: Ed Fundación Fernando Gonzales Bernáldez. 2012 
UICN. Wild, R. y McLeod, C. (Editores). Sitios Sagrados Naturales: Directrices para Administradores de Áreas Protegidas, Gland, Suiza: UICN. 2008

Verschuuren, B., Wild, R., McNeely, J. A., \& Oviedo, G. . Sacred Natural Sites.

Conserving Nature \& Culture. London: IUCN.2010

Ver tambien de lugares sagrados. http://www.sacredland.org/media/Sacred-Sites-an-

Overview.pdf. http://www.sacredland.org/PDFs/SNS_Guidelines.pdf.

https://cmsdata.iucn.org/downloads/iucn_sitios_naturales_sagrados.pdf

URBINA Rangel. Fernando Las palabras del origen, breve compendio de la mitología de los Uitotos Ministerio de Cultura (Biblioteca básica de los Pueblos Indigenas de Colombia) Colombia. 2010. Fuente

http://www.banrepcultural.org/sites/default/files/89037/04-Las-palabras-del-origen-

Breve-compendio-de-la-mitologia.pdf. Consultado enero 2018

VON Hildebrand Martin. Desafíos y oportunidades de la cooperación amazónica a través de la OTCA. Panel 1 la amazonia en el escenario internacional. Cancilleria Colombia 2013 fuente

https://www.youtube.com/watch?v=aH43is6PQWU\&index=94\&list=PLltItL-5Gu5gmuy3Px4hcxw0-WkN39bB

VON Hildebrand Martin \& Brackelaire Vincent. Guardianes de la Selva (Gobernabilidad y Autonomia en la Amazonia Colombiana). Fundacion Gaia Amazonas. Bogota- Colombia 2012. ISBN 978-958-97730-6-2.

https://issuu.com/studiovisual_sas/docs/guardianes_de_la_selva 


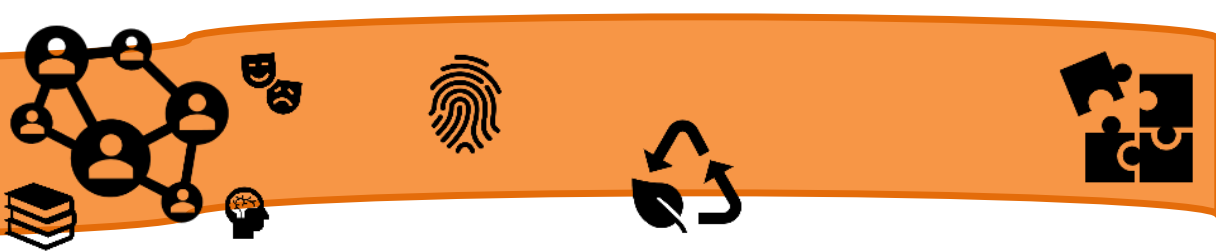

para o desenvolvimento da criança, o brincar na Educação Infantil de acordo com a Base Nacional Comum Curricular - BNCC. É garantido o direito de brincar e as brincadeiras são essenciais e devem estar presentes intensamente na rotina da criança, trata-se de iniciativas que o adulto deve acolher e enriquecer, porém deve ser planejadas com antecedência e diversificadas.

Nessa perspectiva o ato de brincar, faz a criança pensar, expressar emoções, desejos, pensamentos, necessidades e sentimentos, além disso, contribui no processo de ensino e aprendizagem, pois a brincadeira promove essa interação, estimula a criação da criança, faz com que recrie ideias e fantasias. Nesse contexto, a criança ganha autonomia sob seus movimentos, pensamentos e imaginação.

A relevância desse estudo, destaca-se a possibilidade de se conhecer teorias que apontam as atividades lúdicas como instrumento de aprendizagem capazes de contribuir significativamente com o desenvolvimento mental e humano da criança. A partir dessa compreensão, o professor poderá se empenhar mais, melhorar sua prática e realizar atividades dinâmicas no espaço escolar promovendo aprendizagem de forma divertida.

Este trabalho tem como objetivo apresentar a importância do brincar e as contribuições das atividades lúdicas no desenvolvimento da criança na escola.

A metodologia usada foi através de um estudo bibliográfico para aprofundamento dos estudos sobre o uso do brincar como estratégia de ensino e aprendizagem e a importância do lúdico no desenvolvimento e aprendizagem.

\section{A EDUCAÇÃO E O USO DO BRINCAR COMO ESTRATÉGIA DE ENSINO E APRENDIZAGEM}

Durante vários anos a educação da criança era uma responsabilidade das famílias e do grupo social a qual elas pertenciam, junto aos adultos e outras crianças com os quais conviviam e que as mesmas aprendiam a se tornar membro deste grupo, a participar das tradições importantes e dominar os conhecimentos que eram necessários para a sua sobrevivência e para enfrentar as exigências da vida adulta era uma obrigação (HAETINGER, 2004).

Por um longo período na história, a Educação Infantil não era vista como algo importante, era apenas responsabilidade dos pais e da comunidade onde vivia, esse fato 
veio a se modificar recentemente, sendo possível devido à evolução do que é ser criança e a importância que foi dado ao momento especifico da infância (KISHIMOTO, 2009).

A educação de uma criança pequena envolve dois processos complementares e indiscutíveis, que é o educar e cuidar. As crianças desta faixa etária, como sabem, têm necessidades de atenção, carinho, segurança, sem as quais elas dificilmente poderiam sobreviver. Simultaneamente, nesta etapa, as crianças têm o contato com o mundo que as cerca, através das experiências diretas com as pessoas e as coisas deste mundo e com as formas de expressão que nele ocorrem.

Diante disso, a inserção das crianças no mundo atual não seria possível sem que houvesse atividades voltadas simultaneamente para cuidar e educar. O que se tem verificado, na prática, é que tanto os cuidados como a educação têm sido entendidos de forma muito estreita. Cuidar tem significado, na maioria das vezes, realizar as atividades voltadas para os cuidados primários: higiene, sono, alimentação (FREIRE, 2002).

No âmbito da educação, cuidar inclui preocupações que vão desde a organização dos horários de funcionamento da creche, compatíveis com a jornada de trabalho dos responsáveis pela criança, passando pela organização do espaço, pela atenção aos materiais que são oferecidos, como brinquedos, pelo respeito às manifestações da criança e até a consideração de que a creche não é um instrumento de controle da família (FREIRE, 2002).

Este processo que faz com que a criança passe a participar de uma experiência cultural, que é própria de seu grupo social é o que se chama de educação. No entanto, esta participação na experiência cultural não ocorre isolada, fora de um ambiente de cuidados, de uma experiência de vida afetiva e de um contexto material que lhes dá suporte (OLIVEIRA, 2000).

A noção de experiência educativa que percorre as creches e pré-escolas têm variado bastante. Quando se trata de crianças das classes populares, muitas vezes a prática tem-se voltado para as atividades que têm por objetivo educar para a submissão, o disciplinamento, o silêncio, a obediência.

De forma perversa, também ocorrem experiências voltadas para o que chamamos de alfabetização precoce, igualmente disciplinadoras no seu pior sentido. Em outras palavras, as experiências que trazem para os jardins de infância, especialmente o 


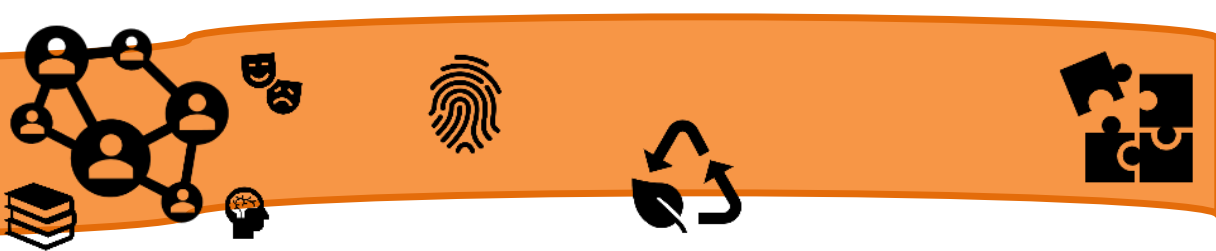

modelo da escola fundamental, as atividades com lápis e papel, os jogos ou atividades realizadas na mesa, a alfabetização precoce, o cerceamento do corpo, a rigidez dos horários e da distribuição das atividades, as rotinas repetitivas, pobres e empobrecedoras (OLIVEIRA, 2000).

Sem o uso das brincadeiras o processo de aprendizagem das crianças seria mais lento, pois é necessário que a construção se faça a partir dos jogos, brincadeiras e da imaginação. Brincar é primordial, pois, esta é a maneira que o sujeito humano, utiliza para se estruturar como sujeito da emoção, da razão e da relação. Assim, as práticas pedagógicas a serem desenvolvidas nas instituições educacionais devem ser contextualizadas, possibilitando a construção de sentido para as crianças, melhorando sua qualidade de relações próprias da vida (SILVA; SANTOS, 2009).

Para a Educação Infantil, é importante um professor que tenha uma qualificação mínima para a docência, um professor capaz de desenvolver um trabalho que possibilite à criança a promoção de uma construção compartilhada, favorecendo sua autonomia e criatividade. Além disso, precisa-se de incentivos dos governantes e ferramentas necessárias para um trabalho de qualidade o que não acontece na prática (SILVA; SANTOS, 2009).

\section{O LÚdico NO DESENVOLVIMENTO E AS CONTRIBUIÇÕES DAS ATIVIDADES LÚDICAS}

Etimologicamente o termo lúdico tem origem na palavra latina "ludus", que significa jogo, o que leva a crer na existência de sua relação apenas com o ato de jogar, o divertimento, o entretenimento, as brincadeiras sem nenhuma intenção socioeducativa. Somente depois de acurados estudos, o lúdico passou a ser considerado como meio de compreender e intervir nos processos cognitivos das crianças, se constituindo como um desafio ao pensamento do aluno, por instigar o raciocínio, desenvolver habilidades motoras, cognitivas e socioafetivas na busca de resultado favorável às atividades que lhe são propostas, possibilitando a aquisição de aprendizagem nos mais variados âmbitos (BRACHT, 2003).

Apesar de seu uso constante na língua portuguesa os significados atribuídos ao lúdico são ainda bastante obscuros. De acordo com Bracht (2003) sua maior utilização no Brasil, diz respeito ao estudo deste termo associado ao lazer. Este autor ressalta ser 


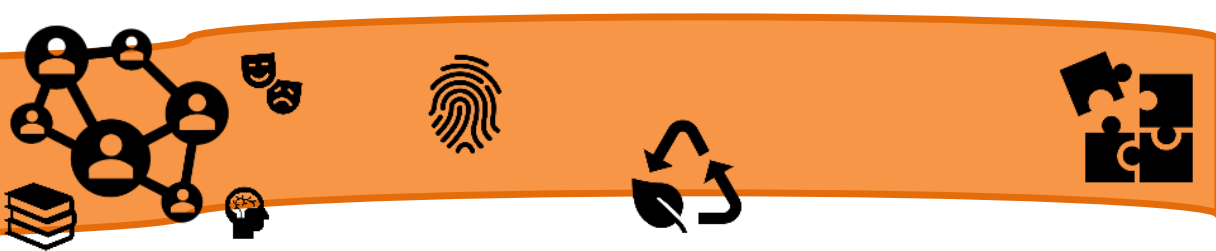

sua preocupação não apenas o uso da expressão "lúdico", mas o significado com que se emprega esta palavra.

Diante disso, a importância da inclusão dos jogos e das brincadeiras para a Educação Infantil demonstra o brincar como uma estratégia de aprendizagem, que possibilita o desenvolvimento cognitivo da criança e apresenta o lúdico como ferramenta importante para a aprendizagem (MALUF, 2003).

É importante esclarecer a importância do brincar e propor estratégias metodológicas que possibilitem o desenvolvimento cognitivo do educando, demonstrando as possíveis consequências da não utilização desta metodologia no ambiente escolar (LOPES, 2005).

A brincadeira aparece como um importante componente da Educação Infantil, mas como uma ferramenta para a aprendizagem, e sua ausência aparece como um defeito, pois o brincar ajuda os professores a analisar a criança de forma mais completa, de fato, o item brincar auxilia muito na aprendizagem das crianças, e vem no mesmo nível que imitação, oposição, linguagem e imagem corporal (REGO, 1995).

A ausência da brincadeira na Educação Infantil vem sendo discutido na literatura, sendo apontadas as limitações e suas distorções, entre as quais a ausência de reconhecimento do caráter que o motiva a brincar, a crença na necessidade de orientar a brincadeira em certas direções e assim sofrendo implicações dessas concepções para a vida da criança, bem como os impactos no seu desenvolvimento futuro (SANTOS, 2002).

As brincadeiras na infância estão cada vez mais raras, o momento que se passa é de uma revolução tecnológica e isso está afetando as crianças de uma maneira geral, o desenvolvimento de certas habilidades nas crianças devido as mídias sociais, e os jogos de videogames, assim, seguem sendo prejudicados (VALLE, 2019).

O brincar é fundamental para que o desenvolvimento aconteça, dando asas à sua autonomia através do brincar e se libertando individualmente. A falta de brincadeiras também causa inseguranças nas crianças.

A criança com a falta de criatividade ou imaginação acaba afetando o seu desenvolvimento, esse elemento é essencial para a vida humana, porque ajuda a resolver os problemas e a lidar com diferentes situações. A criança usa sua imaginação para criar um mundo em que a brincadeira é o principal item a ser empregado, e onde sua 
imaginação o faz viajar por várias histórias. Já está comprovado que a falta de brincadeira dificulta essa habilidade, tornando o pensamento mais original (VALLE, 2019).

O professor estimular atividades na infância é essencial para ajudar no crescimento saudável. No Brasil, muitas vezes esse direito é negligenciado ao participar de brincadeiras estimulantes e interagir com os colegas, é a parte fundamental da vida de uma criança, porque através da interação com outras crianças com pensamentos diferentes acaba sendo realizada uma troca de conhecimento, uma forma de aproximação e aprendizado sem falar que pode ocorrer uma troca de brincadeiras novas e desconhecidas (QUEROZ, 2002).

A criança tem o direito de brincar e se divertir, isso é assegurado na constituição, porém nem todas as escolas seguem à risca pois muito tem a ver com a falta de investimentos e recursos.

Através da brincadeira, a criança aprende a ter empatia e se colocar no lugar do outro. No Brasil, muitas crianças são privadas de brincar de forma saudável, o que compromete o desenvolvimento e pode trazer consequências no futuro ao romper a ligação dos pequenos com o ato de brincar, e se perde a oportunidade de desenvolver o sistema cognitivo e motor (BASSEDAS, 1999).

Segundo Macedo (2006, p. 35):

A atividade lúdica é aquela que se executa no jogo. Lúdico relacionase tanto com jogo como com brinquedo; refere-se a qualquer objeto ou atividade que vise mais ao divertimento que a qualquer outro propósito; por fim, é o que se faz por gosto, sem outro objetivo que o próprio prazer de fazê-lo.

Os elementos lúdicos ligados ao ato de brincar, atividade física ou mental fundada em sistema de regras que definem a perda ou o ganho, definido aos termos em questão remetendo as ideias de jogos, ação de jogar, brincar, brincadeira, divertimento. Vale ressaltar ainda que, existem tipos de jogos que afetam o psicológico do brincante, neste caso a melhor solução é a monitoração dos pais, de forma a evitar tragédias que ocorrem através desses tipos de jogos (MARINHO, 2007).

Compreende-se com isso que, as atividades lúdicas favorecem a possibilidade da criança conviver com sentimentos diversos que fazem parte de seu mundo interior, externando por meio das brincadeiras seus desejos e fantasias de construção do mundo 


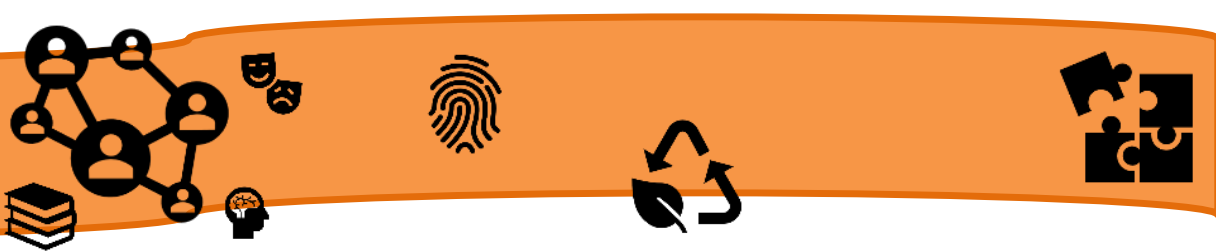

exterior no qual sonha viver e que nem sempre está ao seu alcance, mas que a ele viaja por meio da imaginação e da fantasia, expressando por meio das brincadeiras o que na realidade gostaria de revelar.

Portanto, as atividades lúdicas possibilitam uma relação com as brincadeiras de modo a levar o aluno a desenvolver sua personalidade, formular novas ideias, atitudes, criar, inovar e aprender e formular conceitos morais e éticos e até a desenvolver múltiplas inteligências, dada a funcionalidade, espontaneidade, satisfação e o prazer que gera no mesmo, ao desenvolver atividades práticas.

\section{CONSIDERAÇÕES FINAIS}

O trabalho realizado sobre as contribuições das atividades lúdicas, é importante para a jornada acadêmica de uma maneira geral, pois adquire-se um conhecimento vasto sobre o lúdico e com a prática observada, é importante para o aprendizado e convívio entre os alunos.

De acordo com os dados obtidos, mostrou-se que o lúdico pode contribuir de forma significativa para o desenvolvimento integral das crianças, além das professoras exercerem um papel importante nesse processo entendendo que essa prática contribui de forma satisfatória.

O lúdico contribui de forma significativa e prazerosa para o desenvolvimento da criança, auxiliando não só na aprendizagem, mas também no desenvolvimento social, pessoal e cultural, facilitando no processo de socialização, comunicação, expressão e construção do pensamento. O brincar não é apenas passatempo, podendo ser usado na aprendizagem e no desenvolvimento das crianças de forma dirigida e com objetivos.

Vale ressaltar que o lúdico não é a única alternativa para a aprendizagem com crianças, mas é um auxílio bastante enriquecedor, promovendo prazer ao aprender. A Educação Infantil deve considerar o lúdico como parceiro na prática pedagógica para atuar no desenvolvimento e na aprendizagem das crianças. Além disso, percebeu-se o quanto é essencial a utilização de recursos e atividades lúdicas como estratégias pedagógicas no ambiente escolar, como suporte na construção de conceitos pela própria criança de forma prazerosa.

\section{REFERÊNCIAS}




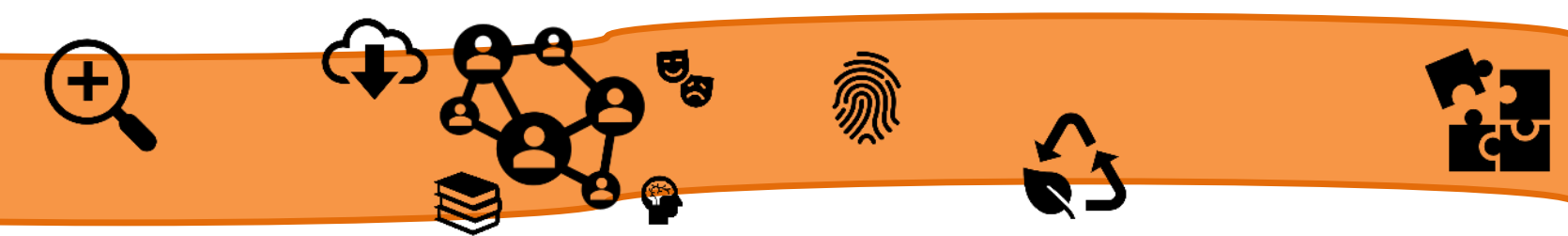

BASSEDAS, E, HUGUET, T. e SOLÉ, I. Aprender e ensinar na educação infantil. Porto Alegre: Artmed, 1999

BRACHT, V. A constituição das teorias pedagógicas da Educação Física. Caderno CEDES, ano XIX, nº 48, p.69-89, agosto 2003.

FREIRE, Paulo. Pedagogia da autonomia: saberes necessários à prática educativa. SãoPaulo: Paz e Terra, 2002.

HAETINGER, M, G. CNS, Jogos, recreação e lazer. Unidade I. Curitiba: IESDE, 2004.

KISHIMOTO, Tizuko Morchida. Jogo, brinquedo e brincadeiras e a Educação Infantil. 12. ed. São Paulo: Cortez, 2009.

LOPES, Maria da Gloria. Jogos na educação: criar, fazer, jogar/ Maria da Gloria Lopes. 6. ed.- São Paulo, Cortez, 2005.

MALUF, Ângela, Cristina Munhoz. Brincar: prazer e aprendizado. Petrópolis: Vozes, 2003.

MACEDO, L; PETTY, A.L.S; PASSOS, N.C. Os jogos e o lúdico na aprendizagem escolar. $1^{\text {a }}$ Ed. Porto Alegre: Artmed, 2006.

MARINHO, Herminia Regina Bugeste. Pedagogia do movimento universo lúdico e psicomotricidade. 2. ed. Curitiba: IBPEX, 2007.

OLIVEIRA, Vera Barros de (org). O brincar e a criança do nascimento aos seisanos. Petrópolis, RJ: Vozes, 2000.

QUEROZ, T.D. e MARTINS, J.L. Jogos e Brincadeiras de A a Z. São Paulo. São Paulo: Rideel, 2002.

REGO, Teresa Cristina. Vygotsky: uma perspectiva histórico-cultural da educação. Petrópolis, RJ: Vozes, 1995.

SANTOS, Santa Marli Pires dos. O lúdico na formação do educador. 5 ed. Vozes, Petrópolis, 2002.

SILVA, A.F.F; SANTOS, E.C.M. A Importância do Brincar na Educação Infantil. Rio de Janeiro, 2009. Tese (Curso de Especialização "Desafios do Trabalho Cotidiano: A Educação das Crianças de 0 a 10 Anos) - Universidade Federal Rural do Rio de Janeiro; UFRRJ, 2009.

VALLE, Ribeiro do. O brincar. 2019. (online) Disponível na Internet via: http://www.ribeirodovalle.com.br/brincar.htm >. Acesso em 13/01/2020. 


\title{
O FAIR TRADE COMO ESTRATÉGIA ÀS AGROINDÚSTRIAS FAMILIARES
}

\author{
BIANCHINI, Giovana ${ }^{46}$ \\ FAGHERAZZI, Onorato Jonas ${ }^{47}$
}

\section{RESUMO:}

O fair trade ou comércio justo alude a uma análise das desigualdades históricas próprias do comércio internacional e a crença de que o mesmo pode ser mais socialmente equitativo. Essa ciência está cada vez mais unida a um conjunto de ações que impacientam as desigualdades globais significando que o valor do trabalho humano não é o mesmo para todos. Em meio a essa percepção à abordagem alternativa do Fair Trade, prática esta que está em plena ascensão no cenário internacional, conforme Cantalice et al (2010), busca romper o comércio convencional se fundamentando em uma parceria entre produtores e consumidores, oferecendo aos primeiros negócios diretos com o consumidor final e por consequência a ampliação da margem de venda. Mas, como tornar o trabalho do campo mais atrativo através do aumento de renda e justiça social? Para tanto, o presente estudo investigou através da análise de conteúdo de Bardin (1977), os conhecimentos de 20 agricultores que fazem a gestão de 20 diferentes agroindústrias familiares de pequeno porte de produção artesanal na Quarta Colônia de Imigração Italiana do RS sobre o comércio justo. Tendo não observada a informação dos mesmos quanto a possível certificação do fair trade, buscou-se orientá-los à adoção de técnicas e métodos que possam agregar mais valor a seus produtos ao suprimir atravessadores e garantindo o aumento de renda e valor às suas agroindústrias.

PALAVRAS-CHAVE: Fair trade. Agroindústrias familiares. Gestão estratégica.

\section{INTRODUÇÃO}

Dentre as práticas usuais de produção de produtos orgânicos com baixo impacto ambiental, com uma distribuição do lucro mais justa frente ao esforço e trabalho para sua obtenção e à oposição às grandes redes de produção agroalimentar surge um conceito chamado de "Fair Trade", traduzido literalmente como "Comércio Justo". Apesar de que as vendas de Fair Trade conforme Becchetti e Huybrechts (2008), não atingiram $0,01 \%$ do volume total do comércio mundial, o índice de crescimento dessa nova tendência de produção-consumidor final faz com que ele seja um importante fenômeno global. Embora que o conceito de Fair Trade não seja um consenso, o

\footnotetext{
${ }^{46}$ Doutora em Desenvolvimento Regional pela Universidade de Santa Cruz do Sul (UNISC). Professora Instituto Federal de Educação, Ciência e Tecnologia do Rio Grande do Sul (IFRS). E-mail: giovana.bianchini@bento.ifrs.edu.br

${ }^{47}$ Doutor em Educação em Ciências pela Fundação Universidade de Rio Grande (FURG). Coordenador do Curso Técnico em Viticultura e Enologia Integrado ao Ensino Médio do Instituto Federal de do Rio Grande do Sul (IFRS) - Campus Bento Gonçalves. E-mail: onorato.fagherazzi@ bento.ifrs.edu.br
} 
discurso foca em como cadeias historicamente exploradoras entre produtor e consumidor podem ser reestruturadas baseadas em ideias de justiça e equidade (RAYNOLDS, 2002).

Também para Raynolds (2002), o futuro da adoção de mercado do Fair Trade por pequenos produtores rurais é imprevisível porque talvez a sua verdadeira importância não esteja no acréscimo do valor agregado ao produto, mas sim em extinguir a divisão norte/sul e criar vínculos entre o produtor e o consumidor final.

Gereffi (1999), esboça três pilares da cadeia global de commodities que são: a articulação de produtos que adicionam margem de custos ao consumidor final; a territorialidade das empresas que formam redes de produção e marketing; e as relações de poder que determinam como os recursos são alocados. Nesse sistema de produçãodistribuição e consumo global não se percebe a figura e a importância do agricultor familiar; este compreendido pela Lei 11.326 como aquele que utiliza, predominantemente, mão de obra da própria família nas atividades econômicas de seu estabelecimento ou empreendimento e o dirige com a mesma. Para que o agricultor familiar tenha acesso à Política Estadual de Agroindústria Familiar, a Lei 13.921 (BRASIL, 2012) exige que os estabelecimentos com pequena escala de produção sejam geridos diretamente por esses agricultores familiares com meios de produção próprios ou mediante contrato de parceria.

Para esse auxílio foram também criados pelo governo do Estado do RS os Decretos 49.341 e 49.948, que visam proporcionar a criação e a manutenção de chances de trabalho para o conjunto dos membros das famílias, viabilizando a sua manutenção nas áreas agropecuárias e pesqueiras; baseando-se na sustentabilidade ambiental, social e econômica e reduzir os desequilíbrios regionais, sociais e ambientais, respectivamente.

A partir desses pressupostos legais, foram analisadas, neste artigo, 20 agroindústrias da 4 a Colônia de Imigração Italiana do RS, para que se proponha, posteriormente, nova estratégia comercial como a do fair trade.

\section{O MÉTODO E A PESQUISA DE CAMPO}




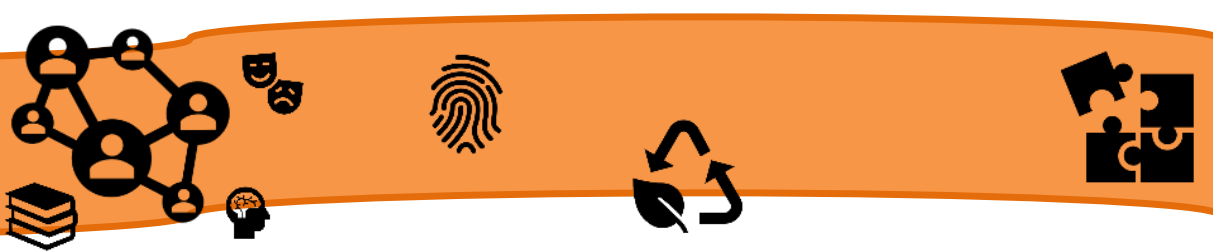

A investigação foi realizada nas agroindústrias familiares de pequeno porte de processamento artesanal, situadas nos municípios da Quarta Colônia de Imigração Italiana no RS: Dona Francisca, Pinhal Grande, Restinga Seca, Ivorá, Faxinal do Soturno, Silveira Martins, Nova Palma, Agudo e São João do Polêsine diretamente com os agricultores familiares envolvidos no negócio - com os próprios proprietários. Buscou-se analisar a forma como eles administravam suas agroindústrias, a logística de distribuição e, se conheciam o fair trade, ou, outras estratégias para agregação de valor aos seus produtos. A análise de dados seguiu a análise de conteúdo (BARDIN, 1977).

A variável integrante da agroindústria concentra a análise sobre os agricultores familiares envolvidos no processo de transformação da matéria-prima em produto final, nas atividades diretamente relacionadas aos processos de operação na agroindústria, como esses, pela sua atuação nesse processo, contribuem à identidade local, regional, manutenção de seus status quo e como criam e mantêm relações sociais através da ligação com a agroindústria familiar de pequeno porte de processamento artesanal na qual estão envolvidos.

Portanto, os agricultores familiares conformam as práticas nas agroindústrias pelo modo como dirigem as suas ações, transformando-se em atores ativos do processo de construção social da estratégia nesse ramo. Buscou-se, então, identificar as características desses atores, por meio da compreensão sobre quem eles são, como ocorreu a criação e/ou perpetuação da agroindústria e como é realizada a sua gestão. A Tabela 01 expõe a configuração dos integrantes das agroindústrias.

Tabela 01 - Integrantes das agroindústrias

\begin{tabular}{c|c|c}
\hline Integrantes & Quantidade de agroindústrias & $\%$ \\
\hline Agricultor familiar e esposa & 17 & $85 \%$ \\
\hline $\begin{array}{c}\text { Agricultor familiar, esposa e } \\
\text { filho(s) }\end{array}$ & 2 & $10 \%$ \\
\hline $\begin{array}{c}\text { Agricultor familiar, esposa, } \\
\text { filhos e neto }\end{array}$ & 1 & $5 \%$ \\
\hline Total & 20 & $100 \%$ \\
\hline
\end{tabular}

Fonte: Elaborado pelos autores

Como pode ser observado na Tabela 01, 85\% das famílias pesquisadas são constituídas pelo agricultor familiar e sua esposa. Em dois casos, percebeu-se a ação conjunta do filho do casal; noutro, a família nuclear estendida, contando inclusive com a atuação do neto do fundador. A agroindústria é centrada nas atividades realizadas 
exclusivamente pelos membros da família; onde, os proprietários estabelecem a esperança de sustentabilidade econômica por meio dela. Na sequência, o perfil dos entrevistados.

Tabela 02 - Perfil dos agricultores familiares

\begin{tabular}{c|c}
\hline Características & Agricultor familiar \\
\hline Faixa etária & $45-68$ anos \\
\hline Escolaridade & $1^{\circ}$ incompleto \\
\hline Tamanho da propriedade & Até 4 módulos fiscais \\
\hline
\end{tabular}

Fonte: Elaborado pelos autores

Já a manutenção social destes agricultores e seus familiares no campo está diretamente vinculada com a capacidade de conservar ou melhorar a sua qualidade de vida, pela renda obtida com a operação da agroindústria, mantendo e garantindo recursos para as próximas gerações. Para Pitombo (2015):

A redução da pobreza por meio do comércio constitui um elemento chave da WFTO (World Fair Trade Organization). A organização apoia pequenos produtores marginalizados, podendo ser independentes, empresas familiares, ou agrupados, como também, em associações ou cooperativas. Fomenta a autossuficiência e a autonomia econômica propondo planos de ação eficientes.

Além de ser peculiar a predominância do núcleo familiar na agroindústria, o agricultor familiar emprega as suas próprias concepções de estratégia nessa atividade, mantendo a pequena escala de produção e as ligações locais de proximidade com os mercados, muitas destas, por vezes, informais. Dentre as alternativas estratégicas na busca de soluções para alcançar uma sociedade mais justa, pode-se perceber o fair trade como uma estratégia de negócios que consiste, segundo a WFTO (2001), em:

Uma parceria comercial, baseada em diálogo, transparência e respeito, que procura maior equidade no comércio internacional. Contribui para o desenvolvimento sustentável através da oferta de melhores condições comerciais e ao garantir os direitos dos produtores e trabalhadores.

Em prol da sustentabilidade econômica, observa-se a necessidade de haver um processo de integração desses agricultores com o mercado competitivo. O comércio justo, nesse sentido, poderia ser um meio para tal fim. Assim sendo, esta nova prática nessas agroindústrias familiares de pequeno porte de processamento artesanal poderia 


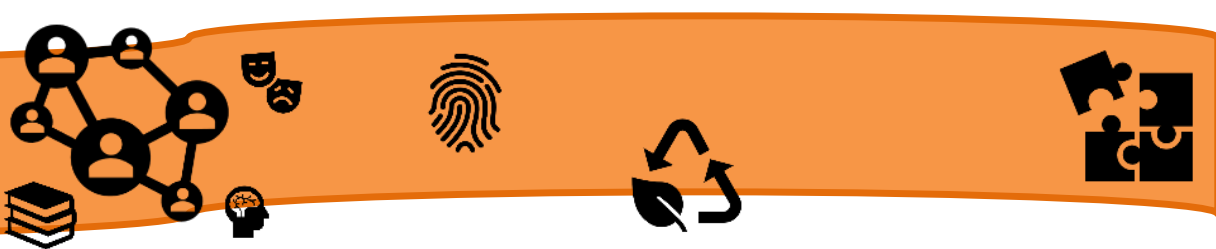

oportunizar vida longa as mesmas. Mas como elas poderiam adotar tais práticas sustentáveis?

\section{O FAIR TRADE COMO ESTRATÉGIA ÀS AGROINDÚSTRIAS FAMILIARES}

Segundo os agricultores familiares, as operações nas agroindústrias são descritas a partir de opiniões abaixo explanadas:

a) "A gente (agricultor familiar e esposa) procura fazer assim... pagar as contas e não deixa acumular, né e as prestações aqui da agroindústria que a gente fez financiado a gente vai pagando";

b) "Os controles aqui são tudo manual a gente não usa planilhas, tudo na base do lápis. É nós fizemos isso, por exemplo, mas a gente procura deixar uma pessoa (esposa) só pagar/fazer pagamento para não ter muita confusão e tal, mas poderia ser bem mais bem organizado, é...";

c) "É tudo no dinheiro e no caderninho";

d) "Não utilizamos nenhum instrumento de administração é tudo pela prática. Não temos nenhum tipo de gestão financeira, a gente vende toda semana, daí chega na segunda de manhã, a gente tira tanto no mercado, dois três mercados que a gente compra, a gente pega para a semana e na segunda-feira a gente vai lá e faz o pagamento, depois paga as contas e divide";

e) "Eu gerencio o meu negócio pela prática".

f) "Eu acho que vou continuar assim produzindo o melado no período do inverno e depois cuidando do meu arroz... (risos)".

Percebe-se que nenhum dos entrevistados mencionou a busca por auxílio externo à gestão da agroindústria ou de novos conceitos como o de Fair Trade, que visam otimizar melhores retornos advindos de maiores responsabilidades socioambientais e comercialmente justas. Esse fato sucede em função do próprio agricultor familiar e/ou membro da família está gerindo todas as etapas intrincadas nas operações da agroindústria e sua logística, muitas vezes sem nenhuma assistência à gestão.

Para Moore (2004), o Fair Trade gera parcerias com características tais como:

a) a ênfase na relação direta entre comprador e a ênfase na relação direta entre comprador e organizações de produtores;

b) prestação de algum nível de apoio contra flutuações de preços;

c) o pagamento de um prêmio direto ao produtor ou um prêmio social a ser utilizados em benefício da comunidade, em vez de produtores individuais; 
d) a prestação de pré-financiamento (geralmente $50 \%$ ou $60 \%$ do valor final da ordem) para produtores como parte de uma relação comercial estável, de longo prazo;

e) a prestação de informações aos produtores sobre design, a demanda, preços, regras e regulamentos.

Conforme a Tabela 03, a gestão das agroindústrias, centralizada no agricultor familiar, provoca o advento de determinadas dificuldades, como centralização das decisões, dedicação à agricultura familiar, falta de pessoal capacitado, financiamento das estruturas das agroindústrias, controle empírico de gestão e falta de organização de documentos.

Tabela 03 - Dificuldades de ordem de gestão enfrentadas pelas agroindústrias

\begin{tabular}{c|c}
\hline Dificuldades & Quantidade de agroindústrias \\
\hline $\begin{array}{c}\text { Centralização das decisões na figura do } \\
\text { agricultor familiar }\end{array}$ & 20 \\
\hline Dedicação à agricultura familiar & 20 \\
\hline Falta de pessoal capacitado & 20 \\
\hline $\begin{array}{c}\text { Inexistência de retorno financeiro no primeiro } \\
\text { ano da agroindústria }\end{array}$ & 20 \\
\hline Controle empírico de gestão & 19 \\
\hline Falta de organização de documentos & 15 \\
\hline
\end{tabular}

Fonte: Elaborado pelos autores

Conhece-se que com relação ao auxílio à gestão das agroindústrias, o Decreto 49.948 propõe-se à implantação de bases de serviços de apoio à gestão e à prestação de serviços técnicos multidisciplinares, imprescindíveis ao processamento agroindustrial e ao controle da qualidade, da gestão financeira e contábil, à publicidade e à comunicação, à distribuição e à comercialização. Apesar dos esforços do poder público, não é explicitado pelo Decreto 49.948 como o mesmo almeja constituir a implantação de bases de serviços de apoio no auxílio à gestão da agroindústria e como será constituído e ocorrerá a prestação dos serviços técnicos multidisciplinares. Também não é mencionado como ocorrerá o acompanhamento das EMATER's municipais à inserção das agroindústrias, ao auxílio à gestão financeira e contábil, à publicidade, à comunicação, à distribuição e à comercialização.

Por essa precariedade, desconhecimento e insegurança sobre o auxílio externo que iriam receber, os agricultores familiares acabam conservando as práticas de gestão sob características empíricas nas quais se constituíram. A esse contexto e pela unidade de processamento artesanal de alimentos estar fundamentada nos esforços dos indivíduos pertencentes a um mesmo cerne familiar, tem fomentado novas ponderações 


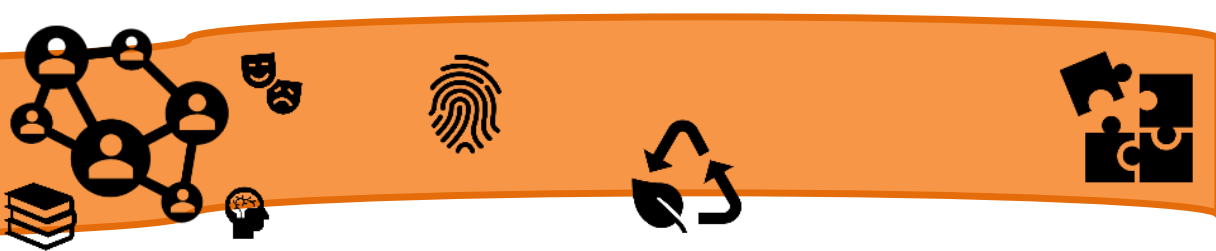

de nossa parte para que se possa mediar novas práticas imbricadas em processos emancipatórios a partir dos pressupostos e dos princípios da economia justa e solidária. Isso pois, como Freire (2000, p. 66) nos diz:

Urge que assumamos o dever de lutar pelos princípios éticos mais fundamentais como o respeito à vida dos seres humanos, à vida dos outros animais, à vida dos pássaros, à vida dos rios e das florestas. Não creio na amorosidade entre homens e mulheres, entre os seres humanos, se não nos tornarmos capazes de amar o mundo. A ecologia ganha uma importância fundamental neste fim de século. Ela tem de estar presente em qualquer prática educativa de caráter radical, crítico ou libertador [...] Desrespeitando os fracos, enganando os incautos, ofendendo a vida, explorando os outros, discriminando o índio, o negro, a mulher, não estarei ajudando meus filhos a serem sérios, justos e amorosos da vida e dos outros.

Uma dessas formas de se lutar por mais igualdade social é o fair trade. O fair trade é uma certificação que surgiu na segunda metade do século passado com o objetivo de "garantir que os produtores recebessem a devida remuneração pelo seu trabalho e criasse condições sociais mais justas”. (ECOCASA, 2018, p. 1).

Embora ainda pouco difundido em nossas sociedades ameríndias, o fair trade é guiado por dez princípios:

1 - Criação de oportunidades para produtores economicamente desfavorecidos;

2 - Transparência e responsabilidade na troca de informação e na tomada de decisões;

3 - Práticas comerciais justas, estáveis, duradouras, em respeito pelo bem-estar social, ambiental e econômico dos pequenos produtores; 4 -

Pagamento de um preço justo pelo trabalho dos produtores, sem desigualdades entre géneros;

5 - Renúncia total ao trabalho infantil ou forçado;

6 - Compromisso de não discriminação, igualdade de géneros e liberdade de associação; 7 - Assegurar boas condições de trabalho, saudáveis e seguras

8 - Incentivo à capacitação dos produtores e desenvolvimento das suas competências; 


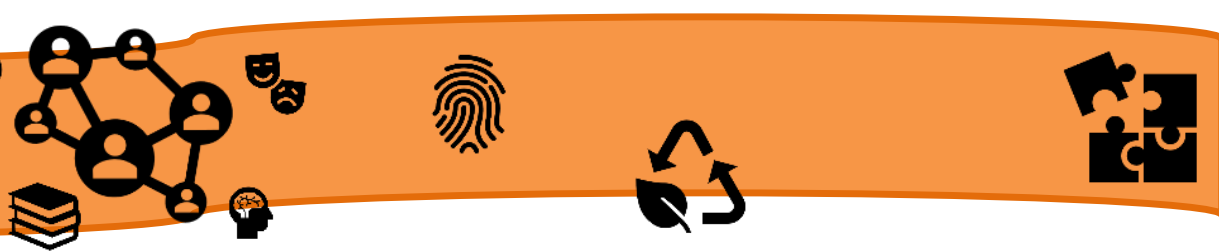

9 - Promoção dos princípios do Comércio Justo aos consumidores

10 - Respeito pelo ambiente: Recurso a matérias-primas provenientes de fontes exploradas de forma sustentável; Redução consumo energético e uso de tecnologias com baixas emissões de GEE; Redução impacto dos resíduos produzidos no ambiente; Primazia a métodos de produção biológica e a produtos reciclados ou biodegradáveis. (ECOCASA, 2018, p. 1).

Segundo o Connectamericas (2018), o fair trade gera benefícios para mais de 1,2 milhão de famílias de agricultores em mais de 70 países em desenvolvimento. Trata-se de um sistema de certificação e rotulagem administrado pela Fair Trade International (FLO), uma associação multilateral sem fins lucrativos composta por 24 organizações, que é responsável pela auditoria de produtos em toda a cadeia de fornecimento, desde o produtor, o comerciante, até o produto final.

O fair trade apropriou-se de uma fatia de mercado muito forte. Por exemplo: $53 \%$ das bananas vendidas nos supermercados da Suíça; ou, 22\% do pó de café comercializado no Reino Unido já são dos produtos daquela referida distinção. Atualmente, mais de 27.000 produtos com o selo Fair trade são vendidos em mais de 115 países.

Alinhados a essas novas tendências do comércio mundial, cientes de seus benefícios sociais ao fomentar maior valorização do produto, uma vez que traz garantias de ser eticamente e ambientalmente corretos, são práticas de novos processos emancipatórios de uma requerida economia justa e solidária a ser incentivada nas agroindústrias pesquisadas cujo tema está sendo explanado através de cursos do próprio Freire Institute europeu (2018).

\section{CONCLUSÃO}

A presente pesquisa objetivou pesquisar conceitos correlatos ao trabalho de gestão em agroindústrias familiares no anseio de apoiá-las para que se mantenham como pequenas propriedades produtivas, impedindo o êxodo rural, o que se desenvolveu em uma entrevista com 20 proprietários de agroindústrias familiares.

A presente ação investigativa adotou a metodologia de análise de conteúdo. E, não se tendo observado ainda qualquer ocorrência de conceitos como o de trade fair em suas práticas mercantis, observado que esta é uma testa impulsionadora de um resultado 



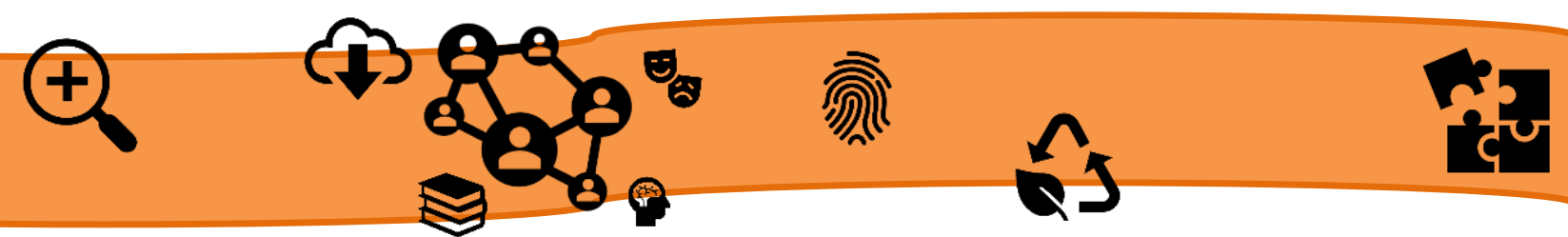

RAYNOLDS, L. T. Consumer/Producer Links in Fair Trade Coffee Networks, Sociologia Ruralis. Europa, v. 42, n. 4, p. 404-424, 2002. 



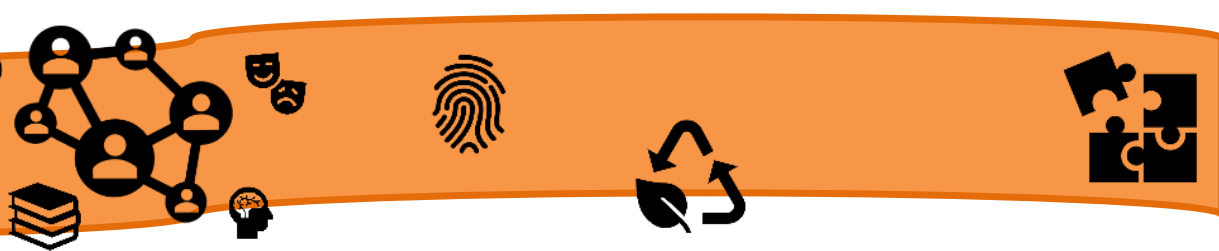

O preconceito com a diferença de cor, principalmente com negros, é uma realidade histórica, uma construção inicialmente geográfica e, consequentemente, social e cultural, ainda que os primeiros registros de hominídeos venham da África, não há valorização histórica após a expansão desses grupos para outras partes.

Depois de milhões de anos, há uma volta de outras gerações para "colonização", sempre numa perspectiva de transformar o "outro" em "nós", nessa transformação há a desconsideração dos negros, surgindo escravidão e etc., assim ocorre nos Estados Unidos (onde se passa o filme), no Brasil (de forma atual) e entre tantos outros países. As sociedades são assim construídas com suas bases no preconceito e na indiferença com os que são diferentes dos seus colonizadores e líderes: na sua maioria, homens e brancos. São criados, dessa forma, tabus históricos e sociais, acerca dos negros, que os empurram a pobreza, a margem das sociedades, assim como outras raças que fujam dessa realidade de "normalidade."

\section{ANÁLISE DO LIVRO: O ÓDIO QUE VOCÊ SEMEIA}

O livro "O ódio que você semeia", de Angie Thomas, é uma história juvenil que retrata de forma muito atual como as raízes do preconceito estão presentes e crescendo na sociedade. A história se passa em Garden Heights, uma comunidade pobre formada majoritariamente por negros na Georgia, no Sul dos Estados Unidos. Tem como protagonista a jovem Starr Carter, filha de um ex-traficante e que vive a trama de perder seu amigo de infância, Khalil, de forma injusta por conta de sua cor. Ela aprende desde pequena como se portar na frente de um policial. Se um dia for parada pela polícia porque fez besteira dirigindo ou simplesmente por nada, em todas as ocasiões tem um modo de proceder "adequadamente": pôr as mãos abertas e paradas sobre o painel, sempre onde possa ver; não argumentar contra eles; ser obediente. Apesar disso, seu pai sempre lembrava a jovem e seus dois irmãos que é uma honra ser negro e que vieram da grandeza.

Percebemos o quanto os marcadores trabalham em teia, não é só uma diferença, mas todo o contexto do ser. Uma outra problemática do filme é a vida dupla de Starr por conta da escola "de branco" onde estuda, ela age diminuindo o tom de sua negritude: não usa as gírias de "negros", casacos de "favelados", nem nada que possa acusá-la de ser negra. Ela tenta se "embranquecer" para se encaixar melhor no novo ambiente, 
enquanto observa seus colegas brancos ouvirem hip-hop e tentarem agir como negros (para seus colegas, eles podem ter a atitude de um negro e continuarem inofensivos aos olhos da sociedade, sem serem estigmatizados como "favelados").

A opressão causada pelo preconceito atinge de forma tão complexa e completa o indivíduo que causa uma desconstrução da sua própria identidade. Está tão incutido na sociedade um "padrão", que quem está fora do limite "aceitável", acaba se acomodando e aceitando os olhares indiferentes como normal ou reprimindo-se para não causar desconforto no próximo.

Durante uma briga em uma festa, Khalil leva Starr de carro para casa. A rua estava vazia e no caminho, passou de uma mão para a outra da pista sem sinalizar e foi parado pela polícia. Starr põe em prática as instruções que recebeu do pai e orienta o rapaz a acompanhar, este o faz relutantemente. $\mathrm{O}$ policial ao receber

questionamentos sobre o motivo pelo qual parou o carro, logo altera o tom de voz e não aceita ser contra argumentado, ameaçando-o e fazendo com que o jovem saísse do carro. Revista-o e faz perguntas como: “tem drogas?" "de onde conhece a garota?" "estavam procurando uma boca?". Quando Starr pega o telefone para gravar o ocorrido, é gritada pelo policial em tom de ameaça. Logo, solta o aparelho rapidamente ao chão do transporte. Volta até a viatura para conferir a documentação. Enquanto isso, os dois jovens conversam tentando descontrair o nervosismo da garota. Quando Khalil segura uma escova de cabelo presente nos seus pertences, o policial imediatamente atira (ainda de longe) afirmando que o rapaz estava armado. Ao perceber o erro cometido, chama uma ambulância, mas a vítima não resiste.

Tanto o "tira" assassino quanto parte da sociedade acreditam que ele agiu em legítima defesa, pois um jovem negro por si só já é bastante suspeito. Para a surpresa de quem acompanha a história, o próprio tio de Starr - policial negro, diga-se de passagem - admite que teria atuado de forma semelhante e que se estivesse em um bairro rico e parasse um rapaz branco bem vestido, o modo de proceder seria diferente: primeiro seria advertido a soltar o que tivesse em mãos, por mais suspeito que fosse, e só depois, se necessário, atiraria.

A diferença no procedimento do policial exclusivamente pela cor do suspeito é uma forma de racismo. Após o assassinato de Khalil, Starr percebe que os estudantes "brancos" apoiam o policial que teria agido por legítima defesa e usam isso para fazer 


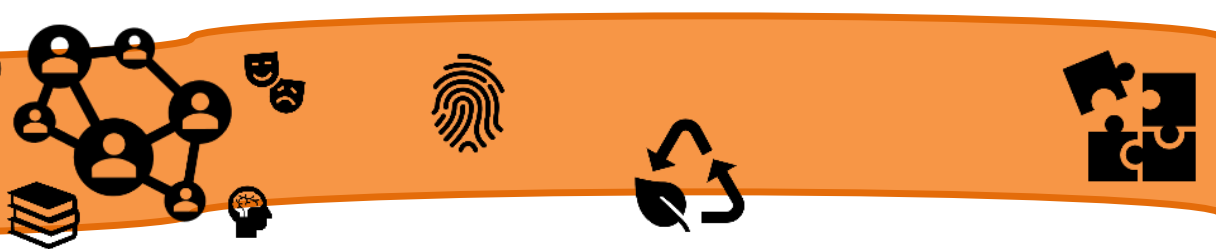

manifestações, ao invés de assistir aula. Entre os manifestantes está a amiga de Starr: Hailey, que sente pena pelo assédio que o policial está sofrendo, afinal ele agia em legítima defesa. Não há uma sensibilização por parte dos estudantes que são todos brancos, porque não há um olhar que enxerga os marcadores que atingem e oprimem Starr e seu amigo, pois não é a diferença deles.

Pensar com a sociologia seria sensibilizar-se com a diferença que não é necessariamente sua, entendendo as marcas que a conjuntura social, histórica, cultural atinge o indivíduo. Hailey personifica o preconceito tão enraizado em nossa sociedade que se torna invisível aos olhos de quem o pratica. Quando Starr a acusa de ter uma postura racista, a personagem se revolta e elas brigam. Pois, como ela pode ser racista se uma de suas melhores amigas é negra? É aí que entra a crítica, Starr não é “temida” pois suas atitudes são controladas para se encaixar no padrão da Escola Williamson. Isso nos faz refletir que ter amigos negros não inibe ninguém de ser preconceituoso. A obra aborda um preconceito velado, ou seja, pacífico, que não necessariamente tem agressão física.

O Chirs, namorado de Starr, em um discurso que para ele era "apoiador", diz que não enxerga a negritude de sua namorada, que para ele não existe diferença entre as raças, todos são iguais. É importante ressaltar a atitude de Starr quanto a esse comentário, pois afirma que se sua negritude não é vista, ele não a enxerga. Isso nos faz pensar que essa visão de "zero diferença" só é do privilegiado, pois apenas quem vive a realidade de ser "diferente" sabe que esse discurso diverge na prática. A “igualdade", nessa abordagem, pressupõe uma exclusão de quem se é, mas em seu real sentido, deve permitir o negro ser negro, com sua cultura e história.

Após a morte de seu amigo, Starr percebe que não pode se calar em meio à violência que cerca e afeta as pessoas negras. Com a ajuda da família e da advogada, April Ofrah (defende os direitos dos negros), passa a se manifestar contra o racismo institucional. $\mathrm{O}$ ativismo se destaca em suas atitudes, tanto pelas manifestações públicas, quanto por algumas atitudes "racistas-passivas" dos seus colegas que passam a ser intoleráveis. A postura da personagem revela o que pode ser um primeiro passo pra sanar essas questões, ou seja, ao entender que há marcadores da diferença e que precisam ser vistos numa visão de interseccionalidade, compreendemos que é preciso reivindicar os direitos nessa perspectiva da teoria interseccional. O preconceito não é 
isolado, não é apenas racial ou de gênero ou de classe. Não é “ou”, sim "e". Estes ocorrem conjuntamente.

Antes de morrer, Khalil e Starr estão ouvindo Tupac, um rapper americano que fez sucesso com seu ativismo nas décadas de 80 e 90. Ele canta Thug life (vida bandida) e Khalil explica a Starr que Thug life é a abreviação de "The hate u give little infants fucks everybody", ou "O ódio que você passa para as criancinhas fode com todo mundo". (http://www.blogdaeditorarecord.com.br/2017/07/24/o-odio-que-voce-semeiade- angie-thomas/)

\section{ANÁLISE NO CONTEXTO BRASILEIRO}

Não é apenas ficção, o filme remete a um ódio que é disseminado entre nós. Para reforçar o quão grande é o número de marcadores e como o preconceito que foi semeado nas gerações passadas, é repercutido pelas crianças daquela época e que ainda dá fruto em uma sociedade do século XXI - na qual os discursos são marcados por palavras como empatia, equidade, igualdade, direitos, entre outras -, traremos manchetes de dois casos semelhantes ao utilizado para essa análise, são fatos que aconteceram no Brasil só neste ano de 2019:

- “Na Zona Norte do Rio de Janeiro, o carro de uma família foi alvejado por militares com mais de 80 tiros de fuzil. Os militares disseram que o veículo da família foi confundido com o carro de fuga de assaltantes, mas de acordo com as testemunhas não tinham atividades estranhas no local." (https://movimentorevista.com.br/2019/04/oitenta- tiros-de-alerta/).

- "Polícia confunde guarda-chuva com fuzil e atira e mata um jovem negro" (https://www.geledes.org.br/policia-confunde-guarda-chuva-com-fuzil-e-atira-emata-um-jovem- negro/) .

- "PM confunde guarda-chuva com fuzil e mata garçom no Rio, afirmam testemunhas. Rodrigo Alexandre da Silva Serrano esperava a família chegar quando levou três tiros"

- "Meu filho de quatro anos já sabe o que é tiroteio. Que realidade é essa? A creche dele já foi alvejada várias vezes. Ele sabe o que é agachar, ficar escondido. Um menino de quatro anos já tem essa noção do que acontece dentro $d a$

comunidade" 

AGUIAR, mônica s.d. Tem gente que finge que isto não é realidade. "vidas negras importam. Disponivel em: <https://africas.com.br/tem-gente-que-finge-que-isto-nao-erealidade-vidas-negras-importam/)>. Acesso em: 13/04/2020.

BAUMAN, Zygmunt; MAY, Tim. Aprendendo a pensar com a sociologia. Rio de Janeiro: Zahar, 2010

HARAWAY, D. “Gênero" para um dicionário marxista:a política sexual de uma palavra. Cadernos Pagu(22), 2004.

LARAIA, R.B. Cultura, um conceito antropológico. Rio de Janeiro: Jorge Zahar, 2004

MELLO,L; GONÇALVES, E. Diferença e interseccionalidade: notas para pensar práticas em saúde. Revista Cronos, v.11, n. 2, 28. Nov. 2012

THOMAS, Angie. O ódio que você semeia. Rio de Janeiro: Ed. Galera, 2017 



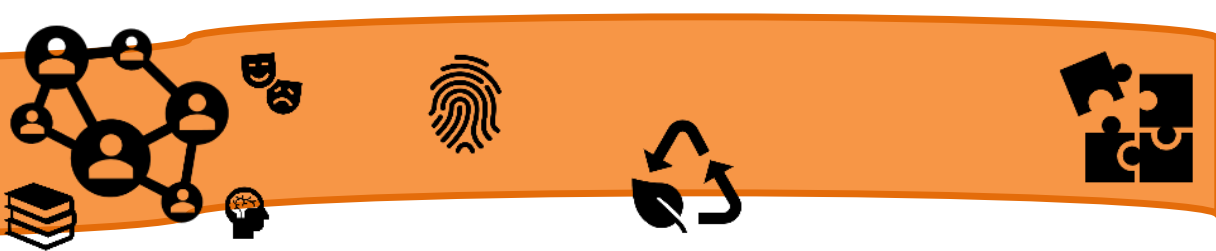

do homem, o permitiu a habilidade de sistematizar diferentes níveis de conhecimento que são adquiridos no decorrer de sua existência.

O ensino de Geografia está fundeado como uma ciência que visa o estudo de fenômenos e transformações que ocorrem no interior e na superfície do planeta, como as movimentações das placas tectônicas, tremores, distribuição espacial da população, a relação homem e natureza etc. o professor ao trabalhá-la, em sala de aula e enquanto ciência, deve abordar temas relacionados ao cotidiano dos alunos, envolvendo os entendimentos, a priori, de região, paisagem, lugar, espaço, tempo entre outros. Pois, como nos apontam os Parâmetros Curriculares Nacionais,

É imprescindível o convívio do professor com o aluno em sala de aula, no momento em que pretender desenvolver algum pensamento crítico da realidade por meio da Geografia. É fundamental que a vivência do aluno seja valorizada e que ele possa perceber que a Geografia faz parte do seu cotidiano, trazendo para o interior da sala de aula, com a ajuda do professor, a sua experiência. Para tanto, o estudo da sociedade e da natureza deve ser realizado de forma interativa. No ensino, professores e alunos poderão procurar entender que tanto a sociedade como a natureza constituem os fundamentos com os quais paisagem, território, lugar e região são construídos. (BRASIL, 1998, p. 30).

Com isso, o presente projeto consiste na utilização do gênero discursivo charge como um recurso didático-pedagógico que irá auxiliar o professor no processo de ensino e aprendizagem na disciplina de Geografia já que as charges são recheadas de informações que são obtidas por meio da leitura de forma verbal e não verbal.

Assim sendo, acreditamos, pois, contribuir na discussão sobre o processo de ensino aprendizagem do componente curricular de Geografia na perspectiva de trabalho com os gêneros discursivos, mais especificamente a charge.

\section{O ENSINO-APRENDIZAGEM DE GEOGRAFIA E OS GÊNEROS TEXTUAIS}

A partir deste ponto, trataremos do referencial teórico que subsidia a pesquisa. Inicialmente, apresentamos um panorama geral sobre o ensino de Geografia, os conceitos de gêneros textuais e abordamos as características do gênero textual charge e seus efeitos de sentido.

\section{O ensino-aprendizagem do componente curricular de Geografia}

O ensino-aprendizagem de Geografia passa por transformações constantemente. Sendo um componente curricular da área de ciências humanas é considerada de grande relevância para 


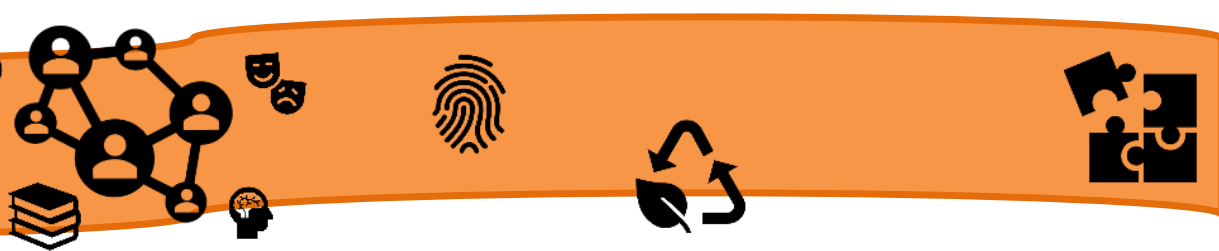

a formação crítica do cidadão. O professor, enquanto intermediário do processo de ensino e aprendizagem deve assumir um papel inovador baseado na sua formação que deve ser sólida e contínua. Ratificamos esse pensar conforme nos coloca Vesentini,

Um ensino critico não consiste pura e simplesmente em reproduzir num outro nível o conteúdo da(s) geografia(s) critica(s) acadêmica(s); pelo contrario, o conhecimento acadêmica ou cientifico deve ser reatualizado, reelaborado em função da realidade do aluno e do seu meio (...) não se trata nem de partir do nada e nem de simplesmente aplicar no ensino o saber cientifico; deve haver uma relação dialética entre esse saber e a realidade do aluno- daí o professor não ser um mero reprodutor mas um criador. (VESENTINI, 2003, p. 78).

Diante do exposto, o ensino de Geografia precisa ser constantemente ressignificado, levando o aluno a compreender o seu espaço. Sendo uma disciplina considerada estratégica, ela não deve ser entendida apenas como formadora do cidadão e sim para fazer o mesmo entender o seu meio e o mundo como um todo, pois a Geografia “[...] tem procurado pensar seu papel nessa sociedade em mudança, indicando novos conteúdos, reafirmando outros, reatualizando alguns outros [...]" (CAVALCANTI, 2002, p.11).

Assim, o ensino escolar "é um processo que contém componentes fundamentais e entre eles há de se destacar os objetivos, os conteúdos e os métodos (CAVALCANTI, 2002, p. 12)”. A escola tem, como um dos seus objetivos, a formação de valores, respeitando as diferenças, combatendo as desigualdades como também a injustiça social, esses também são objetivos da disciplina de Geografia.

\section{Os Gêneros Textuais}

Muitas pesquisas têm se preocupado em descrever a diversidade de gêneros textuais e em fazer sugestões didáticas para a realização de trabalhos diversos em sala de aula. Apesar dessas importantes contribuições, a prática pedagógica, no que se refere aos aspectos do ensino de língua materna, parece ainda não ter alcançado melhorias que proporcionem um avanço significativo na referida área.

Travaglia (2002, p. 18) afirma que "propiciar o contato do aluno com a maior variedade possível de situações de interação comunicativa por meio de um trabalho de análise e produção de enunciados", propicia o desenvolvimento da competência comunicativa dos usuários da língua, ou seja, a capacidade do usuário de empregar adequadamente a língua nas diversas situações de comunicação. Ao detalhar a situação em questão, o mesmo autor cita que:

[...] se a comunicação acontece sempre por meio de textos, pode-se dizer que, se o objetivo de ensino de língua materna é desenvolver a 


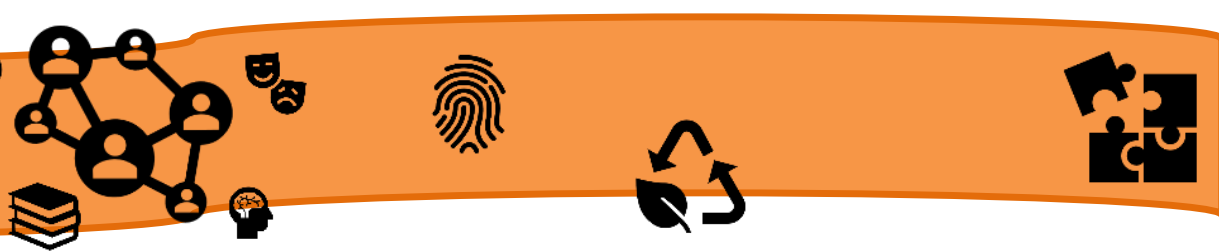

competência comunicativa, isto corresponde então a desenvolver a capacidade de produzir e compreender textos nas mais diversas situações de comunicação. (TRAVAGLIA, 2002, p. 19)

Daí se conclui a relevância para o ensino de uma teoria que trata especificamente do texto e o vê como um espaço que é o resultado da interação entre os sujeitos da linguagem que atuam em determinadas situações de comunicação para atingirem determinados objetivos

Torna-se impossível de se haver a comunicação verbal sem que seja feita a utilização de um dado gênero textual, como se torna impraticável a comunicação verbal sem utilizarmos um texto, pois como nos lembram Santos, Mendonça e Cavalcante (2008, p. 29):

Nas práticas de uso da língua todos os textos se organizam como gêneros textuais típicos, que usamos para contextos determinados social e historicamente, a partir das estratégias interativas construídas na sociedade em que estamos inseridos (CAVALCANTE, 2008, p. 29).

Sendo assim, esta visão segue a ideia de língua como sendo uma atividade social, cognitiva e histórica, em que podemos ver o privilégio para a natureza funcional e interpretativa. Partindo desse princípio, podemos frisar que existe uma dada diferença entre tipo de texto e gênero textual, que apresentaremos aqui, mostrando que, apesar de serem considerados e conceituados diferentemente, um só irá existir atrelado ao outro, pois cada tipo de texto configurar-se de um gênero e cada gênero configurará de um tipo de texto sendo que um gênero textual poderá conter mais de um tipo de texto porém, um irá se sobressair do outro, apresentando uma gama maior de características de um dos tipos apresentados neste referido gênero.

Segundo Marcuschi (2003), podemos entender o tipo textual como uma espécie de sequência teoricamente definida pela natureza linguística de sua composição como os aspectos lexicais, sintáticos, tempos verbais, relações lógicas e outras. A isso podemos acrescentar o fato de que esses tipos de texto abrangem-se em cinco: descritivo, dissertativo, injuntivo, narrativo e argumentativo; os quais são considerados de construções teóricas por propriedades linguísticas intrínsecas que se constituem de sequências linguísticas ou de enunciados no interior dos gêneros, sendo eles textos empíricos, ou seja, baseados na experiência e sem caráter científico (BAKHTIN, 1997; FÁVERO \& KOCH, 1987; MARCUSCHI, 2002; TRAVAGLIA, 1991).

No que se refere à conceituação de gêneros discursivos, Bakhtin $(1997$, p. 26) enfatiza que: "Os gêneros são modelos comunicativos e servem, muitas vezes para criar uma expectativa no interlocutor e prepará-lo para determinada reação. Operam prospectivamente, abrindo o caminho da compreensão". 


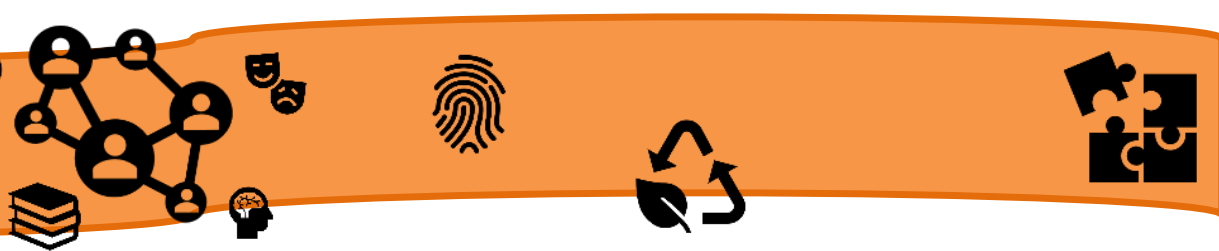

Diante do exposto, podemos agora dizer que os Gêneros Textuais são realizações linguísticas concretas definidas por propriedades sociocomunicativas, são textos encontrados em nosso cotidiano, são modelos adaptados às diversas situações comunicativas, interações. Preferindo-se aos textos materializados que encontramos em nossa vida diária e que apresentam características definidas por conteúdos, propriedades funcionais, estilo e composição.

\section{O Gênero Textual Charge}

O discurso chargístico explicita uma crítica à realidade social e política, ou não. Sendo elemento do meio jornalístico e confeccionado com traços de humor, gozador, crítico, sem que seja, entretanto, diretamente ofensiva, a charge (do francês charger: carregar, exagerar) tem como objetivo criticar um fato específico e, no geral, volta-se para a natureza política.

Enquanto gênero textual, a charge é possuidora de grandes riquezas que podem ser bem trabalhadas e ao mesmo tempo exploradas em sala de aula. Envolta principalmente no humor, a charge apresenta, em suas entrelinhas, uma imagem do cotidiano, da vida social, evocando discussões sobre os valores e crenças de seu leitor, bem como da própria sociedade como um todo.

A charge configura-se de elementos verbais e não verbais que irão, por algumas vezes, apresentar-se apenas com a linguagem não verbal. Esse gênero por sua vez, exige que o leitor tenha um breve conhecimento daquilo que está sendo retratado, uma vez que é repleta de sentidos e, assim, necessita de uma leitura para o seu visual.

O gênero textual charge é utilizado, em sua maioria, para expressar os fatos e os acontecimentos da atualidade com caráter cômico e crítico ao mesmo tempo. Partindo desses pontos de vistas, podemos considerar as charges como sendo parte integrante da atualidade e como possuidoras de um importante recurso que pode ser utilizado em sala de aula, envolvendo atividades voltadas para a leitura e a produção da escrita, buscando sempre a interpretação do texto, sendo um manancial pleno de múltiplas informações.

O estudo do gênero textual charge é, portanto, muito interessante, valendo ressaltar que o leitor deve ser possuidor de conhecimentos prévios sobre o tema que está sendo explorado pela charge, lembrando ainda que esses temas sempre são atuais.

Como já apontam Souza e Machado:

[...] é comum a charge apoiar-se apenas no desenho para a emissão de um sentido. No entanto, há charges que também apresentam o texto verbal, e esse conteúdo verbal refere-se tanto às palavras propriamente ditas quanto tão somente à presença de sinais de pontuação. $\mathrm{O}$ texto chargístico geralmente é escrito à mão e isso, obviamente, propicia ao produtor maior poder de representação figurativa, pois o sentido da 


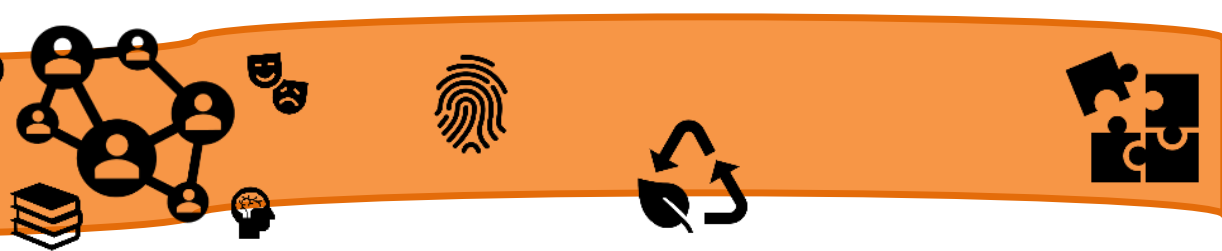

mensagem pode ser reforçado e melhor atingido pelo próprio traçado das letras (SOUZA e MACHADO, 2005, p. 62).

Diante do exposto, compreendemos que o gênero textual charge ainda é pouco explorado em trabalhos acadêmicos, daí a importância de ser realizada essa pesquisa, que será de grande relevância para a academia, servindo de base para demais estudos. É importante também para a sociedade, pois ela está diretamente envolvida no processo de formulação de cada charge e seu discurso, bem como esta se põe enquanto importante referencial sobre como as relações sociais se estabelecem, especialmente quanto ao aspecto da conjuntura do cenário político.

Além disso, podemos conceber a charge como um gênero textual que traz como característica marcante o humor, mas, posteriormente, ela pode provocar ironia, contestação, crítica e denúncia ou tecer comentários prós ou contras.

[...] o traço caracterizador da charge é a polifonia que permite perceber um jogo de vozes contrastantes provocador do riso, assumindo, assim, o estatuto de texto humorístico. [...] ao fornecer as informações e o suporte contextual para o seu entendimento, seja conduzindo para uma direção convergente de sentidos, portanto parafrástica, seja numa direção divergente, parodística. Outro ponto importante a ser observado na charge é o fato de que, na sua construção interna, ela é bivocal, porque é carnavalesca, no sentido bakhtiniano. Ela informa e opina sobre o seu tema por meio da representação de um "mundo às avessas", aguçando, pela própria inversão de valores sociais que promove uma visão mais nítida da realidade. $\mathrm{O}$ autor da charge cumpre um ritual ambivalente, porque conjuga elementos díspares, ao figurar a autoridade e destroná-la e ao apontar a ordem instituída pelo reverso de sua aparência séria. (GURGEL 2003, p. 33)

Podemos dizer que uma particularidade forte e marcante dos textos repassados no gênero textual charge é o caráter de ser fortemente crítico, em que determinados momentos ela assume ideias semelhantes e em outros as ideias passam a ser diferentes.

Em outras características encontradas neste gênero textual, pode-se citar o acontecimento do dia, sendo assim, a situação de diálogo entre a realidade e o novo, retratando uma notícia que possui vida curta devido à rapidez dos meios de comunicação em estar sempre atualizando os acontecimentos. A charge possui sua vida útil curtíssima. Esse fato de retratar fatos do cotidiano, do novo, da atualidade faz com que a charge se diferencie de outros gêneros textuais que se utiliza de imagens, nas modalidades verbais e não verbais como são os casos do cartum e da tirinha. 



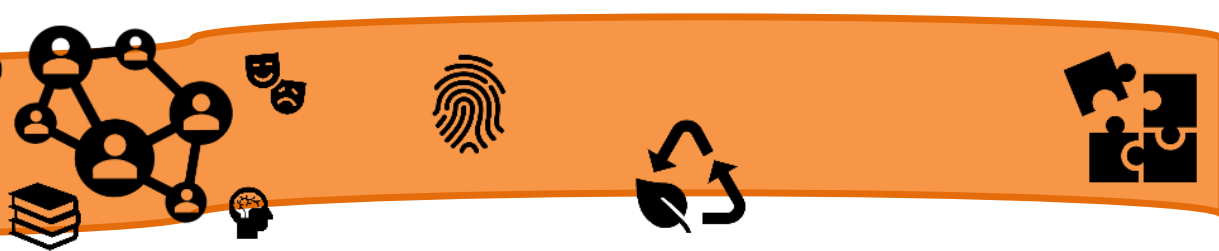

bem informado acerca do tema abordado para que possa compreender e captar o seu teor crítico e cômico.

\title{
METODOLOGIA/ANÁLISE
}

Do ponto de vista de sua natureza, este trabalho pode ser classificado como uma pesquisa de cunho exploratório já que o mesmo tem por finalidade esclarecer o leitor acerca de conceitos já criados, dando-o assim, a oportunidade de modificá-los. Pois, como nos aponta Gil (2008, p. 46)

\begin{abstract}
As pesquisas exploratórias têm como principal finalidade desenvolver, esclarecer e modificar conceitos e ideias, tendo em vista a formulação de problemas mais precisos ou hipóteses pesquisáveis para estudos posteriores. De todos os tipos de pesquisa, estas são as que apresentam menor rigidez no planejamento. Habitualmente envolvem levantamento bibliográfico e documental, entrevistas não padronizadas e estudos de caso. Procedimentos de amostragem e técnicas quantitativas de coleta de dados não são costumeiramente aplicados nestas pesquisas. (GIL, 2008, p. 46).
\end{abstract}

No que concerne a metodologia desta pesquisa, utilizamos a bibliográfica, que trata acerca da análise de literatura já publicada. Esse tipo de pesquisa nos fornece informações sobre a temática a ser trabalhada, temos também a oportunidade de conhecer opiniões idênticas e desiguais acerca do tema em foco. Ratificamos esse pensar ao comungarmos com Gil (2008, p. 50), ao afirmar que:

A pesquisa bibliográfica é desenvolvida a partir de material já elaborado, constituído principalmente de livros e artigos científicos. Embora em quase todos os estudos seja exigido algum tipo de trabalho desta natureza, há pesquisas desenvolvidas exclusivamente a partir de fontes bibliográficas. Parte dos estudos exploratórios podem ser definidos como pesquisas bibliográficas, assim como certo número de pesquisas desenvolvidas a partir da técnica de análise de conteúdo. (GIL, 2008 p. 50)

O objetivo de investigação desta pesquisa parte das produções de 25 (vinte e cinco) alunos do $9^{\circ}$ ano da Escola Municipal Padre José Luiz Silva - Pendências/RN, que para o corpus da pesquisa utilizaremos apenas 04 (quatro) que foram obtidas por meio da aplicação de uma atividade, que consistia em analisar charges voltadas para a temática ambiental. Essa atividade foi aplicada junto com o professor da disciplina de Geografia da aludida escola.

Iniciamos com uma aula expositiva acerca de tipos de texto e gêneros discursivos para nortear os alunos sobre as diferenças existentes entre eles. Após essa breve introdução, trabalhamos exclusivamente o gênero discursivo charge. 


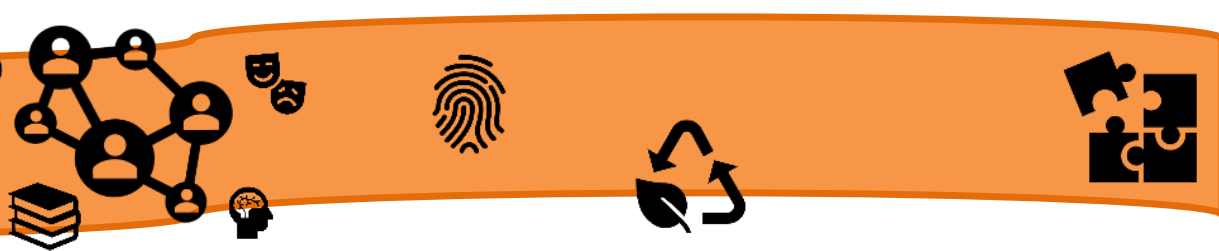

Enquanto procedimento metodológico da pesquisa, o professor abriu discussões acerca de tipos e gêneros textuais. Assim, foi explicitado de maneira expositiva que os tipos de textos podem ser: dissertativo, argumentativo, injuntivo/instrucional, narrativo e/ou descritivo. Eles são finitos. Com o mesmo procedimento, o professor explicou acerca dos gêneros textuais que são as estruturas compositoras dos textos podendo ser orais ou escritos. Esses gêneros textuais são infinitos e não podemos estudar todos eles e assim, mais precisamente, tratamos sobre as características do gênero textual charge em sua estrutura e efeitos de sentido.

Com o término dessa parte inicial, distribuímos, de maneira aleatória, uma charge para cada aluno em sala (existiam duas de cada). Foi solicitado que cada aluno descrevesse, oralmente, quais as informações a charge recebida repassavam para ele enquanto leitor e qual o efeito de sentido transmitido por ela. Na sequência, foi solicitado que cada aluno escrevesse um texto, transcrevendo o entendimento obtido por meio da leitura da referida charge.

Como forma de mediação da atividade, interagimos com os alunos como forma de esclarecer as dúvidas que poderiam ir surgindo ao longo da realização da atividade. Ao término dessa parte individual, houve uma ação coletiva em que os alunos puderam expor, novamente, suas opiniões de forma oral, já que a escrita havia sido concluída.

\section{Analisando as charges trabalhadas em sala de aula.}

A atividade foi concluída com bastante êxito devido ao interesse apresentado pelos alunos, haja vista que o tema abordado pelas charges e os efeitos de sentido das mesmas são bastante atuais. Segundo Agostinho (1993, p. 229) “A charge se constitui realidade inquestionável no universo da comunicação, dentro do qual não pretende apenas distrair, mas, ao contrário, alertar, denunciar, coibir e levar à reflexão". Assim, os alunos expuseram suas opiniões acerca do que foi observado em cada charge analisada. Cada leitor teve a liberdade de expor suas interpretações.

Assim, as atividades que foram desenvolvidas pelos alunos em questão tiveram como um dos objetivos o desenvolvimento das competências: interpretativa e crítica por meio da análise das charges. Apresentaremos a seguir, as charges e os pontos de vistas dos alunos que iremos intitular de Aluno 01 (A-1); Aluno 02 (A-2); Alunos 03 (A-3); e Aluno 04 (A-4), por meio do conteúdo já apresentado. 


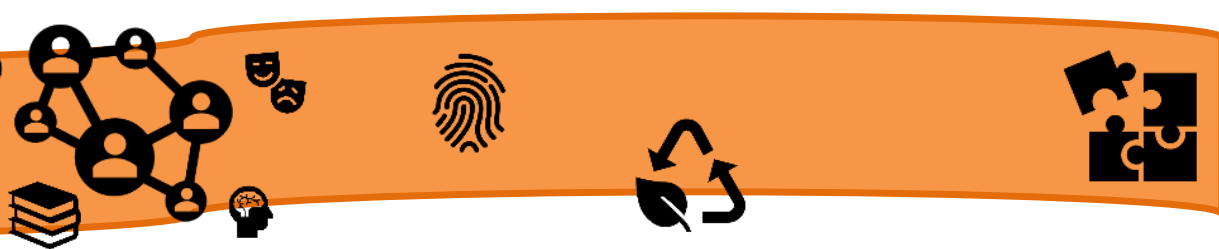

\begin{tabular}{|c|c|}
\hline Charge 1 & Charge 2 \\
\hline $\begin{array}{l}\text { Disponível em: } \\
\text { http://aws.jornaldebrasilia.com.br/charges/ } \\
\text { 155/clima-seco-do-inverno-brasiliense/ } \\
\text { Acesso em: } 26 / 10 / 2016\end{array}$ & $\begin{array}{l}\text { Disponível em: } \\
\text { http://humortadela.bol.uol.com.br/charges/48374 } \\
\text { Acesso em 26/10/2016. }\end{array}$ \\
\hline Charge 3 & 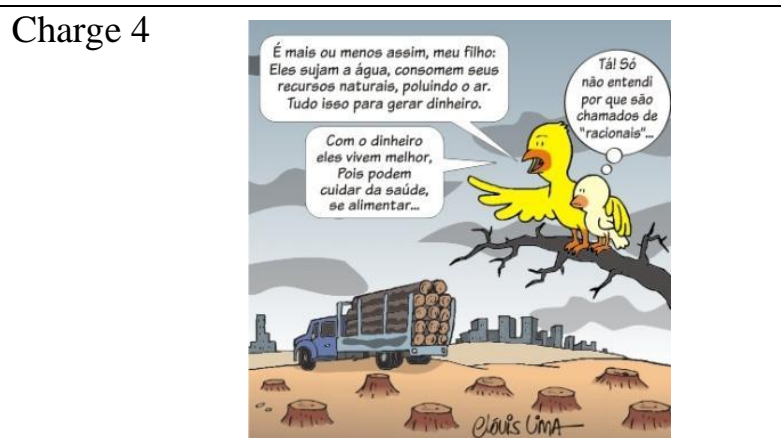 \\
\hline $\begin{array}{l}\text { Disponível em: } \\
\text { http://formulageo.blogspot.com.br/2013/01/alteracao } \\
\text {-em-micro-clima-desmatamento.html Acesso em: } \\
26 / 10 / 2016 .\end{array}$ & $\begin{array}{l}\text { Disponível em: } \\
\text { http://andergeo2012.blogspot.com.br/2013/07/desmatamento } \\
\text {-em-charges.html Acesso em: 26/10/2016. }\end{array}$ \\
\hline
\end{tabular}

No que concerne a charge 1, percebemos que esta enfatiza as questões inerentes ao calor excessivo na cidade de Brasília localizada na região Centro-oeste do nosso país. A charge apresenta um camelo, animal típico de áreas desérticas do planeta que tem por característica calor excessivo durante o dia e áreas restritas com água. Nesse caso, a charge ironiza a questão do calor e secura em Brasília, algo que nem o camelo que é típico de regiões com essas características está suportando e assim, imaginemos então a população. Um dos alunos que analisou as charges obteve o seguinte entendimento:

Por conta do desmatamento nas grandes cidades, para a construção de prédios, o calor aumenta a ponto de um camelo que vive no deserto, que é muito quente, não suportar o calor. $\mathrm{O}$ camelo da intenção de exagero, que o calor é muito grande. A cada dia que passa o calor aumenta mais e mais. Os rachões no chão parece faltar água, uma crise hídrica (A-1).

A charge 2, por sua vez, retrata a previsão do tempo que nos possibilita um planejamento no momento de sair de casa, porém, no caso explicitado na charge compreende a 


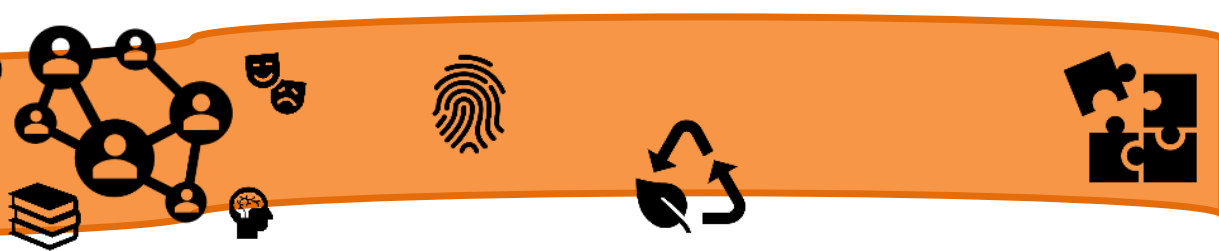

uma previsão bastante mista em que não conseguiremos nos organizar bem, haja vista que em um mesmo dia o tempo mudará constantemente. Na análise do aluno, observamos o seguinte:

Essa charge mostra uma repórter passando a previsão do tempo. Um tempo muito misto e descontrolado, mesmo tendo tempestades de chuva, logo após faz sol. Que pena que essa previsão é só para São Paulo, pois aqui no Nordeste só faz sol (A-2).

Podemos, ainda, perceber na análise acima que o aluno faz uma comparação com o clima de São Paulo com o clima da região Nordeste desejando até que essa inconsistência do clima/tempo fosse nessa região já que por aqui apenas o sol predomina e nos falta a chuva.

No tocante à charge 3 , percebemos que esta apresenta um cenário bastante comum na floresta amazônica que é justamente o desmatamento. Este desmatamento, por sua vez, trás uma série de prejuízos ao meio ambiente e a população como um todo. A análise do aluno (A-3) retrata o seguinte:

\begin{abstract}
A imagem (charge) tá mostrando um homem, que depois de ter desmatado todas as árvores se pergunta porque o motivo do calor e é bem simples a resposta porque as árvores não e para ser derrubadas e sim para ser cultivadas para elas, nós dar sombras e frutas no futuro porisso temos que cultivar todas as árvores para depois agente não tar se lamentando e se preguntando o porque o motivo do calor se sabemos que o motivo somos nois. Porque para toda ação tem uma reação $(\mathrm{A}-3)$
\end{abstract}

Para finalizar as análises, chegamos a charge 4, que mostra um cenário parecido com o da charge 3: um desmatamento. Na charge 4, existe um diálogo entre dois pássaros (pai e filho). O pai relata ao filho que o ser humano destrói, de diversas formas, o meio ambiente como forma de gerar dinheiro. O pai completa sua fala informando que com o dinheiro ganho com a derrubada das árvores, eles conseguem cuidar da saúde e alimentar-se, eles são seres racionais e não raciocinam. O pássaro filho finaliza a charge dizendo "só não entende porque eles são chamados de racionais". A interpretação do aluno (A-4) é a seguinte:

Podemos observar na charge acima seres humanos que acabaram de extrair uma floresta inteira, o recurso que nos beneficiam bastante, nos da sombra e combate o aquecimento global, pois produz oxigênio para todos os seres vivo e tirando esses recursos da natureza os seres humanos não só se prejudicam a si mesmos más a sua alimentação e sua moradia tirando esse animais de seu conforto, proveniente muitos animais entraram em extinção em pouco tempo (A-4).

Ao finalizar as análises realizadas pelos alunos, reiteramos aqui uma maior utilização em sala de aula desse gênero textual, haja vista, diante do que já se foi exposto, que o mesmo é 


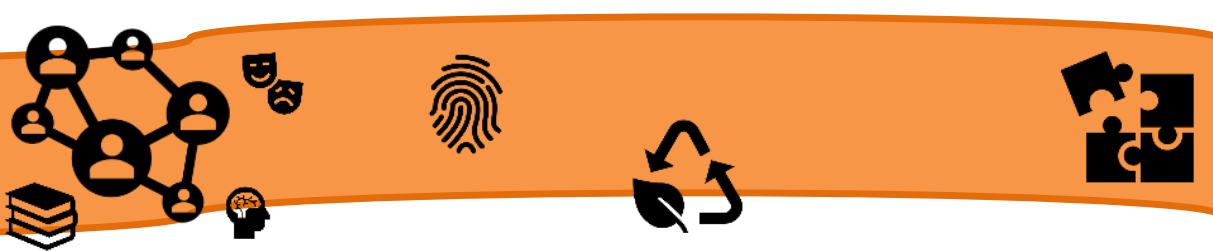

cheio de sentidos e significados, dessa forma, muito rico e propício para ser trabalhado em sala de aula.

\section{CONSIDERAÇÕES FINAIS}

Existe uma infinidade de gêneros textuais e essa infinidade representa às nossas necessidades de interação comunicativa como o meio social. Essa necessidade de interação é realizada através da língua que por sua vez pode ser oral ou escrita. Nesse contexto, ao utilizarmos um gênero textual em sala de aula devemos conhecer sua real funcionalidade no contexto social e comunicativo.

Assim, todo gênero textual tem a sua funcionalidade social no dia a dia. Falando especificamente em sala de aula e nas aulas de Geografia, as charges devem ser vistas como um recurso atrativo e rico para ser explorado tanto pelo professor quanto pelo aluno, pois pode ser trabalhado a leitura de textos escritos e a leitura de imagem aumentou assim a capacidade de interpretação e comunicação dos alunos.

As charges, por serem possuidoras de características humorísticas, irônicas e carregadas de críticas, transcrevem uma visão inteligente da realidade, promovendo uma interpretação crítica e gozadora acerca dos problemas vigentes na atual sociedade. Assim, acabam despertando e desenvolvendo nos alunos uma maior capacidade de interpretação por meio de seus elementos.

No tocante ao componente curricular de Geografia, percebemos que a quantidade e a qualidade do gênero textual charge relacionado aos temas relacionados ao meio ambiente, política, migrações e demais conteúdos trabalhados em sala de aula. Percebemos, com esse trabalho, que os alunos em ênfase, apresentam uma considerável compreensão desse gênero textual, pois apresentaram em seus textos (orais e escritos) informações coerentes com o que estava sendo apresentado nas charges estudadas.

Assim, concluímos este trabalho ressaltando que o gênero textual charge é possuidor de grandes riquezas e informações ao trabalhar fatos e acontecimentos retratados e apresentados por ela. Por isso, acreditamos que o referido gênero deve ter uma maior representação nos livros didáticos como acontece com as tirinhas e os cartuns, pois percebemos que uma única charge é possuidora de relevantes interpretações e entendimentos que podem levar os alunos a uma melhor produção textual após sua leitura visual e verbal.

Diante da experiência que tivemos e da vivência permitida pelo presente estudo, percebemos que a aplicabilidade do gênero textual charge como recurso didático-metodológico no processo de ensino-aprendizagem do componente curricular de Geografia é uma realidade possível. 


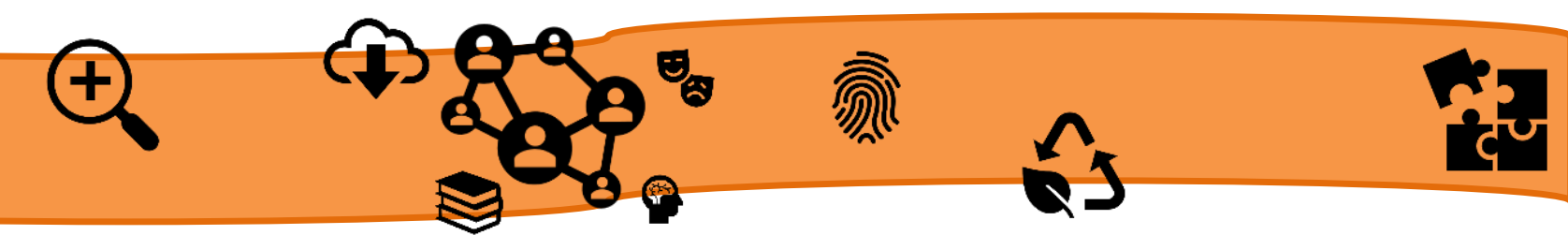

\section{REFERÊNCIAS}

AGOSTINHO, Aucione Torres. A charge. 1993. 330 f. Tese (Doutorado em Comunicação) - Escola de Comunicações e Artes, Universidade de São Paulo, São Paulo, 1993.

BAKHTIN, Mikhail. Estética da criação verbal. São Paulo: Martins Fontes, 1997.

BRASIL. Parâmetros Curriculares Nacionais (PCNs). Geografia. Ensino. Fundamental. Brasília: MEC/SEF, 1998.

CAVALCANTI, Lana de Souza. Geografia e prática de ensino. Goiânia: Alternativa, 2002.

CAVALCANTI, Maria Clara C. Multimodalidade e argumentação na charge.

Dissertação (Pós-graduação em Letras) - Universidade Federal de Pernambuco, 2008.

FÁVERO, L. L. \& KOCH, I. V. (1987). “Contribuição a uma tipologia textual”. In Letras \& Letras. Vol. 03, $\mathrm{n}^{\circ}$ 01. Uberlândia: Editora da Universidade Federal de Uberlândia.

Ferreira, Fernanda de Moura; Alves, Maria da Penha Casado. A CHARGE ENQUANTO GÊNERO DISCURSIVO NO ENSINO MÉDIO. Revista Ensino Interdisciplinar, v. 1, nº. 02, Setembro/2015 UERN, Mossoró, RN

GIL, Antonio Carlos. Métodos e técnicas de pesquisa social. - 6. ed. - São Paulo: Atlas, 2008.

GURGEL, Nair. A charge numa perspectiva discursiva. Primeira versão, Porto Velho, Departamento de Letras, UFRO, $\mathrm{n}^{\circ}$ 135, ano I, 2003. Disponível em: http://www.unir.br/ primeira/artigo135.html. Acesso em: 22 mai. 05.

MARCUSCHI, L. A. (2002). "Gêneros textuais: definição e funcionalidade" In DIONÍSIO, Â. et al. Gêneros textuais e ensino. Rio de Janeiro: Lucerna.

SOUZA, M.I.P. de O.; MACHADO, R. B. O verbal e o não verbal na produção de efeitos de sentidos no gênero charge. In: CRISTOVÃO, V. L. L.; NASCIMENTO, E. L. (Org.). Gêneros Textuais: teoria e prática II. Palmas e União da Vitória, PR: Kayangue, 2005, p. 59-71.

TRAVAGLIA, Luis Carlos. Gramática e interação: uma proposta para o ensino e gramática, 14 Ed. São Paulo: Cortez, 2009

TRAVAGLIA, L. C. (1991). Um estudo textual-discursivo do verbo no português. Campinas, Tese de Doutorado / IEL / UNICAMP, 1991. $330+124$ pp. 
VESENTINI, José Willian. Educação e ensino da geografia: instrumento de dominação e/ou de libertação. In: CARLOS, Ana Fani Alessandri. A geografia na sala de aula. 5 ed. São Paulo: Contexto, 2003. 



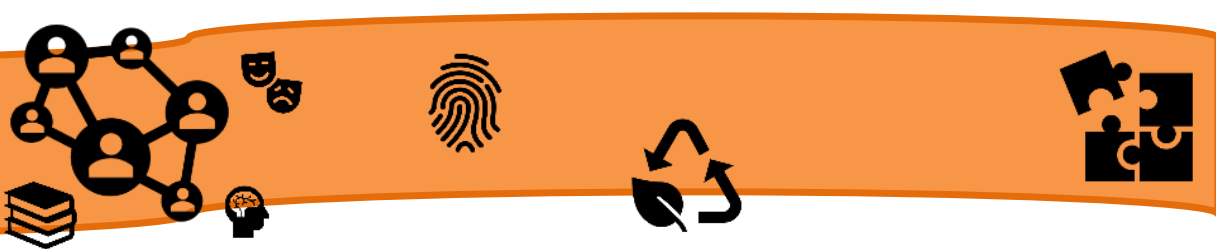

demandas locais de formação de mão-de-obra qualificada das regiões onde atua, formando recursos humanos competentes para intervirem no desenvolvimento local e regional. No Campus Avançado de Ponte Nova, lócus da pesquisa, são utilizados computadores, smartphones, tablets como ambientes educacionais para os alunos, que significam novas oportunidades de aprender por meio do uso de equipamentos de processamento de dados.

As redes sociais, os softwares educacionais e os aplicativos de mensagens são programas utilizados no auxílio da aprendizagem, pois ajudam no compartilhamento de informações e em trocas de mensagens de maneira on-line.

Mendes (2008) define recursos computacionais como um conjunto de recursos tecnológicos que, quando integrados entre si, proporcionam a automação e/ou a comunicação nos processos existentes nos negócios, no ensino e na pesquisa científica. São tecnologias usadas para reunir, distribuir e compartilhar informações.

A escolha da tecnologia está relacionada às propostas pedagógicas da escola e com o conteúdo que será trabalhado em sala de aula. As possibilidades de utilização das ferramentas tecnológicas, com todas as suas novas potencialidades e por meio da educação on-line, proporcionam oportunidades de aprendizagem (SANTOS; CRUZ; PAZZETTO, 2002).

Estas oportunidades de aprendizagem são: listar os conteúdos ministrados de maneira visual, interatividade durante as aulas expositivas e desafios que podem ser criados em grupos. Essas questões vivenciadas em sala de aula com o auxílio de recursos computacionais surgem da necessidade do dinamismo nas aulas de cunho teórico, para que o conteúdo ministrado seja repassado para o aluno de maneira mais consistente e objetiva.

Portanto, práticas educacionais e tecnologias são importantes na educação e, quando usadas de forma complementar, podem auxiliar na aplicação dos conteúdos ministrados em sala de aula e contribuem para o fortalecimento na interação, na comunicação e no trabalho cooperativo entre os professores, visto tratar-se de instrumentos para que desenvolvam um projeto educacional eficiente e estruturado.

\section{OBJETIVOS}

Os objetivos deste estudo são:

a) Analisar o uso de recursos computacionais por alunos de ensino técnico, do Instituto Federal de Minas Gerais - Campus Avançado de Ponte Nova em apoio ao conteúdo ministrado pelos professores, perante as respostas dos estudantes ao questionário aplicado em sala de aula;

b) Comparar os recursos computacionais utilizados na pesquisa, para o processo de ensino-aprendizagem no IFMG - Campus Avançado de Ponte Nova. 


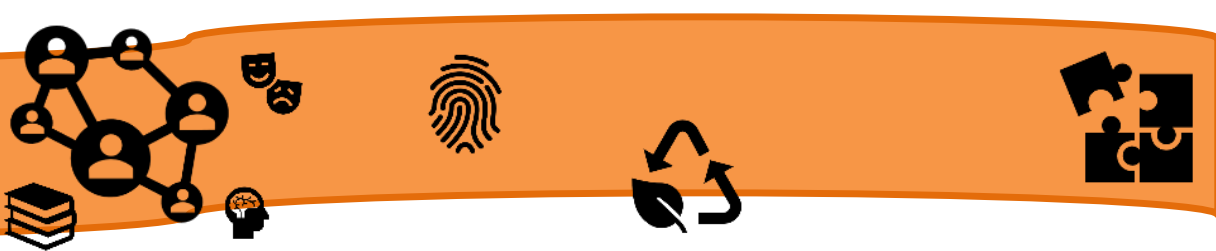

\section{METODOLOGIA}

A pesquisa teve como método o estudo de caso, uma vez que focalizou o processo educacional desenvolvido com a adoção de recursos computacionais no Instituto Federal de Minas Gerais (IFMG) - Campus Avançado de Ponte Nova. O estudo de caso, segundo Yin (2015, p. 58), “é uma investigação empírica de um fenômeno contemporâneo dentro do seu contexto da vida real, especialmente quando os limites entre o fenômeno e o contexto não estão claramente definidos".

O caráter da pesquisa é quantitativo. Segundo Lakatos e Marconi (2010):

A estratégia quantitativa possui dados estatísticos como centro do processo de análise de um problema. Quantificam-se opiniões, dados e outras informações. Esse método possui como diferencial a intenção de garantir a precisão de trabalhos realizados, conduzindo a um resultado com poucas chances de distorções (LAKATOS; MARCONI, 2010, p. 68).

Para a reunião dos dados, foi aplicado aos alunos um questionário composto por vinte questões fechadas relacionado ao emprego de recursos computacionais em apoio ao conteúdo ministrado na disciplina selecionada para estudo. Os dados coletados foram tratados por meio da análise estatística fatorial.

Os dados da pesquisa foram tratados no programa estatístico Predictive Analytics Software (PASW 18) e Minitab, versão 17. Em todos os testes estatísticos utilizados, foi considerado um nível de significância de 5\%. Dessa forma, são consideradas associações estatisticamente significativas aquelas cujo valor $p$ foi inferior a 0,05 (FISHER, 2004).

Responderam ao questionário duzentos e cinquenta alunos na disciplina de Introdução à Informática, do Ensino Médio/Técnico do Instituto Federal de Minas Gerais - Campus Avançado de Ponte Nova.

Os recursos tecnológicos utilizados em sala de aula e objetos de estudo foram:

a) A ferramenta de mensagem instantânea "WhatsApp";

b) O software de redes sociais "Facebook".

\section{ANÁLISE DOS DADOS E DISCUSSÃO DOS RESULTADOS}

$\mathrm{Na}$ análise quantitativa fatorial dos questionários fechados respondidos pelos discentes, precisou-se primeiramente realizar etapas de limpeza para iniciar-se a análise fatorial. Segundo Little e Rubin (2014, p. 39, tradução nossa), "se fazem necessárias etapas de limpeza, transformação e formatação dos dados por meio da análise de dados faltantes, missings e análise de pontos extremos". 


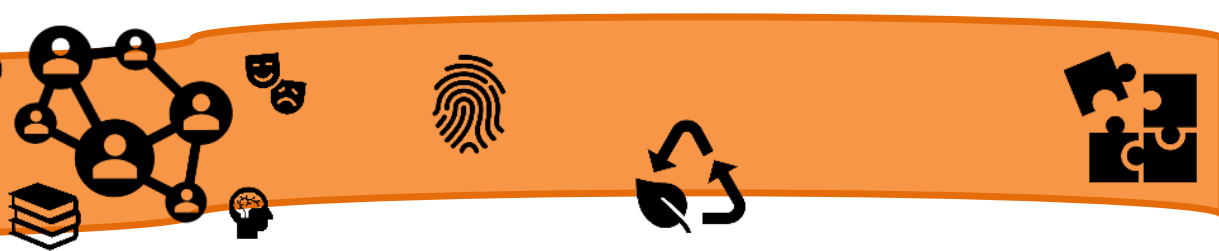

As etapas de limpeza foram feitas para verificar se houve erros de digitação, pois a planilha de Excel com os dados dos questionários podem conter estes erros ou dados podem ter faltados no preenchimento da planilha, então as etapas de limpeza são processos de correção ou exclusão dos dados. Para isto, utilizam-se o mínimo e o máximo em variáveis quantitativas para corrigir estes dados.

A análise dos dados foi feita por meio de estatística fatorial, realizada de forma exploratória, na apuração da análise estatística, usou-se a forma univariada. Segundo Reis (2009, p. 43) "na univariada utiliza-se a apuração de medidas de posição (média) e de dispersão (desvio padrão) para apresentar as questões relativas ao questionário".

Em seguida, foi aplicado o teste de Wilcoxon, indicado na comparação em duas situações do mesmo respondente, para detectar diferenças de opinião entre os recursos computacionais Facebook e WhatsApp.

A pesquisa possui uma população de 250 discentes de uma instituição de ensino técnico integrado ao ensino médio e ensino técnico subsequente. A população, em termos de tamanho, está distribuída da seguinte maneira:

- $\quad 40$ discentes cursando o $1^{\circ}$ ano de Administração - turma 1;

- 40 discentes cursando o $1^{\circ}$ ano de Administração - turma 2;

- 40 discentes cursando o $1^{\circ}$ ano de Informática - turma única;

- $\quad 40$ discentes cursando o $2^{\circ}$ ano de Informática - turma única;

- 45 discentes cursando o $1^{\circ}$ módulo de Informática - turma única;

- 45 discentes cursando o $2^{\circ}$ módulo de Administração - turma única.

Os questionários foram aplicados no período de 14 a 18 de maio de 2018 no laboratório de informática do Campus Avançado de Ponte Nova, para os discentes que participaram desta pesquisa. Um questionário foi elaborado pelo pesquisador com um total de 20 perguntas. Segundo Gil (2010), o questionário tem o objetivo de captar opiniões, crenças, sentimentos, interesses, expectativas e percepções dos respondentes de maneira uniformizada.

O Facebook e o WhatsApp possuem as mesmas perguntas no questionário, pelo fato de serem utilizados como aplicativos de interação/comunicação. A primeira ferramenta tecnológica é uma rede social e a segunda um aplicativo de troca de mensagens.

O questionário foi customizado, segundo o recurso computacional a ser utilizado antes da aplicação aos discentes. Foi utilizada a escala Likert, que atribui o valor de cinco pontos, com a seguinte classificação: 1 - Discordo totalmente; 2 - Discordo parcialmente; 3 - Nem concordo nem discordo; 4 - Concordo parcialmente; e 5 - Concordo plenamente.

\section{Características na análise estatística fatorial dos alunos}


Entre os alunos, em uma análise comparativa aos recursos Facebook e WhatsApp, verificou-se a existência de diferenças significativas quanto às perguntas 1, 2, 9, 10, 11, 12, 15 e 17, pois o teste apresentou um valor- $p$ de $0,000^{* *}$, o recurso WhatsApp foi o mais expressivo, ou seja, os respondentes tendem a concordar mais com o uso do WhatsApp do que o Facebook.

Esta concordância deve-se ao fato de que os valores de $p$-valor em negrito identificado na Tabela 1, indicam diferenças significativas entre o uso dos dois recursos computacionais usados na pesquisa. Os resultados significativos foram identificados com asteriscos, de acordo com o nível de significância, a saber: $p$-valor < $0.01 * *$ (nível de confiança de 99,0\%) e $p$-valor $<0.05^{*}$ (nível de confiança de 95,0\%). Para as perguntas 3, 7 e 8 , o recurso computacional Facebook apresentou maior concordância do que o WhatsApp.

Tabela 1. Distribuição referente aos recursos computacionais Facebook e WhatsApp

\begin{tabular}{|c|c|c|c|c|c|c|}
\hline \multirow{2}{*}{\multicolumn{2}{|c|}{ Perguntas }} & \multicolumn{2}{|c|}{ Facebook } & \multicolumn{2}{|c|}{ WhatsApp } & \multirow{2}{*}{$P$-valor } \\
\hline & & Média & D.P. & Média & D.P. & \\
\hline 1 & $\begin{array}{l}\text { O recurso computacional torna o aprendizado mais } \\
\text { interessante? }\end{array}$ & 4,60 &, 78 & 4,85 & ,49 & $0,000 * *$ \\
\hline 2 & $\begin{array}{l}\text { O recurso computacional desperta o interesse pelas } \\
\text { aulas? }\end{array}$ & 4,45 &, 94 & 4,78 &, 71 & $0,000 * *$ \\
\hline 3 & $\begin{array}{l}\text { Com o uso do recurso computacional, o processo de } \\
\text { aprendizagem foi mais dinâmico? }\end{array}$ & 4,79 &, 67 & 4,44 & ,60 & $0,000 * *$ \\
\hline 4 & $\begin{array}{l}\text { O recurso computacional contém recursos } \\
\text { motivacionais que despertam a atenção da disciplina } \\
\text { que está sendo ministrada? }\end{array}$ & 4,17 & 1,11 & 4,33 & ,78 & 0,059 \\
\hline 5 & $\begin{array}{l}\text { O recurso computacional permite ampliação do } \\
\text { conhecimento além do conteúdo ministrado em sala } \\
\text { de aula e/ou no laboratório de informática? }\end{array}$ & 4,44 & ,98 & 4,45 &, 72 & 0,890 \\
\hline 6 & $\begin{array}{l}\text { O recurso computacional oferece suporte de } \\
\text { comunicação e interação (chats)? }\end{array}$ & 4,90 &, 38 & 4,89 &, 37 & 0,717 \\
\hline 7 & $\begin{array}{l}\text { O recurso computacional oferece suporte de } \\
\text { compartilhamento de materiais educacionais } \\
\text { (arquivos)? }\end{array}$ & 4,96 &, 22 & 4,84 &, 50 & $0,000 * *$ \\
\hline 8 & $\begin{array}{l}\text { O recurso computacional oferece opção de fazer } \\
\text { download de arquivos (textos, áudios e vídeos)? }\end{array}$ & 4,89 &, 39 & 4,78 &, 51 & $0,002 * *$ \\
\hline 9 & $\begin{array}{l}\text { O recurso computacional oferece opção de registro } \\
\text { do histórico para pesquisas do conteúdo trabalhado } \\
\text { em sala de aula e/ou no laboratório de informática ser } \\
\text { consultados posteriormente? }\end{array}$ & 4,47 &, 76 & 4,84 &, 45 & $0,000 * *$ \\
\hline 10 & $\begin{array}{l}\text { O recurso computacional oferece ferramenta de } \\
\text { busca/pesquisa de determinado conteúdo? }\end{array}$ & 4,49 &, 76 & 4,68 &, 82 & $0,000 * *$ \\
\hline 11 & $\begin{array}{l}\text { Os conhecimentos adquiridos por meio do recurso } \\
\text { computacional possuem alguma aplicabilidade } \\
\text { prática no cotidiano escolar? }\end{array}$ & 4,66 &, 59 & 4,81 &, 56 & $0,000 * *$ \\
\hline 12 & $\begin{array}{l}\text { O recurso computacional estimula o desenvolvimento } \\
\text { cognitivo no aprendizado escolar? }\end{array}$ & 4,16 & ,95 & 4,43 &, 87 & $0,000 * *$ \\
\hline 13 & O recurso computacional adotado na disciplina & 4,78 &, 54 & 4,83 &, 50 & 0,098 \\
\hline
\end{tabular}


ministrada é adequado ao público-alvo da instituição de ensino?

14 pedagógica da instituição de ensino (dinamismo da aprendizagem) em relação ao seu público-alvo?

$\mathrm{O}$ recurso computacional estimula o julgamento quantitativo e/ou qualitativo do conteúdo abordado em sala de aula e/ou no laboratório de informática?

O recurso computacional é de fácil compreensão e uso?

O recurso computacional permite interação no processo de ensino-aprendizagem?

Os comandos do recurso computacional são compreendidos e claros ao utilizá-los?

As aulas são mais atrativas com o uso do recurso computacional?

O recurso computacional mantém interação constante com o conteúdo da disciplina? $\begin{array}{lllll}4,63 & , 67 & 4,74 & , 57 & 0,059\end{array}$

$3,26 \quad 1,67 \quad 3,98 \quad 1,24 \quad \mathbf{0 , 0 0 0} * *$

$\begin{array}{lllll}4,88 & , 32 & 4,93 & , 39 & 0,091\end{array}$

$\begin{array}{lllll}4,60 & , 55 & 4,75 & , 79 & \mathbf{0 , 0 0 1} * *\end{array}$

$\begin{array}{lllll}4,86 & , 45 & 4,78 & , 63 & 0,154\end{array}$

$\begin{array}{lllll}4,61 & , 59 & 4,70 & , 73 & 0,062\end{array}$

$\begin{array}{lllll}4,06 & 1,09 & 4,22 & , 93 & 0,081\end{array}$

Fonte: Dados da pesquisa.

Em âmbito geral, segundo a Tabela 1, constatou-se que a grande maioria das perguntas relacionadas ao processo de ensino-aprendizagem, tanto no Facebook quanto no WhatsApp, tendem a uma avaliação de alta concordância, pois os escores são iguais a 4,00 ou superiores. A alta concordância é avaliada na análise estatística fatorial na escala de Likert, pois quando a escala mais se aproxima do valor de cinco pontos, há concordância em relação ao item de um questionário.

Com exceção da questão 15 ( $O$ recurso computacional estimula o julgamento quantitativo elou qualitativo do conteúdo abordado em sala de aula elou no laboratório de informática?), em que os discentes, no geral, discordaram desse item. A discordância do item anterior deve-se a escala de Likert se aproximar do valor de um ponto.

Peres e Kurcgant (2004, p. 14) afirmam: "as principais críticas do computador na aprendizagem centram-se na pedagogia utilizada para a qual o aluno é o agente passivo, e o processo de ensino-aprendizagem baseia-se na absorção e assimilação de informações". Por isso, os recursos computacionais aplicados ao ensino possibilitam maior flexibilidade, criatividade e dinamicidade no processo de ensino-aprendizagem, estimulando o aluno a participar de maneira ativa na construção do seu conhecimento.

Entre os discentes, em uma análise comparativa aos recursos Facebook e WhatsApp, verificou-se a existência de diferenças significativas quanto às perguntas 1, 2, 9, 10, 11, 12, $15 \mathrm{e}$ 17, pois o teste apresentou um valor- $p$ de $0,000^{* *}$, o recurso WhatsApp foi o mais expressivo (TABELA 1), ou seja, os respondentes tende a concordar mais com o uso do WhatsApp do que 


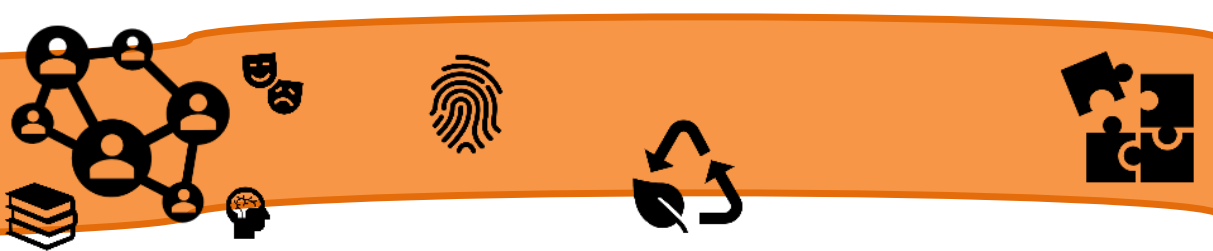

o Facebook. Para as perguntas 3, 7 e 8, o recurso computacional Facebook apresentou maior concordância do que o WhatsApp.

\section{CONSIDERAÇÕES FINAIS}

A pesquisa partiu-se do princípio que, atualmente, é relevante: o uso de ferramentas tecnológicas como apoio pedagógico ao ensino. Isso porque a educação requer aulas mais dinâmicas e motivadoras, pois os discentes são os protagonistas na construção dos seus conhecimentos e o docente é o facilitador e o mediador na transmissão dos conteúdos, com o apoio tecnológico, em sala de aula e/ou no laboratório de informática.

O resultado da aplicação dos questionários demonstra que os discentes percebem que há uma relação que favorece o uso dos recursos computacionais e a aprendizagem. Pelo resultado da análise quantitativa, as ferramentas tecnológicas utilizadas na pesquisa, como Facebook e WhatsApp, tiveram aceitação como suporte pedagógico na transmissão dos conteúdos programáticos pelo docente.

$\mathrm{Na}$ análise quantitativa da população discente percebe-se com os resultados que ao comparar as ferramentas tecnológicas, por meio das diferenças significativas realizadas pelo teste Wilcoxon, o p-valor indica um nível de significância em relação ao nível de confiança maior no WhatsApp do que no Facebook. Nesse caso, os discentes tendem a utilizar o WhatsApp com mais constância como ferramenta pedagógica no processo de ensino-aprendizagem, se comparado ao Facebook.

No ambiente escolar percebe-se que, com a utilização dos recursos computacionais, as aulas tornam-se mais prazerosas e mais significativas, porque as tecnologias usadas propiciaram interações constantes com conteúdos ministrados de forma lúdica e com questões objetivas. As questões em formato de quizzes foram resolvidas pelos alunos através dos recursos computacionais Facebook e WhatsApp propostos na pesquisa. Com todas as opções de recursos disponíveis, há facilidade de compartilhamento de materiais, downloads de arquivos e busca/pesquisa de determinado conteúdo proposto em sala de aula.

Espera-se, com os resultados deste estudo, que outras disciplinas possam utilizar recursos computacionais nas aulas, pois se percebe que, com o uso de tecnologias em sala de aula, houve ampliação do conhecimento dos discentes e que as aulas tornam-se mais atrativas pela interação constante que os recursos computacionais proporcionam com o conteúdo programático da disciplina.

A ampliação do conhecimento dos estudantes foi analisada através das atividades práticas desenvolvidas em sala de aula com o uso das tecnologias propostas na pesquisa, pois em atividades de múltiplas escolhas feitas pelos alunos por meio dos recursos computacionais, 


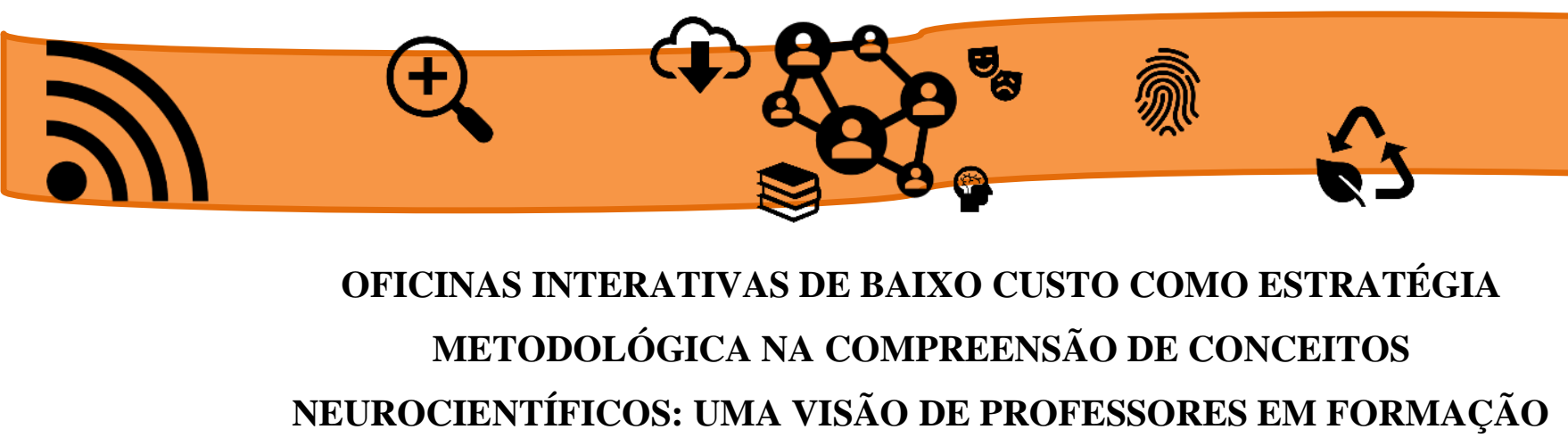

\author{
SANTOS, Ana Paula Araújo Silva dos ${ }^{54}$ \\ VENTURIERI, Bianca ${ }^{55}$ \\ LOPES, Eldeline Nascimento ${ }^{56}$ \\ CARVALHO, Midiã Ester Santos de ${ }^{57}$ \\ OLIVEIRA JUNIOR, Victor Hugo de ${ }^{58}$
}

\title{
RESUMO:
}

As metodologias práticas, como as oficinas interativas, são capazes de sedimentar, isto é, conceber de maneira prática o conhecimento teórico de conceitos científicos e complexos, como o conhecimento das Neurociências. Dentro deste contexto, o presente trabalho tem como objetivo descrever as perspectivas e vivências dos participantes da Oficina Interativa, com duração de três (3) dias, que ocorreu na XXIV Semana Acadêmica da Universidade do Estado do Pará, Campus I, em Belém/PA. Os três dias da Oficina exploraram aspectos teóricos, desde a evolução do conhecimento científico e as práticas de ensino de ciências e biologia até a contemporaneidade, como também aspectos práticos, na confecção de um modelo didático sobre a temática das neurociências para aprendizagem de conceitos (neuro)científicos e potencialidades no ensino de ciências e biologia.

PALAVRAS-CHAVE: Oficinas interativas. Neurociências. Materiais alternativos.

\section{INTRODUÇÃO}

A arquitetura mental humana da atualidade foi construída durante bilhões de anos de evolução. No século XX, década de 80, a união das variadas ciências, cujo sujeito de investigação é o sistema nervoso, constituiu o que denominamos hoje de Neurociências. Esta, por sua vez, entende como o encéfalo produz a marca individual

\footnotetext{
${ }^{54}$ Graduanda em Licenciatura Plena em Ciências Naturais - Biologia pela Universidade do Estado do Pará (UEPA). E-mail: anapaulaaraujo.luz@outlook.com

${ }^{55}$ Doutora em Educação para Ciências pela Universidade Estadual Paulista (UNESP). Professora efetiva dos cursos de Ciências Naturais da UEPA. E-mail: bianca.venturieri@gmail.com

${ }^{56}$ Graduanda em Licenciatura Plena em Ciências Naturais - Biologia pela Universidade do Estado do Pará (UEPA). E-mail: lopesn67@gmail.com

${ }^{57}$ Graduanda em Licenciatura Plena em Ciências Naturais - Biologia pela Universidade do Estado do Pará (UEPA). E-mail: estersantosss@ hotmail.com

${ }^{58}$ Graduando em Licenciatura Plena em Ciências Naturais - Biologia pela Universidade do Estado do Pará (UEPA). E-mail: victor_bio27@outlook.com
} 


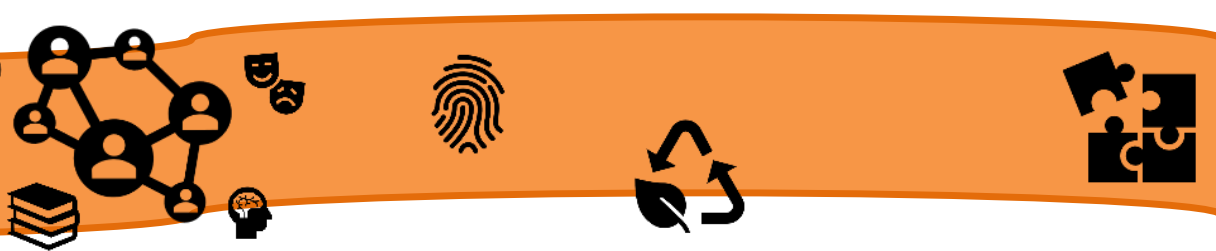

humana (KANDEL; JESSEL; SCHWARTZ, 1997), possibilitando assim a existência de uma ciência multidisciplinar que atravessa paradigmas, contribui diretamente na conduta da aprendizagem e constitui uma peça chave para o estímulo de um desenvolvimento cognitivo saudável.

O cérebro é a unidade que dá significado ao processo de aprendizagem, auxiliando a compreensão do processo de ensino e aprendizagem dos educandos a nível molecular, biológico e comportamental. Autores como Blakemore e Frith (2000) testificam, contudo, o avanço significativo das pesquisas relacionadas ao cérebro, mas que não se encontra a aplicação na teoria e na prática da educação, declarando que "por muito tempo o cérebro não tem sido mencionado nas discussões sobre educação e frequentemente não é fácil encontrar informação sobre a investigação neurocientífica" (BLAKEMORE; FRITH, 2000).

Para a maioria dos neurocientistas, as neurociências se configuram como um fator fundamental à formação docente, uma vez que devido a sua natureza multidisciplinar, conforme já frisado anteriormente, protege e estimula o professor na busca de estratégias metodológicas ao longo do processo de aprendizagem na Educação Básica. O cérebro que aprende é estimulado anatômica e fisiologicamente e, assim como há várias maneiras de pensar e aprender, também existem várias formas de ensinar. Dentro deste contexto, as oficinas interativas dispõem de uma abordagem multidisciplinar que permitem conceber de maneira prática o conhecimento neurocientífico.

Salas (2007) examina que metodologias práticas podem auxiliar os alunos na construção de memórias semânticas, episódicas, procedimentais, automáticas e emocionais. O mesmo autor descreve, ainda, a importância dos químicos de nosso cérebro, que incluem neurotransmissores, hormônios e peptídeos. A dopamina, serotonina, acetilcolina e norepinefrina, por exemplo, são neurotransmissores que estão ligados à sensação de bem-estar, humor, alegria e, consequentemente, estão associados à atenção. Quanto maior o nível de norepinefrina e serotonina, mais alto é o poder de atenção e liberdade sobre o conteúdo apreendido. O contrário também é verdadeiro (SALAS, 2007).

Para Stacciarini e Esperidão (1999), o professor deve ser capaz de criar condições que facilitem a aprendizagem do aluno e que estimulem suas curiosidades, 


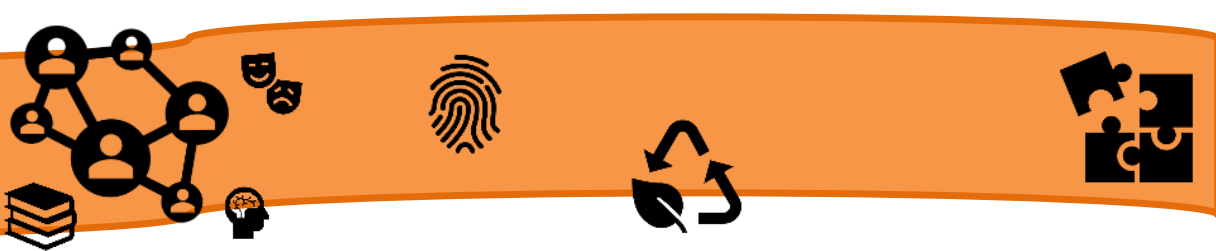

assim como motivá-los na escolha de seus próprios interesses, para a construção de um indivíduo responsável e crítico, desde que seja de forma orientada. Dentro deste contexto, Freire afirma que o educador é um profissional da aprendizagem, um profissional do sentido, um organizador da aquisição do conhecimento e, dessa forma, necessita de métodos inovadores que concentrem na aprendizagem e formação do aluno.

A Base Nacional Comum Curricular - BNCC (BRASIL, 2018), neste contexto, sinaliza as atividades práticas como um elemento importante para a compreensão ativa e prática dos conceitos (neuro)científicos, uma vez que o aluno pôde estabelecer uma relação mais significativa com o assunto ou objeto de estudo. Segundo Rosalen, Rumenos e Massabni (2014, p. 02):

as atividades práticas são importantes quando ensinadas de forma a trabalhar a busca e resolução de problemas, pois assim os alunos passam de meros espectadores à protagonistas de seu ensino, podendo experimentar e deduzir resultados, criando maior capacidade de argumentação e indução, e finalmente formando verdadeiros cientistas.

A ausência de materiais e recursos se mostram como um empecilho, contudo, para a realização de atividades práticas que facilitam a compreensão de conceitos científicos. Por isso, a utilização de materiais alternativos de baixo custo possibilitam a prática do ensino e carregam um grande potencial didático e pedagógico, uma vez que são oriundas da relação entre teoria e prática. Neste contexto, autores como Valle e Arriada (2012), defendem que as oficinas pedagógicas proporcionam a construção do conhecimento por meio da relação ação-reflexão-ação, fazendo o aluno vivenciar experiências mais concretas e significativas baseadas no sentir, pensar e agir.

Na concepção de Luria (1903-1978) o cérebro é um sistema biológico que está em constante interação com o meio. Ao longo da a evolução da espécie, da história social, e do desenvolvimento de cada indivíduo, o cérebro pode se revitalizar (neuroplasticidade), gerando assim novas possibilidades para mudar e trabalhar o ambiente e processo de ensino e aprendizagem em ciências e biologia. Em corroboração a este ponto de vista, o aprendizado é uma arma poderosa na luta pela sobrevivência e é uma característica inata do cérebro.

A dinamicidade que o cérebro carrega, como citado no parágrafo anterior, valida a ação dos educadores na relação entre teoria e prática, uma vez que os alunos podem: 
1) interagir de forma direta com os materiais; 2) formular hipóteses e 3) atuar de forma autônoma. Em corroboração a esta afirmativa, Hodson (1988) reitera que a principal função das atividades experimentais é provocar a confiança e a autoestima, a fim de prever o entendimento teórico desenvolvido pelo aluno, controlar e manipular eventos, culminando na solução de problemas.

Neste sentido, conhecer o funcionamento e as potencialidades do sistema nervoso contribuem positivamente no ensino e aprendizagem de ciências e biologia. Escribano (2007) frisa que os professores precisam estar capacitados para compreender e entender as particularidades cognitivas dos alunos de acordo com os princípios da neurociência, uma vez que o conhecimento fisiológico e patológico ajuda a melhorar as práticas educativas e diminui significativamente as dificuldades na aprendizagem. (ESCRIBANO, 2007)

Em virtude de a falta da concepção prática do conhecimento científico, muitas vezes trazer dificuldade para como o ensino de ciências é dirigido dentro das salas de aula, faz-se necessário trazer a conexão entre as neurociências e educação, de maneira desmistificada, prática e acessível. Assim, para preencher esta lacuna, o presente estudo retratará de uma Oficina Interativa, com duração de 3 (três) dias - 05, 06, 07/11 - que ocorreu durante XXIV Semana Acadêmica da Universidade do Estado do Pará, Campus I, em Belém/PA.

\section{METODOLOGIA}

A metodologia do presente estudo trata-se de uma abordagem qualitativa, a partir da execução de uma Oficina Acadêmica Interativa durante a XXIV Semana Acadêmica da Universidade do Estado do Pará, Campus I, na cidade de Belém/PA (ver figura 1 e 2), com professores em formação das licenciaturas em Pedagogia e Ciências Biológicas. Para corresponder a cada fase do estudo, a Oficina foi metodologicamente dividida em três dias de duração $(05,06,07 / 11)$. 
Figura 1 e 2: UEPA, Campus I, CCSE e Mapa do Campus.
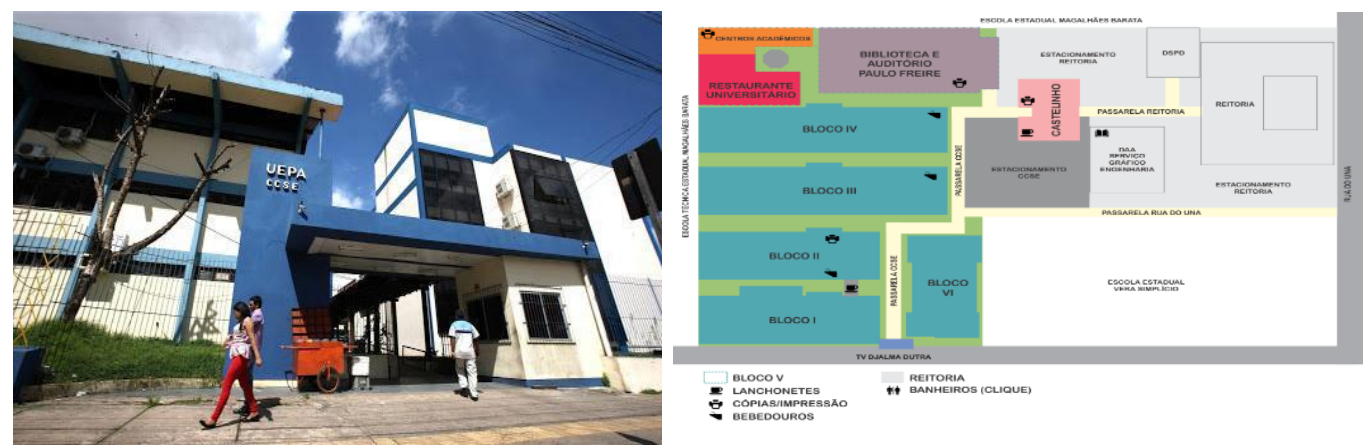

No primeiro dia, tratou-se da abordagem teórica do conhecimento das Neurociências. Para isso, foi utilizada uma linha do tempo que tratava da evolução do conhecimento científico e o ensino de ciências e biologia, os avanços e as possíveis inviabilidades no processo de ensino e aprendizagem, com enfoque nos conteúdos de sistema nervoso, que culminavam na discussão das Neurociências. Neste sentido, foram expostos alguns materiais alternativos de baixo custo para elucidar e preparar os alunos para a confecção do material didático no dia seguinte.

Figura 3 e 4: Exposição teórica no primeiro dia de Oficina.

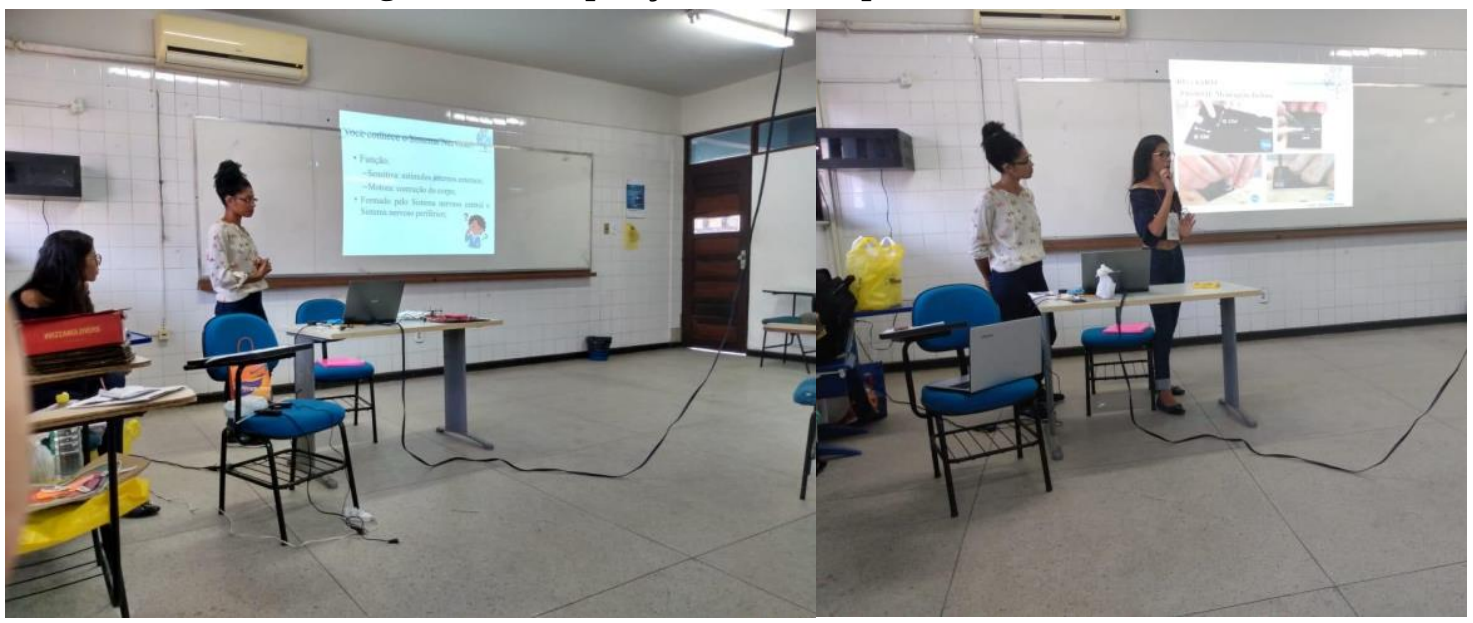

No segundo dia, por sua vez, os alunos tiveram contato com a concepção prática do estudo. Tendo como ponto de partida de que o processo de aprendizagem do cérebro está na neurociência celular, destacou-se a importância dos neurônios, que têm como função básica receber, processar e enviar informações. A partir do uso de materiais alternativos de baixo custo, como papéis-cartão coloridos e papelão, os participantes 
puderam confeccionar o modelo didático de um neurônio, a célula básica do sistema nervoso (ver figura 3 e 4 ).

Figura 4 e 5: Confecção do modelo didático do neurônio.
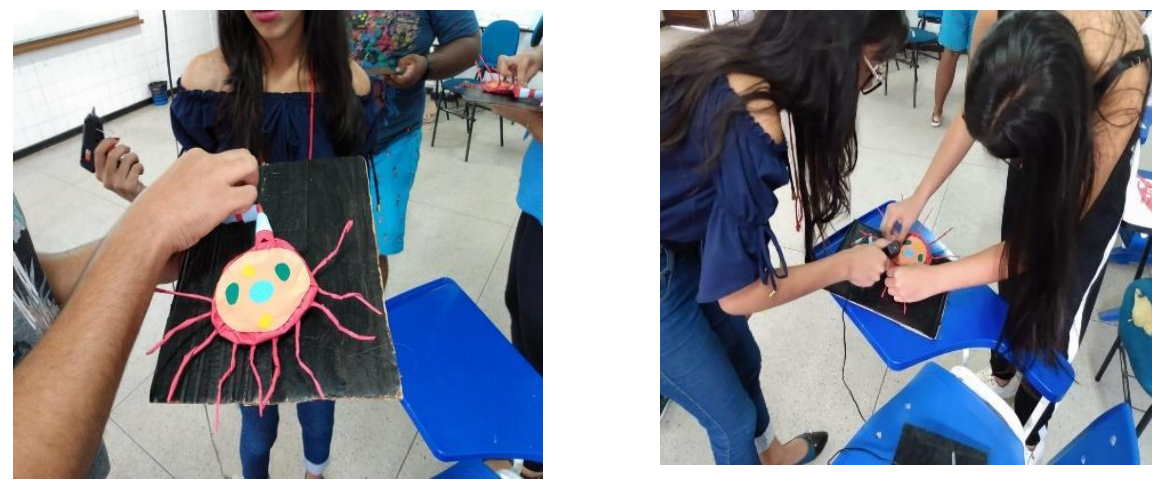

No terceiro e último dia da Oficina, por sua vez, foi realizada uma discussão sobre a importância da oficina interativa para a concepção prática do funcionamento do sistema nervoso, assim como o conhecimento das Neurociências. Em seguida, com base na discussão e nos conhecimentos adquiridos, os participantes preencheram um questionário com questões que abordavam sobre o conceito de sistema nervoso, eficácia dos materiais alternativas e o conhecimento das neurociências ao longo da sua formação acadêmica (ver tabela 1).

\begin{tabular}{|c|c|}
\hline Questão & Texto da Questão \\
\hline 1 & O que você pôde entender sobre o conteúdo do Sistema Nervoso com Base na Oficina \\
Interativa?
\end{tabular}

Tabela 1: Questões do questionário aplicado no terceiro dia da Oficina Interativa.

\section{RESULTADOS E DISCUSSÕES}

Os resultados foram analisados pela análise qualitativa das respostas dos participantes no questionário de aplicação. As respostas apontaram que os alunos conceberam de forma prática a extensão do sistema nervoso, assim como a importância 


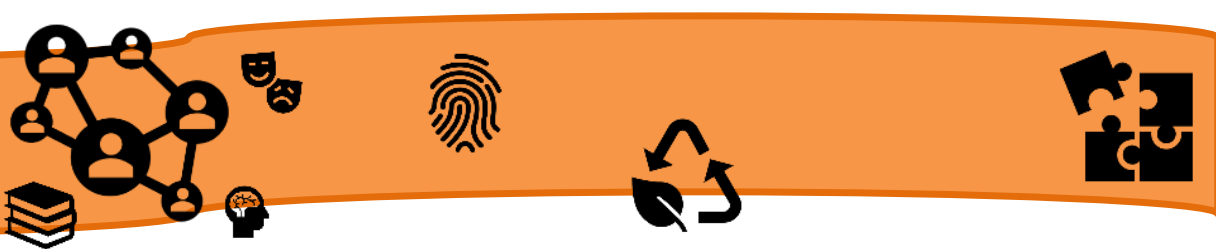

e funcionalidade da célula básica do sistema nervoso, o neurônio. Além disso, constataram que o modelo didático seria eficaz como uma ferramenta auxiliar para uma possível aula de Sistema Nervoso.

"Às vezes, é muito difícil pensar como seria uma célula. A única concepção que nós temos é no que a gente ver em livros didáticos e outras coisas. Quando a gente coloca a mão na massa e tem esse contato ativo com a aprendizagem, é bem diferente. Usar matérias de baixo custo para isso, como papelão e cola quente, mostra ainda ser mais acessível aplicar em uma sala de aula que, na maioria das vezes, não dispõe de recursos pedagógico que facilitem o ensino de conteúdos complexos, como o Sistema Nervoso. A criatividade do professor também é um fator importante na confecção desses recursos." (Participante da Oficina I, 2019).

Em concordância com a fala anterior, autores como Alencar e Fleith (2003) ressaltam que não há como negar a importância da criatividade no contexto escolar e a necessidade de promovê-la na formação dos alunos, uma vez que a contemporaneidade requer professores criativos que formem alunos criativos e reflexivos.

Sobre a questão do termo Neurociências ao longo da graduação, os participantes revelaram nunca ter ouvido e nem ouvido da aplicabilidade da área no ensino de Ciências e Biologia, ainda que grande parte fosse dos cursos de licenciaturas em Ciências Biológicas. Porém, depois da Oficina, eles puderam elucidar e visualizar a multidisciplinaridade do tema:

"Entendi, depois da Oficina, que as Neurociências vão além de estudar os neurônios ou o cérebro, mas a ação destes na conduta humana. Por isso, eles atravessam as mais diversas áreas, como a filosofia, antropologia e sociologia e contribuem o avanço da sociedade como um todo." (Participante da Oficina II, 2019)

"Para mim, até antes da Oficina, era algo muito abstrato. Acho que isso mostra um déficit na própria formação deles e, por essa razão, eles não se sentem seguros em abordar. Então, se é algo abstrato pra eles, consequentemente acaba sendo algo abstrato pra gente também, mas com a Oficina Interativa pude enxergar novas oportunidades de eu explorar essa temática com os meus alunos da educação básica." (Participante da Oficina Interativa III, 2019).

A falta anterior corrobora com o descrito por Viera e Volquind (2002, p. 11), pois se caracteriza como sendo "um sistema de ensino-aprendizagem que abre novas possibilidades quanto à troca de relações, funções, papéis entre educadores e 
educandos". Portanto, de forma participativa e questionadora como a natureza da oficina carrega, os participantes puderam ter uma aprendizagem mais completa e multidisciplinar do que são as Neurociências, a partir do ponto de partida da sua aplicabilidade às outras ciências e áreas de ensino.

\footnotetext{
"As Neurociências vão além de estudar os neurônios e as suas funções para a (re)ação do ser humano. Contribui, diretamente, no avanço da ciência, nas pesquisas e descobertas do estudo do cérebro para beneficio da sociedade e do ensino." (Participante da Oficina IV, 2019.)
}

Uma das maiores dificuldades ao longo do processo educacional de um professor é atrair a atenção e a participação ativa nas aulas. Neste contexto, as estratégias metodológicas são capazes de promover o estímulo e a motivação dos alunos, principalmente dos alunos docentes em formação, que por sua vez atuarão como educadores da Educação Básica.

Hofstein e Lunetta (1982, p. 203) destacam que as aulas interativas no ensino das ciências têm as funções de despertar e manter o interesse dos alunos, uma vez que instigam e desenvolvem habilidades e capacidade de resolver problemas e compreender conceitos básicos. Além disso, permitir que os alunos manipulem os materiais, produzam algo ou mesmo por si próprio experenciam.

\section{CONSIDERAÇÕES FINAIS}

O conteúdo teórico do sistema nervoso é considerado complexo e abstrato. Com a construção do modelo didático com materiais de baixo custo, contudo, pôde maximizar a compreensão e permitir a concepção prática do conteúdo e a aplicabilidade com as Neurociências e a Educação. Os recursos didáticos para o ensino de ciências e biologia são capazes de construir um conhecimento mais aprofundado, tornando a aula significativa e dinâmica, além de ter possibilitado a interação, o processo dialógico e o pensar coletivamente entre todos participantes. Portanto, a estratégia metodológica de ensino mostrou-se de grande importância e eficácia para o ensino e aprendizagem de conceitos (neuro)científicos em ciências e biologia.

\section{REFERÊNCIAS}




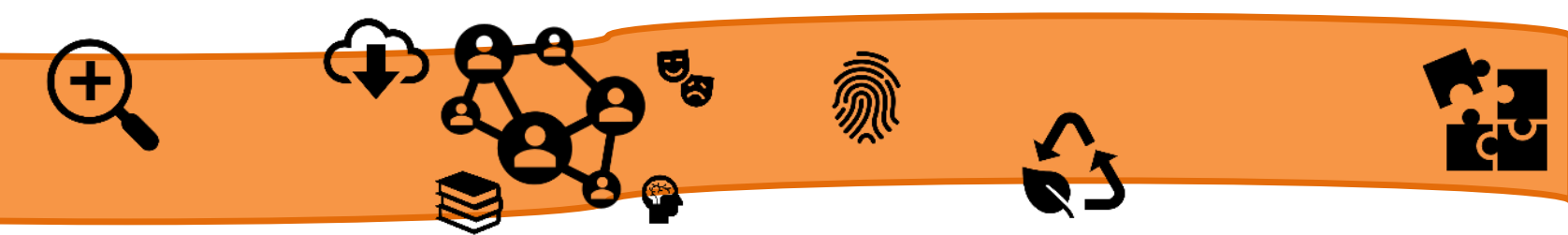

ALENCAR, E. M. L. S.; FLEITH, D. S. (2003). Criatividade: múltiplas perspectivas. Brasília: Universidade de Brasília.

BRASIL. Base Nacional Comum Curricular: Ensino Médio. Brasília: MEC/Secretaria de Educação Básica, 2018.

BLAKEMORE, S.; FRITH, U. The implications of recent developments in Neuroscience for research on teaching and learning. London: Institute of cognitive Neuroscience, 2000.

DO VALLE, H.S; ARRIADA, E. "Educar para transformar": a prática das oficinas. Revista Didática Sistêmica, v. 14, n. 1, p. 3-14, 2012.

ESCRIBANO, C. L. Contribuciones de la neurociencia al diagnóstico y tratamiento educativo de la dislexia del desarrollo. Revista de Neurología, Barcelona, v. 44, n. 3, p. 173-180, 2007.

HODSON, D. Experiments in science and science teaching. Educational Philosophy and Theory, v. 20, n. 2, p. 53-66, 1988;

HOFSTEIN, A.; LUNETTA,V. N. The role of the laboratory in science teaching: neglected aspects of research, Review of Educational Research, n. 52, p. 201-217, 1982.

KANDEL, E.; SCHWARTZ. J.; JESSEL, T. Neurociencia y conducta. Madrid: Prentice Hall, 1997.

ROSALEN, Stefania; RUMENOS, Nijima Novello; MASSABNI, Vânia Galindo. Atividades práticas e recursos de informática como apoio ao ensino de biologia. Anais. São Carlos: USP, 2014

SALAS, R.. Educación y Neurociencia. Cómo desarrollar al máximo las potencialidades cerebrales de nuestros educandos. Asunción, PY: Universidad Americana, 2007.

STACCIARINI, J.M.R.; ESPERIDIÃO, E. Repensando estratégias de ensino no processo de aprendizagem. Ver. Lat-Americ. Enfermagem, Ribeirão Preto, v. 7, n. 5, p.59-66, dez. 1999.

VIEIRA, Elaine; VOLQUIND, Lea. Oficinas de Ensino: o quê, por quê? Como? 4. ed. Porto Alegre: Edipucrs, 2002. (Série educação, 3). 




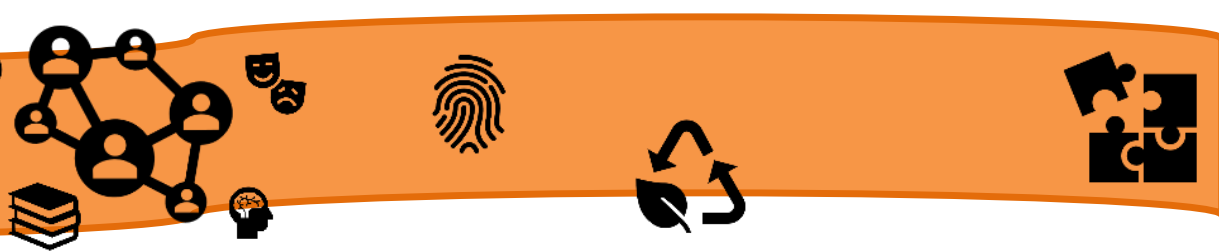

O presente artigo aborda a experiência vivenciada pelos alunos do $1^{\circ}$ período do curso de Enfermagem da Faculdade Evolução Alto Oeste Potiguar (FACEP), como participantes na modalidade ouvinte da VI Conferência de Saúde do município de Encanto, no estado do Rio Grande do Norte, com o tema "Democracia e saúde", com participação da sociedade e autoridades públicas do referido município.

O evento foi realizado em maio de 2019, na Câmara Municipal da referida cidade e contou com a presença de profissionais de saúde, acadêmicos, autoridades como o prefeito do município, a secretária de saúde, um conferencista, além de populares e outros setores da sociedade.

A Conferência deu início às 07:30 da manhã com a Abertura e formação da mesa de autoridades, seguido pelo Hino Nacional, leitura e aprovação do regulamento da Conferência pela plenária, leitura do relatório de saúde da cidade, o qual, evidenciou dados sobre os estabelecimentos de saúde, doenças, exames realizados, dentre outros serviços realizados pelo SUS. Em seguida, duas palestras com as seguintes temáticas: "Saúde como direito e consolidação" e "Financiamento do SUS", ambas ministradas por enfermeiros da respectiva cidade.

Por fim, houve a divisão de grupos para levantar teses para a melhoria dos serviços de saúde local, que foram expostas posteriormente em plenária, encerrando todas as apresentações e o evento às 13:00 horas.

\section{RESULTADOS E DISCUSSÕES}

A CNS constitui um importante evento de controle social, que conta com a participação não só da população, mas de trabalhadores dessa área, prestadores dos serviços, sejam públicos ou privados, e de autoridades de saúde. Assim, é um espaço para debater e deliberar sobre os problemas de saúde pública e desafios para a melhoria das condições de vida no Brasil, possibilitando um SUS mais democrático (MIRANDA, 2016).

Nos dias atuais, as conferências de saúde ocorrem no mínimo a cada (4) anos e são organizadas em etapas, que permitam a participação das três esferas: Municipal, Estadual e Federal, seguindo a sequência respectivamente. Vale ressaltar a importância da participação de vários campos da sociedade, uma vez que os principais intuitos das CNS são analisar, tratar e buscar soluções para os impasses na saúde, juntos, 


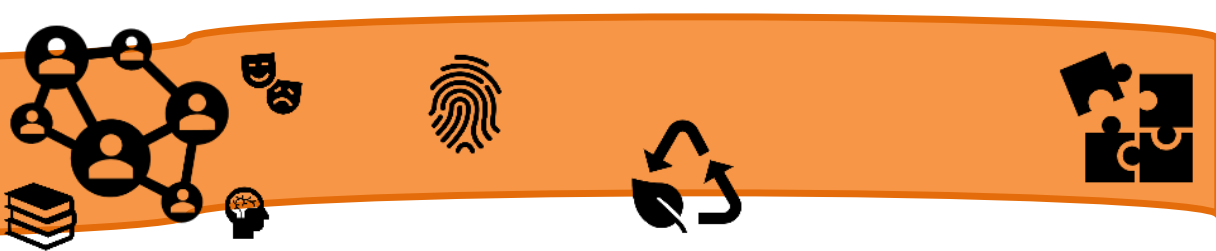

ocasionando que o processo seja realizado de uma forma democrática e que as necessidades de todos sejam atendidas (RICARDI, 2017).

A $6^{\mathrm{a}} \mathrm{CMS}$ da cidade do Encanto abordou no evento, questões sobre direito à saúde dos cidadãos, temática bastante relevante e que oferece informações essenciais para os indivíduos em meio à sociedade. Nesta perspectiva, foi possível discutir a saúde como um direito que deve ser garantido a todos, como consta na Constituição e na Declaração dos Direitos Humanos de 1948 (LOVATO, 2015).

Entender o papel do SUS na garantia desse direito, portanto, é de suma importância, pois ele foi criado para diminuir as dificuldades, assegurar, promover e recuperar a saúde dos indivíduos com universalidade, integralidade e equidade. Neste sentido, as conferências como um todo contribuem para que as pessoas ali presentes entendam seus direitos na busca por uma saúde digna, como cidadãos, e a importância de reivindicar ações e serviços condizentes com sua realidade (GADELHA, 2015).

Num segundo momento, foram tratados assuntos relacionados às questões orçamentárias e financeiras do SUS. Assim sendo, é importante esclarecer que os custeios desse sistema assim como a organização e a execução das suas ações e serviços são descentralizados, ou seja, cada ente federativo, município, estado e união, tem sua responsabilidade (RODRIGUES, 2014).

Atualmente o SUS vem enfrentando desafios no que diz respeito ao financiamento, levando em consideração a lei complementar 141/2012, que estabelece a responsabilidade de cada esfera no custeio dos serviços ofertados pelo SUS, munícipios $15 \%$, estados $12 \%$ e União pela variação do PIB. Na prática, isso não ocorreu, pois no ano de 2015 os gastos da união com saúde corresponderam apenas 3,9\% do total, fazendo com que os munícipios, aumentassem sua participação, o que gerou grande impacto principalmente naqueles mais pobres que chegam a gastar cerca de $23 \%$ de seus recursos na saúde (MARQUES, 2016).

\section{CONSIDERAÇÕES FINAIS}

A experiência de participar de uma conferência de saúde, permite, portanto, a compreensão de que o controle social por meio dela, remete a um fator democrático, desenvolvido pela luta do povo e pelo direito universal à saúde, fazendo jus ao lema 
RICARDI, Luciani Martins; SHIMIZU, Helena Eri; SANTOS, Leonor Maria Pacheco. As Conferências Nacionais de Saúde e o processo de planejamento do Ministério da Saúde. Saúde em Debate, V. 41, N. ESPECIAL 3, P. 155-170, 2017.

RODRIGUES, P H A. Desafios políticos para a consolidação do Sistema Único de Saúde: uma abordagem histórica. História, Ciências, Saúde. 2014, v. 21, n. 1, pp. 37 59. Acesso em 03 de Set de 2019. Disponível em:

http://www.scielo.br/pdf/hcsm/v21n1/0104-5970-hcsm-21-1-00037.pdf

ROLIM, Leonardo Barbosa ; CRUZ, Rachel de Sá Barreto Luna Callou; SAMPAIO, Karla Jimena Araújo de Jesus. Participação popular e o controle social como diretriz do SUS: uma revisão narrativa. Saúde em Debate, v. 37, n. 96, p. 139-147, jan./mar. 2013. 



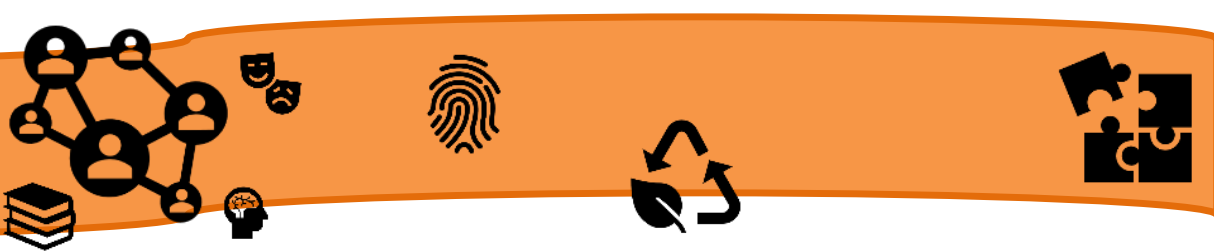

uma teoria e prática educativa que possibilite vivências de autonomia e uma transformação social.

A teoria de Piaget sobre o desenvolvimento moral trata da relação entre ação e consciência e de como o sujeito chega a respeitar as regras morais. Ela pode colaborar para refletirmos sobre a opressão, visando uma sociedade em que o respeito e a justiça prevaleçam. Possibilita-nos discutir problemáticas específicas da nossa sociedade e da educação.

Freire e Piaget tratam a questão da construção do conhecimento de forma semelhante, considerando a ação, prática e interiorizada, como essencial para que o sujeito alcance uma forma de pensar crítica e coerente. As epistemologias que embasam as teorias de Freire e Piaget chegam a assumir quase uma identidade, já destacada por Becker (2011) em uma pesquisa sobre a aprendizagem.

Piaget possui uma teoria explícita e sistematizada sobre o desenvolvimento moral, já Freire apresenta, em suas obras, aspectos sobre moral, que revelam um modo de pensar o seu desenvolvimento. Notamos eixos em que suas ideias sobre moral dialogam e assumem aproximações. Discutiremos um destes eixos, o respeito.

\section{OBJETIVO}

Nosso objetivo é verificar quais são as aproximações possíveis entre as teorias de Jean Piaget e Paulo Freire sobre o respeito no desenvolvimento moral. Buscamos investigar e aprofundar a compreensão dos aspectos morais presentes na teoria de Piaget e de Freire e demonstrar as aproximações entre elas no que tange à moral, em especial, sobre o respeito mútuo.

\section{METODOLOGIA}

Esta discussão insere-se em uma pesquisa maior de uma tese de Doutorado que buscou verificar quais são as são as aproximações entre as teorias de Jean Piaget e Paulo Freire, quanto a aspectos do desenvolvimento moral, e analisar quais as implicações dessas aproximações para a teoria e a prática educativa.

Utilizamos a pesquisa bibliográfica. Consultamos obras centrais dos autores, que abordam questões sobre moral, e também obras periféricas. Nelas conhecemos o olhar 
político e epistemológico dos autores, aspectos que nem sempre são considerados e que são importantes para entender o desenvolvimento moral.

\section{A MORAL EM PIAGET}

Piaget estruturou uma teoria sobre o desenvolvimento moral, compilada, especialmente, em O juízo moral na criança ([1932], 1994). De acordo com Freitas (2003, p. 60), “[...] pode ser entendido como um estudo psicogenético das relações entre o respeito e a obrigação moral".

Buscou compreender como a consciência humana chega a respeitar as regras morais, e verificou que o respeito pelas outras pessoas é essencial na constituição da obrigação moral. A regra social só é considerada válida e deve ser seguida se há entre os indivíduos um sentimento de respeito que permite que a regra seja boa para todos. Há, assim, uma essência totalmente humana da moral.

Uma regra é um fato social, que supõe uma relação entre pelo menos dois indivíduos. E esse fato social repousa sobre um sentimento que une esses indivíduos uns aos outros, que é o sentimento de respeito: há regra quando a vontade de um indivíduo é respeitada pelos outros ou quando a vontade comum é respeitada por todos. (PIAGET, 1998, p. $63)$.

O desenvolvimento moral é fruto de construções e reconstruções progressivas, que se dão na interação sujeito-meio. Do nascimento aos primeiros anos de vida, vivemos uma ausência de regras, mas, ainda pequenos, somos inseridos em um contexto regrado e iniciamos a construção de tendências morais.

Piaget ressaltou que ação e consciência moral estão intimamente ligadas, evoluem no sentido da reciprocidade. Deixam gradativamente de ser egocêntricas e guiadas pelo que é externo e vão sendo permeadas pela coordenação entre o que é bom para mim e o que é bom para o outro. A consciência chega à autonomia moral quando é capaz de guiar-se por si mesma, com princípios próprios, mas considerando o todo; a autonomia moral é fruto da lei de reciprocidade que a consciência encontra nas relações de cooperação. Para o autor, "é a partir do momento em que a regra de cooperação sucede à regra de coação que ela se torna uma lei moral efetiva" (PIAGET, [1932], 1994, p. 64). 


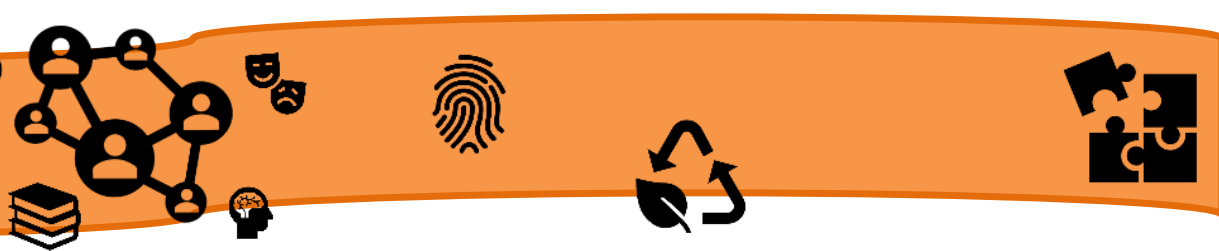

No desenvolvimento moral a ação precede a consciência. Além de todas as características da tomada de consciência cognitiva, destacadas por Piaget ([1974], 1977), a tomada de consciência moral envolve questões de afeição mútua e reciprocidade.

"Na realidade, acreditamos que, mesmo na criança, a reflexão moral teórica consiste numa tomada de consciência progressiva da atividade moral propriamente dita" (PIAGET, [1932], 1994, p. 140).

Aquilo que aparece primeiro na ação pode estar em último na consciência, pois a tomada de consciência inverte a posição das noções. E o juízo que a criança faz de seus próprios atos é bem mais tênue do que o que faz em relação aos atos do outro, pois a ação do outro aparece mais facilmente em sua materialidade do que em sua intencionalidade.

A criança pode estar vivenciando, na prática, uma determinada regra de forma mais autônoma, enquanto, na consciência, para essa mesma regra as tendências sejam mais heterônomas. Também, pode estar na prática e na consciência tratando uma regra de maneira autônoma e outra regra de modo mais heterônomo.

Dongo-Montoya (2017) destaca que, para Piaget, existem reações de altruísmo e partilha que são percebidas nos bebês. Mas, não é possível considerar que somente essas reações individuais levem à autonomia. Para que a igualdade e a reciprocidade se efetivem, é preciso a regra coletiva, que só é possível na vida em sociedade. Apesar dessas primeiras reações altruístas, a coação adulta somada ao egocentrismo infantil leva a criança ao realismo moral e à responsabilidade objetiva.

Piaget relata que há nas crianças, especialmente nas menores, o realismo moral, que consiste em considerar as regras como verdades absolutas que devem ser seguidas literalmente e sem questionamentos. Também entre os pequenos prevalece uma avaliação das situações pelos prejuízos materiais ao invés das intenções empregadas. Tais posturas são heterônomas.

Mas, as experiências cada vez mais fortes de cooperação, permeadas pelo respeito mútuo e pela reciprocidade, fazem com que a criança sinta a necessidade de tratar o outro como gostaria de ser tratada, comece a coordenar pontos de vista e avaliar as regras pela própria consciência. As ações começam a ser consideradas em função das intenções e não da materialidade, com responsabilidade subjetiva. 


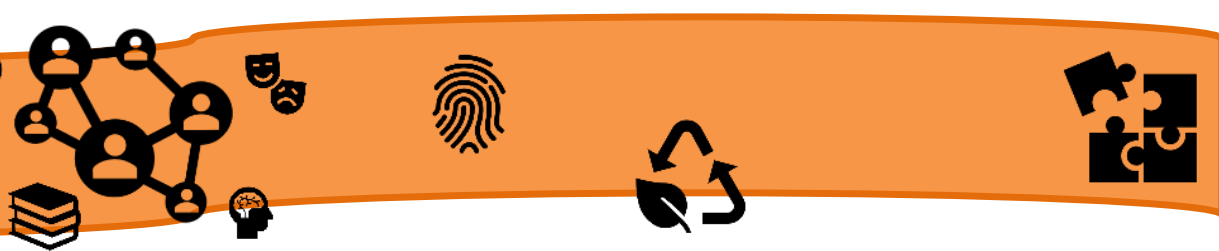

Para Piaget, as relações cooperativas costumam acontecer especialmente nas relações entre pares. $\mathrm{Na}$ cooperação os sujeitos vivenciam o respeito mútuo e a reciprocidade necessária para o desenvolvimento da autonomia. "[...] desde que haja cooperação, as noções racionais do justo e do injusto tornam-se reguladoras do costume, porque estão implicadas no próprio funcionamento da vida social entre iguais [...]" (PIAGET, [1932], 1994, p. 67).

É a partir da vivência efetiva da cooperação que o espírito toma consciência das leis de reciprocidade, as regras fazem sentido e podem ser modificadas para que sejam justas para todos. Segundo Menin (1996, p. 46),

[...] primeiro a criança pratica a construção das regras, aplica-as, muda-as no grupo, cria novas... depois é que descobre que as regras não são sagradas, imutáveis, eternas... E quando a criança acha imutáveis e sagradas as regras que vêm dos mais velhos - consciência -, sua prática é ainda imitativa e egocêntrica!

Existem duas tendências morais de natureza totalmente diferentes: a heteronomia, que não se trata de um equilíbrio estável e a autonomia, o equilíbrio ideal para onde deve caminhar o desenvolvimento moral.

\section{A MORAL EM FREIRE}

Freire não sistematizou uma teoria sobre o desenvolvimento moral, mas inseriu em sua obra aspectos morais que evidenciam uma forma de compreender tal desenvolvimento. Sua teoria é marcada pelo olhar para as especificidades humanas e pela luta pela superação da opressão. Ele se colocou a favor da transformação da situação desumanizadora e para isso destacou, além das questões de conhecimento, aquelas relacionadas à moral.

O homem e a mulher vivenciam relações com o mundo e com as pessoas. Freire evidenciou que as relações sociais podem ser tanto de opressão, em que prevalece a coação e as verdades são impostas para serem seguidas sem questionamentos, como relações dialógicas, permeadas por sentimentos e valores altruístas, prevalecendo a cooperação.

O ser humano, capaz de fazer escolhas e assumir responsabilidades, é ético.

Mulheres e homens, seres histórico-sociais, nos tornamos capazes de comparar, de valorar, de intervir, de escolher, de decidir, de romper, 


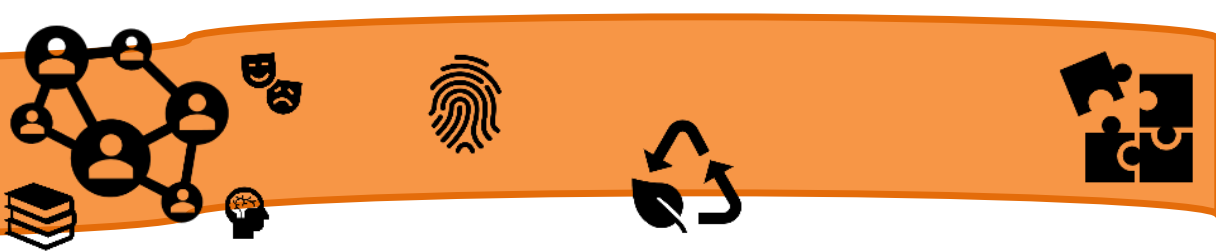

por tudo isso, nos fizemos seres éticos. Só somos porque estamos sendo. Estar sendo é a condição entre nós para ser. Não é possível pensar os seres humanos longe, sequer, da ética, quanto mais fora dela. (FREIRE, [1996], 2016, p. 34).

Ao tratar da educação, Freire se preocupa com a ética. Em Pedagogia da Autonomia ([1996], 2016), fala que a prática educativa deve considerar a ética necessária ao educador e ao educando, em favor da autonomia. Trata de uma ética verdadeira, em que ações e julgamentos possam ser aplicados a todos.

Destacando que as relações de opressão são permeadas pela violência e conduzem a uma posição passiva e silenciada, Freire se coloca a favor das relações dialógicas, em que predomina a reciprocidade e um posicionamento mais crítico. A autonomia almejada por Freire é também moral. A educação é considerada uma possibilidade para o seu desenvolvimento.

A condição própria do ser humano é a do "Ser mais", não um ser mais que hierarquiza, mas em que todos podem ser humanos, sem ferir a integridade do outro. As relações de opressão podam essa condição humana, elas diminuem, coisificam e violentam. Para Freire, “[...] a desumanização, mesmo que um fato concreto na história, não é, porém, destino dado, mas resultado de uma 'ordem' injusta que gera a violência dos opressores e esta, o ser menos." (FREIRE, [1970], 2011, p. 41).

Em Freire, as relações sociais não são únicas e podem levar a formas diferentes de respeito e de relação com as regras. As opressoras levam a um respeito que é marcado pela desigualdade de forças, uma forma de submissão. As dialógicas proporcionam um respeito de sujeitos que se consideram como iguais e se valorizam. Estas últimas que levam à autonomia, verdadeira vocação do "Ser Mais".

Freire discute a problemática da autoridade e da liberdade, com singular olhar moral. Ressalta a importância da autoridade, entendida não como autoritarismo, mas uma postura necessária à autonomia. Também trata do como a regra chega a constituirse uma necessidade. Sua posição é de que as vivências de relações dialógicas permitem que homens e mulheres sintam a necessidade de regras legítimas.

Em Freire o desenvolvimento moral também caminha da heteronomia à autonomia, passando por transições. A autonomia, para ele, é a liberdade para fazer escolhas e assumir responsabilidades, permeada pelo respeito mútuo e reciprocidade, 
critica o suficiente para levar ao engajamento pela transformação das realidades injustas e opressoras.

Freire realizou uma pesquisa específica sobre moral, preocupado com questões como as relações entre pais e filhos, ou professor e alunos, que implicam no modo de se posicionar na sociedade. Ele faz referência positiva à obra O Juizo Moral na Criança. Conclui que a relação dialógica e amorosa entre o adulto e a criança é capaz de superar a coação.

Baseando-me num excelente estudo de Piaget sobre o código moral da criança, sua representação mental do castigo, a proporção entre a provável causa do castigo e este, falei longamente citando o próprio Piaget, sobre o assunto, defendendo uma relação dialógica, amorosa, entre pais, mães, filhas, filhos, que fosse substituindo o uso dos castigos violentos. (FREIRE, [1992], 2008, p. 25).

Para Freire, a liberdade é contrária à opressão; na liberdade se vive o respeito mútuo, necessário à autonomia e à democracia.

A moral em Freire é ainda encontrada em sua concepção de que a opressão coisifica a pessoa, impedindo-a de viver livremente suas escolhas e o respeito. Essa negação do ser humano é uma violência, permeada por questões morais, sobre as quais Freire não é neutro. Salienta Andreola (1999, p. 76): "na denúncia dessa perversão ontológica, que passa a ser uma perversão ética das mais nefastas para a convivência humana hoje, Freire argumenta baseado na relação dialética entre o ser e o ter, sendo o ter absolutizado por parte da classe dominante".

A opressão não é uma incapacidade intelectual, tanto do opressor como do oprimido, de se colocar no lugar do outro, ela tem caráter especificamente moral, afetivo e social. Trata-se de uma falta de valores e sentimentos morais.

Freire tratou da tomada de consciência como essencial no processo de desenvolvimento e aprendizagem humana. A consciência parte da ação e evolui de um nível ingênuo e acrítico, passando por transições, e chegando a uma análise efetiva e crítica da realidade, a ponto de se tornar compromisso e ação (FREIRE, [1980], 2001). A conscientização, a consciência crítica e engajada na luta por uma realidade mais humana, é permeada por questões morais, pois não é possível se engajar na luta se não há respeito por si e pelos outros, ela engloba sentimentos altruístas que impulsionam a busca pela justiça e pelo bem comum. 


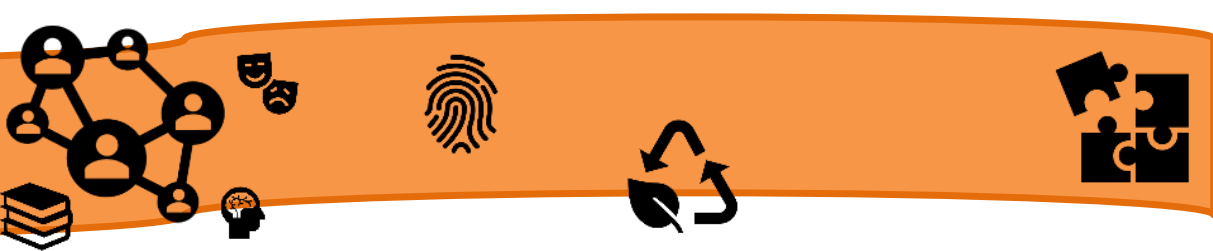

boas para todos. A autonomia é o ideal moral tanto em Piaget como em Freire. É na autonomia moral que homens e mulheres assumem uma postura altruísta, podendo agir pela transformação das relações de opressão, visando um mundo mais humano.

Piaget e Freire apontam a educação como possibilidade dessas relações de cooperação e respeito mútuo. A educação assume, então, um formato para além da formação intelectual, visa à formação mais humana, de sujeitos capazes de pensar intelectualmente e moralmente, de maneira coordenada.

\section{REFERÊNCIAS}

ANDREOLA, B. A. Interdisciplinaridade na obra de Freire: uma pedagogia da simbiogênese e da solidariedade. In: STRECK, D. R. (Org.). Paulo Freire: ética, utopia e educação. Petrópolis, RJ: Vozes, 1999. p. 67-94.

BECKER, F. O caminho da aprendizagem em Jean Piaget e Paulo Freire: da ação à operação. 2. ed. Petrópolis, RJ: Vozes, 2011. 296p.

DONGO-MONTOYA, A. Prática e teoria no desenvolvimento: questão da tomada de consciência. Psicologia Escolar e Educacional. São Paulo, SP, v. 21, n. 2, p. 235-244, 2017.

FREIRE, P. Extensão ou comunicação? Tradução de Rosisca Darcy de Oliveira. 12. ed. Rio de Janeiro: Paz e Terra, [1969], 1977. 93p.

FREIRE, P. Conscientização: teoria e prática da libertação - uma introdução ao pensamento de Paulo Freire. 3. ed. São Paulo: Centauro, [1980], 2001. 117p.

FREIRE, P. Pedagogia da esperança: um reencontro com a pedagogia do oprimido. Notas de Ana Maria Araújo Freire. 15. ed. Rio de Janeiro: Paz e Terra, [1992], 2008. $245 \mathrm{p}$.

FREIRE, P. Pedagogia do oprimido. 50. ed. Rio de Janeiro: Paz e Terra, [1970], 2011. $253 p$.

FREIRE, P. Pedagogia da autonomia: saberes necessários à prática educativa. 54. ed. Rio de Janeiro: Paz e Terra, [1996], 2016. 143p.

FREITAS, L. A moral na obra de Jean Piaget: um projeto inacabado. São Paulo: Cortez, 2003. 126p.

PIAGET, J. A tomada de consciência. Tradução de Edson Braga de Souza. São Paulo: Melhoramentos, [1974], 1977. 212p

PIAGET, J. O juízo moral na criança. Tradução de Elzon Lenardon. 4. ed. São Paulo: Summus, [1932], 1994. 302p. 
PIAGET, J. Sobre a pedagogia: textos inéditos. Org. de Silvia Parrat-Dayan. Tradução de Claudia Berliner. São Paulo: Casa do Psicólogo, 1998. 262p.

MENIN, M. S. D. Desenvolvimento moral: refletindo com pais e professores. In:

MACEDO, L. (Org.) Cinco estudos de desenvolvimento moral. São Paulo: Casa do Psicólogo, 1996. p. 37-104. 


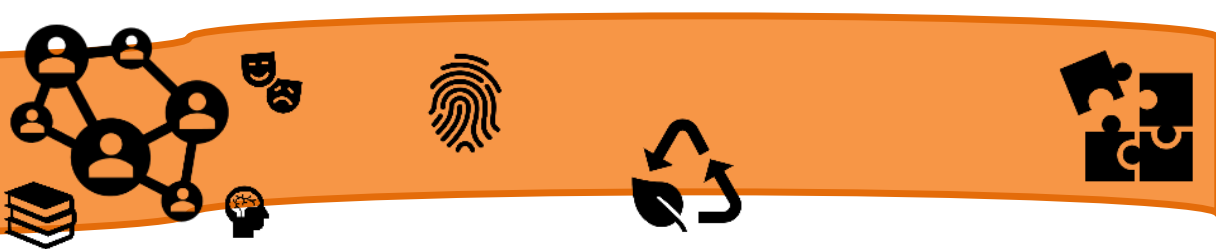

\section{RESGATANDO NOSSA HISTÓRIA}

BENVENUTTI, Guilherme Renan ${ }^{66}$

\section{RESUMO:}

Este trabalho pretende apresentar uma atividade pedagógica de pesquisa de História local, aplicada a uma turma de $9^{\circ}$ ano do ensino fundamental, ligando a atividade desenvolvida à necessidade de se trabalhar com os estudantes na área de ciências humanas, fatos que estão intimamente ligados a vida cotidiana despertando o interesse dos mesmos no estudo e na compreensão da importância de conhecer a História.

PAlaVRAS-CHAVE: História local. Produção Agrícola. Costumes. Comunidade. Escola.

\section{INTRODUÇÃO}

Em tempos de avanços tecnológicos as pessoas acabam por se distanciar de um passado que em termos de tempo não está distante, deixando de lado as raízes históricas e todo o processo de evolução no pensamento e na forma de produzir dos homens.

O mesmo distanciamento pode ser observado no cotidiano escolar dos alunos do ensino fundamental da Escola de Ensino Fundamental Prefeito Isidoro Giacomo Savaris. Durante as aulas de História é possível observar que muitos desconhecem a história por trás da criação da comunidade em que a escola está inserida, tampouco o processo histórico da criação da comunidade até os dias atuais, os ciclos da economia, as evoluções nas práticas agrícolas que são a base da economia regional.

Dificultando, desta maneira, a construção da identidade histórica de cada educando. O projeto Resgatando Nossa História visa justamente auxiliar na compreensão da identidade histórica e no papel de cada membro na comunidade e para que cada um se sinta protagonista da história. Com a história local, a interação com os alunos fica mais fácil, já que ela está presente no cotidiano, como relata o historiador Raphael Samuel:

A História Local requer um tipo de conhecimento diferente daquele focalizado no alto nível de desenvolvimento nacional e dá ao pesquisador uma ideia mais imediata do passado. Ela é encontrada

\footnotetext{
${ }^{66}$ Pós-graduando do curso de Especialização em Metodologias Ativas e o uso das TDIC's em Sala de Aula pela Universidade Pitágoras (UNOPAR). Professor de História, Secretaria de Estado da Educação de Santa Catarina/RS. Email: Guilherme.nutty98@gmail.com.
} 


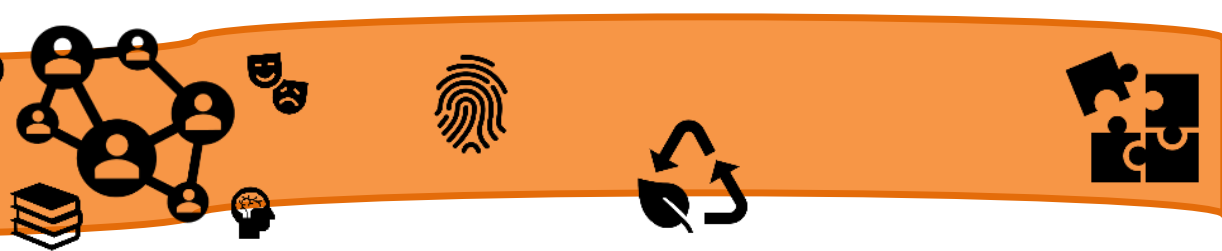

As fontes contribuem para a parte do projeto em que se trata sobre a evolução agrícola e a realidade das famílias. Nesta parte da realidade familiar, os alunos levaram para casa um questionário aos pais e avós sobre a visão que tinham da comunidade, como era atividade agrícola, quais produtos eram produzidos em ambas as perguntas deveria se comparar à resposta com a realidade atual.

Terminada a coleta de dados, foi elaborado um material que foi disponibilizado na biblioteca da escola para ser estudado por futuros discentes.

\section{RESULTADOS}

Quanto aos resultados alcançados em cada etapa do projeto de pesquisa, pode se salientar que, a escola se localizava em outro lugar distante cerca de cem metros de onde hoje ela se localiza, os alunos recebiam castigos físicos e as formações para professores ocorriam em Concórdia (na época).

Todos esses fatos concluídos após análises de diferentes escolas quanto a parte da realidade das famílias, observou-se uma diferença entre a quantidade de produtos produzidos na época. Há uma diferença em uso de maquinários, em técnicas de produção, inclusive a distância para onde os produtos eram levados, pois era maior. Diante da análise das semelhanças e diferenças dos últimos 80 anos na produção agrícola, foi possível construir uma linha do tempo do desenvolvimento agrícola em todo o oeste catarinense.

Conforme os registros feitos pelo professor Claudino Locatelli no ano de 1985 (LOCATELLI, 1985), e analisados para a pesquisa é possível observar que as comunidades do município de Ipumirim surgiram em meio às matas. Ipumirim possui uma história parecida com a de muitos outros municípios da região e intimamente ligada aos desdobramentos da construção da ferrovia São Paulo/Rio Grande e da Guerra do Contestado.

Passados os anos de chumbo e disputas por áreas em litígio, ao final da segunda década do século XX, a criação dos municípios de Chapecó e Cruzeiro (hoje Joaçaba), pelo então governador de Santa Catarina Filipe Schmidt impulsionou o desenvolvimento de todo o oeste catarinense. Neste contexto, empresas colonizadoras através de concessões do governo começam a divulgar terras produtivas e muitas delas jamais trabalhadas, no estado do Rio Grande do Sul, atraindo muitos colonos que 
enfrentavam a escassez de terras no estado vizinho. Dentre as empresas cabe destaque a Sociedade Territorial Mosele, Eberle e Ahrons \& Cia. Ltda., empresa que ficou com a concessão de uma área de aproximadamente $1100 \mathrm{~km}^{2}$, que ficou conhecida com Gleba Rio Engano, posteriormente divididas em lotes de 10 alqueires, equivalente a $240.000 \mathrm{~m}^{2}$ conhecidos como colônias.

Ao final do ano 1927 após medidas, as terras começaram a ser comercializadas aos colonos gaúchos que ao chegarem visitavam a sede Harmonia, futura sede do município e uma das sedes de povoamento, juntamente com as vilas que posteriormente seriam as maiores comunidades do interior do município de Bom Retiro (hoje Bom Sucesso) Bonito e São Rafael, onde a escola se localiza. Fato que ajuda a explicar o porquê os terrenos nos arredores da escola estão divididos como lotes urbanos, constituindo uma vila.

Ao comprarem terrenos agrícolas, os colonos precisavam desmatá-los e abrir acessos entre a mata até seu terreno, e acesso a outros terrenos, portanto, os primeiros anos de produção agrícola no interior de Ipumirim exigia muito esforço físico e a produção inicial era voltada a subsistência da família. A primeira atividade comercial foi a extração da madeira, a retirada da mata possibilitou a abertura de áreas de plantio de cereais principalmente o milho, utilizado também para o início de uma atividade pecuária que foi intensamente praticada na região e ainda tem uma representatividade grande na renda dos agricultores, a suinocultura.

Impulsionada a partir do ano 1944 com a fundação da SADIA, no município de Concórdia, município em que a região de Ipumirim fazia parte na época, e que devido a atividade da suinocultura e cultivo dos cereais estava entre os dez mais prósperos do estado. A SADIA é o marco inicial do crescimento das atividades agrícolas no município de Concórdia. Em 1963, Ipumirim é desmembrado de Concórdia e torna-se um município, herdando a estrutura já criada para ligar os produtores ipumirinenses à SADIA.

Durante longos anos a suinocultura e a produção de cereais foram o carro chefe da economia local, porém com algumas crises e o advento da tecnologia, os produtores passaram a diversificar as atividades nas propriedades rurais, como por exemplo, a produção de leite em grande escala, que só foi possível no interior de Ipumirim a partir da chegada da energia elétrica na zona rural. Anterior a isso, a produção de leite era uma 
atividade de subsistência devido às dificuldades em armazenar o produto in natura, já que o mesmo é muito perecível.

Além do advento da produção leiteira, surgiram os programas de integração das agroindústrias. $\mathrm{O}$ sistema de integração consiste em uma parceria entre agroindústria e produtor rural, onde o produtor entra com a estrutura física e a mão de obra e a agroindústria com os animais (suínos ou aves), medicamentos e alimentação. Ao término de um determinado período, o chamado lote, a empresa recolhe os animais prontos para o abate e remunera o produtor de acordo com os índices atingidos durante o período, analisando conversão de alimentação em peso, mortalidade e sanidade dos animais.

O sistema de integração fez muito sucesso entre os produtores pela garantia de saída dos animais da propriedade, não ter a necessidade de buscar a venda dos animais, os custos são reduzidos, o risco de prejuízo é menor e a agroindústria oferece todo suporte técnico. O sistema de integração teve um salto no município de Ipumirim, principalmente na avicultura, com a instalação em meados dos anos de 1990, de um frigorífico de abate de aves conhecido como Agrofrango, sendo que hoje ele é de propriedade do Grupo JBS.

Essa evolução resulta no perfil de propriedades rurais existentes hoje, com atividades diversificada, muitas voltadas ao mercado externo e algumas empregando as mais novas tecnologias para melhoramento e aumento da produção agrícola.

\section{CONCLUSÕES}

Através do conhecimento histórico adquirido pelos discentes, foi possível que cada um compreendesse sua importância e de suas famílias na construção da comunidade, sendo assim, construindo também sua identidade histórica.

Ao se estudar as mudanças na maneira de se produzir e a evolução das ferramentas de trabalho, os alunos puderam perceber nitidamente as evoluções ocorridas nos últimos anos nas técnicas e na quantidade de produtos produzidos pelas propriedades, também puderam perceber a diferença na rentabilidade, no cotidiano e até no tamanho das famílias e a necessidade de mão de obra.

A pesquisa em campo, bem como as entrevistas para obtenção de fontes históricas de natureza oral, foi muito produtiva, levando em consideração que os 


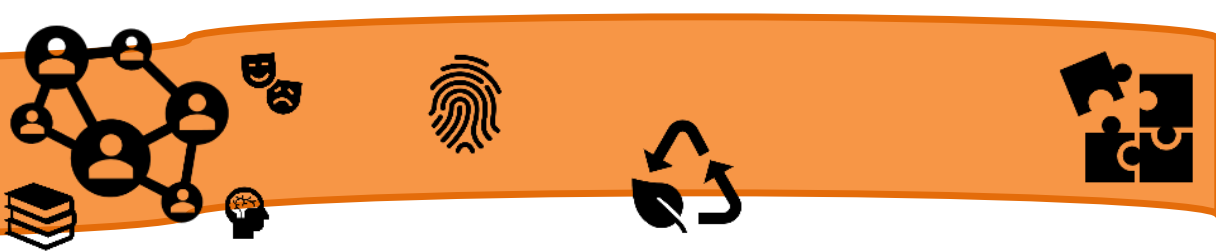

discentes buscaram fontes orais em seu próprio círculo familiar, como os avós, sendo que Ipumirim é um município relativamente novo, muitos que viveram as mudanças e fatos históricos do município ainda vivem e estão lúcidos e aptos a repassar informações sobre suas vivências.

Há proximidade das histórias das famílias com os registros históricos oficiais do município, ou seja, fontes de origem escrita. A ligação entre as fontes para formular uma teoria histórica, foi fundamental para a compreensão de como funciona o trabalho do historiador. Durante o desenvolvimento do trabalho os discentes viveram as fases de análise minuciosa das fontes históricas primárias e secundárias e através de orientação, puderam chegar a conclusões sobre o processo histórico da comunidade onde a escola está inserida, além da compreensão de aspectos sociais e econômicos intimamente ligados às suas vidas e sua convivência social.

Zamboni (1993, p. 7) em artigo publicado sobre o papel da História na construção da identidade, afirma que:

[...] o objetivo fundamental da História no ensino fundamental, é situar o aluno no momento histórico em que vive [...]. O processo de construção da história de vida do aluno, de suas relações sociais, situado em contextos mais amplos, contribui para situá-lo historicamente em sua formação social, a fim de que seu crescimento social e afetivo desenvolva-lhe o sentido de pertencer.

O fato de buscar a evolução da agricultura foi um dos fatores relevantes para despertar o interesse dos alunos, pois a atividade agrícola além de ser a fonte de renda da maioria dos discentes, já que se trata de um trabalho desenvolvido em uma escola do campo, é parte das atividade diárias dos alunos que já desempenham funções nas propriedades rurais pertencentes às suas famílias.

Essa proximidade dos discentes com o tema abordado pela pesquisa foi fundamental para a compreensão da importância do estudo da história, para que os mesmos desenvolvessem sua identidade histórica e também fundamental para criar a consciência nos discentes de que todas as pessoas são protagonistas da história.

\section{REFERÊNCIAS}

LOCATELLI, Claudino. O Município de Ipumirim: Estudo Histórico e Político, $1^{\text {a }}$ Edição, Ipumirim-Santa Catarina, Prefeitura Municipal de Ipumirim, janeiro de 1985. 
SAMUEL, Raphael. História Local e História Oral. In: Revista Brasileira de História. Pp. 219-242. V. 9, n. ${ }^{\circ}$ 19, set. 1989 / fev. 1990

ZAMBONI, Ernesta. O Ensino de História e a Construção da Identidade. História Série Argumento. São Paulo: SEE/Cenp, 1993. 

desenvolvimento no processo de ensino aprendizagem, propondo situações reais e permitindo que o docente construa um olhar sobre sua prática pedagógica, de forma a perceber possíveis fatores que favorecem este fracasso escolar.

De acordo com Neves (1992 apud Possa, 2000, p. 19):

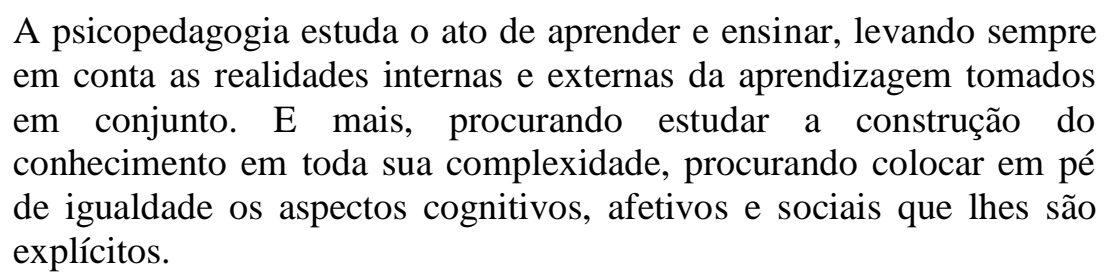

Tais aspectos pessoais e sociais podem influenciar nas possíveis limitações de aprendizagem que os discentes dispõem no cotidiano escolar. A pedagogia, por sua vez, auxilia na ação pedagógica com subsídios que cooperam de forma sólida, com estratégias que facilitem o desenvolvimento na aprendizagem da criança, em relação às suas dificuldades.

A psicopedagogia surge da necessidade de compreender o processo educacional de maneira interdisciplinar, buscando para este desafio fundamentos na pedagogia, na psicologia e em diferentes áreas de atuação. Podem ser muitas as razões que determinam o sucesso ou fracasso escolar de uma criança, como: fatores fisiológicos, psicológicos, sociais ou pedagógicos.

Seu objeto de estudo são os atos de aprender e ensinar, levando em conta o ser que aprende, ensina, modifica e é modificado, em sua singularidade. Os atos de aprender e ensinar estão tão interligados que não é possível mais separá-los dentro do processo educacional. Ela se propõe a identificar os pontos que possam, porventura, estar travando essa aprendizagem; atuar de maneira preventiva para evitá-los e, ainda, propiciar estratégias e ferramentas que possibilitem facilitar esse aprendizado.

De acordo com Nádia Bossa (2000, p. 23), cabe ao psicopedagogo "saber como se constitui o sujeito, como este se transforma em suas diversas etapas de vida, quais os recursos de conhecimento de que ele se dispõe, e a forma pela qual produz conhecimento".

A psicopedagogia também tem o papel importante em um novo momento educacional, que é a inserção dos alunos com necessidades educativas especiais no ensino regular, chamada Inclusão. Sua permanência e sucesso escolar, faz-se premente a 
necessidade de um acompanhamento e estimulação destes alunos para que as suas aprendizagens sejam efetivas.

O campo de atuação da psicopedagogia tem sido ampliado, o que, inicialmente, era caracterizado somente no aspecto clínico, hoje pode ser aplicado no segmento escolar e ainda em outros segmentos. A psicopedagogia institucional faz um trabalho preventivo, seu foco são as escolas e organizações educacionais e está mais voltada para a prevenção dos insucessos relacionados à aprendizagem dos alunos.

A psicopedagogia na instituição, não se ocupa exclusivamente de um indivíduo, e sim, do funcionamento em geral, do processo e dos resultados do aprender em seu interior e de modo como tudo isso pode estar contribuindo para o aparecimento de dificuldades e/ou facilidade de aprendizagem, isto é, sem desvincular-se da concretude de sua origem e de sua história.

Hoje, a psicopedagogia trabalha com uma concepção de aprendizagem com um equipamento biológico, com disposições efetivas e intelectuais que interferem na forma de relação do sujeito com o meio, sendo que essas disposições influenciam e são influenciadas pelas condições socioculturais do sujeito com o meio.

Sua origem deu-se na Europa no séc. XX, onde foram verificados os problemas de aprendizagem. Nesse século, tínhamos o avanço do capitalismo industrial e com ele os ideais burgueses de igualdade e fraternidade, o que ficava mais distante à possibilidade de uma sociedade fraterna e igual para todos. Ao longo do séc. XIX surgem teorias relacionadas à ciência e à teoria evolucionista de Charles Darwin, que enquadra o homem dentro do esquema da evolução biológica, abolindo as linhas divisórias das ciências naturais, humanas e sociais (BOSSA, 2007).

Finalmente no ano de 1948, o termo psicopedagogia passa a ser definido com o objetivo de atender crianças e adolescentes desadaptados, embora inteligentes, tinham dificuldades.

O objetivo do tratamento psicopedagógico é o desaparecimento do sintoma e a possibilidade do sujeito aprender normalmente em condições melhores enfatizando a relação que ele possa ter com a aprendizagem, ou seja, que o sujeito seja o agente da sua própria aprendizagem e que se aproprie do conhecimento (BOSSA, 2007, p. 21). 


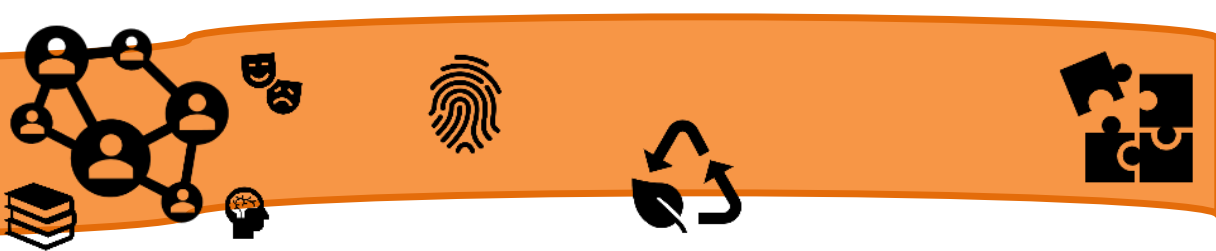

O movimento da psicopedagogia no Brasil remete ao seu histórico na Argentina, devido ao acesso fácil à literatura. As ideias argentinas tem influenciado a prática dos brasileiros. Antigamente, os problemas de aprendizagem eram considerados como fatores orgânicos e determinavam a forma de tratamento, inclusive no Brasil.

No início da década de 80 , começa a se configurar uma teoria sociopolítica a respeito do problema de aprendizagem escolar, que passou a ser chamado de problema de ensinagem. Em 1970, surgiram os primeiros cursos de Especialização em psicopedagogia no Brasil, idealizados para complementar a formação dos psicólogos e educadores que buscavam solucionar certos problemas. Eles foram estruturados com base em conhecimentos científicos e dentro de um contexto histórico.

\section{AÇÃO DOCENTE FRENTE AO ALUNO AGRESSIVO}

Muitos estudos têm enfocado manifestações de queixa entre os professores, trazendo-lhes sofrimento com as agressões físicas e verbais entre alunos, e as agressões verbais dirigidas diretamente aos professores.

Nessa perspectiva, destaca-se o trabalho de Tricoli (2002), que avalia o estresse dos professores como resultado de uma postura agressiva em sala de aula. A autora afirma que docentes agressivos, que gritam para colocar ordem na classe, inspiram comportamentos semelhantes em seus alunos. Assim, após um período de convivência, os alunos assumem atitudes tão agressivas quanto aquelas adotadas por seus professores ou apresentam comportamentos mais retraídos, em virtude do medo de punição.

Os docentes mostram-se inábeis perante a emergência de comportamentos problemáticos, recorrendo costumeiramente a uma atitude punitiva, "parecendo não saber como intervir de forma adequada" (ROYER, 2003, p. 60). Para Silva (2006), a exemplo dos alunos considerados agressivos, os professores também manifestam sua agressividade através de diferentes formas de evasão, com seu desinteresse pelo trabalho, acomodação, mudança de escola, abandono do emprego e até da profissão.

Deste modo, constata-se que, se por um lado há convergência na percepção do que é vivenciado como expressão agressiva pelos docentes, por outro também é possível observar certa impotência e despreparo em relação ao manejo destas manifestações. A agressividade infantil, ainda que reflita a esperança de suprir necessidades muito precoces, também provoca hostilidade, desejos de retaliação ou mesmo de evasão por 


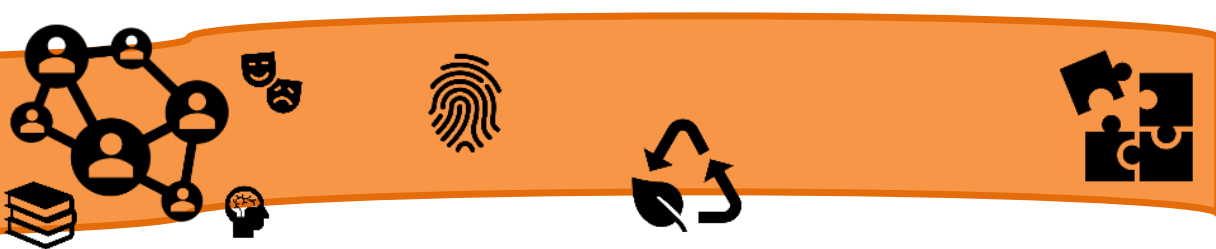

parte dos professores, o que demanda um aprofundamento sobre as atitudes que os docentes assumem em sala de aula ao interpretarem as atitudes infantis como agressivas.

Dentro de uma instituição educacional, o professor é quem lida diretamente com o aluno, é aquele que observa atitudes, detecta problemas, portanto, não deve negar assistência ao aluno que frequentemente torna-se vítima de atos agressivos. É preciso interferir, porque quando o professor não toma nenhuma atitude, os estudantes podem interpretar o fato como aprovação e a situação tende a se agravar.

Reconhecendo que a escola depois da família é o local onde o jovem agressivo pode ser ajudado, a orientação educacional assume a função de sensibilizar todo o corpo docente, além de atender, amenizar e buscar soluções para ajudar o aluno agressivo. Ela lida com o conflito já pronto, assume o papel de orientar um trabalho conjunto com a coordenação pedagógica e com o corpo docente.

O diálogo é um instrumento importantíssimo nesses casos, mas muitas vezes a escola chama o aluno agressor e numa comunicação unilateral, impõe as punições contidas num regimento escolar. Ao contrário disso, não eximindo o aluno de ser punido, é importante fazer uma reflexão acerca do ocorrido e se for frequente e o jovem se fechar ao diálogo, é preciso reconhecer a possibilidade de um acompanhamento específico.

Expulsar o aluno, sucessivamente, de nada adianta. Deixar de reagir de forma assustada e acuada, passando a atuar de modo pensado e refletido, analisando o aluno, a frequência de atos agressivos e repensando, muitas vezes, se a escola não está só cumprindo um programa de disciplina que privilegie o proibido e a punição. Faz-se necessário construir um conjunto de regras claras e transparentes que ordenam as relações, enxergando o conflito como inerente aos grupos sociais diferentes que habitam o mesmo espaço.

\section{PREPARO DO PROFESSOR PARA LIDAR COM O ALUNO-PROBLEMA}

Para muitos, é certo que as questões que enfrentamos na educação brasileira têm relação imediata com a atuação do professor. Mas quando existe a proposta de pesquisar as razões dos fracassos escolares que rondam nossa sociedade, vemos despontando um conceito muito polêmico: o de aluno-problema. $\mathrm{O}$ aluno-problema é aquele que padece 


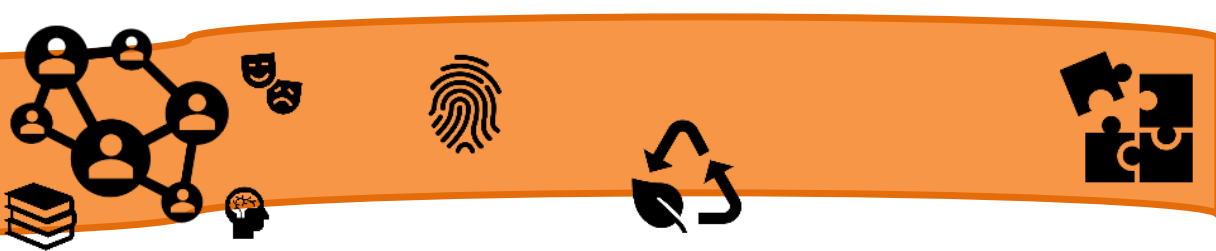

de certos distúrbios, que podem ser de natureza cognitiva (distúrbios de aprendizagem) ou de natureza comportamental (a indisciplina).

É preciso que o professor compreenda que o aluno-problema é um porta-voz das relações estabelecidas em sala de aula e que a imagem de aluno ideal, do modo como ele deveria ser e dos hábitos que ele deveria cultivar, deve ser abandonada. Em relação à prática, o objetivo da ação do trabalho docente deve ser o compromisso com o conhecimento; e a experimentação de novas estratégias de trabalho e investigação da prática. Pois, se há fracasso, o fracasso é de todos. O mesmo acontece com o sucesso escolar.

Uma questão importante, por exemplo, é quando o professor acha que o aluno tem uma postura inadequada, porque ele pertence a uma família desestruturada. "Ora, isso é possível, mas quanto mais o professor idealiza o aluno ideal, a família ideal, as condições ideais de ensino, mais ele se deprime com a realidade que encontra em sala de aula", explicou Santos (2001).

No cotidiano escolar, sabe-se que as relações interpessoais não são sempre positivas. A violência crescente na sociedade ultrapassa os muros escola adentro. Além disso, o contexto social, político e econômico brasileiro em que a escola está inserida, contribuem para o estabelecimento de relações interpessoais desfavoráveis.

De acordo com Santos (2001) "a idealização é importante porque o professor precisa acreditar no poder que a educação tem de ajudar a promover o desenvolvimento do ser humano. Por outro lado, essa idealização traz problemas porque ele idealiza uma situação que não existe".

\section{CONSIDERAÇÕES FINAIS}

Um dos principais desafios encontrados pelo educador está no comportamento do aluno. De atitudes inadequadas à conflitos diretos com colegas de classe e professores, surgem algumas das maiores preocupações vivenciadas pela escola atualmente.

Aumento de atitudes agressivas, atos violentos, transgressão de regras, violação dos direitos alheios, entre outras manifestações antissociais no ambiente escolar, evidenciam importantes desajustes na relação educador/aluno. O educador, diante de tal situação, necessita conhecer as causas e consequências destes problemas para, então, 


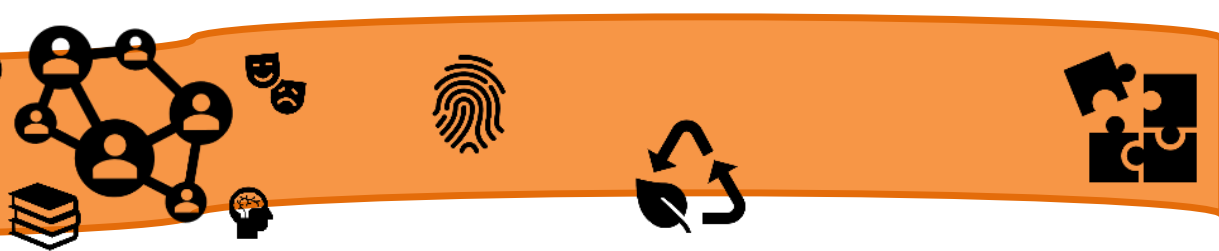

buscar soluções e evitar o agravamento e a disseminação deste padrão de comportamento, passando do âmbito individual para o coletivo.

O enfraquecimento da relação aluno/educador, falhas no processo educativo, perda do referencial de autoridade no ambiente escolar e o inquestionável agravamento das barreiras encontradas por todos os envolvidos neste processo, são apenas as mais evidentes. Tal é a gravidade destes problemas, que estas consequências não se limitam ao ambiente escolar, mas se traduzem em sérios reflexos sociais.

O que deve ser buscado gradualmente é a identificação dos fatores causais, o fortalecimento dos agentes implicados em todo o processo, a ampliação dos espaços e possibilidades de reflexão e discussão, buscando a melhoria das condições de ensino.

Neste processo, uma importante estratégia é a de potencializar sua capacidade em motivar seu aluno e despertar seu interesse pela busca do saber, oferecendo novas possibilidades de adquirir conhecimento e superar barreiras.

Evitar o confronto direto com o aluno é fundamental para preservar qualquer possibilidade de reestruturação de um relacionamento já comprometido. Para isto, é importante que o educador perceba que a manifestação agressiva, em geral, não tem como causa o próprio educador ou qualquer divergência pessoal por parte do aluno, mas é um reflexo das barreiras encontradas por este em seu desenvolvimento emocional, cognitivo e social.

Ajudar o aluno a potencializar seus recursos internos, valorizar qualquer possibilidade de esforço ou conquista, promover o diálogo e buscar ajuda externa, quando a situação demonstra sinais de agravamento, são algumas das ferramentas que o educador dispõe. Além disso, o professor pode gerar uma reflexão entre os alunos sobre as questões que envolvem comportamentos, conflitos e atitudes inadequadas, possibilitando o envolvimento dos jovens na construção de soluções. Faz parte da missão do educador e da instituição de ensino garantir às possíveis vítimas de atitudes agressivas, o suporte necessário para a solução de problemas.

Um ponto deve ser fortemente valorizado e explorado: a importância do papel do educador, não apenas diante de comportamentos inadequados, como também diante da possibilidade de tornar-se um agente transformador no desenvolvimento de seu aluno.

Uma das maneiras de tornar um aluno questionador, crítico e parceiro de sala de aula, muitas vezes mal visto pelo educador, é oferecendo espaço e atenção, além de 
motivação. O professor deve valorizar o saber deste aluno, instigar sua curiosidade, propor diferentes formas de aquisição do aprendizado e estimular a pesquisa e investigação. Deste modo, a simples transferência de conhecimento é evitada e o aluno sai da posição de mero receptor de informações, transformando-se em parceiro.

Sendo assim, nos leva a refletir sobre a grandeza e a complexidade do papel do educador, sobre os desafios a que é submetido diariamente, sobre a necessidade de sua capacitação e atualização constantes, sobre a influência de suas ações e sobre a cautela necessária em sua atuação.

\section{REFERÊNCIAS}

BOSSA, Nadia. A psicopedagogia no Brasil: contribuições a partir da prática. Rio de Janeiro: Artmed, 2007.

BOSSA, Nádia. A psicopedagogia no Brasil: contribuições a partir da prática. 2. ed. Porto Alegre: Artmed, 2000.

LOMONICO, Circe. Psicopedagogia: teoria e prática. 2. ed. São Paulo: Edicon, 2005.

ROYER, E. Condutas agressivas na escola: pesquisas, práticas exemplares e formação de professores. Em Unesco (Org.), Desafios e Alternativas: violência nas escolas, Brasília: Unesco, 2003.

SANTOS, Thais Helena dos. Aluno problema: um desafio que vale a pena. Educabrasil. São Paulo: Midiamix, 2001. Disponível em: <https://www.educabrasil.com.br/aluno-problema-um-desafio-quevale-a-pena/>. Acesso em: 13/04/2020.

SILVA, M. E. P. Burnout: por que sofrem os professores? Estudos e Pesquisas em Psicologia, 2006.

TRICOLI, V. A C. O papel do professor no manejo do stress do aluno. Em M. E. N. Lipp (Org.). O stress do professor (pp. 90-106). Campinas: Papirus, 2002. 



\section{SOBRE OS AUTORES}

ALVES, Laurenita Gualberto Pereira: Mestranda em Educação pela Universidade Federal do Tocantins (UFT). Especialista em Gênero e Diversidade na Escola pela Universidade Federal do Tocantins (UFT). Especialista em Gestão, Orientação e Supervisão Escolar pela Faculdade João Calvino. Graduada em Normal Superior pela Universidade do Tocantins (UNITINS). Bacharela em Administração Pública pela Universidade Federal do Tocantins (UFT/UAB). Professora da Rede Estadual, atualmente está desempenhando a função de Assessora de Educação de Jovens e Adultos, Campo e Quilombola, lotada na Diretoria Regional de Ensino de Dianópolis/TO. É membro da Comunidade Quilombola de Lajeado- Dianópolis/TO. Faz parte da Diretoria Executiva da Associação da comunidade atuando como Secretária Geral. É integrante do Grupo de Pesquisa em Democracia e Gestão Social da UNESP (GEDGS). Integrante da Rede Internacional de Pesquisadores sobre Povos Originários e Comunidades Tradicionais - RedeCT (com sede na UNESP). Tem interesse em temáticas ligadas às questões étnicas raciais. Tem experiência na área de Educação.

ALVES, Sabrina Sacoman Campos: Doutora em Educação pela Universidade Estadual Paulista Júlio de Mesquita Filho - UNESP/Marília-SP e Mestre em Educação pela mesma Universidade. Graduada em Pedagogia também pela Universidade Estadual Paulista Júlio de Mesquita Filho (UNESP). Graduada em Letras pela Faculdades Adamantinenses Integradas (FAI). É integrante do Grupo de Estudo e Pesquisa em Epistemologia Genética e Educação - GEPEGE (Unesp - Marília/SP), desde 2009. Atua como Coordenadora Pedagógica da Educação Infantil e $1^{\circ}$ ano do Ensino Fundamental, em escola da rede particular de ensino em Marília/SP, desde 2013.

ALVES, Solange Maria: Doutora em Educação com área de concentração em psicologia e educação pela Faculdade de Educação da Universidade de São Paulo (FEUSP). Mestra em Educação pela Universidade Estadual do Centro Oeste em convênio com UNICAMP, com área de concentração em Metodologia de Ensino. Especialista em Educação Especial pela Universidade do Oeste de Santa Catarina (UNOESC). Graduada em Pedagogia pela Universidade do Oeste de Santa Catarina (UNOESC). Atuou como professora titular da Universidade Comunitária Regional de Chapecó. Atuou como consultora educacional pela Secretaria de Estado da Educação e do Desporto de Santa Catarina. Possui experiência na área de Educação, com ênfase em Formação de professores, Teorias da Instrução, Metodologia de ensino, educação e desenvolvimento humano na perspectiva histórico-cultural, Pedagogia freireana, atuando principalmente nos seguintes temas: aprendizagem, desenvolvimento $\mathrm{e}$ educação na concepção histórico-cultural, práxis pedagógica, método dialético de construção do conhecimento e organização escolar. Possui experiência em gestão educacional no âmbito da educação superior, atuando como coordenadora de curso de graduação e pós-graduação stricto sensu; vice-diretora, pró-reitoria de graduação. Atuou como coordenadora do PIBID. Possui experiência em assessoria pedagógica aos cursos de formação superior na área da saúde, bem como com organização curricular e formação permanente em Secretarias Municipais de Educação da região oeste de SC. Atualmente é professora do curso de Pedagogia e do Programa de Pós-Graduação em Educação - Mestrado em Educação da Universidade Federal da Fronteira Sul (UFFS) 
atuando em projetos de extensão e pesquisa em educação. É líder e pesquisadora do Grupo de Pesquisa Escola de Vigotski (GEPEVI) vinculada a Universidade Federal da Fronteira Sul (UFFS).

ANDRADE, Luciana Vieira: Doutoranda em Educação Matemática pela Universidade Estadual Paulista (UNESP/Rio Claro). Mestra em Ensino de Ciências Naturais e Matemática, pelo PPgECNM, da Universidade Federal do Rio Grande do Norte (UFRN). Graduada em Licenciatura em Matemática pela Universidade Federal do Rio Grande do Norte (UFRN). Foi bolsista do PET (CAPES). Tem participado de diversos eventos Nacionais e Internacionais da área de Educação Matemática. É docente do quadro efetivo da Secretaria de Estado da Educação e da Cultura do Rio Grande do Norte. Está atuando como professora Formadora e Redatora do currículo de Matemática do Ensino Fundamental, pelo Programa de apoio à implementação da Base Nacional Comum Curricular (PROBNCC), junto ao MEC. Foi preceptora voluntária do Programa Residência Pedagógica (PRP), subprojeto Matemática pela Universidade Federal do Rio Grande do Norte (UFRN). Atuou como professora substituta no Bacharelado em Tecnologia da Informação, do Instituto Metrópole Digital da UFRN. Foi professora supervisora do Programa Institucional de Bolsas de Iniciação à Docência (PIBID), subprojeto Matemática da UFRN. Vivenciou a experiência de atuar como tutora à distância do curso de Especialização em Ensino de Matemática no Ensino Médio da Secretaria de Educação à Distância (SEDIS) da UFRN e como professora orientadora de trabalhos de conclusão de curso desta mesma especialização. Tem experiência na área de ensino de Matemática na Educação Básica desde 1998, tendo sido professora do Ensino Médio Integrado do Instituto Federal de Educação, Ciência e Tecnologia (IFRN), da Fundação Bradesco. No Ensino Superior, além da UFRN, lecionou no IFRN, na Faculdade de Natal (FAL) e na Faculdade de Excelência Educacional do Rio Grande do Norte (FATERN).

AQUINO, Daliene Patrícia Ribeiro De: Mestranda do Curso de Ciências da Educação pela Faculdade do Estado do Maranhão (FACEM). Especialista em Psicopedagogia institucional clínica e hospitalar pela Faculdade do Complexo Educacional Santo André (FACESA). Especialista em Alfabetização e Letramento, Especialista em Educação Especial e Especialista em Educação Infantil pela Faculdade Venda Nova do Imigrante (FAVENI). Graduada em Licenciatura em Pedagogia pelo Instituto de Ensino Superior Múltiplo (IESM). Professora da Educação Básica do Município de Guamaré/RN.

BARROS, Luzani Cardoso: Mestra em Desenvolvimento Regional e Agronegócio pela Universidade Federal do Tocantins (UFT). Especialista em Conselho Escolar pela Universidade Federal do Ceará (UFC). Especialista em Gestão Escolar pela Universidade Federal do Tocantins (UFT). Especialista em Tecnologias Educacionais pela Pontifícia Universidade Católica do Rio de Janeiro (PUC-Rio). Especialista em Gestão Educacional e Metodologia do Ensino pela Sociedade de Educação Continuada (EDUCON). Especialista em Língua Portuguesa pela Faculdades Integradas de Amparo/SP (FIA). Graduada em Licenciatura em Pedagogia pela Universidade do Estado da Bahia (UNEB). Atua na área educacional desde 1996, quando concluiu o Curso Magistério, em nível Médio. De julho de 2014 a dezembro de 2018 compôs o quadro docente da Universidade Estadual do Tocantins, Campus Dianópolis. Na 
SEDUC/TO atuou como membro da equipe técnica da Coordenadoria de Tecnologia da Educação onde desenvolve funções até hoje.

BENVENUTTI, Guilherme Renan: Pós-graduando do curso de Especialização em Metodologias Ativas e o uso das TDIC's em Sala de Aula pela Universidade Pitágoras (UNOPAR). Possui graduação em História pela Universidade Pitágoras (UNOPAR). Atualmente é professor da Secretaria de Educação do Estado de Santa Catarina. Tem experiência na área de História. Graduando do Curso superior de Tecnologia em Gestão Pública pela UNIFACVEST. Professor da Secretaria de Estado da Educação de Santa Catarina, desde 2017.

BERNARDINO, Maria Lucivania Da Silva: Graduada em Ciências Contábeis pela Universidade Federal da Paraíba (UFPB). Graduada em Letras Língua Portuguesa pela Universidade Federal da Paraíba (UFPB). Atualmente exerce a função de contadora.

BEZERRA, Raíres Lauane De Lima: Graduanda do curso de Bacharelado e Licenciatura em Enfermagem da Universidade do Estado do Rio Grande do Norte (UERN). Participou no projeto de pesquisa na área de saúde coletiva com ênfase em políticas públicas de saúde, denominado "Estilo de vida na terceira idade: um estudo no sertão nordestino" da Faculdade Evolução Alto Oeste Potiguar (FACEP). Publicou, como autora, o artigo "Participação popular: uma estratégia de controle na saúde" em conjunto com alunos do curso de Enfermagem da FACEP.

BIANCHINI, Giovana: Doutora em Desenvolvimento Regional pela Universidade de Santa Cruz do Sul (UNISC). Mestre em Administração pela Universidade Federal de Santa Maria (UFSM). Especialista em Gerenciamento Estratégico Empresarial pela Universidade Federal de Santa Maria (UFSM). MBA em Estratégia e Finanças pela Universidade Federal de Santa Maria (UFSM). Possui Graduação em Administração de Empresas pela Universidade Federal de Santa Maria. Tem experiência na área de Educação, com ênfase em Ensino-Aprendizagem, atuando principalmente nos seguintes temas: Desenvolvimento Regional, Estratégia, Marketing e Gestão Financeira. Professora Instituto Federal de Educação, Ciência e Tecnologia do Rio Grande do Sul (IFRS).

CARDOSO, Samara Fortunato: Graduada em Enfermagem pela Universidade Federal do Rio Grande do Sul (UFRGS). Residente de Enfermagem em OncoHematologia da Universidade Federal de Santa Maria (UFSM).

CARVALHO, Midiã Ester Santos De: Graduanda em Licenciatura Plena em Ciências Naturais - Biologia pela Universidade do Estado do Pará (UEPA). Foi bolsista do PIBIC no grupo CETENF e IEC/PA. Possui experiência em Genética e Imunologia, Ensino de Ciências e Metodologias Alternativas.

COSTA, Ivanilson Sousa Da: Especialista em Esportes Coletivos na Escola pela Universidade do Estado do Rio Grande do Norte (UERN). Graduação em Educação Física pela Universidade do Estado do Rio Grande do Norte (UFRN). Professor de Educação Física do município de Macau/RN. 
DIAS, Vitória Holanda: Graduanda do curso de Bacharelado em Enfermagem da Faculdade Evolução Alto Oeste Potiguar (FACEP). Participou de projeto de pesquisa "Estilo de vida na terceira idade: um estudo no sertão nordestino". Publicou como coautora o artigo "participação popular: uma estratégia de controle na saúde" em conjunto com alunos do curso de Enfermagem da Faculdade Evolução Alto Oeste Potiguar (FACEP).

DONGO-MONTOYA, Adrian Oscar: Pós-Doutor pela Université Lumière De Lyon - França. Mestre e Doutor em Psicologia pelo Instituto de Psicologia da USP. Professor Titular da Faculdade de Filosofia de Ciências da UNESP - Campus De Marília. Professor Livre Docente do Departamento de Psicologia da Educação da Faculdade De Filosofia e Ciências da UNESP - Campus de Marília. Professor de PósGraduação Strito Sensu Nos Cursos de Mestrado em Filosofia, e de Doutorado em Educação. Publicou 03 Livros de Autoria Pessoal no Brasil e 02 no Exterior. Publicou muitos artigos em revistas conceituadas no Brasil e exterior e muitos capítulos de livros. Coautor na publicação de vários livros. É Coordenador do Grupo de Pesquisa "Epistemologia Genética e Educação". Foi presidente de $4^{\circ}$ Colóquios Internacionais em Epistemologia e Psicologia Genéticas.

DUARTE, Erica Rosalba Mallmann: Doutora em Engenharia da Produção pela Universidade Federal do Rio Grande do Sul (UFRGS). Mestra em Administração pela Universidade Federal do Rio Grande do Sul (UFRGS). Possui Graduação em Enfermagem e Obstetrícia pela Universidade do Vale do Rio dos Sinos (UNISINOS). Graduada em Licenciatura em Enfermagem pela Universidade Federal de Minas Gerais (UFMG). Professora Associada IV da Universidade Federal do Rio Grande do Sul Escola de Enfermagem (UFRGS). Professora da área de Administração na graduação e Estágio Curricular na Rede da Atenção Básica. Professora da Pós-Graduação em Saúde Coletiva. Coordenadora do Comitê de Ética do HMD. Diretora da Associação Brasileira de Enfermagem Nacional. Pesquisadora na área de Enfermagem e Saúde Coletiva.

DURO, Carmen Lúcia Mottin: Doutora em Enfermagem pela Universidade Federal do Rio Grande do Sul (UFRGS). Mestra em Enfermagem pela Universidade Federal do Rio Grande do Sul (UFRGS). Especialista em Saúde Comunitária pela Secretaria de Saúde do Estado do Rio Grande do Sul (SSSMA/RS). Especialista em Enfermagem do Trabalho pela Universidade Luterana do Brasil (ULBRA). Graduação em Enfermagem pela Universidade Federal do Rio Grande do Sul (UFRGS). Professora Adjunta Escola de Enfermagem. Professora disciplina Administração em Enfermagem na Graduação em Enfermagem- Escola de Enfermagem da UFRGS. Responsável atividade de Ensino Estágio Curricular Atenção Básica. Representante da Coordenadoria da Saúde da Universidade Federal do Rio Grande do Sul (UFRGS).

FAGHERAZZI, Onorato Jonas: Doutor em Educação em Ciências pela Fundação Universidade de Rio Grande (FURG). Mestre em Filosofia pela Universidade Federal do Rio Grande do Sul (UFRGS). Especialista em Psicologia pela Universidade Internacional Da Paz (UNIPAZ - Sul). Especialista em Educação de Adultos na Perspectiva da Educação Popular pela Universidade Federal do Rio Grande do Sul (UFRGS). Graduado em Filosofia pela Pontifícia Universidade Católica Do Rio Grande Do Sul (PUC-RS). Coordenador do Curso Técnico em Viticultura e Enologia Integrado 
ao Ensino Médio do Instituto Federal de do Rio Grande do Sul (IFRS) - Campus Bento Gonçalves.

FERREIRA, Maria De Fátima De Melo: Especialista em Atendimento Educacional Especializado (AEE) pela Faculdade Maciço de Baturité (FMB). Licenciada em Pedagogia pelo Instituto Superior de Educação de Pesquisa (ISEP/CE). Professora da Educação Básica.

FONSECA, Amazilene da Silva Aguiar: Mestranda em Ciências da Educação pela Absoulute Christian University. Especialista em Saberes e Práticas da Matemática pela Faculdade de Ciências de Wenceslau Braz (FACIBRA). Especialista em Gestão, Orientação e Supervisão Escolar pela Faculdade Rio Sono (SOBE). Graduada em Licenciatura em Matemática pela Faculdade Cidade de Guanhães (FACIG). Graduada em Licenciatura em Pedagogia pela Faculdade em Anglo Latino (FAL). Iniciou sua trajetória profissional em escolas privadas. Atualmente é professora da rede pública no Estado do Maranhão, atuando nas turmas de Ensino Fundamental II, com a disciplina de Matemática.

FREITAS, João Antônio Maia: Graduando do curso de Bacharelado e Licenciatura em Enfermagem da Universidade do Estado do Rio Grande do Norte (UERN). Realiza pesquisas na área de saúde coletiva com ênfase em políticas públicas de saúde. Participou como coautor de artigo em conjunto com alunos do curso de Enfermagem da Faculdade Evolução Alto Oeste Potiguar (FACEP).

GOMES, Kaio Anderson Fernandes: Graduado em Licenciatura Plena em Pedagogia pela Universidade Federal do Amazonas (UFMA). Participou dos projetos: Observatório da Educação do Campo; Cine Clube Itinerante; Cine Clube Instituto de Natureza Cultura em cena e projeto ludoteca. Atualmente é bolsista no programa residência pedagógica. Foi membro do Fórum Permanente de Educação a convite da secretaria municipal de educação - SEMED representado a comunidade acadêmica de graduação do Instituto de Natureza e Cultura - INC/UFAM. Coordenou o I Diálogo Intercultural Universitário - 2018. Foi membro do Conselho Diretor - CONDIR. Membro da comissão da SEMAPE - Semana de Pedagogia, membro da Comissão Setorial de Avaliação - CSA do Instituto de Natureza e Cultura - INC/UFAM. Membro do Conselho Superiores da Universidade Federal do Amazonas - 2019. Tem mais de 12 publicações de artigos/pôsteres científicos nos âmbitos nacionais e internacionais. Atualmente é assessor de Secretaria de Educação e Cursando pós-graduação em Gestão, Supervisão e Orientação Escolar/MA.

GOMES, Uerica Estevão: Graduanda do Curso de Ciências Biologia e Química pelo Instituto de Natureza e Cultura/INC - campus da Universidade Federal do Amazonas-UFAM.

KAEFER, Maria Teresinha Verle: Mestra em Educação pela Universidade Federal do Rio Grande do Sul (UFRGS). Especialista em Escola de Gestores pela Universidade Federal do Rio Grande do Sul (UFRGS). Especialista em Educação Profissional Técnica na Modalidade EJA pela Universidade Federal do Rio Grande do Sul (UFRGS). Especialista em Educação área de Séries Iniciais pela Universidade Regional Integrada do Alto Uruguai e das Missões (URI). Possui graduação em 
Pedagogia pela Universidade Regional do Noroeste do Estado do Rio Grande do Sul (1991). Atualmente é professora dos cursos de licenciaturas de Matemática e Física no (IFFar) - campus São Borja. Atua com cursos de formação de professores (extensão). Atuou como Diretora de Ensino do Instituto Federal Farroupilha. Integrante do CAEN comitê assessor de ensino do Instituto Federal Farroupilha. Presidente do NPI - Núcleo Pedagógico Integrado do Instituto Federal Farroupilha. Docente do Instituto Federal Farroupilha. Tem experiência na área de Educação, com ênfase em Ensino Profissionalizante, atuando principalmente nos seguintes temas: Educação de Jovens e Adultos, Educação Popular, PROEJA, Políticas Públicas, Educação Profissional e Formação de Professores.

LEMOS, Karina Dutra De Carvalho: Mestra em Modelagem Matemática e Estatística pela Universidade Vale do Rio Verde (UninCor). Possui graduação em Ciência da Computação pela Universidade Federal de Lavras (2001). Tem Licenciatura Plena em Matemática pela Universidade Vale do Rio Verde. Atualmente é professora do Instituto Federal de Minas Gerais (IFMG) - Campus São João Evangelista.

LOPES, Eldeline Nascimento: Graduanda em Licenciatura Plena em Ciências Naturais - Biologia pela Universidade do Estado do Pará (UEPA). Possui experiência na Coleção Zoológica, Ensino de Ciências na Amazônia e Metodologias Alternativas.

MACHADO, Alexander Da Silva: Mestre em Integração Latino-Americana pela Universidade Federal de Santa Maria (UFSM). Possui graduação em História pela Universidade Federal de Santa Maria (UFSM). Atualmente é Professor do Instituto Federal Farroupilha e Revisor de periódico da Revista Thema. Tem experiência na área de História, com ênfase em História da América; atuando principalmente nos seguintes temas: História, Integração, Educação.

MACHADO, Solange Aparecida: Mestranda do curso de Educação pela Universidade Federal do Tocantins (UFT). Especialista em Gestão Escolar e Metodologias do Ensino de História e Geografia pela Unitins/Educon. Especialista em Gestão Pública pela Universidade Aberta do Brasil (UAB). Formada em Pedagogia com Habilitação em Orientação Educacional pelo Centro Técnico Superior do Oeste Paranaense/CETSOP.

MAIA, Luiz Cláudio Gomes: Doutor em Ciência da Informação pela Universidade Federal de Minas Gerais (UFMG). Mestre em Ciências da Informação pela Universidade Federal de Minas Gerais (UFMG). Graduado em Letras com habilitação em Inglês pela Universidade Federal de Minas Gerais (UFMG). Graduação em Pedagogia pela Universidade do Estado de Minas Gerais (UEMG). Graduação em Ciência da Computação pela Faculdade de Ciências Administrativas e Econômicas de Minas Gerais (FACE/FUMEC). Graduado em Processamento de Dados pela Faculdade de Ciências Administrativas e Econômicas de Minas Gerais (FACE/FUMEC). Atualmente é professor da Universidade FUMEC em disciplinas dos cursos de graduação em TI e no programa de mestrado em Sistemas de Informação e Gestão do Conhecimento. Pesquisador do LAIS - Laboratory for Advanced Information Systems. Também é diretor da Alarmsoft Tecnologia em Segurança. Atuou em grandes empresas como Terra Networks, TOTVS, Pitágoras e Itambé. Atua principalmente nos 
seguintes temas: algoritmos computacionais, inteligência artificial, internet das coisas, tecnologia da informação, recuperação da informação e gestão do conhecimento.

MEDEIROS, Kássio Wagner Da Silva: Especialista em Metodologia do Ensino de Geografia e História pelo Centro Universitário Internacional (UNINTER). Especialista em Gestão da Educação Municipal pela Universidade Federal da Paraíba (UFPB). Possui Licenciatura em Letras com habilitação em Língua Portuguesa pela Universidade Estadual do Rio Grande do Norte (UERN). Graduada em Licenciatura em Geografia pela Universidade Federal do Rio Grande do Norte (UFRN). Ministra formações para professores da Rede Municipal de Ensino de Pendências/RN nas áreas de Língua Portuguesa e Geografia. Possui curso de correção de textos como também realiza trabalho de correção ortográfica e ABNT de artigos e monografias. É professor da Rede Estadual de Ensino do RN lotado na Escola Estadual Monsenhor Honório Pendências/RN.

MELO, Igor Alessandro Da Silva: Mestrando em Ciências da educação pelo Centro de Educação Continuada e Aperfeiçoamento Profissional (CECAP). Especialista em Gestão e Coordenação Pedagógica pelo Instituto Superior de Educação de Pesquisa (ISEP/CE). Especialista em Metodologia do Ensino da EJA pela Universidade Luterana do Brasil (ULBRA). Especialista em AEE e Educação Especial pela Faculdade do Vale Elvira Dayrell (FAVED). Especialista em Alfabetização e Letramento pela Faculdade do Vale Elvira Dayrell (FAVED). Especializando em Psicopedagogia Institucional, Clínica e Educação Especial pela Faculdade Venda Nova do Imigrante (FAVENI). Licenciado em Pedagogia pela Universidade Estadual Vale do Acaraú/CE (UVA). Professor da Educação Básica do município de Guamaré/RN.

MELO, Jakeline Olegário De: Especialista em Fisiologia do Exercício pelo Instituto de Educação de Pesqueira/PE (IESP). Licenciada em Educação Física Universidade do Estado do Rio Grande do Norte (UFRN). Professora de Educação Básica.

MELO, Janelene Rita Teixeira de: Mestranda no curso de Ciências da Educação pela Faculdade do Estado do Maranhão (FACEM). Especialista em Atendimento Educacional Especializado (AEE) pela Faculdade Do Vale Elvira Dayrell/MG. Especialista em Psicopedagogia pela Universidade Vale Do Acaraú/CE (UVA). Graduada em Pedagogia pela Universidade Vale Do Acaraú/CE (UVA). Professora da Educação Básica do município de Guamaré/RN.

MELO, Marycelia Bastos Da Silva: Mestranda em Educação pela instituição Revalide Educacional (REEDUC). Especialista em Práticas Educativas do Ensino Médio pela Faculdade de Natal (FAL). Especialista em Educação Especial e Inclusiva pela instituição Faculdade Futura (Instituto De Ciências, Educação e Tecnologia de Votuporanga). Licenciada Em Pedagogia pela Universidade Federal do Rio Grande do Norte (UFRN). Licenciada em Matemática pela instituição de Educação Superior Presidente Kennedy (Natal/RN). Tem experiência na área educacional há mais de vinte anos, com ênfase no ensino fundamental anos iniciais e EJA (Educação de Jovens e Adultos). Atualmente é professora da Educação Básica do município de Guamaré/RN. 
MONSALVE-CUARTAS, Ana Maria: Doutoranda do Curso de Florestas e Recursos Florestais (SUSFOR) na Universidade de Lisboa-Instituto Superior de Agronomia (ISA). Mestre em Estudos Urbano-Regionais da Universidade Nacional da Colômbia. Mestre em Arquitetura da Paisagem da Pontifícia Universidade Católica do Chile. Experiência profissional em projetos de Consultoria Florestal e Planejamento Territorial; Estudos de Impacto Ambiental; Gestão e Conservação de Bacias Hidrográficas; Ecologia da Paisagem; Sistemas florestais e agroflorestais; Inventários de Recursos Naturais; Formulação de planos de manejo florestal; Ensino de Pesquisa em Florestas, Silvicultura, Ecologia da Paisagem, Flora e Etnoecologia. Direção e júri de tese do Mestrado em Desenho de Paisagem da Universidade Pontificia Bolivariana. Engenheira Florestal - Portugal.

MOTA, Marinete Lourenço: Doutora em Sociedade e Cultura na Amazônia pela Universidade Federal do Amazonas (UFAM). Mestra em Educação pela Universidade Federal do Amazonas (UFAM). Especialista em Psicopedagogia pela Universidade Federal do Amazonas (UFAM). Graduada em Licenciatura em Pedagogia pela Universidade Federal do Amazonas (UFAM). Graduada em Teologia pela Universidade Santa Úrsula (USU). Tem experiência na área de Educação, dialogando com a nova Sociologia da Infância e Antropologia que envolvem os temas da infância, criança, cultura, produções culturais infantis e educação escolar na fronteira amazônica. Atualmente exerce função de professora no Instituto Natureza e Cultura UFAM/BC, INCBC.

NUNES, Rafael Jeremias De Aquino: Discente do Curso de Enfermagem da Faculdade Evolução Alto Oeste Potiguar (FACEP). Bolsista voluntário do Projeto de Pesquisa Intitulado: Estilo de vida na terceira idade: um estudo no sertão nordestino. Publicou como autor, o artigo "Participação popular: uma estratégia de controle na saúde", em conjunto com alunos do curso de Enfermagem da FACEP.

OLIVEIRA JUNIOR, Victor Hugo De: Graduando em Licenciatura Plena em Ciências Naturais - Biologia pela Universidade do Estado do Pará (UEPA). Possui experiências na docência e em estágios extracurriculares, focando no treinamento de competências e habilidades para o ensino de Biologia na educação básica.

OLIVEIRA, José Damião Souza De: Mestre em Ensino de Ciências Naturais e Matemática pela Universidade Federal do Rio Grande do Norte (UFRN). Possui graduação em Licenciatura Plena em Matemática pela Universidade Federal do Rio Grande do Norte (UFRN). Atualmente é professor efetivo da rede estadual do ensino básico do Rio Grande do Norte. Professor Supervisor do Programa Institucional de Bolsas de Iniciação à Docência (PIBID-Matemática UFRN). Tem experiência na área de Educação com ênfase em Ensino de Matemática, atuando principalmente nos seguintes temas: História da Matemática, Tecnologia da Informação e Comunicação e Geometria do Compasso.

PEREIRA, Nathalia Lima: Graduada em Enfermagem pela Universidade Federal do Rio Grande do Sul (UFRS). Residente de Enfermagem na Atenção Básica da Residência Integrada em Saúde da Escola de Saúde Pública (ESP) RS. 
RODRIGUES, Wivina Dayane Do Nascimento: Mestranda do Curso de Ciências da Educação pela Faculdade do Estado do Maranhão (FACEM). Especialista em Língua Brasileira de Sinais (Libras) pela Faculdade do Complexo Educacional Santo André (FACESA). Especialista em Psicopedagogia Clínica, Institucional e Hospitalar pela Faculdade do Complexo Educacional Santo André (FACESA). Especialista em Alfabetização e Letramento, Especialista em Educação Infantil e Anos iniciais; Especialista em Educação Especial, todos pela Faculdade Venda Nova do Imigrante (FAVENI/ES). Graduada em Pedagogia pela Faculdade Integrada do Brasil (FAIBRA). Tem mais de 08 anos de experiência na docência.

SALVI, Luciana Rita Bellincanta: Mestra em Educação pela Universidade Federal da Fronteira Sul (UFFS) - Chapecó. Especialista em Educação Infantil e Séries Iniciais pelo Instituto Brasileiro de Pós-Graduação e Extensão (Curitiba/PR). Especialista em Coordenação Pedagógica pela Universidade Federal de Santa Catarina Florianópolis/SC. Graduada em Pedagogia com habilitação em Educação Infantil e Séries Iniciais pela Universidade do Contestado (UNC) - Concórdia/SC. Aluna do curso de Especialização em Gestão Escolar: Coordenação, Direção e Supervisão Escolar pela Universidade Federal da Fronteira Sul (UFFS) - Erechim/RS. Membro do Grupo de Pesquisa Espaço, Tempo e Educação (GPETE) vinculado a UFFS; Membro do Grupo de Pesquisa Escola de Vigotski (GEPEVI) vinculado a UFFS; Atualmente é Especialista em Educação (Orientadora Educacional), na Escola Básica Municipal Santa Cruz; Atua com: Coordenação Pedagógica; Educação Infantil; Estudos em Paulo Freire aplicados a Infância; Projetos Educacionais Interdisciplinares; Formação de Professores; Currículo, Literatura Infantil e Musicalização.

SANTOS, Ana Paula Araújo Silva Dos: Graduanda em Licenciatura Plena em Ciências Naturais - Biologia pela Universidade do Estado do Pará (UEPA). Trabalhou como Monitora Bolsista do Centro de Ciências e Planetário do Pará. Atuou como Professora na Equipe de Extensão Cursinho Alternativo da Universidade do Estado do Pará (UEPA). Participou do Programa Institucional de Bolsas de Iniciação Científica do Instituto Evandro Chagas. Atua em ações voluntárias no Sinapsys Multidisciplinar e no Laboratório de Neurofisiologia Eduardo Osvaldo Cruz. Tem experiência na área de Biologia Geral, com ênfase em Divulgação Científica, Ensino de Biologia, Neurociências e Virologia. Atualmente, dedica-se ao estudo e integra ações e grupos de pesquisa relacionados às Neurociências, Saúde Mental e Emocional e à Formação de Professores.

SILVA, Anailde Varela Da: Especialista em Educação Ludopedagógica pela Faculdade do Vale Elivira Dayrell/MG. Especialista em Língua Brasileira de Sinais (Libras) pela Faculdade do Vale Elivira Dayrell/MG. Especialista em Educação Infantil pela Universidade Federal do Rio Grande do Norte (UFRN). Graduada em Licenciatura em Pedagogia pela Universidade Federal do Rio Grande do Norte (UFRN). Professora Aposentada da Educação Básica do município de Macau/RN; Professora da Educação Básica do município de Guamaré/RN.

SILVA, Beatriz de Melo: Graduanda do curso de Psicologia pela Universidade Federal do Rio Grande do Norte (UFRN). Técnica em Informática pelo Instituto Federal de Educação, Ciência e Tecnologia (IFRN). Tem grande interesse na área social, nos processos e desenvolvimento humano. 
SILVA, Edna de Almeida Lima: Mestranda em Ciências da Educação pela Absoulute Christian University. Especialista em Aprendizagem e Autoria em Educação Infantil e Ensino Fundamental pela Universidade Estadual do Maranhão (UEMA). Graduada em Pedagogia pelo Instituto de Ensino Superior de São Paulo Faculdade Reunida (FAR). Possui Magistério pelo Centro de Referência para Formação do Magistério Graça Aranha. Tem experiência em gestão escolar no período de 2012 à 2016 na Escola Rosa Rodrigues da Silva. Participou de vários Congressos Nacionais na área de educação. Possui publicações de artigos na área de educação. Atualmente é professora há 18 anos na Escola Rosa Rodrigues da Silva.

SILVA, Gracielle Angeline Tavares Da: Doutora em Produtos Naturais e Sintéticos Bioativos (UFPB). Mestra em Produtos Naturais e Sintéticos Bioativos (UFPB). Especialista em Auditoria em Sistemas de Saúde pela Universidade Estácio de Sá (Rio de Janeiro/RJ). Graduada em Farmácia pela Universidade Federal da Paraíba. Possui habilitação em Análises Clínicas (UFPB). Atualmente é concluinte do Curso de Licenciatura em Letras Língua Portuguesa pela Universidade Federal da Paraíba (UFPB). Atua como pesquisadora no campo da literatura e de práticas de ensino de Língua Portuguesa. Recentemente participou como membro do projeto Residência Pedagógica, implementado pela CAPES (edital $n^{\circ}$ 6/2018), que integra a Política Nacional de Formação de Professores.

SILVA, Rafael Tavares Silveira: Mestre em Enfermagem pela Universidade Federal do Rio Grande do Norte (UFRN). Especialista em Gestão em Saúde pela Universidade Federal do Rio Grande do Norte (UFRN). Especialista em Dermatologia em Enfermagem pela Faculdade Integrada de Patos (FIP). Enfermeiro graduado pela Universidade Federal do Rio Grande do Norte (UFRN). Coordenador do Curso de Graduação em Enfermagem da Faculdade Evolução Alto Oeste Potiguar (FACEP). Professor dos Cursos de Graduação em Enfermagem e de Graduação em Psicologia da Faculdade Evolução Alto Oeste Potiguar (FACEP). Professor Substituto do Curso de Graduação e Licenciatura em Enfermagem da Universidade Estadual do Rio Grande do Norte (UERN) Campus Maria Elisa de Albuquerque Maia (CAPF).

SILVEIRA, Francineide Roseno Da Silva: Especialista em Educação Especial e Inclusiva pela Faculdade Venda Nova do Imigrante (FAVENI). Especialista em Práticas Educativas do Ensino Médio em Artes pela FAL. Especialista em Ensino de Arte na Escola pela Universidade do Estado do Rio Grande do Norte (UFRN). Graduada em Licenciada em Pedagogia pela Universidade do Estado do Rio Grande do Norte (UFRN). Graduada em licenciatura em Educação Física pela Universidade do Estado do Rio Grande do Norte (UFRN). Graduada em Licenciatura em Artes Visuais pelo Centro Universitário Claretiano. Professora do Ensino Fundamental anos Finais, atuante como Professora Auxiliar de Educação Especial da rede pública.

SILVEIRA, Jessica Regina Gomes Paiva Da: Especialista em Atendimento Educacional Especializado pela Faculdade Maciço de Baturité (FMB). Licenciada em Pedagogia pelo Instituto de Educação de Pesqueira/PE (IESP). Professora da Educação Básica do município de Guamaré/RN.

SOUZA, Emilene Costa De: Especialista em Metodologia do Ensino da História e Geografia pelo Centro Universitário Internacional (UNINTER). Especialista 
em Educação Ambiental pela Faculdade São Luís/SP. Licenciada em Geografia pela Universidade Federal do Rio Grande do Norte (UFRN). Professora da Educação Básica dos municípios de Guamaré/RN e Pendências/RN.

SOUZA, Josenildo Gomes De Oliveira: Especialista em Ensino de Matemática pela Universidade Estadual Vale do Acaraú/CE (UVA). Graduado em Licenciatura em Matemática pela Universidade Federal do Rio Grande do Norte (UFRN).

TEMOTEO, Marlice Lígia Martins: Especialista em Meio Ambiente e Sustentabilidade pela Faculdade do Vale Elvira Dayrell (FAVED). Especialista em Metodologia do Ensino de Biologia Faculdade de Educação e Tecnologia da Região Missioneira (FETREMIS). Licenciada em Ciências Biológicas pela Universidade Federal do Rio Grande do Norte (UFRN). Professora da Rede Privada do município de $\mathrm{Macau} / \mathrm{RN}$.

TOLEDO, Bruno De Souza: Doutorando do curso de Sistemas de Informação e Gestão do Conhecimento pela Universidade FUMEC (Fundação Mineira De Educação E Cultura). Mestre em Sistemas de Informação e Gestão do Conhecimento pela Universidade FUMEC (Fundação Mineira De Educação E Cultura). Especialista em Gestão de Tecnologia da Informação pela Faculdade Venda Nova do Imigrante (FAVENI). Especialista em Administração Pública e Finanças pela Faculdade Venda Nova do Imigrante (FAVENI). Especialista em Informática em Educação pela Universidade Federal de Lavras (UFLA). Bacharel em Ciência da Computação pela Universidade Vale do Rio Doce. Licenciado em Formação de Docente para Educação Básica em Matemática pela Faculdade Educacional da Lapa. Possui Licenciatura em Matemática pela Faculdade Capixaba de Nova Venécia. Tem experiência na área de Ciência da Computação e Administração atuando com Linguagens de Programação, Sistemas Operacionais, Informática na Educação, Gerência de Projetos, Empreendedorismo e Metodologia Científica. Ministrou a disciplina de Metodologia Científica no Programa de Pós-Graduação Stricto Sensu Nível Mestrado em Educação Agrícola (PPGEA) da Universidade Rural do Rio de Janeiro (UFRRJ) no ano de 2017. Professor efetivo de Informática no Instituto Federal de Educação, Ciência e Tecnologia de Minas Gerais (IFMG).

TOLEDO, Marcos Vinícius De Souza: Doutorando em Sistemas de Informação e Gestão do Conhecimento pela Universidade Fundação Municipal para Educação Comunitária (FUMEC). Mestre em Sistemas de Informação e Gestão do Conhecimento pela Universidade Fundação Municipal para Educação Comunitária (FUMEC). Especialista em Gestão Pública e Finanças pela Faculdade Venda Nova do Imigrante (FAVENI). Especialista em Informática em Educação pela Universidade Federal de Lavras (UFLA). Licenciado em Matemática pela Faculdade Capixaba de Nova Venécia. Bacharel em Ciência da Computação pela Universidade Vale do Rio Doce (UniVale). Foi coordenador de Curso Técnico em Informática (2014-2017) no IFMG - Campus Avançado de Ponte Nova. Tem experiência nas áreas de Ciência da Computação e Administração, com ênfase nas seguintes áreas: Engenharia de Software, Redes de Computadores, Banco de Dados, Gerência de Projetos, Softwares Aplicativos, Computadores e Sociedade, Informática em Educação, Gestão da Informação e Gestão e Empreendedorismo. Professor efetivo do Ensino Básico, Técnico e Tecnológico do Instituto Federal de Minas Gerais (IFMG). 
VENTURIERI, Bianca: Doutora em Educação para Ciências pela Universidade Estadual Paulista (UNESP). Mestra em Teoria e Pesquisa do Comportamento pela Universidade Federal do Pará (UFPA). Possui graduação em Licenciatura em Ciências Biológicas pela Universidade Federal de Pernambuco (UFPE) e graduação em Bacharelado em Ciências Biológicas pela Universidade Federal de Pernambuco (UFPE). Professora efetiva dos cursos de Ciências Naturais da UEPA, desenvolvendo atividade docente no Centro de Ciências e Planetário do Pará, Grupo de Pesquisa, Ciência, Tecnologia, Meio Ambiente e Educação Não Formal. Tem experiência na Formação de Professores em Ciências, Ensino de Ciências e Metodologia de Pesquisa, Inclusão e Tecnologias Educacionais.

VIANA, Karla Tatiane: Graduada em Enfermagem pela Universidade Federal do Rio Grande do Sul (UFRGS). Residente de Enfermagem na Atenção Básica da Residência Integrada em Saúde da Escola de Saúde Pública (ESP). 